\title{
AVALIAÇÃO DE ALTERAÇÕES EM REDES DE DRENAGEM DE MICROBACIAS COMO SUBSÍDIO AO ZONEAMENTO GEOAMBIENTAL DE BACIAS HIDROGRÁFICAS: APLICAÇÃO NA BACIA HIDROGRÁFICA DO RIO CAPIVARI - SP
}

VOLUME I

Eduardo Goulart Collares

Tese apresentada à Escola de Engenharia de São Carlos, da Universidade de São Paulo, como parte dos requisitos para obtenção do título de Doutor em Geotecnia

ORIENTADOR: Prof. Dr. José Eduardo Rodrigues

São Carlos

2000 


\section{SUMÁRIO}

\section{VOLUME I}

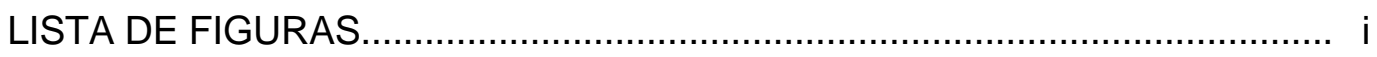

LISTA DE TABELAS .......................................................................... vi

LISTA DE ABREVIATURAS E SIGLAS........................................................ vii

LISTA DE SÍMBOLOS............................................................................... ix

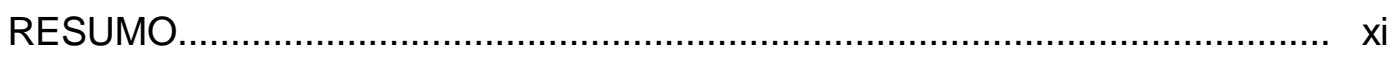

ABSTRACT

1 - INTRODUÇÃO

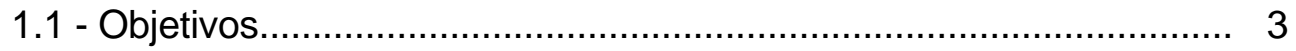

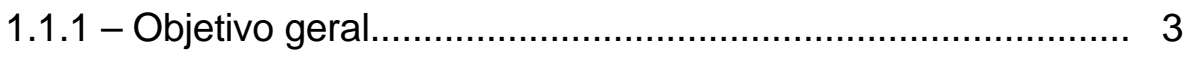

1.1.2 - Objetivos específicos....................................................... 3

1.2 - Localização da área de aplicação da proposta metodológica .......... 4

\section{2 - BACIA HIDROGRÁFICA COMO UNIDADE DE PLANEJAMENTO}

(UMA REVISÃO)

2.1 - Evolução da política ambiental brasileira........................................ 5

2.2 - A bacia hidrográfica como limite territorial para planejamento

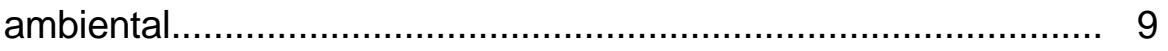

2.3 - Condicionantes das alterações ambientais em bacias

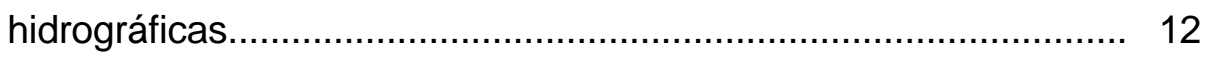

2.3.1 - Conceituação de alteração ambiental................................. 12

2.3.2 - Atividades modificadoras do meio e impactos decorrentes.. 13

2.3.2.1 - Atividade agropecuária............................................ 15

2.3.2.2 - Ocupação urbana.................................................. 16

2.3.2.3 - Disposição de resíduos urbanos............................. 18

2.3.2.4 - Minerações.......................................................... 21

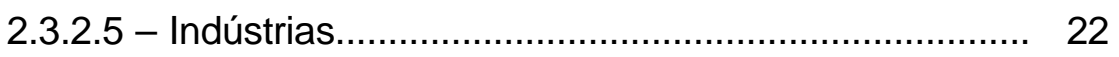

2.3.3 - O planejamento como prevenção às alterações ambientais 23

2.4 - Técnicas de geoprocessamento e análises estatísticas utilizadas em bacias hidrográficas............................................................. 24 
3.1 - Aspectos sócio-econômicos.

3.2 - Aspectos fisiográficos e geológicos.............................................. 33

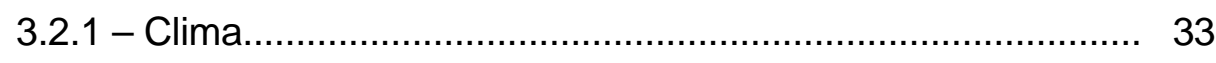

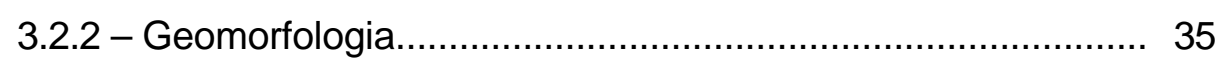

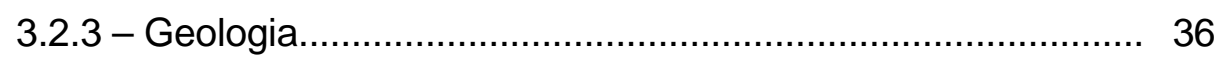

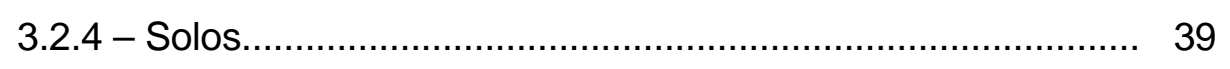

3.2.5 - Aspectos da qualidade das águas..................................... 41

\section{4 - LEVANTAMENTO DE CARACTERÍSTICAS DE USO E OCUPAÇÃO DO} TERRENO E ATIVIDADES ANTRÓPICAS ............................................... 47

4.1 - Considerações iniciais.............................................................. 47

4.2 - Obtenção do mapa de uso e ocupação.......................................... 48

4.2.1 - Processamento de imagem de satélite............................... 48

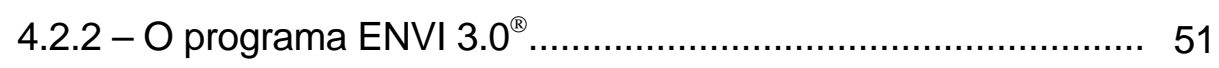

4.2.3 - Processamento das imagens da bacia do rio Capivari........ 52

4.2.3.1 - Georreferenciamento.............................................. 53

4.2.3.2 - Aplicação de realce............................................... 55

4.2.3.3 - Classificação..................................................... 58

4.2.3.4 - Refinamento da classificação.................................. 62

4.2.3.5 - Construção do mosaico e delimitação da bacia....... 66

4.3 - Levantamento das atividades modificadoras do meio físico............. 67

4.3.1 - Levantamento dos dados existentes................................... 67

4.3.2 - Levantamento de campo.................................................... 70

4.3.3 - Elaboração do banco de dados georreferenciado................ 71

4.4 - Análise temporal de intervenções antrópicas.................................... 75

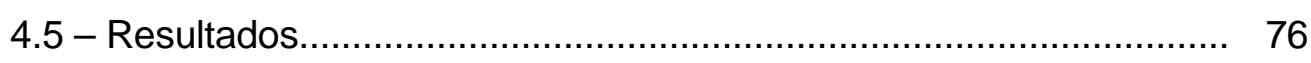

4.6 - Conclusões parciais ................................................................... 82

4.6.1 - Quanto ao processamento das imagens de satélite e obtenção do mapa de uso e ocupação................................. 82

4.6.2 - Quanto ao levantamento pontual das atividades modificadoras do meio físico................................................. 83

4.6.3 - Avaliação das alterações no meio físico............................... 84 
MICROBACIAS

5.1 - Considerações iniciais.

5.2 - Análise morfométrica de bacias hidrográficas (uma revisão). 87

5.3 - Descrição das variáveis morfométricas........................................... 92

5.4 - Levantamento e processamento das informações........................... 101

5.4.1 - Obtenção das redes de drenagem..................................... 102

5.3.2 - Digitalização e processamento dos dados........................... 105

5.5 - Análise das alterações nas microbacias......................................... 109

5.5.1 - Análise estatística multivariada........................................... 109

5.5.1.1 - Análise discriminante............................................. 110

5.5.1.2 - Análise de agrupamento........................................ 113

5.5.2 - Resultados e discussões................................................ 113

5.6 - Conclusões parciais.................................................................. 121

5.6.1 - Quanto à obtenção e processamento da rede de drenagem 121

5.6.2 - Quanto à análise morfométrica........................................... 122

\section{6 - AVALIAÇÕES DOS PARÂMETROS MORFOMÉTRICOS E DAS}

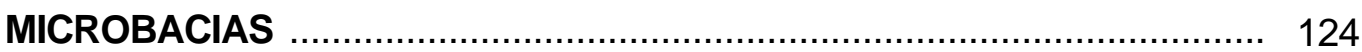

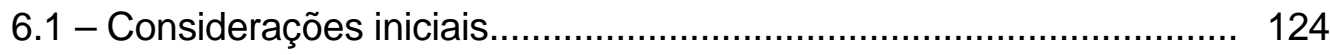

6.2 - Definição de faixas de distribuição para as variáveis morfométricas 125

6.2.1 - Índice de circularidade (Ic) ............................................. 126

6.2.2 - Relação de relevo (Rr)................................................... 127

6.2.3 - Índice de sinuosidade (Si) .............................................. 128

6.2.4 - Densidade de drenagem (Dd).......................................... 129

6.2.5 - Densidade hidrográfica (Dh)............................................ 130

6.2.6 - Coeficiente de manutenção $(\mathrm{Cm})$....................................... 131

6.2.7 - Extensão do percurso superficial (Eps).............................. 132

6.2.8 - Textura topográfica $(\mathrm{Tt})$.................................................. 133

6.2.9 - Razão de bifurcação entre canais de primeira e Segunda ordens (Rb1-2) ........................................................... 134

6.2.10 - Razão de comprimento médio entre canais de segunda e primeira ordens (RIm2-1) ............................................. 135

6.3 - Avaliação das variáveis morfológicas............................................ 136

6.3.1 - Relação entre variáveis morfológicas................................... 136

6.3.2 - Relações entre as variáveis morfológicas e a litologia....... 139 
6.3.3 - Influência das variáveis morfológicas na avaliação das alterações das microbacias..

6.4 - Avaliação das variáveis da rede de drenagem.

6.4.1 - Relação entre as variáveis da rede de drenagem e variáveis morfológicas.

6.4.2 - Relação entre variáveis da rede de drenagem e a litologia.. 146

6.4.3 - Relação entre variáveis da rede de drenagem e suas taxas de variação (\%) no período entre 1972 e 1995. 150

6.4.4 - Relações entre taxas de variação de variáveis da rede de drenagem e características de uso e ocupação.

6.4.5 - Influência das variáveis da rede de drenagem na avaliação das alterações das microbacias.

6.5 - Avaliação das microbacias com base na configuração das redes de drenagem e características de uso e ocupação 163

7 - CONCLUSÕES 170

7.1 - Quanto ao uso das técnicas e aplicativos de geoprocessamento.... 170

7.2 - Quanto à análise temporal de alterações em componentes da paisagem.

7.3 - Quanto ao uso de variáveis morfométricas como indicadores de alterações em bacias hidrográficas.

7.4 - Quanto às alterações verificadas na bacia hidrográfica do rio Capivari e classificação de suas microbacias...

\section{VOLUME II}

APÊNDICE 1: dados gerais das microbacias

APÊNDICE 2: dados morfométricos temporais das microbacias

APÉNDICE 3: atividades modificadoras do meio físico na bacia do rio Capivari APÊNDICE 4: dados estatísticos das variáveis morfométricas 


\section{LISTA DE FIGURAS}

Figura 01: Localização da bacia do rio Capivari.......................................... 4

Figura 02: Alterações provocadas por atividades antrópicas em bacias hidrográficas (modificado de Pires \& Santos, 1995)....................... 14

Figura 03: Esquema do método de Hrkal \& Trouillard (1994)......................... 28

Figura 04: Mapa pluviométrico da bacia do rio Capivari (adaptado de DAEE,

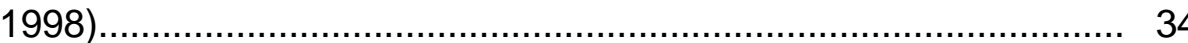

Figura 05: Precipitações médias mensais na bacia do rio Capivari (adaptado de CBH-PCJ, 1996)

Figura 06: Precipitação média acumulada na bacia do rio Capivari (adaptado de CBH-PCJ, 1996)

Figura 07: Mapa geomorfológico da bacia do rio Capivari - escala original 1:500.000 (adaptado de Pires Neto, 1996).

Figura 08: Mapa de substrato rochoso da bacia do rio Capivari (adaptado de Maniakas, 1986; IG, 1993; UNESP, 1986 e DNPM/CPRM, 1984)... 37

Figura 09: Mapa pedológico da bacia do rio Capivari - escala original 1:500.000 (adaptado de Kertzman et al, 1991)

Figura 10: Carta de susceptibilidade à erosão da bacia do rio Capivari escala original 1:500.000 (adaptado de Kertzman et al, 1991)

Figura 11: Carga poluidora orgânica na bacia do rio Capivari em 1995 (adaptado de CBH-PCJ, 1996)

Figura 12: Esquema adotado no processamento das imagens de satélite. 53

Figura 13: Layout da janela de inserção de pontos do ENVI $3.0^{\circledR}$ e o RMS Error.

Figura 14: Utilização do recurso link do programa ENVI 3.0. 56

Figura 15: Utilização do recurso de contraste interativo do ENVI 3.0, através da manipulação dos histogramas de tons de cinza dos pixels em diferentes bandas espectrais

Figura 16: Diagramas de dispersão n-dimensionais do programa ENVI 3.0.... 59

Figura 17: Aparência das amostras de treinamento das classes de uso e ocupação da bacia do rio Capivari na composição de bandas 4-53 (observar áreas demarcadas com o quadrado vermelho).

Figura 18: Layout do aplicativo Classedit mostrando a imagem de satétite ao fundo (bandas 4-5-3) e a classe Hortifruti sobreposta. 
Figura 19: Delimitação da classe Centro Urbano com o uso do aplicativo classedit......

Figura 20: Imagem de satélite Landsat-TM (bandas 4-5-3) da bacia do rio Capivari.

Figura 21: Mapa de uso e ocupação da bacia hidrográfica do rio Capivari.......

Figura 22: Sequência dos procedimentos adotados para a obtenção do banco de dados georreferenciado com as atividades modificadoras do meio.

Figura 23: Mapa das atividades modificadoras do meio físico da bacia do Capivari.....

Figura 24: Sequência dos procedimentos adotada na análise temporal das intervenções antrópicas.

Figura 25: Classificação das microbacias da bacia do rio Capivari por predominância do tipo de uso e ocupação.

Figura 26: Áreas urbanizadas e rodovias na bacia do rio Capivari em 1972 e 1995.

Figura 27: Represas e áreas alteradas por minerações e/ou disposição de resíduos na bacia do rio Capivari em 1972.

Figura 28: Represas e áreas alteradas por minerações e/ou disposição de resíduos na bacia do rio Capivari em 1995.

Figura 29: Microbacias da bacia do rio Capivari com as maiores áreas ocupadas por atividades de mineração e disposição de resíduos.... 80

Figura 30: Microbacias com as maiores áreas ocupadas por represas. 81

Figura 31: Esquema com a sequência dos procedimentos adotados na análise morfométrica das microbacias.

Figura 32: Redes de drenagens traçadas para a microbacia B51 com base em fotografias aéreas nas escalas 1:60.000 e 1:25.000.

Figura 33: Matriz de correlação entre variáveis com dados das microbacias da bacia do rio Capivari das fotografias aéreas de 1972 e $1995 \ldots . . .114$

Figura 34: Matriz de correlação considerando a taxa de variações das variáveis das microbacias da bacia do rio Capivari no período entre 1972 e 1995

Figura 35: Histogramas de frequência e testes gráficos de normalidade para as variáveis Dd e Dh, em 1972 e 1995

Figura 36: Dendrograma obtido para as 65 microbacias da bacia do rio 
Capivari considerando a taxa de variação das variáveis $\mathrm{Dr}$ e $\mathrm{Dh}$ entre 1972 e 1995.

Figura 37: Mapa com a classificação das microbacias quanto ao grau de alteração entre 1972 e 1995 (análise de agrupamento).

Figura 38: Valores da variável índice de circularidade (Ic) das microbacias da bacia do rio Capivari.

Figura 39: Valores da variável relação de relevo $(\mathrm{Rr})$ das microbacias da bacia do rio Capivari

Figura 40: Valores da variável índice de sinuosidade (Si) das microbacias da bacia do rio Capivari.

Figura 41: Valores da variável densidade de drenagem (Dd) das microbacias da bacia do rio Capivari.

Figura 42: Valores da variável densidade hidrográfica (Dh) das microbacias da bacia do rio Capivari

Figura 43: Valores da variável coeficiente de manutenção $(\mathrm{Cm})$ das microbacias da bacia do rio Capivari....

Figura 44: Valores da variável extensão do percurso superficial (Eps) das microbacias da bacia do rio Capivari.

Figura 45: Valores da variável textura topográfica $(\mathrm{Tt})$ das microbacias da bacia do rio Capivari.

Figura 46: Valores da variável razão de bifurcação entre os canais de primeira e segunda ordens (Rb1-2) das microbacias da bacia do rio Capivari

Figura 47: Valores da variável razão de comprimento médio entre os canais de segunda e de primeira ordens (RIm2-1) das microbacias da bacia do rio Capivari.

Figura 48: Matriz gráfica com dados morfológicos das 64 microbacias da bacia do rio Capivari.

Figura 49: Relação entre área e relação de relevo para as 64 microbacias da bacia do rio Capivari.

Figura 50: Relação entre comprimento do canal principal e índice de sinuosidade para as 64 microbacias da bacia do rio Capivari.

Figura 51: Relação entre ordem do canal principal e índice de sinuosidade para as 64 microbacias da bacia do rio Capivari.

Figura 52: Matriz gráfica com dados morfológicos e do substrato rochoso das 
64 microbacias da bacia do rio Capivari 139

Figura 53: Relação entre microbacias areníticas e o índice de circularidade.... 140

Figura 54: Relação entre microbacias do Embasamento e a relação de relevo 141

Figura 55: Relação entre microbacias areníticas e o índice de sinuosidade..... 141

Figura 56: Relação entre microbacias do Embasamento e o índice de sinuosidade.

Figura 57: Matriz gráfica com dados morfológicos e da rede de drenagem...... 144

Figura 58: Relação entre área e densidade de drenagem.............................. 144

Figura 59: Relação entre relação de relevo e densidade de drenagem........... 145

Figura 60: Relação entre razão de bifurcação (Rb1-2) e razão de comprimento médio (RIm2-1) para as 64 microbacias da bacia do rio Capivari

Figura 61: Matriz gráfica com dados da rede de drenagem e do substrato rochoso das 64 microbacias da bacia do rio Capivari.

Figura 62: Relação entre microbacias areníticas e a densidade de drenagem. 147

Figura 63: Relação entre microbacias do Embasamento e a densidade de drenagem.

Figura 64: Relação entre microbacias areníticas e a densidade Hidrográfica.. 148

Figura 65: Relação entre microbacias do Embasamento e a densidade Hidrográfica.

Figura 66: Relação entre microbacias do Embasamento e a razão de bifurcação.

Figura 67: Matriz gráfica com variáveis da rede de drenagem e taxas de variação das variáveis morfométricas no período entre 1972 e 1995

Figura 68: Relação entre densidade de drenagem e sua taxa de variação (\%) no período entre 1972 e 1995

Figura 69: Relação entre densidade Hidrográfica e sua taxa de variação (\%) no período entre 1972 e 1995

Figura 70: Relação entre taxas de variação (\%) de densidade de drenagem e densidade Hidrográfica, no período entre 1972 e 1995.

Figura 71: Relação entre área da microbacia e taxa de variação de Rb1-2 (\%) no período entre 1972 e 1995

Figura 72: Relação entre ordem da microbacia e taxa de variação de Rb1-2 
(\%) no período entre 1972 e 1995

Figura 73: Relação entre densidade de drenagem e taxa de variação de Rb12 (\%) no período entre 1972 e 1995.

Figura 74: Relação entre densidade hidrográfica e taxa de variação de Rb1-2 (\%) no período entre 1972 e 1995

Figura 75: Relação entre taxas de variação (\%) de razão de bifurcação e razão de comprimento médio, no período entre 1972 e 1995.

Figura 76: Relação entre microbacias urbanas e taxa de variação de Dd (\%) no período entre 1972 e 1995

Figura 77: Relação entre microbacias urbanas e taxa de variação de Dh (\%) no período entre 1972 e 1995

Figura 78: Relação entre microbacias rurais (com predomínio de pastagem) e taxa de variação de Dd (\%) no período entre 1972 e 1995.

Figura 79: Relação entre microbacias rurais (com predomínio de pastagem) e taxa de variação de Dh (\%) no período entre 1972 e 1995.

Figura 80: Relação entre microbacias rurais (com predomínio de cana de açúcar) e taxa de variação de Dd (\%) no período entre 1972 e 1995.

Figura 81: Relação entre microbacias rurais (com predomínio de cana de açúcar) e taxa de variação de Dh (\%) no período entre 1972 e 1995

Figura 82: Mapa com a classificação das microbacias da bacia do rio Capivari quanto às alterações na rede de drenagem. 


\section{LISTA DE TABELAS}

Tabela 01: Efeitos ambientais devido às práticas agrícolas (modificado de Corson, 1993)

Tabela 02: Alterações físicas e químicas decorrentes de intervenções antrópicas sobre o meio físico (modificado de FAO, 1995).

Tabela 03: Problemas gerados devido à disposição inadequada de resíduos (modificado de Cunha \& Consoni, 1995)

Tabela 04: Formas de minerações e impactos decorrentes no município de Campinas - SP (modificado de IG, 1995).

Tabela 05: Metas ambientais para o estudo de impactos em planejamento (adaptado de McDonald \& Brown, 1995).

Tabela 06: Dados demográficos e de infra-estrutura urbana dos municípios integrantes da bacia do rio Capivari (IBGE, 1994).

Tabela 07: Dados agropecuários dos municípios que compõem a bacia do rio Capivari (IBGE, 1994)

Tabela 08: Licenças de implantação (LI) e de funcionamento (LF) de indústrias na bacia do rio Capivari emitidas pela CETESB em 1995 (CBHPCJ, 1996)

Tabela 09: Carga poluidora orgânica dos municípios que compõem a bacia do rio Capivari (adaptado de CBH-PCJ, 1996)

Tabela 10: Cargas orgânicas e inorgânicas geradas nas indústrias instaladas na bacia do rio Capivari (CETESB, 1996).

Tabela 11: Quantidade de resíduos sólidos, por classes, gerada na bacia do rio Capivari (adaptado de CETESB, 1993)

Tabela 12: Quantidade de resíduos sólidos domésticos, por municípios, gerada na bacia do rio Capivari (adaptado de CETESB, 1993).....

Tabela 13: Imagens de satélite Landsat - TM utilizadas para a obtenção do mapa de uso e ocupação da bacia do rio Capivari.

Tabela 14: Tipos de uso e ocupação levantados na bacia do rio Capivari para serem utilizados como amostras de treinamento na classificação supervisionada.

Tabela 15: Dados referentes à extensão das classes de uso e ocupação na bacia do rio Capivari.

Tabela 16: Dados da bacia do rio Capivari referentes à análise temporal 
efetuada por meio do estudo comparativo de fotografias aéreas. 78

Tabela 17: Áreas ocupadas por minerações e/ou disposição de resíduos nas microbacias mais significativas. 81

Tabela 18: Áreas ocupadas por represas nas microbacias mais significativas.... 82

Tabela 19: Aspectos referentes à fotointerpretação que influenciaram no traçado das redes de drenagem.

Tabela 20: Dados morfométricos da microbacia B51 adquiridos com base na interpretação das fotografias aéreas, nas escalas 1:60.000 e 1:25.000.

Tabela 21: Terminologia utilizada para arquivos e "layers" na digitalização da microbacia B51

Tabela 22: Resultados do Passo 1 da análise discriminante, considerando as variáveis $\mathrm{Dd}$, Dh, Rb1-2 e RIm2-1

Tabela 23: Resultados do Passo 2 da análise discriminante, considerando as variáveis Dd e Dh.

Tabela 24: Classificação das microbacias por grau de alteração com base nos grupos obtidos com a análise de agrupamento.

Tabela 25: Resultados da análise discriminante obtidos no programa Statística $5.5^{\circledR}$ para grupos definidos na análise de agrupamento.

Tabela 26: Dados estatísticos básicos e faixas de distribuição para os valores de lc 126

Tabela 27: Dados estatísticos básicos e faixas de distribuição para $\mathrm{Rr}$.

Tabela 28: Dados estatísticos básicos e faixas de distribuição para os valores de Si

Tabela 29: Dados estatísticos básicos e faixas de distribuição para Dd. 129

Tabela 30: Dados estatísticos básicos e faixas de distribuição para Dh. 130

Tabela 31: Dados estatísticos básicos e faixas de distribuição para os valores de $\mathrm{Cm}$

Tabela 32: Dados estatísticos básicos e faixas de distribuição para os valores de Eps. 132

Tabela 33: Dados estatísticos básicos e faixas de distribuição para Tt. 133

Tabela 34: Dados estatísticos básicos e faixas de distribuição para os valores de $\mathrm{Rb} 1-2$

Tabela 35: Dados estatísticos básicos e faixas de distribuição para RIm2-1 


\section{LISTA DE ABREVIATURAS E SIGLAS}

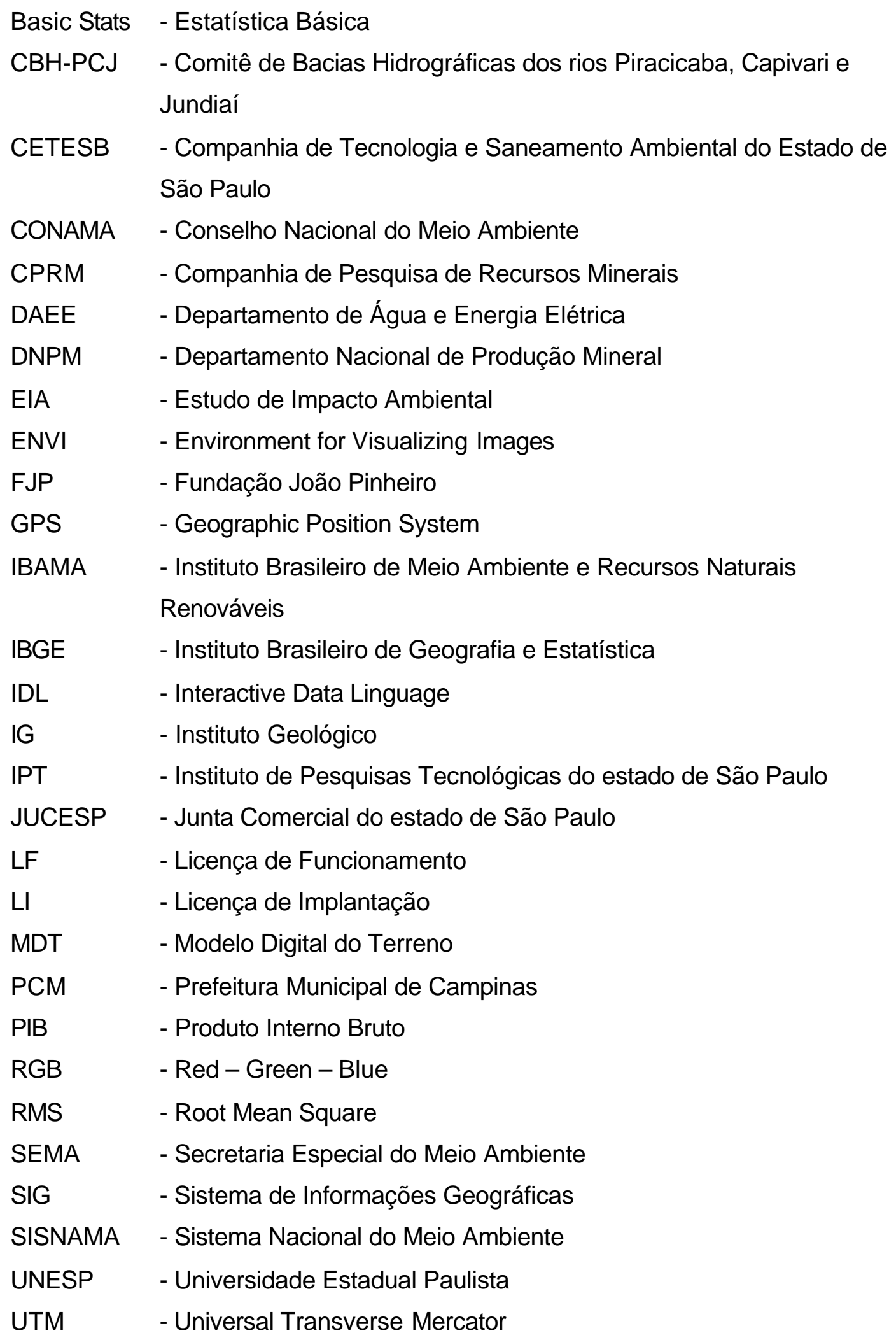




\section{LISTA DE SÍMBOLOS}

\begin{tabular}{|c|c|}
\hline A & - Área \\
\hline ARENITO\% & $\begin{array}{l}\text { - porcentagem de área ocupada em uma microbacia por rochas } \\
\text { sedimentares areníticas }\end{array}$ \\
\hline $\mathrm{Cd}$ & - Cádmio \\
\hline $\mathrm{Cm}$ & - Coeficiente de Manutenção \\
\hline$D^{2}$ & - Distância Generalizada Mahalanobis \\
\hline DBO & - Demanda Bioquímica de Oxigênio \\
\hline $\mathrm{Dd}$ & - Densidade de Drenagem \\
\hline Dh & - Densidade Hidrográfica \\
\hline $\mathrm{dm}$ & - Largura Média \\
\hline$E$ & - Leste \\
\hline EMBASAM\% & - porcentagem de área ocupada em uma microbacia por litologias do \\
\hline & Embasamento Cristalino \\
\hline Eps & - Extensão do Percurso Superficial \\
\hline $\mathrm{Ft}$ & - Fator Topográfico \\
\hline $\mathrm{HO}$ & - Hipótese nula \\
\hline $\mathrm{H} 1$ & - Hipótese alternativa \\
\hline hab & - habitantes \\
\hline $\mathrm{Hm}$ & - Amplitude Altimétrica Máxima \\
\hline Ic & - Índice de Circularidade \\
\hline INTERC\% & $\begin{array}{l}\text { - porcentagem de área ocupada em uma microbacia por rochas } \\
\text { sedimentares intercaladas }\end{array}$ \\
\hline $\mathrm{kg}$ & - quilograma \\
\hline $\mathrm{km}$ & - quilômetro \\
\hline $\mathrm{Km}^{2}$ & - quilômetro quadrado \\
\hline $\mathrm{L}$ & - Maior Comprimento \\
\hline $\mathrm{Li}$ & - Comprimento Total de Canais por Ordem Hierárquica \\
\hline Lmi & - Comprimento Médio por Ordem Hierárquica \\
\hline $\mathrm{L}_{\text {rio }}$ & - Comprimento do Rio Principal \\
\hline $\mathrm{Lt}$ & - Comprimento Total da Rede de Drenagem \\
\hline $\mathrm{L}_{\mathrm{vec}}$ & - Comprimento Vetorial do Rio Principal \\
\hline $\mathrm{m}$ & - metro \\
\hline $\mathrm{mm}$ & - milímetro \\
\hline
\end{tabular}




$\begin{array}{ll}\text { modo Q } & \text { - agrupamento entre casos } \\ \text { modo R } & \text { - agrupamento entre variáveis } \\ \mathrm{N} & \text { - Norte } \\ \mathrm{N} / \mathrm{km}^{2} & \text { - número de canais por quilômetro quadrado } \\ \mathrm{Ni} & \text { - Número Total de Canais por Ordem Hierárquica } \\ \mathrm{P} & \text { - Perímetro } \\ \mathrm{Rb} & \text { - Razão de Bifurcação } \\ \mathrm{Rlm} & \text { - Razão de Comprimento Médio } \\ \mathrm{Rr} & \text { - Relação de Relevo } \\ \mathrm{S} & \text { - Sul } \\ \mathrm{Si} & \text { - Índice de Sinuosidade } \\ \mathrm{Tt} & \text { - Textura Topográfica } \\ \mathrm{V} . \text { limite } & \text { - valor limite } \\ \mathrm{W} & \text { - Oeste } \\ \% & \text { - porcentagem } \\ \alpha & - \text { grau de significância } \\ \mu \mathrm{m} & - \text { micrometros } \\ { }^{0} \mathrm{C} & - \text { graus Celsius }\end{array}$




\section{RESUMO}

Collares, E. G. (2000). Avaliação de alterações em redes de drenagem de microbacias como subsídio ao zoneamento geoambiental de bacias hidrográficas: aplicação na bacia hidrográfica do rio Capivari - SP. São Carlos, 2000. 2v. Tese (Doutorado) - Escola de Engenharia de São Carlos, Universidade de São Paulo.

A rede de drenagem se constitui em importante indicador de alterações ocorridas na composição da paisagem de bacias hidrográficas, seja por mudanças na sua estruturação, forma ou então por ganho ou perda de canais. O objetivo deste trabalho é apresentar e aplicar uma proposta metodológica, com base em análise morfométrica temporal das redes de drenagem de microbacias, visando a avaliação das alterações e o zoneamento regional de uma bacia hidrográfica. A metodologia envolve o uso de imagens de sensoriamento remoto e técnicas de geoprocessamento para a caracterização das atividades antrópicas e levantamento das variáveis morfométricas em duas datas, com um intervalo de 23 anos. A avaliação das alterações e a consequente classificação das microbacias são efetuadas com base em análise estatística multivariada. A proposta foi aplicada na bacia hidrográfica do rio Capivari e os resultados comprovam que ocorreram alterações significativas na composição da rede de drenagem no período de análise. As variáveis morfométricas que mais contribuíram para a avaliação das alterações foram a Densidade de Drenagem e Densidade Hidrográfica. Dentre as microbacias que mais se alteraram estão as urbanas ou em processo de urbanização e, dentre aquelas onde as alterações foram menos pronunciadas estão as microbacias rurais, com predomínio de pastagens e/ou cana de açúcar.

Palavras-chave: análise morfométrica; sensoriamento remoto; fotointerpretação; geoprocessamento; análise estatística multivariada. 


\section{ABSTRACT}

Collares, E. G. (2000). Alteration evaluation in microbasin drainage systems as a subsidy to the geoenvironmental zoning of hydrographic basins: application in the Capivari river hydrographic basin. São Carlos, 2000. 2v. Tese (Doutorado) Escola de Engenharia de São Carlos, Universidade de São Paulo.

The drainage system is an important indicator of the alterations occurred in the composition of the hydrographic basin environment, either due to changes in their structure and shape or due to channel loss and gain. The objective of this project is to present and apply a methodological proposal, based on time morphometric analysis of the microbasin drainage systems, aiming at the alteration evaluation and the regional zoning of a hydrographic basin. The methodology involves the use of remote images and geoprocessing techniques for the characterization of the anthropic activities and the determination of the morphometric variables on two dates, with a 23-year interval. The evaluation of the alterations and the consequent microbasin classification are carried out based on multivariate statistical analysis. The proposal was applied on Capivari river hydrographic basin, and the results prove that there were significative alterations in the drainage system composition in the analyzed period. The morphometric variables which most contributed to the alteration evaluation were the Drainage Density and the Hydrographic Density. Among the microbasins which were most altered there are the urban and under urbanization ones, and among those which had less significative alterations there are the rural microbasins, prevailing the pasture lands and sugar-cane raising.

Keywords: morphometric analysis; remote sensing; photointerpretation; geoprocessing; multivariate statistical analysis. 


\section{1 - INTRODUÇÃO}

A adoção de bacia hidrográfica como unidade de gestão ambiental e planejamento é uma tendência em muitos países e vem ganhando força no Brasil, com a regulamentação da Política Nacional dos Recursos Hídricos (Lei $n^{0}$ 9433, de 1997), que estipula ainda uma atuação descentralizada e participativa nos processos de gestão.

A nova legislação prevê a criação de comitês e agências de bacias e a participação de organizações civis no planejamento ambiental e na elaboração de planos diretores para as bacias hidrográficas. Profissionais ligados às geociências devem ter participação efetiva neste âmbito, para o estabelecimento de diagnóstico geoambiental e proposição de medidas corretivas.

Os limites de atuação para uma unidade de gestão e planejamento ambiental, previstos na legislação, referem-se a bacias de médio e grande portes. Desta forma, considerando-se as condições sócio-econômicas e geoambientais do país, torna-se necessário estabelecer a melhor escala de trabalho para se atingir os objetivos pretendidos e disponibilizar sistemáticas compatíveis com esta escala.

Atualmente, com raras exceções, o diagnóstico ambiental e da qualidade das águas nas bacias hidrográficas é efetuado por órgãos governamentais estaduais, que se limitam à análise da qualidade das águas em um número muito limitado de estações, geralmente no canal principal da bacia. Este procedimento, entretanto, só é apropriado para indicar o enquadramento destes corpos d'água em classes de uso e não permite uma análise das alterações ocorridas no meio físico.

O estabelecimento de um programa de atuação nas unidades de gestão deve, em um primeiro momento, utilizar técnicas de cunho regional, de caráter restritivo, permitindo a discriminação dos setores mais críticos. Ações mais efetivas 
e estudos em escalas maiores deverão ser efetuados, preferencialmente, nestes setores; apenas nestes casos as análises quantitativas, como o monitoramento da qualidade das águas, deverão ser prioritárias.

As análises regionais devem ser encaminhadas visando estabelecer 0 zoneamento da bacia com base nas formas de uso e ocupação e no diagnóstico das alterações provocadas por intervenções antrópicas no meio físico. Imagens de sensoriamento remoto e técnicas de geoprocessamento têm sido utilizadas com propósitos semelhantes em alguns países.

Para o diagnóstico das alterações em escala regional, a rede de drenagem parece ser um bom indicador, uma vez que está vulnerável às diversas formas de atuação antrópica, tais como atividades urbanas, agrícolas, minerárias e obras de infra-estrutura. Mudanças na sua estruturação e forma ou devidas ainda à perda ou surgimento de novos canais podem determinar uma nova dinâmica para 0 escoamento superficial das águas.

Diante dos novos desafios traçados pelas mudanças na política ambiental e da necessidade de desenvolvimento de tecnologias aplicáveis à realidade brasileira, procurou-se estabelecer uma proposta metodológica para subsidiar o zoneamento geoambiental de bacias hidrográficas, em escala regional. O ponto fundamental foi o estabelecimento de um critério para avaliar as alterações ocorridas em componentes da paisagem e, desta forma, promover a compartimentação do terreno (em microbacias) e a identificação daquelas em situações mais críticas.

O trabalho foi estruturado de maneira que cada um dos temas que norteiam a proposta metodológica pudessem ser consultados de forma independente, sem que seja necessário um conhecimento global sobre a proposta para o entendimento e a aplicação das partes. Desta forma, os principais capítulos (4, 5 e 6) foram escritos na forma de artigos técnicos, envolvendo os conhecimentos fundamentais para a compreensão do tema, revisão bibliográfica, metodologia, resultados e discussões. 
No âmbito geral o trabalho apresenta os seguintes tópicos: revisão sobre o uso de bacias hidrográficas como unidade de planejamento (Capítulo 2); caracterização da área de aplicação da metodologia (Capítulo 3); Levantamento de características de uso e ocupação do terreno e atividades antrópicas, com uso de técnicas de geoprocessamento (Capítulo 4); análise temporal de alterações em redes de drenagem de microbacias com base em variáveis morfométricas (Capítulo 5) e avaliação das alterações ocorridas nas microbacias da bacia hidrográfica do rio Capivari e suas relações com características do meio físico e de uso e ocupação (Capítulo 6). Nos apêndices são apresentadas fichas descritivas das microbacias com as redes de drenagem em 1972 e 1995 e dados analíticos referentes à morfometria e características de uso e ocupação.

\section{1 - Objetivos}

\subsection{1 - Objetivo geral}

Apresentar e aplicar uma proposta metodológica, em escala regional, que permita avaliar alterações em componentes da paisagem de bacias hidrográficas e desta forma disponibilizar um instrumento de avaliação geoambiental aos orgãos regionais responsáveis pelo planejamento ambiental das bacias hidrográficas brasileiras.

\subsection{2 - Objetivos específicos}

- Avaliar o uso de técnicas e aplicativos de geoprocessamento no levantamento de características de uso e ocupação do terreno e na obtenção da rede de drenagem de bacias hidrográficas;

- Avaliar as alterações em componentes da paisagem com base em análise temporal de fotografias aéreas;

- Avaliar o uso de variáveis morfométricas como indicadores de alterações em bacias hidrográficas;

- Aplicar a proposta metodológica na bacia hidrográfica do rio Capivari e classificar suas microbacias quanto ao grau de alteração na rede de drenagem. 


\section{2 - Localização da área de aplicação da proposta metodológica}

A bacia do rio Capivari possui uma área de $1580 \mathrm{~km}^{2}$ e está localizada na região centro-leste do estado de São Paulo, com os seguintes limites geográficos aproximados: latitudes $22^{\circ} 50^{\prime} \mathrm{S}$ e $23^{\circ} 20^{\prime}$ e longitudes $46^{\circ} 40^{\prime} \mathrm{W}$ e $47^{\circ} 50^{\prime} \mathrm{W}$ (Figura 01). Possuem sede dos municípios dentro dos limites da bacia as cidades de Campinas, Monte Mor, Louveira, Capivari, Elias Fausto, Rafard e Mombuca. As principais rodovias que cortam a bacia são: Rodovia dos Bandeirantes (SP-348); Rodovia Anhanguera (SP-330) e Rodovia Santos Dumont (SP-300).

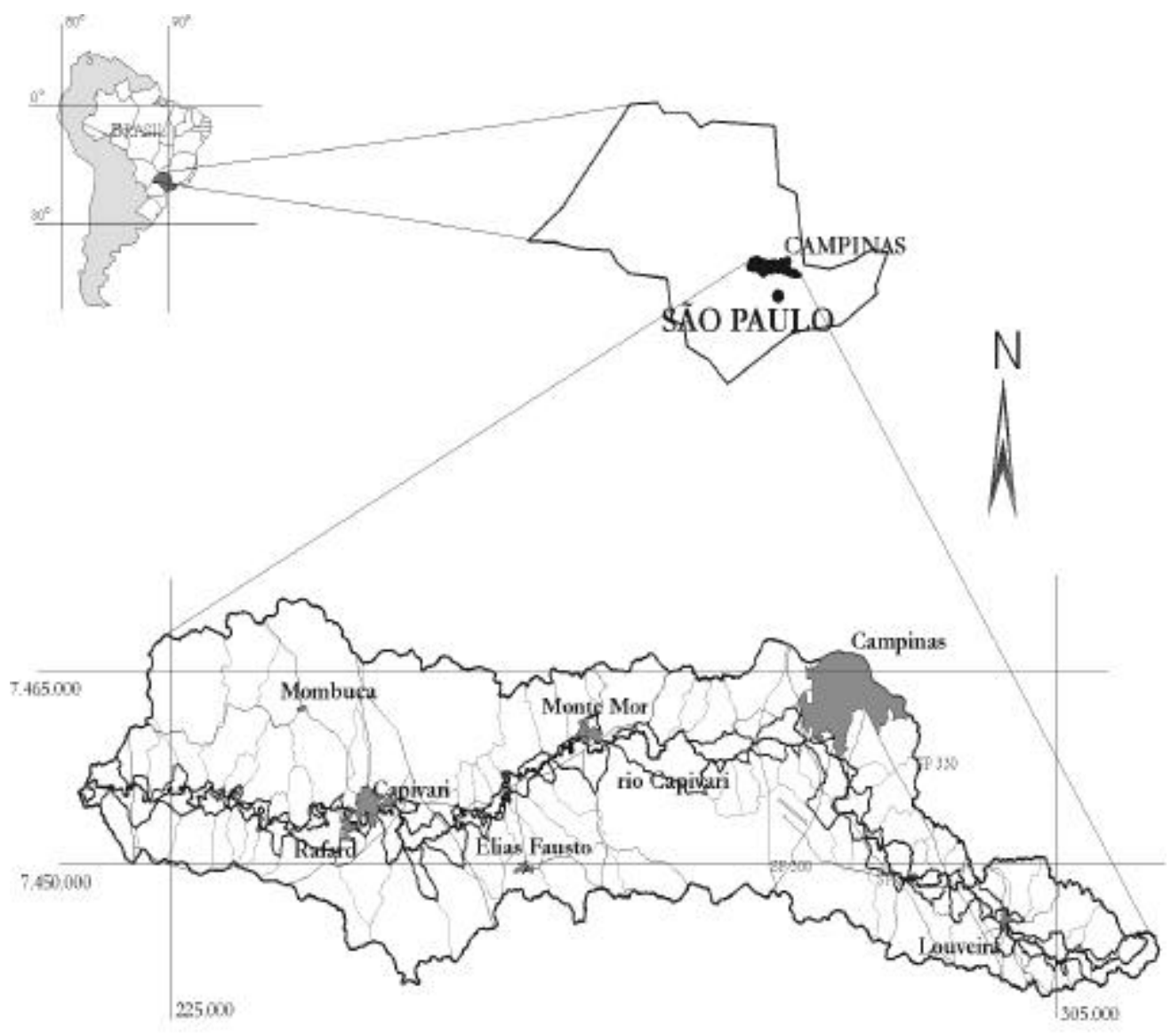

Figura 01: Localização da bacia do rio Capivari. 


\section{2 - BACIA HIDROGRÁFICA COMO UNIDADE DE PLANEJAMENTO (UMA REVISÃO)}

\section{1 - Evolução da política ambiental brasileira}

O marco inicial da implantação da política ambiental no Brasil ocorreu no início da década dos setenta, após a Primeira Conferência das Nações Unidas em Estocolmo, em 1972, e surgiu como resultado de uma pressão exercida por organizações internacionais insatisfeitas com a ausência de política e de legislação de conteúdo especificamente ambiental no país (FJP, 1998).

Como resposta à pressão internacional, o governo brasileiro encaminhou a criação, em 1973, do SEMA - Secretaria Especial de Meio Ambiente - (Decreto $n^{0}$ 73.030). Vale ressaltar que, em termos de aparato legislativo, existem documentos legais mais antigos, tais como o Código Florestal (editado em 1934 e reformulado em 1965), o Código das Águas (1934), o Código de Pesca (1938), o Código de Minas (1940), o Código Nacional de Saúde (1954) e a Política Nacional de Saneamento Básico (1967).

As primeiras medidas advindas com a criação do SEMA ocorreram em 1975 (Decretos-lei 1.413 e 7.389) e se referem à poluição industrial nos grandes centros urbanos e às medidas de prevenção e controle de poluição industrial. Esta fase, entretanto, não se mostrou efetiva na resolução dos problemas ambientais, posto que nesta época o Brasil estava mais preocupado com o desenvolvimento econômico. Um reflexo deste quadro foi sentido com o Decreto 81.107, de 1977, que definiu 0 elenco de atividades consideradas de alto interesse para 0 desenvolvimento e a segurança nacional, onde, dentre elas, se destacou 0 incentivo a algumas indústrias altamente poluidoras. 
A política ambiental começou a tomar novos rumos em 1981, no governo Geisel, com a Lei Nacional do Meio Ambiente (Lei 6.938), que teve por objetivo "a preservação, a melhoria e recuperação da qualidade ambiental propícia à vida, visando assegurar, no país, condições ao desenvolvimento sócio-econômico, aos interesses da segurança nacional e à proteção da dignidade da vida humana". Os princípios abordados na lei são os seguintes:

- ação governamental na manutenção do equilíbrio ecológico, considerando o meio ambiente como um patrimônio público a ser necessariamente assegurado e protegido, tendo em vista o uso coletivo;

- racionalização do uso do solo, do subsolo, da água e do ar;

- planejamento e fiscalização do uso dos recursos ambientais;

- proteção dos ecossistemas, com a preservação de áreas representativas;

- controle e zoneamento das atividades potencial ou efetivamente poluidoras;

- incentivos ao estudo e à pesquisa de tecnologias orientadas para o uso racional e à proteção dos recursos ambientais;

- acompanhamento do estado da qualidade ambiental;

- recuperação de áreas degradadas;

- proteção de áreas ameaçadas de degradação;

- educação ambiental em todos os níveis de ensino, inclusive a educação da comunidade, objetivando capacitá-la para participação ativa na defesa do meio ambiente.

A Lei apresenta ainda uma série de instrumentos que visa contribuir para que se alcance o objetivo proposto. Alguns destes instrumentos, entretanto, até hoje não foram implementados e outros necessitam de ajustes para que atendam, satisfatoriamente, ao objetivo ao qual estão destinados. Os instrumentos são:

- o estabelecimento de padrões de qualidade ambiental;

- o zoneamento ambiental;

- a avaliação de impactos ambientais;

- o licenciamento e a revisão de atividades efetiva ou potencialmente poluidoras;

- os incentivos à produção e instalação de equipamentos e à criação ou absorção de tecnologia, voltados para melhoria da qualidade ambiental;

- a criação de espaços territoriais especialmente protegidos pelo poder público federal, estadual e municipal, tais como áreas de proteção ambiental, de relevante interesse ecológico e reservas extrativistas; 
- o sistema nacional de informações sobre o meio ambiente;

- o cadastro técnico federal de atividades e instrumentos de defesa ambiental;

- as penalidades disciplinares ou compensatórias ao não cumprimento das medidas necessárias à preservação ou correção da degradação ambiental;

- a instituição do relatório de qualidade do meio ambiente a ser divulgado anualmente pelo Instituto Brasileiro do Meio Ambiente e Recursos Naturais Renováveis (IBAMA);

- a garantia da prestação de informações relativas ao meio ambiente, obrigandose o poder público a produzí-las quando inexistentes;

- o cadastro técnico federal de atividades potencialmente poluidoras e/ou utilizadoras dos recursos ambientais.

A promulgação da lei resultou na criação do CONAMA (Conselho Nacional do Meio Ambiente) e na formação do SISNAMA (Sistema Nacional do Meio Ambiente), sendo o primeiro destinado à formulação de diretrizes para a Política Nacional do Meio Ambiente e o outro, constituído por órgãos da União, dos estados, do Distrito Federal e dos municípios e por fundações instituídas pelo poder público, responsável pela proteção e melhoria da qualidade ambiental.

Um ponto fundamental na Lei 6.938, radicalmente contrária à posição da União até então, com respeito às questões ambientais, foi a descentralização da execução da política de controle ambiental, motivando a ação dos estados e municípios e reservando a ela a supervisão e edição de normas gerais da política ambiental, endossando, assim, a idéia da internalização da gestão ambiental pelos governos locais. Com a nova legislação, os estados podem elaborar normas, quando delegado pela União (competência privativa) ou então complementar as normas gerais elaboradas pela União, desde que sejam de caráter mais restritivo. Os municípios, assim como os estados, podem também legislar complementando as normas estabelecidas pelos estados e pela União.

Um importante instrumento em defesa do meio ambiente foi instituído em 1985 (Lei 7.347), autorizando a Ação Civil Pública. Até então, o único meio de ação legal em defesa do meio ambiente era a Ação Popular, que é aquela onde qualquer cidadão pode ser parte legítima para propô-la, desde que assistido por um 
advogado. Os custos processuais e com advogado, entretanto, sempre dificultaram a utilização deste instrumento pelo cidadão comum.

Com o advento da Ação Civil Pública, o Ministério Público apresenta-se como curador do meio ambiente e tem a incumbência de apresentar-se como autor em ações referentes a atos que provoquem a degradação do meio ambiente, e desta forma tornou-se um aliado do cidadão comum preocupado com os danos causados ao meio ambiente.

Em 1988, a Constituição Nacional dedicou um capítulo ao meio ambiente e, pela primeira vez na história do país, fez referência explícita ao direito coletivo a um meio ambiente protegido, atribuindo responsabilidade administrativa, civil ou criminal em relação aos danos a ele causados.

No final da década dos 80 até os dias atuais ocorreram várias mudanças administrativas nos organismos responsáveis por ditar as regras relacionadas ao meio ambiente, provocadas pelos diferentes governos. Em 1989 o presidente José Sarney extinguiu a SEMA e criou o Instituto Brasileiro do Meio ambiente e dos Recursos Naturais Renováveis -IBAMA - (Lei 7.735). Em 1990 o presidente Fernando Collor criou a Secretaria Nacional do Meio Ambiente e alterou as estruturas e atribuições do SISNAMA e do CONAMA (Decreto 99.274). Em 19920 governo Itamar franco elevou a Secretaria Nacional do Meio Ambiente à categoria de Ministério do Meio Ambiente e em 1993 a Ministério do Meio Ambiente e da Amazônia Legal e o presidente Fernando Henrique Cardoso, em 1995, o trasformou em Ministério do Meio Ambiente, Recursos Hídricos e da Amazônia Legal.

Em 1998 a legislação ambiental tomou novo impulso com a promulgação da Lei de Crimes Ambientais (Lei 9.605), onde os princípios assegurados pela Constituição Federal passaram a ser disciplinados e regulamentados. A Lei versa sobre condutas e atividades consideradas lesivas ao meio ambiente que passam a ser punidas civil, administrativa e criminalmente, obrigando o autor da conduta a promover a recuperação do dano e a responder com o pagamento de multa, prestação pecuniária e processo criminal. 
No tocante a medidas que priorizassem o planejamento ambiental, foi sancionada em Janeiro de 1997 a Política Nacional de Recursos Hídricos (Lei 9.433), com base no modelo francês de gestão ambiental. Como princípios básicos da nova Lei estão:

- Adoção da bacia hidrográfica como unidade de planejamento;

- Usos múltiplos da água (todos os setores usuários têm igual acesso ao uso dos recursos hídricos);

- Reconhecimento da água como um bem finito e vulnerável;

- Reconhecimento do valor econômico da água;

- Gestão descentralizada e participativa.

\section{2 - A bacia hidrográfica como limite territorial para planejamento ambiental}

Lanna (1995) propõe a adoção da unidade territorial "bacia hidrográfica" como uma das alternativas para o planejamento e gerenciamento ambiental, destacando algumas vantagens e desvantagens. Dentre as vantagens argumenta que a rede de drenagem de uma bacia pode ser capaz de indicar relações de causa-efeito, particularmente aquelas que envolvem o meio hídrico. Dentre as desvantagens argumenta que nem sempre os limites municipais e estaduais respeitam os divisores da bacia.

Ross \& Del Prette (1998) ressaltam que a gestão ambiental caminha progressivamente para tomar as bacias hidrográficas como unidades de planejamento regional, mas com uma clara ênfase nos recursos hídricos. Advertem, entretanto, sobre a necessidade de uma política que contemple os outros componentes dos recursos naturais (solos, relevo, atmosfera, substrato rochoso, flora e fauna) e os componentes sociais e econômicos, não em termos de bacias hidrográficas, mas também considerando sua inserção regional e sua articulação com os problemas nacionais.

A adoção da bacia hidrográfica como unidade de planejamento não é uma unanimidade entre os países. Segundo Bourlon \& Berthon (1993) vários países da Europa, como por exemplo, Alemanha, Áustria, Bélgica, Dinamarca e Suécia, adotam limites administrativos. Dentre os países que adotam os limites definidos 
por bacias hidrográficas estão França, Espanha, Grécia, Portugal, Reino Unido e os Estados Unidos.

Nos Estados Unidos, apesar haver deste 1965 uma lei que determina a utilização de bacias hidrográficas no planejamento ambiental e dos recursos hídricos, a grande autonomia dos estados, conforme Setti (1996), faz com que ocorram algumas dificuldades para a implantação e execução deste sistema.

$\mathrm{Na}$ França, a legislação que instituiu a adoção da bacia hidrográfica como unidade básica de planejamento e gerenciamento data de 1964. Trata-se de um sistema descentralizado, com a participação da comunidade e que prevê a cobrança pelo uso da água. A organização do sistema se estabelece pela atuação de três entidades, conforme Lanna (1995) e Setti (1996): o Comitê de Bacia, que funciona como um "parlamento" das águas, sendo responsável pelas ações normativas; a Agência de Bacia, que é um organismo público com personalidade civil e autonomia financeira, responsável pela cobrança do uso da água, atribuição de subsídios e empréstimos para realização de obras de interesse comum e contribuição na execução de estudos e pesquisa; e as Comunas e Departamentos, que estabelecem os objetivos de qualidade para os cursos d'água e executam as obras públicas na bacia. Acima destas três entidades está o Estado, por meio de uma coordenação interministerial, que monitora as fontes poluidoras e/ou consumidoras e exerce a tutela sobre as agências e comitês.

O sistema que vem sendo implementado no Brasil desde 1976 por meio de projetos-piloto e que foi posteriormente incorporado pela Política Nacional de Recursos Hídricos (Lei 9.433), tem por base o modelo francês. A primeira experiência, segundo Assis (1996), foi implantada nas bacias do Alto Tietê e Cubatão, no estado de São Paulo.

Assis (1996) e Ross \& Del Prette (1998) destacam outras experiências a partir de 1979, com a participação dos governos federal e estaduais por meio de Comitês Executivos de Estudos Integrados de Bacias de Rios Federais, destacando-se as bacias dos rios Paraíba do Sul (São Paulo, Minas Gerais e Rio de Janeiro), Paranapanema (São Paulo, Paraná), Grande (São Paulo e Minas Gerais), Ribeira do Iguape (São Paulo e Paraná), Jaguari-Piracicaba (São Paulo e 
Minas Gerais), Iguaçu (Paraná e Santa Catarina) e São Francisco (Minas Gerais, Bahia, Sergipe e Pernambuco).

Segundo Assis (1996) estes comitês logo se desgastaram pela ineficiência de suas proposições, devido, principalmente, à falta de poder deliberativo e de recursos financeiros. Entretanto, conforme Ross \& Del Prette (1998), a iniciativa foi importante por estabelecer um modelo de macrozoneamento para as bacias hidrográficas brasileiras.

O primeiro grande passo para instituir uma política efetiva de recursos hídricos utilizando-se de bacias hidrográficas como unidade de planejamento surgiu no estado de São Paulo em 1987, quando começou a ser formulado o Plano Estadual de Recursos Hídricos, promulgado como lei em 1991. Pela nova lei ficaram estabelecidos os seguintes pontos: adoção da bacia hidrográfica como unidade físico-territorial de planejamento e gerenciamento; gerenciamento descentralizado, participativo e integrado dos recursos hídricos; e cobrança pelo uso da água. Para servir de experiência piloto em suas disposições transitórias estabeleceu-se dois Comitês de Bacias em regiões diferenciadas e críticas: um para as bacias do Alto Tietê e Baixada Santista e outro para as bacias dos rios Piracicaba, Capivari e Jundiaí (Assis, 1996).

O comitê das bacias dos rios Piracicaba, Capivari e Jundiaí teve como ponto de apoio a Consórcio Intermunicipal da Bacia do Piracicaba-Capivari, estabelecido em 1989. Segundo Ross \& Del Prette (1998) a criação deste consórcio foi um exemplo pioneiro no Brasil, mas já é prática comum no gerenciamento de bacias hidrográficas na Europa, Japão e Estados Unidos. O consórcio foi criado com os seguintes objetivos: representar o conjunto de municípios em assuntos de interesse comum; melhorar e controlar as condições de saneamento e uso das águas; promover formas articuladas de planejamento do desenvolvimento regional; desenvolver serviços e atividades de interesse dos municípios consorciados.

Com base no modelo francês e na experiência já consumada pela legislação paulista, o governo brasileiro sancionou, em Janeiro de 1997, a Política Nacional de Recurso Hídricos, que prevê o estabelecimento de bacias hidrográficas como unidades de planejamento e gerenciamento e a criação dos seguintes 
organismos: Conselho Nacional de Recursos Hídricos; Comitês de Bacias Hidrográficas; Agências de Bacias e Organizações Civis de Recursos Hídricos. Neste sistema, vale destacar o princípio da gestão descentralizada e participativa, onde as discussões sobre a melhor maneira de lidar com o meio ambiente devem ser geradas pelas próprias localidades.

As experiências de planejamento ambiental já consumadas no Brasil por meio dos comitês de bacias priorizam o desenvolvimento regional e 0 estabelecimento de macrozoneamentos. Partindo desta constatação, Lanna (1995) questiona sobre qual escala de atuação deveria ser a mais adequada para atender aos objetivos e metas pretendidos. Desta maneira, sugere a adoção de, no mínimo, duas escalas: a primeira destinada a tratar da complexidade das inter-relações entre o todo e suas partes, envolvendo toda a superfície territorial da bacia e outra que deve tratar especificamente das partes, considerando as restrições, limitações e demandas impostas pelo todo, devendo ser aplicada em microbacias.

Uma proposta de gestão envolvendo microbacias hidrográficas foi apresentada por Christofoletti (1996) utilizando como áreas-piloto as microbacias do Ribeirão das Furnas e do Ribeirão Claro, localizadas, respectivamente, nos municípios de Araras - SP e Rio Claro - SP. Os procedimentos metodológicos envolvem: a descrição e análise das características morfológicas; a análise dos fluxos de matéria e energia e da dinâmica dos processos atuantes; e a análise da integração entre as características morfológicas e a dinâmica processual.

\section{3 - Condicionantes das alterações ambientais em bacias hidrográficas}

\subsection{1 - Conceituação de alteração ambiental}

São os processos do meio físico e/ ou tecnológicos que promovem dinamismo ao meio ambiente, e que provocam mudanças no mesmo. Segundo Fornasari Filho (1992) os processos, de maneira geral, são descritos por intermédio da análise de fluxos de energia e de matéria que resultam de interações entre seus diversos componentes. 
Os processos do meio físico, decorrem de interações com predominância de componentes abióticos. Para Bitar (1995) e Fornasari Filho (1992), a caracterização destes processos, em termos qualitativos e/ou quantitativos, constitui um alicerce nos planos de estudos ambientais. Os processos tecnológicos estão ligados à interferência do homem no meio ambiente e são acionados pelas atividades modificadoras do meio, tais como ocupações urbanas, implantação de indústrias, cultivo agrícola, obras viárias e minerações.

Às mudanças no meio ambiente decorrentes dos processos, dá-se o nome de alterações ambientais. Dentre estas alterações, aquelas consideradas significativas serão denominadas impactos. Na determinação da significância das alterações, Duinker \& Beanlands (1986) incluem os seguintes aspectos:

- a importância dos atributos ambientais passíveis de serem alterados;

- a distribuição das alterações no tempo e no espaço;

- a magnitude das alterações;

- o grau de confiança nas medições e previsões das alterações.

Alguns autores, como Leopold et al (1971) e Tommasi (1994), incluem no conceito de impacto ambiental um fator de julgamento, qualificando-o em positivo ou negativo. O impacto positivo, ou benéfico, resulta de uma melhoria da qualidade de uma característica ambiental, enquanto o impacto negativo, ou adverso, resulta de um dano à qualidade de uma variável ambiental.

\subsection{2 - Atividades modificadoras do meio e impactos decorrentes}

Dentre as atividades que podem provocar alterações na paisagem ou em características físicas ou químicas das águas em uma bacia hidrográfica, pode-se citar como mais importantes aquelas advindas da agropecuária, da urbanização, da mineração e de indústrias. Estas atividades, bem como algumas das principais alterações delas decorrentes serão descritas neste sub-capítulo.

Pires \& Santos (1995) procuraram esquematizar e montar a cadeia de alterações geradas em decorrência destas atividades, culminando com as 
alterações dos recursos hídricos. Este esquema é apresentado no organograma da Figura 02.

AGRICULTURA - URBANIZAÇÃO - MINERAÇÃO - INDÚSTRIAS

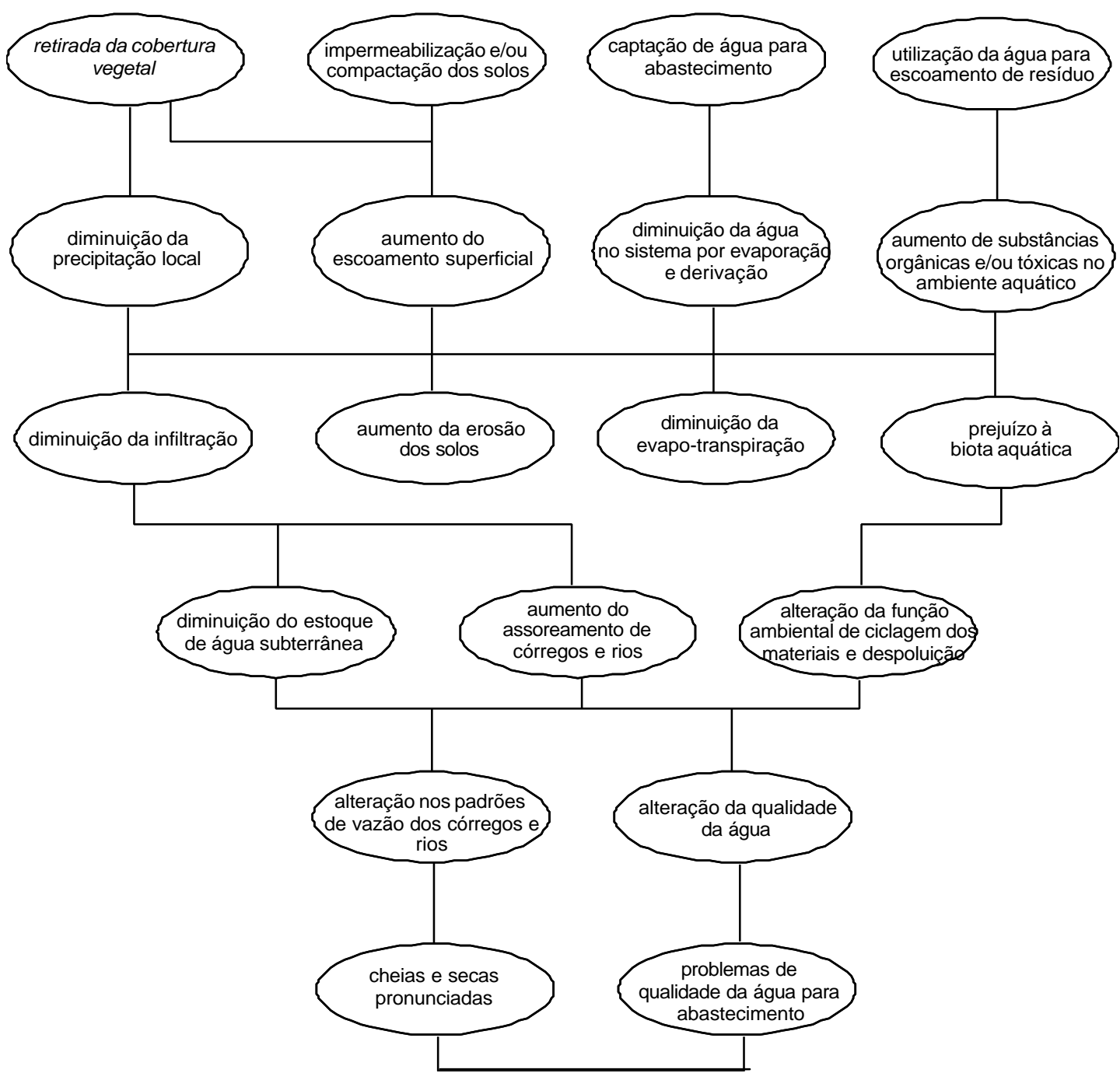

Figura 02: Alterações provocadas por atividades antrópicas em bacias hidrográficas (modificado de Pires \& Santos, 1995). 


\subsubsection{1 - Atividade agropecuária}

O uso de métodos insustentáveis na agricultura está causando sérias degradações e erosão nas terras de cultivo. Segundo Doyle (1991), no início dos anos 80 , estimou-se que 6 toneladas de solo foram perdidos para cada tonelada de grãos produzidos. No mundo são gastos U\$ 24 bilhões, anualmente, na tentativa de controlar a erosão nas plantações.

O crescente uso de fertilizantes químicos, pesticidas e herbicidas está poluindo os aquíferos e ameaçando pessoas e animais. A cada ano há centenas de milhares de acidentes com envenenamento por pesticidas em todo o mundo. Segundo Seager et al (1992), só na Inglaterra e País de Gales foram 2889 só em 1989; em 1988 foram 4141.

Além destes, há outros efeitos secundários relacionados às atividades agroindustriais:

- a irrigação das terras de cultivo responde a $73 \%$ do consumo total de água em todo o mundo; deste total, segundo Corson (1993), apenas 43\% é realmente utilizado, os outros $57 \%$ são perdidos no estoque ou transporte. Este desperdício começa a esgotar o suprimento de água subterrânea e de superfície, e ainda, o uso excessivo elimina os nutrientes do solo e pode fazer com que a terra fique alagada ou demasiamamente salinizada ou alcalinizada.

- o lançamento de estrume de animais, segundo Seager et al (1992), é o principal causador de incidentes em fazendas na Inglaterra e País de Gales.

- a abertura de clareiras para a criação de animais e cultivo é uma causa importante das perdas de florestas. Cerca de 16 milhões de hectares de florestas são desmatados a cada ano para o cultivo ou criação de gado (Corson, 1993).

Os principais efeitos ambientais no solo, água, seres vivos ou outros componentes do meio ambiente, devido às diversas práticas agrícolas podem ser observados na Tabela 01. 
Tabela 01: Efeitos ambientais devido às práticas agrícolas (modificado de Corson, 1993).

\begin{tabular}{|c|c|c|c|c|c|}
\hline $\begin{array}{l}\text { PRÁTICAS } \\
\text { AGRÍCOLAS }\end{array}$ & SOLO & $\begin{array}{l}\text { ÁGUA } \\
\text { SUBTERRÂNEA }\end{array}$ & $\begin{array}{l}\text { ÁGUA DE } \\
\text { SUPERFÍCIE }\end{array}$ & FLORA E FAUNA & $\begin{array}{l}\text { OUTROS: } \\
\text { ar, barulho, } \\
\text { paisagem, } \\
\text { produtos } \\
\text { agrícolas }\end{array}$ \\
\hline $\begin{array}{l}\text { Desenvolvi- } \\
\text { mento da terra: } \\
\text { programas de } \\
\text { consolidação } \\
\text { da terra }\end{array}$ & $\begin{array}{l}\text { direção } \\
\text { inadequada } \\
\text { levando à } \\
\text { degradação } \\
\text { do solo }\end{array}$ & $\begin{array}{l}\text { outra direção da } \\
\text { água } \\
\text { influenciando o } \\
\text { lençol subterrâneo } \\
\text { de água }\end{array}$ & \multirow{4}{*}{$\begin{array}{l}\text { degradação do } \\
\text { solo, } \\
\text { sedimentação, } \\
\text { poluição da água } \\
\text { com partículas do } \\
\text { solo }\end{array}$} & perda de espécie & \multirow{3}{*}{$\begin{array}{l}\quad \text { I } \\
\text { Perda do } \\
\text { ecossistema, } \\
\text { perda da } \\
\text { diversidade } \\
\text { biológica, } \\
\text { degradação da } \\
\text { terra se a } \\
\text { atividade não } \\
\text { for apropriada à } \\
\text { localidade }\end{array}$} \\
\hline $\begin{array}{l}\text { irrigação, } \\
\text { drenagem }\end{array}$ & $\begin{array}{l}\text { sais em } \\
\text { excesso, } \\
\text { represamento } \\
\text { de água }\end{array}$ & $\begin{array}{l}\text { perda da } \\
\text { qualidade (mais } \\
\text { sais), } \\
\text { fornecimento de } \\
\text { água potável } \\
\text { afetado }\end{array}$ & & $\begin{array}{l}\text { ressecamento de } \\
\text { elementos naturais } \\
\text { afetando os } \\
\text { ecossistemas nos } \\
\text { rios }\end{array}$ & \\
\hline lavoura & $\begin{array}{l}\text { erosão } \\
\text { causada pelo } \\
\text { vento e/ou } \\
\text { pela água } \\
\end{array}$ & & & & \\
\hline $\begin{array}{l}\text { mecanização: } \\
\text { equipamentos } \\
\text { grandes ou } \\
\text { pesados }\end{array}$ & $\begin{array}{l}\text { compactação } \\
\text { do solo, } \\
\text { erosão do } \\
\text { solo }\end{array}$ & & & & $\begin{array}{l}\text { gases com a } \\
\text { combustão, } \\
\text { barulho }\end{array}$ \\
\hline $\begin{array}{l}\text { uso de } \\
\text { fertilizante: } \\
\text { - nitrogênio }\end{array}$ & & $\begin{array}{l}\text { lixiviação do } \\
\text { nitrato afetando a } \\
\text { água }\end{array}$ & & & \\
\hline - fosfato & $\begin{array}{l}\text { acúmulo de } \\
\text { metais } \\
\text { pesados (Cd) }\end{array}$ & & $\begin{array}{l}\text { escoamento, } \\
\text { lixiviação ou } \\
\text { descarga direta } \\
\text { levando à } \\
\text { eutrof icação }\end{array}$ & $\begin{array}{l}\text { efeito sobre a } \\
\text { microflora do solo }\end{array}$ & \\
\hline $\begin{array}{l}\text { - esterco, } \\
\text { adubo de } \\
\text { origem animal }\end{array}$ & $\begin{array}{l}\text { excesso: } \\
\text { acúmulo de } \\
\text { fosfato de } \\
\text { cobre } \\
\text { (esterco de } \\
\text { porco) } \\
\end{array}$ & $\begin{array}{l}\text { nitrato, fosfato } \\
\text { (através do uso } \\
\text { excessivo de } \\
\text { esterco como } \\
\text { adubo) }\end{array}$ & & $\begin{array}{l}\text { eutrofização leva: a } \\
\text { excesso de alga e } \\
\text { plantas aquáticas e } \\
\text { diminuição do } \\
\text { oxigênio, afetando } \\
\text { os peixes }\end{array}$ & $\begin{array}{l}\text { mau cheiro, } \\
\text { amônia }\end{array}$ \\
\hline $\begin{array}{l}\text { - adubo com } \\
\text { matéria de } \\
\text { esgoto, } \\
\text { composto }\end{array}$ & $\begin{array}{l}\text { acúmulo de } \\
\text { metais } \\
\text { pesados, } \\
\text { contaminado- } \\
\text { res }\end{array}$ & & & & resíduos \\
\hline $\begin{array}{l}\text { aplicação de } \\
\text { pesticidas }\end{array}$ & $\begin{array}{l}\text { acúmulo de } \\
\text { pesticidas e } \\
\text { produtos } \\
\text { degradantes }\end{array}$ & $\begin{array}{l}\text { lixiviação de } \\
\text { resíduos de } \\
\text { pesticidas móveis } \\
\text { e de produtos } \\
\text { degradantes }\end{array}$ & & $\begin{array}{l}\text { afeta a microflora } \\
\text { do solo; resistência } \\
\text { de algumas ervas } \\
\text { daninhas; } \\
\text { envenenamento: } \\
\text { resistência }\end{array}$ & $\begin{array}{l}\text { evaporação; } \\
\text { acúmulo pela } \\
\text { vaporização, } \\
\text { resíduos }\end{array}$ \\
\hline
\end{tabular}

\subsubsection{2 - Ocupação urbana}

O êxodo rural e o consequente crescimento acelerado das cidades tem provocado, além de uma situação de insalubridade nas áreas marginais, tais como, 
falta de saneamento, água tratada, coleta de lixo, dentre outros fatores essenciais para uma vida aceitável, um alto índice de vulnerabilidade dos terrenos frente às erosões, assoreamentos e acidentes naturais, como escorregamentos.

Segundo Prandini et al (1995), os principais fatores do meio físico que, para um dado clima, condicionam os problemas decorrentes da ocupação são:

- as características geomorfológicas: formas e dinâmica do relevo;

- as características geológicas: tipos litológicos, estruturas, processos geodinâmicos internos e externos;

- as características geotécnicas: características dos terrenos, propriedades dos solos e rochas.

FAO (1995) discorre sobre a influência de intervenções antrópicas no meio físico e as potenciais alterações decorrentes. A Tabela 02 apresenta as alterações físicas e químicas a que são submetidos os constituintes do terreno, em função das diferentes intervenções antrópicas.

Tabela 02: Alterações físicas e químicas decorrentes de intervenções antrópicas sobre o meio físico (modificado de FAO, 1995).

\begin{tabular}{|c|c|c|c|c|c|c|c|}
\hline \multirow[t]{2}{*}{ Atividade } & \multicolumn{4}{|c|}{ Alterações físicas } & \multicolumn{3}{|c|}{ Alterações químicas } \\
\hline & relevo & $\begin{array}{c}\text { cobertura } \\
\text { vegetal }\end{array}$ & solo & $\begin{array}{c}\text { densidade de } \\
\text { drenagem }\end{array}$ & ar & solo & água \\
\hline Urbanização & $x$ & $\mathrm{x}$ & $x$ & $\mathrm{x}$ & & $x$ & $x$ \\
\hline Indústria & $\mathrm{x}$ & & & & $\mathrm{x}$ & $x$ & $x$ \\
\hline Agricultura & $x$ & $\mathrm{x}$ & $\mathrm{x}$ & $x$ & & $x$ & $\mathrm{x}$ \\
\hline Manejo de floresta & & $x$ & & & & $x$ & \\
\hline Turismo & $x$ & $x$ & $\mathrm{x}$ & & & & \\
\hline
\end{tabular}

A ocupação humana, iniciada pelo desmatamento e seguida pelo cultivo da terra, construção de estradas, criação e expansão das vilas e cidades, sobretudo quando efetuada de modo inadequado, constitui, conforme Salomão \& Iwasa (1995), o fator decisivo da origem e aceleração dos processos erosivos. Uma vez ativada, a erosão passa a ser comandada por fatores naturais, tais como, chuva, relevo, solo e cobertura vegetal. 
Kertzman et al (1991), ao estudar as erosões na bacia do médio Tietê, indicam as atividades sócio-econômicas como principais potencializadoras das erosões aceleradas. Os desmatamentos generalizados e as atuações antrópicas no sentido de concentrar o fluxo da água, tais como obras de drenagem, arruamentos e construção de cercas atuam diretamente na proliferação de ravinas e boçorocas. Um dos problemas mais sérios na deflagração de processos erosivos é a expansão de loteamentos em áreas impróprias ao uso do solo.

Uma das maiores consequências da erosão, além das grandes perdas de terrenos, é o assoreamento que provoca nos cursos d'água e reservatórios. 0 principal impacto provocado pelos assoreamentos é o desequilíbrio das condições hidráulicas, o qual gera, por sua vez:

- enchentes;

- perdas da capacidade de armazenamento d'água;

- incremento de poluentes;

- prejuízos para o abastecimento e produção de energia.

Os escorregamentos, responsáveis por milhares de mortes e prejuízos de dezenas de bilhões de dólares a cada ano no mundo, constituem-se em um dos processos mais importantes associados à dinâmica superficial, tanto pelas elevadas frequências com que ocorrem, como pela grande extensão de áreas com risco potencial de ocorrência.

\subsubsection{3 - Disposição de resíduos urbanos}

A disposição de resíduos é um problema que vem sendo encarado com muita seriedade pelos ambientalistas, principalmente pelo alto potencial de cargas tóxicas que lança no meio ambiente. Só nos Estados Unidos estima-se que cada cidadão descarta $1,5 \mathrm{~kg}$ de lixo sólido municipal por dia e no Canadá, 1,9kg. Segundo dados da Organização Panamericana de Saúde (Philippi Jr, 1999) na America Latina e Caribe a quantidade de resíduos domiciliares gerados varia entre 0,3 a 0,6 kg/hab/dia, enquanto a quantidade bruta gerada é em média de 0,7 $\mathrm{kg} / \mathrm{hab} / \mathrm{dia}$. 
A destinação de todo este lixo pode ser a reciclagem, a incineração ou os depósitos de resíduos. Quando opta-se pelos depósitos, a disposição deve ser feita de maneira controlada de forma a evitar a contaminação das águas subterrâneas e de superfície. Zuquette (1991) indica como causas principais da disposição inadequada de resíduos os seguintes pontos:

- falta de conhecimento regional das características do meio físico e do meio ambiente como um todo;

- não caracterização e separação dos tipos de resíduos;

- falta de bases mais reais das normas existentes no Brasil para a escolha dos locais;

- baixo índice de estudos em aterros existentes ou experimentais;

- falta de fiscalização pelos orgãos públicos e punição aos responsáveis pela disposição inadequada dos resíduos.

Segundo Bisordi (1999), a disposição direta no solo é a forma de destinação final de resíduos sólidos mais difundida e utilizada em todo o mundo e em especial em países menos desenvolvidos. No Estado de São Paulo, 56,4 \% dos municípios dispõem lixos domiciliares inadequadamente, $25,4 \%$ de forma controlada e apenas $18,2 \%$ de forma adequada.

A disposição inadequada pode gerar tanto problemas de contaminação, quanto aceleração nos processos do meio físico (Tabela 03). Os principais fatores que conduzem a estes problemas, segundo Cunha \& Consoni (1995), são os seguintes:

- imperfeito conhecimento das características do meio físico (rocha, solo, água, etc.) e dos resíduos alí dispostos, resultando em projeto inadequado;

- negligência no monitoramento das condições ambientais e operacionais do aterro;

- sobrecarga da capacidade inicial do projeto, no intento de prolongar sua utilização.

Além dos problemas construtivos e de localização, os depósitos estão sempre sujeitos aos vários processos físicos, químicos e biológicos que ocorrem entre os resíduos e o meio ambiente. Dentre estes, Campbell (1993) coloca como 
um dos mais importantes os processos anaeróbicos acionados pela matéria orgânica contida nos resíduos. Como consequência destes processos, são produzidos percolantes ricos em amônia e com alto conteúdo orgânico e gases ricos em metano e dióxido de carbono. Tais emissões são poluentes potenciais ou perigosos, se não adequadamente controlados.

Tabela 03: Problemas gerados devido à disposição inadequada de resíduos (modificado de Cunha \& Consoni, 1995).

\begin{tabular}{|c|c|c|}
\hline TIPO & ORIGEM & CAUSAS \\
\hline \multirow{3}{*}{$\begin{array}{l}\text { Contaminação } \\
\text { das águas } \\
\text { subterrâneas }\end{array}$} & $\begin{array}{l}\text {-falha na } \\
\text { impermeab ilização de } \\
\text { base (aterro /lagoa de } \\
\text { tratamento de } \\
\text { chorume }\end{array}$ & $\begin{array}{l}\text { - impermeabilização (solo/manta) incompatível com os } \\
\text { percolados } \\
\text { - má compactação }\end{array}$ \\
\hline & $\begin{array}{l}\text {-recalques } \\
\text { (aterro/lagoa de } \\
\text { tratamento de } \\
\text { chorume) }\end{array}$ & $\begin{array}{l}\text { - solo natural com propriedade inadequada } \\
\text { - recalques devido às alterações (carga, aumento da } \\
\text { umidade, agressão ao solo, etc.) }\end{array}$ \\
\hline & $\begin{array}{l}\text {-elevação do nível } \\
\text { d'água acima da base } \\
\text { do aterro }\end{array}$ & $\begin{array}{l}\text { - dados insuficientes (nível piezométrico, pluviometria, } \\
\text { vazões, etc.) } \\
\text { - mal dimensionamento do sistema de drenagem }\end{array}$ \\
\hline \multirow[t]{2}{*}{$\begin{array}{l}\text { Potencialização } \\
\text { de processos do } \\
\text { meio físico }\end{array}$} & $\begin{array}{l}\text {-escorregamentos e } \\
\text { erosão }\end{array}$ & $\begin{array}{l}\text { - cortes em altos ângulos nas encostas } \\
\text { - cortes contra a foliação ou fraturamentos } \\
\text { - alterações na vegetação marginal } \\
\text { - deficiências de compactação dos aterros e resíduos } \\
\text { dispostos }\end{array}$ \\
\hline & -assoreamentos & $\begin{array}{l}\text {-erosão dos cortes (solo de fácil } \\
\text { alteração/instabilização) } \\
\text { - carreamentos devido à deficiência na drenagem } \\
\text { superficial } \\
\text { - desvegetação/alterações nas áreas marginais }\end{array}$ \\
\hline
\end{tabular}

Embora o risco de contaminação seja o principal problema na disposição de resíduos, existem outros fatores que também contribuem para a degradação ambiental. Dentre eles se incluem:

- impacto visual e estético;

- danos à fauna e à flora;

- doenças em animais e população carente;

- acúmulo de produtos não biodegradáveis no ambiente;

- mal cheiro. 


\subsubsection{4 - Minerações}

Mascarenhas (1989) classifica as fontes de impacto em atividades minerárias conforme o tipo de lavra e o tipo de minério:

A) conforme o tipo de lavra:

- Céu aberto: é o tipo de lavra que gera maior impacto: produz grande quantidade de estéril, além de poeira, ruido, vibrações e poluição das águas.

- Subterrânea: o impacto é menor: o estéril pode ser jogado nas próprias galerias abandonadas, os efluentes líquidos surgentes são pontuais, o mesmo ocorre com a poeira, os ruidos e a vibração.

- Dragagem: é potencialmente poluidora: o revolvimento do leito dos rios e áreas vizinhas provoca turbidez e sólidos em suspensão. Há também poluição química devido à utilização de produtos químicos no beneficiamento (ex: mercúrio e cianeto na mineração de ouro).

B) conforme o tipo de minério:

- Minérios utilizados na construção civil: São geralmente pedreiras localizadas próximas aos centros urbanos: causam problemas principalmente na ocasião das detonações e britagem, acarretando poluição devido ao pó, vibração e ruido.

- Metálicos: geralmente, para obtenção do concentrado, mais de $90 \%$ do run of mine é liberado como rejeito em forma de lama fina, contaminada com reagentes químicos e orgânicos. Muitas vezes liberam também $\mathrm{SO}_{2}$ atmosférico, o que provoca chuvas ácidas.

- Ferrosos: libera, geralmente, grande quantidade de estéril, devido ao decapeamento. O minério é submetido a diversos processos de beneficiamento que geram poluição (pó, ruidos, vibrações, etc). O rejeito é lançado na fase líquida em barragens de decantação.

- Carvão: quando a céu aberto, abrange grandes áreas e causa poluição no ar e água. Quando subterrânea pode liberar efluentes ácidos, gerar combustão e também estar sujeita à subsidência.

IG (1993), ao estudar o meio físico como subsídio ao planejamento territorial do município de Campinas - SP, apresenta os principais tipos e formas de minerações ocorrentes na região bem como os principais impactos gerados (Tabela 04). 
Tabela 04: Formas de minerações e impactos decorrentes no município de Campinas - SP (modificado de IG, 1995)

\begin{tabular}{|c|c|c|}
\hline Bem mineral & Forma de lavra & Principais impactos gerados \\
\hline \multirow[t]{2}{*}{ Argila para cerâmica } & cava seca & $\begin{array}{l}\text { Retirada do solo superficial; desmatamentos; processos } \\
\text { erosivos; assoreamento das drenagens; formação de } \\
\text { cavas abandonadas }\end{array}$ \\
\hline & $\begin{array}{l}\text { Cava submersa } \\
\text { (planícies de inundação) }\end{array}$ & $\begin{array}{l}\text { Comprometimento da vegetação na planície de inundação } \\
\text { ou mata ciliar; formação de lagoas; alteração do perfil } \\
\text { hídrico; assoreamento }\end{array}$ \\
\hline \multirow{3}{*}{$\begin{array}{l}\text { Areia para construção } \\
\text { civil }\end{array}$} & Dragagem no leito do rio & $\begin{array}{l}\text { Aumento da turbidez das águas; erosão nas margens; } \\
\text { comprometimento da mata ciliar devido à disposição dos } \\
\text { estoques de areia }\end{array}$ \\
\hline & $\begin{array}{l}\text { Dragagem nas planícies } \\
\text { de inundação }\end{array}$ & $\begin{array}{l}\text { Comprometimento da vegetação na planície de inundação } \\
\text { ou mata ciliar; formação de lagoas; alteração do perfil } \\
\text { hídrico; assoreamento }\end{array}$ \\
\hline & $\begin{array}{l}\text { Exploração com pá em } \\
\text { aluviões de pequenas } \\
\text { drenagens }\end{array}$ & $\begin{array}{l}\text { Referem-se às atividades precedentes (normalmente } \\
\text { loteamentos) que ocasionam processos erosivos e } \\
\text { assoreamentos nas drenagens }\end{array}$ \\
\hline Brita & $\begin{array}{l}\text { Desmonte em bancadas } \\
\text { com explosivo }\end{array}$ & $\begin{array}{l}\text { Alteração da paisagem devido à desfiguração topográfica e } \\
\text { desmatamento; emissão de pó; vibrações e ruídos devidos } \\
\text { às detonações; praças de lavras abandonadas }\end{array}$ \\
\hline Pedra ornamental & $\begin{array}{l}\text { Desmonte com marretas } \\
\text { ou similares }\end{array}$ & $\begin{array}{l}\text { Comprometimento do patrimônio paisagístico; } \\
\text { desmatamento; processos erosivos; disposição irregular de } \\
\text { rejeitos nas encostas }\end{array}$ \\
\hline Água mineral & Captação superficial & Sem impactos associados \\
\hline Saibro ou cascalho & $\begin{array}{l}\text { Trator ou } \\
\text { retroescavadeira em } \\
\text { encostas ou cortes de } \\
\text { estradas }\end{array}$ & $\begin{array}{l}\text { Alteração da paisagem; desmatamento; instabilização de } \\
\text { encostas e taludes; processos erosivos e assoreamento } \\
\text { das drenagens no entorno; áreas de extração } \\
\text { abandonadas }\end{array}$ \\
\hline
\end{tabular}

\subsubsection{5 - Indústrias}

As indústrias, como atividades produtoras e de transformação, têm a capacidade de lançar na água poluentes que podem ser nocivos á saúde humana ou à sobrevivência de outros seres vivos. Lança desde poluentes orgânicos, como derivados de petróleo, fenóis e detergentes, passando pelos derivados de fertilizantes e agrotóxicos, chegando até os metais pesados. Estes últimos, constituem uma classe de destaque dentre os poluentes, tanto pelo grau de 
periculosidade de alguns dos seus elementos, como é o caso do chumbo, do cromo, do cádmio e do mercúrio, quanto pela sua mobilidade.

\subsection{3 - O planejamento como prevenção às alterações ambientais}

McDonald \& Brown (1995) defendem a utilização do estudo de impacto ambiental (EIA) em termos de planejamento e não apenas na avaliação de impacto ambiental para empreendimentos específicos. Um trabalho com este intuito deverá permitir avaliar o grau de degradação que existe em uma determinada área, devido às atividades existentes e ainda avaliar as suas limitações ambientais no sentido de acomodar novas atividades. Para a efetivação do processo de impacto ambiental no planejamento, os autores definem algumas metas que devem ser incorporadas aos planos. Estas metas estão expostas na Tabela 05.

Tabela 05: Metas ambientais para o estudo de impactos em planejamento (adaptado de McDonald \& Brown, 1995).

\section{Metas quanto aos recursos ambientais}

- controlar a intensidade do uso de recursos ambientais

- conservar o habitat dos animais selvagens e manter a biodiversidade

- estimular a eficiência do uso de energia em transporte, indústria e setores residenciais

- assegurar que a ocupação não utilize áreas destinadas para outros fins

- assegurar que a ocupação não ocorra em terrenos impróprios

\section{Metas quanto à queda da qualidade ambiental}

- assegurar que a capacidade de assimilação de resíduos dos corpos aquáticos e do ar possa conviver com o terreno planejado

- coleta e disposição dos resíduos sólidos e líquidos sem causar a longo prazo contaminação do terreno e da água

- promover mobilidade nas áreas urbanas, mas minimizar os efeitos ambientais adversos da intrusão da infra-estrutura de transporte e movimento do tráfego sobre pessoas

- previnir problemas de poluição em geral

- proteger a saúde humana

Maglio (1991), defende a utilização do estudo de impacto ambiental (EIA) como instrumento de planejamento ambiental no Brasil, aplicando-o na avaliação 
de planos e programas regionais e locais, visando promover o desenvolvimento sustentável. Para que esta questão torne-se realidade, algumas necessidades deverão ser supridas:

- retomada do planejamento físico-territorial urbano, regional e local, considerando a variável ambiental;

- desenvolvimento do zoneamento dos diferentes espaços;

- promoção do planejamento ambiental das bacias hidrográficas.

Pires \& Santos (1995) utilizam uma sistemática de trabalho para o planejamento e gerenciamento de bacias hidrográficas, verificando causas e efeitos das intervenções humanas e traçando diretrizes de desenvolvimento adequadas ao ambiente físico e biológico. A sistemática envolve as seguintes etapas:

- diagnóstico ambiental;

- prognóstico ambiental;

- integração das análises ambiental, política e econômica;

- zoneamento ambiental.

\section{4 - Técnicas de geoprocessamento e análises estatísticas utilizadas em bacias hidrográficas}

Civco et al (1995) destacam que embora a caracterização de bacias hidrográficas não seja uma novidade para cientistas e planejadores, suas possibilidades e aplicações tornaram-se exponencialmente maiores com a evolução dos sistemas de geoprocessamento.

A geração, digitalização e manipulação de dados georeferenciados em sistemas informatizados vêm sendo utilizadas desde a década dos 70 , com o desenvolvimento dos sistemas de informações geográficas (Aronoff, 1989). Na década dos 80, Burrough (1986) estimou que, só nos Estados Unidos haviam, aproximadamente, mil diferentes sistemas de informações geográficas com funções específicas e destinados às mais diversas aplicações cartográficas.

$\mathrm{Na}$ década dos 90, alguns sistemas se despontaram dos demais por atenderem a aplicações mais generalizadas. Câmara (1994) comparou a 
funcionalidade de alguns dos sistemas mais utilizados no mercado brasileiro e mundial, com base nos seguintes instrumentos de geoprocessamento: análise geográfica, processamento digital de imagens, modelagem numérica de terreno, modelagem de redes e produção cartográfica. $O$ autor constatou que a grande maioria apresentava deficiências em pelo menos um dos instrumentos.

Sheng et al (1997) propõem o uso de Sistemas de Informações Geográficas (SIGs) na classificação e avaliação de bacias hidrográficas em países em desenvolvimento e destacam a importância de ferramentas como o Modelo Digital do Terreno (MDT) na obtenção de parâmetros como borda da bacia, elevações e características das encostas e em combinação com outros fatores, como mapa geológico e de solos, para derivar cartas interpretativas. Civco et al (1995) também consideram o MDT importante para a caracterização de bacias e complementam que a sua combinação com outros dados fornece grandes oportunidades para identificar novos parâmetros descritivos.

Muitos autores desenvolveram algorítimos com base em MDT para a extração de redes de drenagem de bacias hidrográficas. Meisels et al (1995) agrupam os procedimentos até então desenvolvidos em três grupos: algorítimos de passo simples; algorítimos de passo duplo e cálculos automáticos da rede de drenagem. Destes, os primeiros a serem desenvolvidos e também os mais deficientes foram os de passo simples, porque além de produzirem canais descontínuos, não são capazes de locar canais onde as concavidades do relevo não estão bem definidas.

Band (1986) desenvolve um algorítimo de passo duplo adicionando operadores para conectar fragmentos de canais separados que permite a extração das redes em sub-bacias de bacias hidrográficas. Band (1989) aprimora esta técnica com o objetivo de produzir mais detalhes e a associa a um SIG, melhorando as funções de armazenamento, manejo e recuperação de atributos da área de drenagem.

Meisels et al (1995) discutem sobre os vários procedimentos utilizados para a extração de redes de drenagem com o uso de MDT e destacam a ocorrência de deficiências técnicas nos mais simplificados e deficiências operacionais nos mais 
complexos. Os autores propõem um método composto por um algorítimo principal, complementado por procedimentos de pré e pós-processamento.

Ferreira (1997) utiliza MDT, em escala regional, para a estimativa de enchentes em bacias hidrográficas onde há escassez de dados hidrológicos. No método apresentado, alguns parâmetros morfométricos são extraídos do MDT e correlacionados com dados fluviométricos. Dentre os parâmetros analisados, a amplitude altimétrica e o desvio padrão das altitudes mostraram-se mais adequados para o estudo das cheias.

Ferreira (1999) utiliza-se de uma técnica de geoprocessamento denominada Modelo Digital das Distâncias Mínimas (MDI), por meio da função de vizinhança extensiva presente em SIGs, para interpretar a variabilidade espacial de parâmetros morfométricos dentro de uma bacia hidrográfica.

Sousa (2000) utiliza técnicas de realce em fotografias aéreas digitalizadas, para testar a viabilidade de se traçar a rede de drenagem de bacias hidrográficas a partir da tela do computador, em detrimento ao processo manual com uso de estereoscópio. Os resultados não produziram o efeito desejado. O autor só recomenda a técnica para bacias com rede de drenagem muito bem definida, preferencialmente com ocorrência sistemática de matas ciliares.

A análise de terreno, com auxílio de sensoriamento remoto e sistemas de informações geográficas, vem se tornando cada dia mais usual, tanto nos órgãos administrativos quantos em empresas privadas e de pesquisa. Saito et al (1994), fizeram um levantamento em 200 agências americanas envolvidas com a qualidade das águas e constataram que mais de um terço destas utilizam algum tipo de SIG.

Ferreira (1996) apresenta aspectos conceituais relacionados à modelagem cartográfica em SIG e suas aplicações para geração de mapas de susceptibilidades. O autor destaca a necessidade de uma discussão multi e interdisciplinar no que se refere aos escores atribuídos a fatores e restrições espaciais. Esta atitude seria fundamental para a confiabilidade dos documentos gerados. 
Jakubauskas et al (1992), pesquisando áreas agrícolas, utilizaram imagens de satélite (Landsat -TM, SPOT multispectral e SPOT pancromática) e um SIG para auxiliar na avaliação de regiões com problemas potenciais de poluição não pontual. O objetivo foi extrair classes de cobertura do terreno que, posteriormente processadas, seriam utilizadas como parâmetro de entrada em um modelo que prevê a magnitude de fontes de poluição agrícola não pontual.

Yang et al (1999) apresentam um sistema de integração entre modelamento da qualidade da água, sensoriamento remoto e SIG e, desta forma, conseguem interpretar a variação espacial da qualidade da água e identificar potenciais fontes de poluição. A sistemática é aplicada em um reservatório localizado na região de foz de uma bacia hidrográfica em Taiwan utilizando imagens SPOT e monitoramento dos seguintes parâmetros de qualidade da água: Temperatura; Oxigênio Dissolvido; Demanda Bioquímica de Oxigênio; Turbidez; Fósforo Total; Nitrogênio Orgânico; Nitrato e pH. Os autores ressaltam que este sistema deverá ser mais prático e poderoso quando estiverem disponíveis imagens de satélite mais sofisticadas, com resolução mais fina, transmissão de dados em tempo mais curto e imagens de menor custo.

Hrkal \& Trouillard (1994) propõem um método para a definição de áreas de risco de poluição em uma bacia hidrográfica de $4900 \mathrm{~km}^{2}$ em Orléans, na França, utilizando um SIG. O método utiliza-se de 4 grupos de informações que dão origem aos mapas básicos: fontes de poluição; condições climáticas; vulnerabilidade e qualidade da água. O produto final é o mapa de risco de poluição crítico e cargas máximas de poluição admissível (Figura 03).

Wranic et al (1994) realizaram uma pesquisa em uma área de aproximadamente $600 \mathrm{Km}^{2}$ envolvendo 3 sub-bacias da bacia hibrográfica de Santa Mônica (Califórnia - Estados Unidos) com o objetivo de indicar cargas e fontes de poluentes, utilizando-se de dados pré-existentes. Os resultados obtidos indicam a carga de poluentes gerada por categoria de uso do terreno.

Lent et al (1998) utilizam análise multivariada para analisar parâmetros hidrológicos, geológicos, geográficos e dados da qualidade da água em microbacias hidrográficas do Estado de Massachusetts - Estados Unidos. As 
análises permitiram classificar as microbacias com características similares quanto aos parâmetros da qualidade da água.

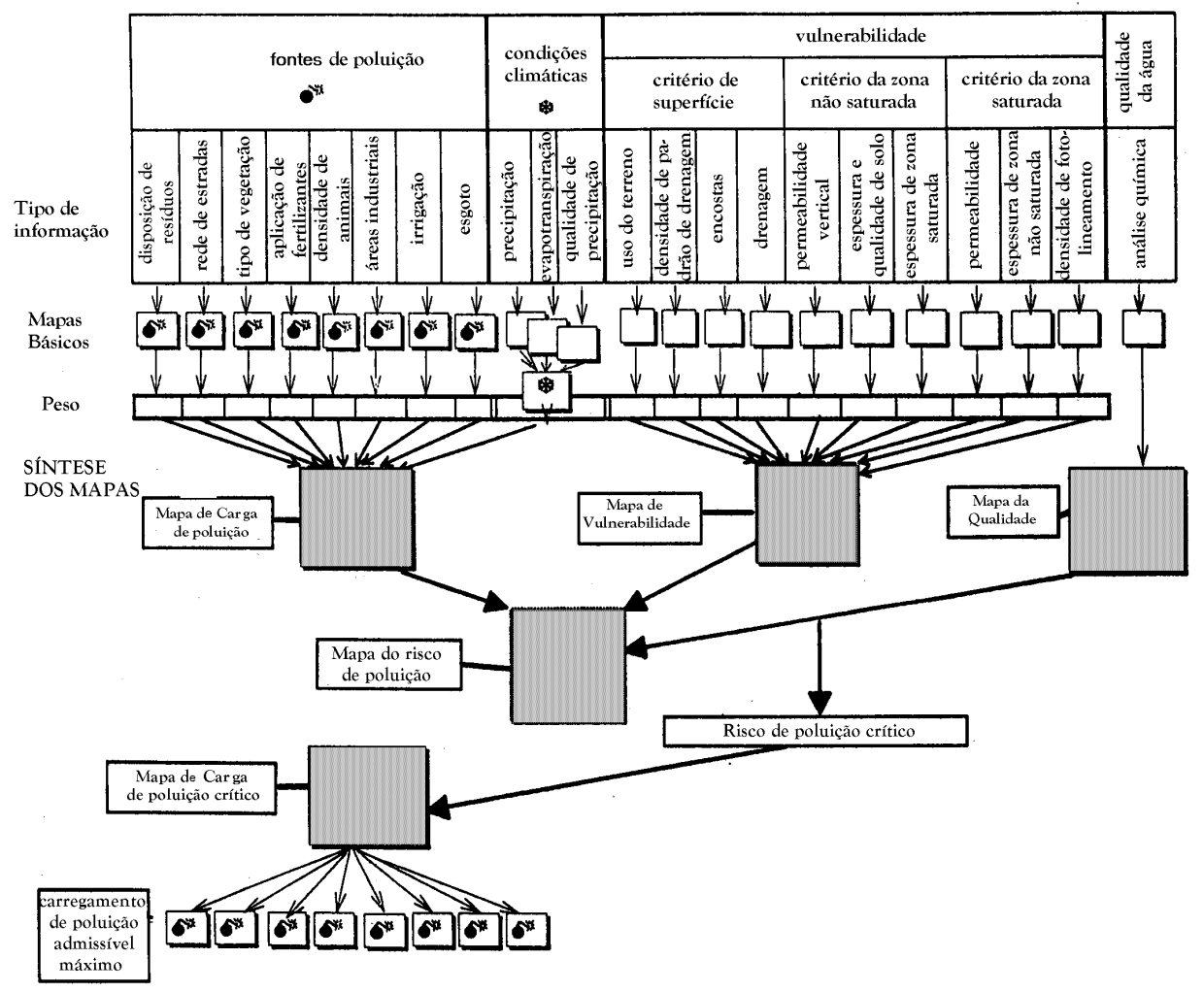

Figura 03: Esquema do método de Hrkal \& Trouillard (1994).

Outros trabalhos, como o de Villalba et al (1995), o de Ramesh et al (1995) e o de Abu-Jaber et al (1997) utilizam-se de análises estatísticas na avaliação de parâmetros fisico-químicos das águas, entretanto, considerando apenas as águas de subsuperfície. Villalba et al (1995) utilizam-se de mapas de contorno, técnicas estatísticas simples e índices de qualidade para indicar a qualidade da água para uso agrícola, industrial e para consumo humano em uma bacia no município de Sevilha na Espanha. O produto final foi um mapa com índices de qualidade global para as águas de subsuperfície.

Ramesh et al (1995) utilizam-se de matrizes de correlação, análise de fatores e mapas de contorno para detectar contaminações em um aquífero na 
cidade de Masdras na Índia, e indicar as prováveis fontes poluidoras. Abu-Jaber et al (1997), com os mesmos objetivos, realizam estudos em aquíferos da Jordânia, utilizando-se de análise das componentes principais e análise de fatores. 


\section{3 - CARACTERIZAÇÃO GERAL DA ÁREA DE ESTUDO}

\section{1 - Aspectos sócio-econômicos}

A bacia do rio Capivari está inserida na região de influência da cidade de Campinas que é considerada a segunda região mais importante do Estado de São Paulo e a terceira do país. Apresenta economia com alto índice de crescimento, motivado, principalmente, pela interiorização do desenvolvimento da Região Metropolitana de São Paulo em direção aos eixos rodoviários que cortam a bacia (Rodovia dos Bandeirantes, Anhanguera e Santos Dumont). Uma comprovação deste fato é o PIB de 24,5 bilhões de dólares, segundo maior do Estado, e a renda per capita de 12 mil dólares (EMPLASA, 1997), que é bem superior à brasileira e a do estado de São Paulo.

Os municípios que possuem sede municipal dentro da bacia são Campinas, Capivari, Elias Fausto, Louveira, Mombuca, Monte Mor e Rafard, compreendendo uma população total de cerca de 1 milhão de habitantes e uma alta taxa de urbanização. Em Campinas a taxa de urbanização chega a 97\%, o que tem motivado, nos últimos anos, a opção de empreendedores e da própria população em instalar-se nas cidades vizinhas, elevando os índices de crescimento destas cidades (Tabela 06). Quanto às atividades econômicas, são substanciais as contribuições das atividades agrárias, industriais e de mineração.

Com relação às atividades agrárias predominam os hortifrutigranjeiros e as lavouras de cana de açúcar. O cultivo de hortifrutigranjeiros ocorre, principalmente, na cabeceira da bacia, onde estão localizadas a cidade de Louveira e a periferia de Jundiaí, e também na periferia de Campinas e de Elias Fausto. Plantações de cana de açúcar predominam do setor central, onde estão as cidades de Monte Mor, Capivari, Rafard e Mombuca, até a foz do rio Capivari. A distribuição das atividades agrárias por município é apresentada na Tabela 07. 
Tabela 06: Dados demográficos e de infra-estrutura urbana dos municípios integrantes da bacia do rio Capivari (IBGE, 1994).

\section{Dados demográficos e de infra-estrutura urbana dos}

municípios da Bacia do Rio Capivari

\begin{tabular}{l|c|c|c|c|c|c|c}
\hline & Campinas & Capivari & $\begin{array}{c}\text { Elias } \\
\text { Fausto }\end{array}$ & Louveira & Mombuca & $\begin{array}{c}\text { Monte } \\
\text { Mor }\end{array}$ & Rafard \\
\hline Área (Km2) & 890 & 319 & 203 & 54 & 136 & 236 & 140 \\
\hline População (hab) & 885700 & 36580 & 12592 & 18065 & 2576 & 29414 & 9238 \\
\hline Taxa de urbanização (\%) & 97,33 & 84,31 & 59,42 & 86,92 & 49,04 & 86,23 & 76,3 \\
\hline $\begin{array}{l}\text { Densidade demo-gráfica } \\
\text { (hab/Km2) }\end{array}$ & 995,17 & 114,67 & 62,03 & 334,54 & 18,94 & 124,64 & 65,99 \\
\hline $\begin{array}{l}\text { Taxa de crescimento } \\
\text { anual (\%) }\end{array}$ & 1,38 & 2,31 & 2,85 & 3,54 & $-0,43$ & 5,14 & 2,35 \\
\hline $\begin{array}{l}\text { Abastecimento de água } \\
\text { (\%)* }\end{array}$ & 96.92 & 94,88 & 93,26 & 71,1 & 73,42 & 92,18 & 98 \\
\hline \begin{tabular}{l} 
Esgoto sanitário (\%)* \\
\hline Coleta de lixo (\%)*
\end{tabular} & 85,39 & 89,54 & 64,36 & 67,49 & 67,72 & 42,72 & 97,64 \\
\hline
\end{tabular}

* Dados de 1991

Tabela 07: Dados agropecuários dos municípios que compõem a bacia do rio Capivari (IBGE, 1994).

\section{Dados agropecuários dos municípios da Bacia do Rio Capivari}

\begin{tabular}{l|l|l|l|l|l|l|l}
\hline & Campinas & Capivari & $\begin{array}{l}\text { Elias } \\
\text { Fausto }\end{array}$ & Louveira & Mombuca & Monte Mor & Rafard \\
\hline Bovinos (cabeças) & 24520 & 4200 & 3600 & 550 & 1123 & 13100 & 2486 \\
\hline Suínos (cabeças) & 11422 & 30900 & 5450 & 5200 & 1288 & 5570 & 1000 \\
\hline $\begin{array}{l}\text { Granjeiro (galos, } \\
\text { galinhas, frangos) }\end{array}$ & 453071 & 305000 & 88700 & 806500 & 493677 & 561592 & 83000 \\
\hline $\begin{array}{l}\text { Lavoura } \\
\text { permanente (\%) }\end{array}$ & 5,8 & 0,1 & 0,6 & 25,4 & 0,2 & 1,3 & 0,05 \\
\hline $\begin{array}{l}\text { Lavoura } \\
\text { temporária (\%) }\end{array}$ & 0,7 & 58,8 & 3,3 & 1,5 & 39,1 & 33,7 & 64,9 \\
\hline $\begin{array}{l}\text { Lavoura total (\%) } \\
\text { Principais culturas } \\
\text { (\% da área total) }\end{array}$ & $\begin{array}{l}\text { café(2\%) } \\
\text { caranja(3\%) }\end{array}$ & cana(57\%) & $\begin{array}{l}\text { milho(2\%) } \\
\text { tomate(1\%) }\end{array}$ & $\begin{array}{l}\text { uva(18\%) } \\
\text { caquí(3\%) }\end{array}$ & $\begin{array}{l}\text { cana(37\%), } \\
\text { milho(2\%) }\end{array}$ & $\begin{array}{l}\text { cana(18\%), } \\
\text { milho(10\%), } \\
\text { batata(3\%) } \\
\text { tomate(2\%) }\end{array}$ & $\begin{array}{l}\text { cana(ho(4\%) } \\
\text { milho(4) }\end{array}$ \\
\hline
\end{tabular}


Atividades industriais ocorrem em todos os municípios da bacia mas são mais representativas no entorno da cidade de Campinas e ao longo dos eixos das rodovias Anhanguera, Bandeirantes e Santos Dumont. Indústrias de grande porte, com mais de mil funcionários (JUCESP, 1998), como Singer, Bosch, Mercedes Benz, Pirelli, Gessi-Lever, Vidrotex, Tetra Pack, além de usinas de álcool, estão localizadas dentro dos limites da bacia.

Indústrias de porte médio, com mais de cem funcionários (JUCESP, 1998), ocorrem nos municípios de Campinas, Monte Mor, Capivari e ao longo das rodovias Anhanguera e Bandeirantes, entretanto, dois polos industriais concentram grande parte delas. O primeiro é próximo ao aeroporto de Viracopos e o outro no município de Vinhedo, às margens da Rodovia Anhanguera.

A cada ano novas empresas têm procurado os municípios que compõem a bacia do rio Capivari para a instalação de suas indústrias. No ano de 1995, a CETESB emitiu 82 licenças de instalação e 88 licenças de funcionamento para indústrias dos mais diversos ramos (Tabela 08).

Tabela 08: Licenças de implantação (LI) e de funcionamento (LF) de indústrias na bacia do rio Capivari emitidas pela CETESB em 1995 (CBH-PCJ, 1996)

\begin{tabular}{c|c|c}
\hline Atividades & LI & LF \\
& & \\
\hline extração e tratamento de minerais & 1 & 0 \\
\hline minerais não metálicos & 7 & 10 \\
\hline metalúrgicas & 10 & 15 \\
\hline mecânicas & 5 & 4 \\
\hline material elétrico e comunicações & 3 & 2 \\
\hline material de transporte & 6 & 5 \\
\hline madeira & 1 & 2 \\
\hline mobiliário & 0 & 1 \\
\hline papel e papelão & 2 & 5 \\
\hline borracha & 2 & 1 \\
\hline couros e peles & 0 & 0 \\
\hline
\end{tabular}

\begin{tabular}{c|c|c}
\hline Atividades & LI & LF \\
& & \\
\hline química & 10 & 13 \\
\hline produtos farmacêuticos e veterinários & 4 & 0 \\
\hline perfumes, sabões e vela & 5 & 6 \\
\hline matérias plásticas & 8 & 7 \\
\hline têxtil & 0 & 1 \\
\hline vestuário, artefatos e tecidos & 1 & 1 \\
\hline produtos alimentares & 3 & 4 \\
\hline bebidas & 1 & 1 \\
\hline fumo & 0 & 0 \\
\hline editorial e gráfica & 6 & 6 \\
\hline outras & 7 & 4 \\
\hline
\end{tabular}


As principais atividades de mineração praticadas na bacia são do tipo argila para cerâmica e areia e brita para a construção civil. As argilas e areias são extraídas, predominantemente, ao longo das margens do rio Capivari ou, eventualmente, de materiais residuais do Subgrupo Itararé. Segundo IG (1993), só no município de Campinas são 77 praças em atividade, a maioria delas ao longo do rio Capivari. As britas são extraídas de pedreiras de diabásio e estão situadas nos municípios de Campinas, Monte Mor e Capivari.

\section{2 - Aspectos fisiográficos e geológicos}

\subsection{1 - Clima}

O clima predominante na bacia do rio Capivari, de acordo com Setzer (1966), é do tipo Cwa (classificação de Koeppen), subtropical, com inverno seco e temperaturas superiores a $22^{0} \mathrm{C}$ no mês mais quente. Na região próxima da cabeceira, onde as altitudes são mais elevadas, o clima é do tipo Cfa e Cfb, sem a ocorrência de estação seca.

A pluviosidade média na bacia varia entre $1100 \mathrm{~mm}$ e $1400 \mathrm{~mm}$ (DAEE,1998). Como pode ser observado no mapa da Figura 04, precipitações médias superiores a $1300 \mathrm{~mm}$ ocorrem na cabeceira da bacia, onde estão as mais altas altitudes e relevo de morros. No entorno da cidade de Campinas e no extremo noroeste da bacia, as precipitações médias variam entre $1200 \mathrm{~mm}$ e $1300 \mathrm{~mm}$. Na região central, onde se localizam as cidades de Capivari, Rafard, Elias Fausto, Monte Mor e Mombuca, as precipitações variam entre 1100 e $1200 \mathrm{~mm}$.

A média histórica de precipitações, com base no período entre 1971 e 1995, indica que os meses com maiores índices pluviométricos são Janeiro e Dezembro, com precipitações em torno de $200 \mathrm{~mm}$ e os mais secos são Julho e agosto, onde as precipitações raramente ultrapassam $50 \mathrm{~mm}$. Em 1995, as precipitações ocorreram bem acima da média, como pode ser observado nas Figuras 05 e 06 . A precipitação acumulada naquele ano foi superior a $1600 \mathrm{~mm}$, consequência, principalmente, das chuvas ocorridas no mês de fevereiro. 


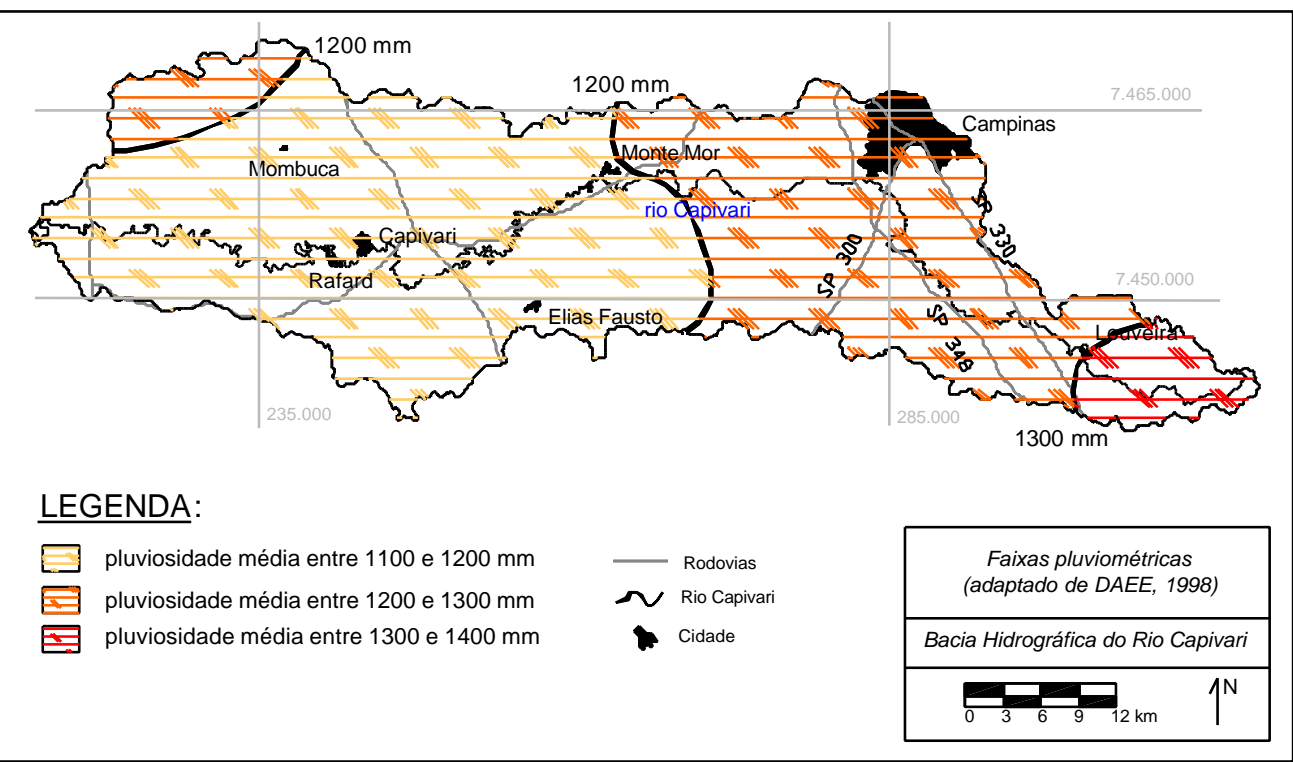

Figura 04: Mapa pluviométrico da bacia do rio Capivari (adaptado de DAEE, 1998)

\section{Precipitação Média Mensal \\ Bacia do Rio Capivari}

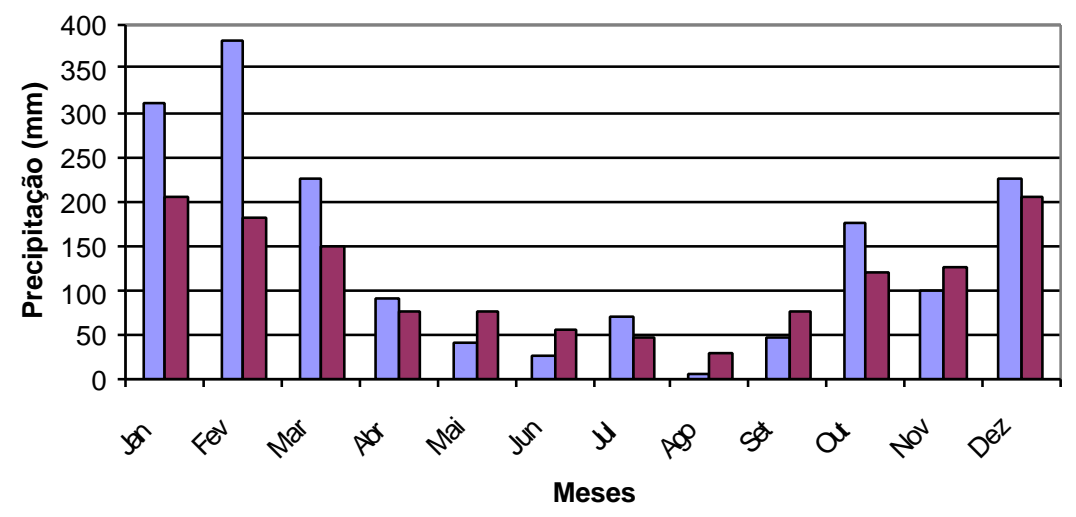

$1995 \square$ Média da Série Histórica - 1971 a 1995

Figura 05: Precipitações médias mensais na bacia do rio Capivari (adaptado de CBH-PCJ, 1996) 


\section{Precipitação Média Acumulada Bacia do Rio}

Capivari

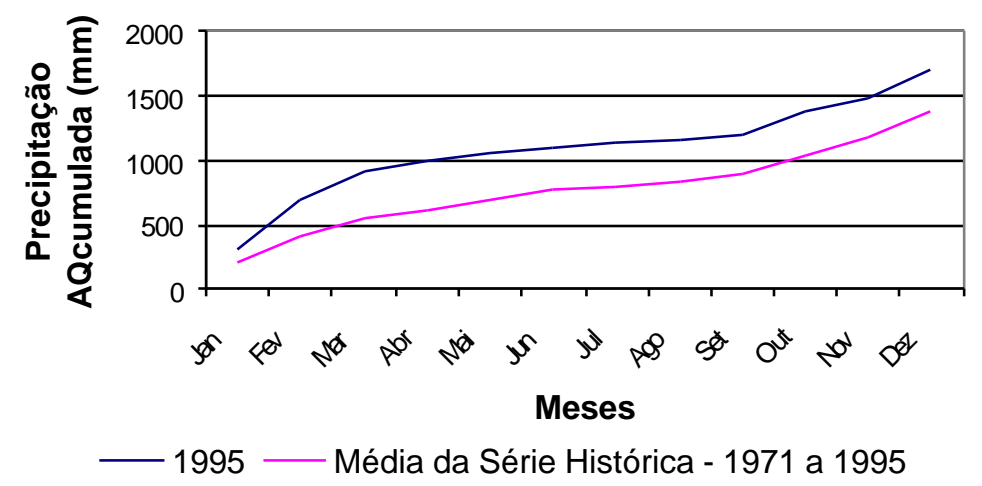

Figura 06: Precipitação média acumulada na bacia do rio Capivari (adaptado de CBH-PCJ, 1996).

\subsection{2 - Geomorfologia}

Conforme o Mapa Geomorfológico Regional do estado de São Paulo (IPT, 1981), escala $1: 1.000 .000$, a área onde está inserida a bacia do rio Capivari é composta, predominantemente, por Colinas Amplas e Médias e Morrotes Alongados Paralelos e Espigões. Na cabeceira, onde o substrato rochoso é composto por rochas do Embasamento Cristalino, ocorre, também, relevo de morros.

Pires Neto (1996), ao efetuar o estudo morfotectônico do Capivari e outras bacias adjacentes, elaborou um mapa geomorfológico, na escala 1:500.000, desta região. Na bacia do rio Capivari foram diferenciados dez tipos de relevo (Figura 07). As formas predominantes, que correspondem a toda a área ocupada pelas litologias da Bacia do Paraná, são relevos de colinas pequenas, médias e amplas, com amplitudes que variam de 20 a 130 metros, comprimento de rampa de 250 a 2500 metros e declividades entre 2 e $18 \%$.

Relevos de morrotes paralelos e dissecados ocorrem no setor leste da bacia e apresentam amplitude de 30 a 140 metros, amplitude de rampa entre 200 e 800 metros e declividades entre 8 e 40\%. Morrotes e morros ocorrem em uma área restrita, próxima à cabeceira do rio Capivari, apresentando amplitude entre 60 e 200 
metros, comprimento de rampa entre 200 e 900 metros e declividades entre 12 e $34 \%$.

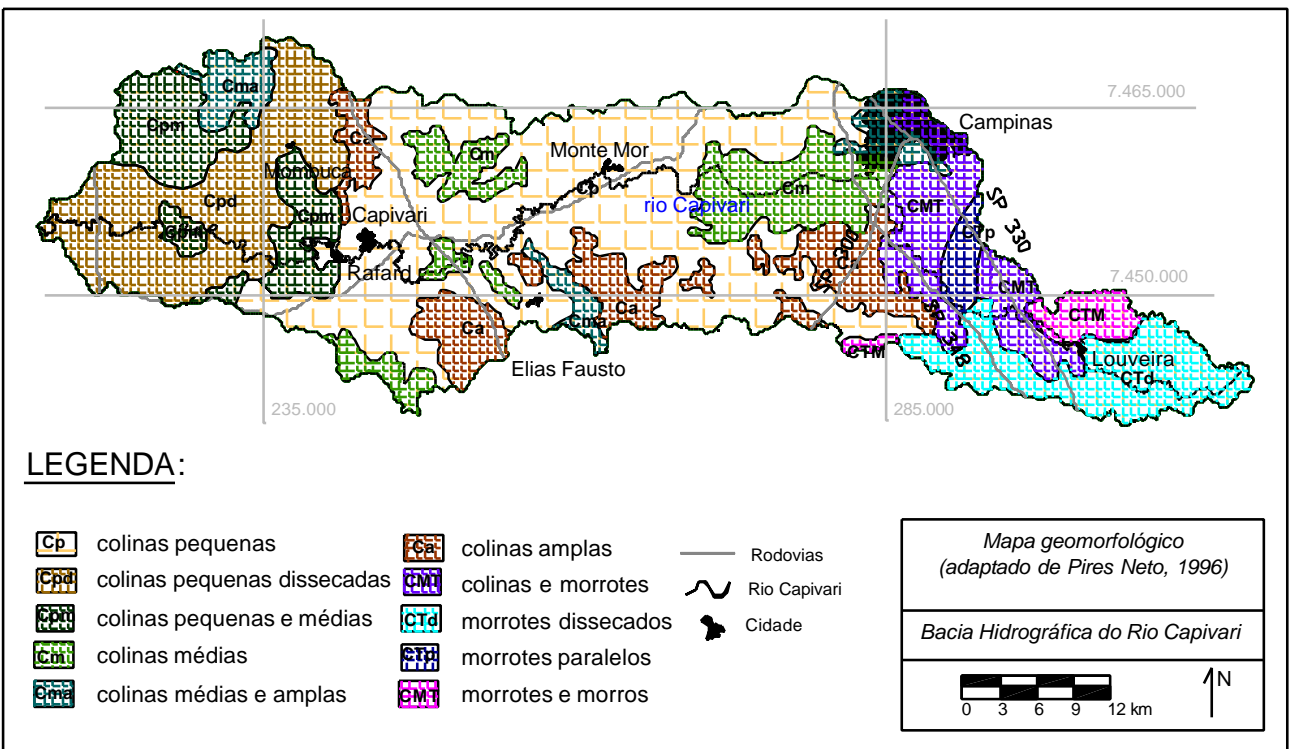

Figura 07: Mapa geomorfológico da bacia do rio Capivari - escala original 1:500.000 (adaptado de Pires Neto, 1996).

\subsection{3 - Geologia}

A geologia regional da área onde está inserida a bacia do rio Capivari é representada por rochas do Embasamento Cristalino, com predomínio de gnaisses e rochas milonitizadas do Complexo Itapira e por Granitos Indiferenciados na porção leste e por rochas sedimentares e intrusivas básicas da Bacia do Paraná na porção central e oeste (WERNICK, 1978, DAEE/UNESP, 1982 e DNPM, 1979).

Para a elaboração do mapa de substrato rochoso utilizado nas análises efetuadas nesta pesquisa (Figura 08) utilizou-se como base, prioritariamente, os mapas geológicos, na escala 1:50.000, de Maniakas (1986), IG (1993) e UNESP (1986) e, secundariamente, os mapas, na escala 1:100.000, do DNPM/CPRM (1984a, 1984b, 1984c e 1984d), complementados por observações de campo. As unidades de substrato rochoso que foram definidas e que estão representadas no mapa da Figura 08, compreendem os seguintes tipos litológicos: 


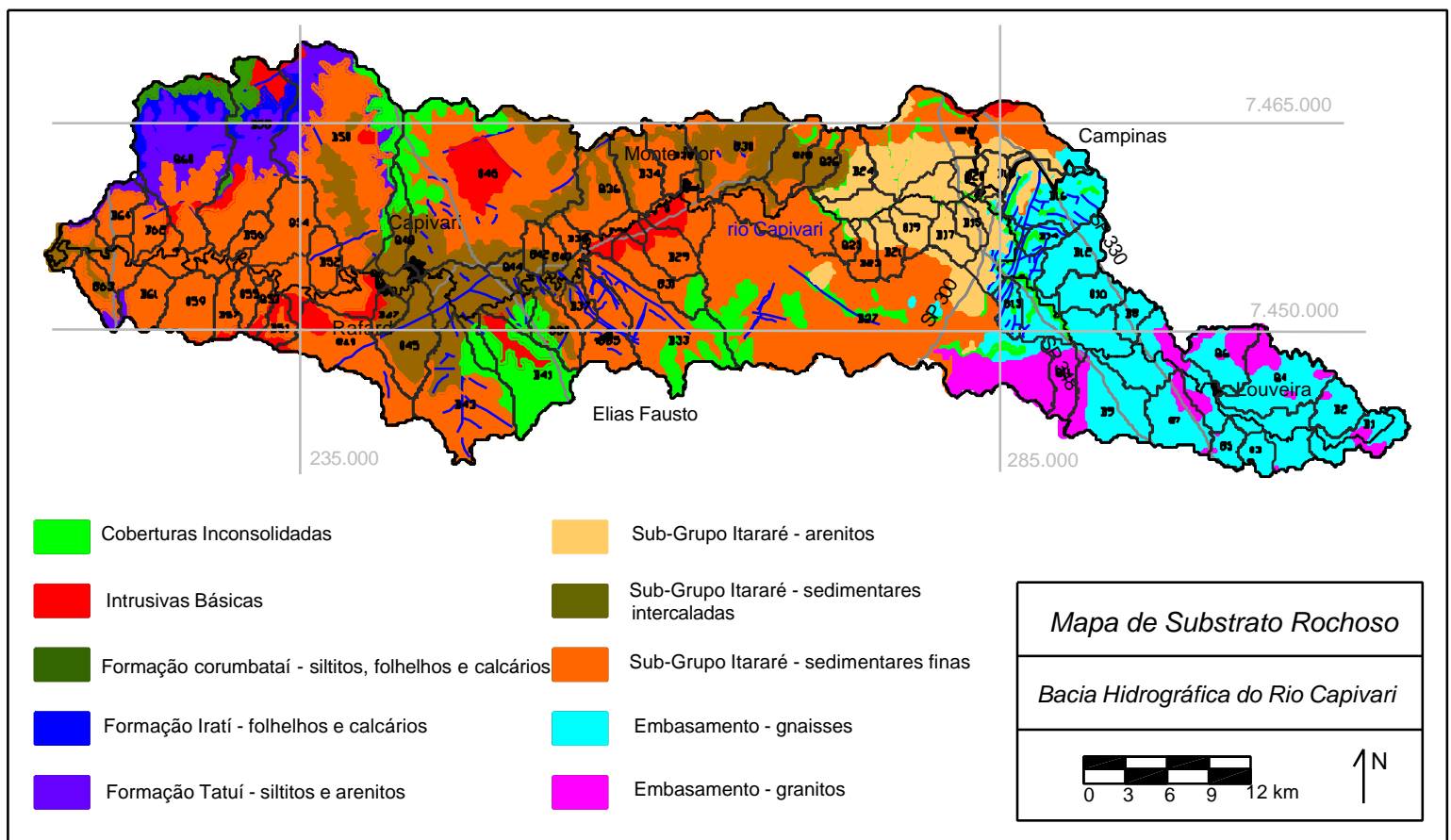

Figura 08: Mapa de substrato rochoso da bacia do Capivari (adaptado de Maniakas, 1986; IG, 1993; UNESP, 1986 e DNPM/CPRM, 1984a, 1984b, 1984c e 1984d). 
a) Embasamento - Granitos

A unidade aflora em alguns locais no setor leste da bacia, próximos à região de cabeceira. É composta por rochas graníticas equi a inequigranulares, com ocorrências ocasionais de granitóides máficos e intermediários. Localmente os granitos apresentam-se milonitizados.

b) Embasamento - Gnaisses

Representado pelo Embasamento Cristalino dominante na zona de cabeceira da bacia e composto, principalmente, por rochas do Complexo Itapira, conforme descrito por IG (1993) e UNESP (1986). As variações litológicas predominantes são biotita-gnaisse, gnaisse xistoso e granito-gnaisse. Próximo à cidade de Campinas é comum a presença de milonitos, devido à ocorrência de uma zona de cisalhamento.

c) Subgrupo Itararé - Sedimentares Finas

Os limites desta unidade correspondem aos definidos por Maniakas (1986) e DNPM/CPRM (1984a, 1984b, 1984c e 1984d) como sendo do Subgrupo Itararé Médio. Predominam rochas de granulometrias finas, representadas, principalmente, por siltitos, folhelhos e diamectitos.

d) Subgrupo Itararé - Sedimentares Intercaladas

É a unidade de maior ocorrência na bacia. Nas porções central e oeste correspondem, aproximadamente, aos limites definidos por Maniakas (1986) como sendo do Subgrupo Itararé Superior (Membro Tietê). Ocorrem rochas areníticas intercaladas com lamitos, siltitos, diamectitos e argilitos. No município de Campinas IG (1993) descreve a ocorrência de diamectitos e de ritmitos, constituídos por intercalações de arenitos finos, siltitos e argilitos.

e) Subgrupo Itararé - Arenitos

Esta unidade ocorre exclusivamente no setor sul do município de Campinas, nas adjacências do rio Capivari e foi diferenciada das outras que complementam o Subgrupo Itararé na bacia por constituir-se unicamente por arenitos. As variações faciológicas descritas por IG (1993) incluem arenitos com conglomerados, arenitos médios a grossos e arenitos finos a médios.

f) Formação Tatuí - Siltitos e Arenitos 
Aflora, predominantemente, na porção noroeste da bacia e em uma pequena área no setor sudoeste. É composta por siltitos, arenitos e siltitos arenosos. Localmente afloram níveis de sílex.

g) Formação Itatí - Folhelhos e Calcários

A unidade aflora apenas na porção noroeste da bacia e é composta por rochas calcárias, que são exploradas economicamente. Ocasionalmente podem ocorrer folhelhos e argilitos.

h) Formação Corumbataí - Siltitos, Folhelhos e Calcários

Aflora no extremo noroeste da bacia. As litologias predominantes nesta formação, descritas por Maniakas (1986) e Pejon (1992) são siltitos, folhelhos e calcários.

i) Intrusivas Básicas

Constituídas por diabásios da Formação Serra Geral que ocorrem na forma de sills e afloram em diversos pontos da bacia, concentrando-se, principalmente, no setor oeste e central. Em alguns locais os diabásios são explorados economicante como brita para a construção civil.

\section{j) Sedimentos Cenozóicos}

Os sedimentos Cenozoicos ocorrem, preferencialmente, nas adjacências de alguns canais de drenagens, inclusive no rio Capivari, e se distribuem por toda a bacia. Conforme descrição do IG (1993), tratam-se de sedimentos arenosos intercalados por camadas decimétricas de argilitos e lamitos. Maniakas (1986) destaca que é comum a ocorrência de brecha sedimentar na base.

\subsection{4 - Solos}

A descrição pedológica da área foi obtida com base nos mapas, na escala 1:500.000, derivados do trabalho efetuado por Kertzman et al (1991) na região que envolve a porção média da bacia do rio Tietê. Os autores estudaram a erodibilidade dos solos e os agrupou em associações pedológicas. Na bacia do rio Capivari afloram as associações I, II, IV e V (Figura 09). 


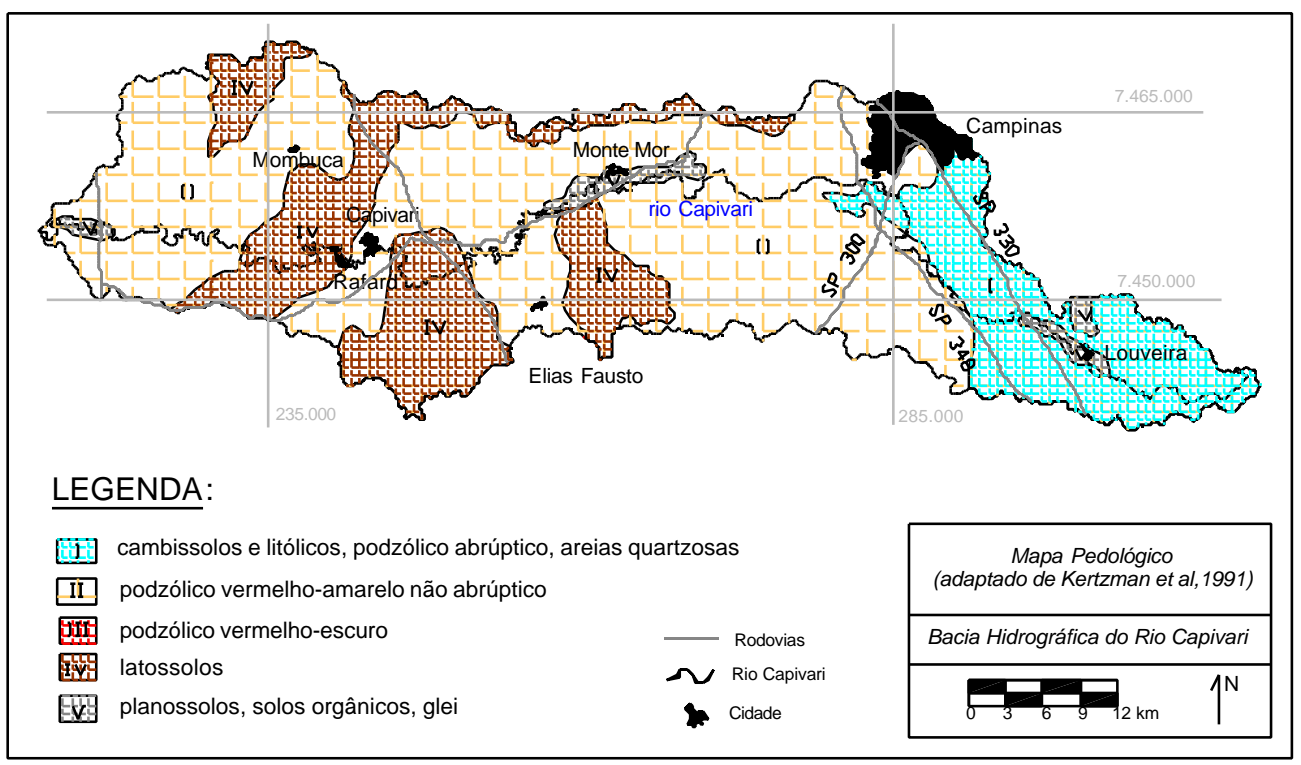

Figura 09 Mapa pedológico da bacia do rio Capivari - escala original 1:500.000 (adaptado de Kertzman et al, 1991).

A associação I compõe-se, preferencialmente, de solos litólicos e cambissolos e ocorre na zona de cabeceira da bacia, onde as declividades são mais acentuadas. Camadas de solos maduros, derivadas de rochas granitognáissicas do Embasamento Cristalino, são inexistentes ou pouco espessas.

A associação II é a mais representativa na bacia, cobre grande parte da porção central e oeste e é composta por solos podzólicos vermelho-amarelo de textura areno-argilosa a arenosa, derivados, principalmente, de rochas de textura média do Subgrupo Itararé. Segundo Kertzman et al (1991), são solos de alta erodibilidade.

A associação IV é composta por latossolos de textura argilosa, latossolo roxo e terra roxa estruturada. A ocorrência destes solos está associada ao substrato rochoso composto por intrusivas básicas e, ocasionalmente, rochas sedimentares finas. $A$ associação $V$ tem ocorrência restrita às planícies aluvionares adjacentes ao rio Capivari. São solos aluvionares muitas vezes ricos em matéria orgânica.

Kertzman et al (1991) estudaram a susceptibilidade à erosão destes terrenos considerando, além da erodibilidade das associações pedológicas, 
aspectos do relevo e do substrato rochoso. $\mathrm{Na}$ bacia do rio Capivari, duas áreas foram consideradas como sendo de muito alta susceptibilidade à erosão (Figura 10), e estão relacionadas à associação II, de solos podzólicos vermelho-amarelo de textura média. Áreas consideradas como de alta susceptibilidade à erosão estão também relacionadas aos solos podzólicos vermelho-amarelo ou às altas declividades ocorrentes na região de cabeceira da bacia.

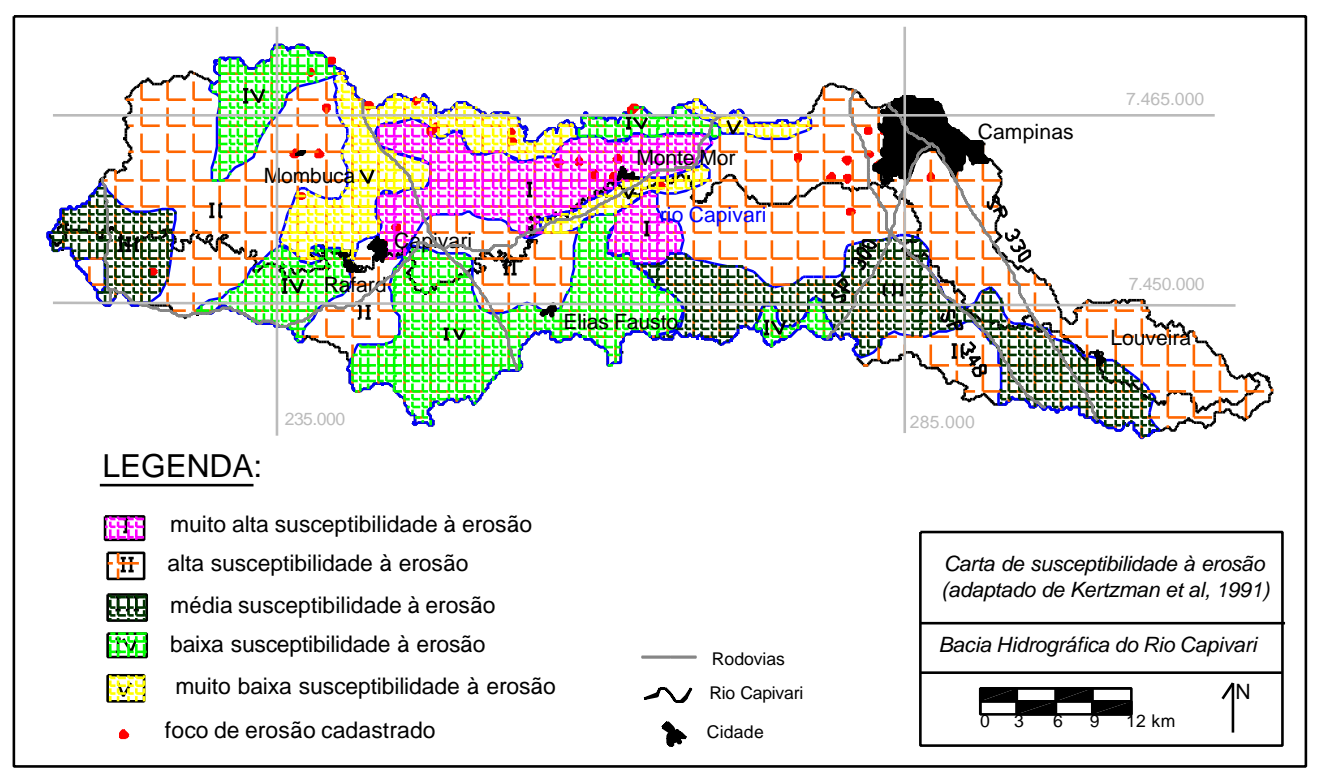

Figura 10: Carta de susceptibilidade à erosão da bacia do rio Capivari - escala original 1:500.000 (adaptado de Kertzman et al, 1991).

\subsection{5 - Aspectos da qualidade das águas}

De acordo com o Decreto 10.755 de 22/11/77, relativo à classificação dos corpos d'água do Estado de São Paulo e, posteriormente modificada pela Resolução 20 do CONAMA em 1986 (CETESB, 1995b), o rio Capivari deveria ser enquadrado como Classe 2 em toda a sua extensão, para o qual são estabelecidos os seguintes usos preponderantes:

- abastecimento doméstico após tratamento convencional;

- proteção das comunidades aquáticas;

- recreação de contato primário (natação, esqui-aguático e mergulho);

- irrigação de hortaliças e/ou plantas frutíferas;

- criação natural e/ou intensiva de espécies destinadas à alimentação humana. 
Apesar deste enquadramento, o rio Capivari não tem obedecido aos níveis de qualidade estabelecidos para esta classe. De acordo com os dados do monitoramento efetuado pela CETESB (1991b; 1992; 1993b; 1994; 1995b), tem prevalecido qualidade variando de ruim a péssima durante estes anos. Concentrações de coliformes fecais e totais, fósforo total, manganês, nitrogênio amoniacal, demanda bioquímica de oxigênio, e fenois têm ocorrido acima dos padrões estabelecidos para a Classe 2.

O gráfico da Figura 11 apresenta a contribuição dos diferentes setores para a poluição orgânica das águas da bacia do rio Capivari, de acordo com os dados do CBH-PCJ (1996). Das 25 ton $\mathrm{DBO}_{5} /$ dia remanescentes nos corpos d'água, mais de 95\% são de origem municipal e o grande responsável por estes números é a quase inexistência de tratamento dos efluentes domésticos. A Tabela 09 mostra a contribuição de cada município na poluição orgânica das águas da bacia.

Carga poluidora orgânica - 1995

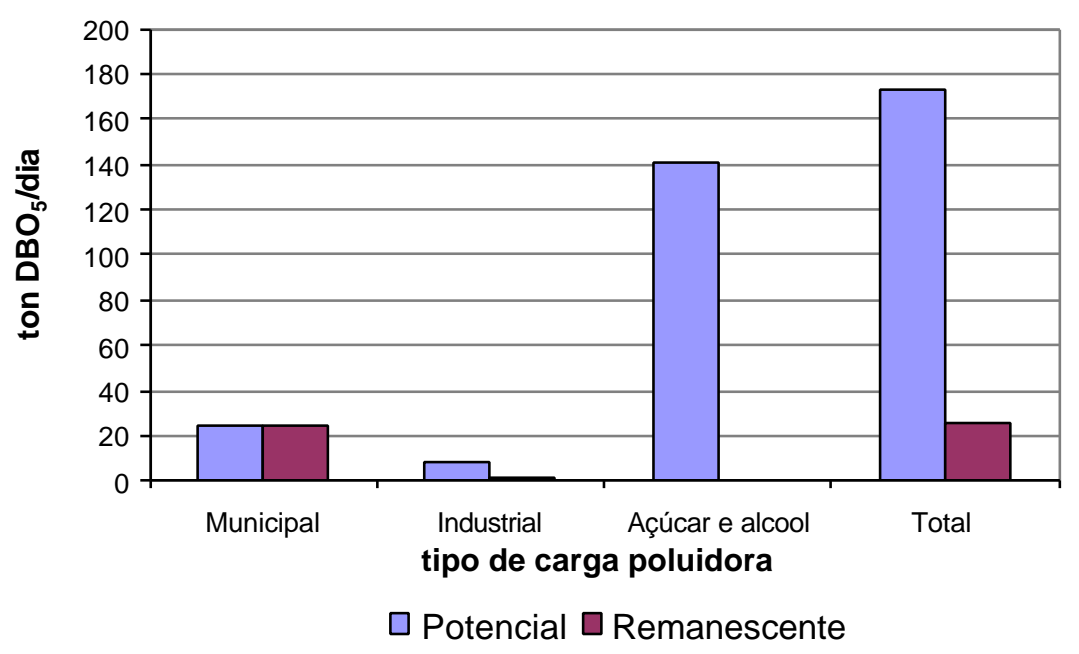

Figura 11: Carga poluidora orgânica na bacia do rio Capivari em 1995 (adaptado de CBH-PCJ, 1996). 
Tabela 09: Carga poluidora orgânica dos municípios que compõem a bacia do rio Capivari (adaptado de CBH-PCJ, 1996).

\begin{tabular}{cccc}
\hline \multirow{2}{*}{ Município } & \multicolumn{2}{c}{ Carga $\left(\mathbf{k g ~ D B \mathbf { D O } _ { 5 } / \mathbf { d i a } )}\right.$} & \multirow{2}{*}{ Corpo Receptor } \\
\cline { 2 - 4 } & Potencial & Remanescente & \\
\hline Campinas & 18.629 & 18.629 & Córrego Piçarrão \\
\hline Capivari & 1.903 & 1.903 & Rio Capivari \\
\hline Elias Fausto & 655 & 655 & Córrego Carneiro \\
\hline Louveira & 919 & 919 & Rio Capivari \\
\hline Mombuca & 145 & 32 & Córrego Mombuca \\
\hline Monte Mor & 1.438 & 1.438 & Rio Capivari \\
& & & Córrego Água Choca \\
\hline Rafard & 477 & 477 & Rio Capivari \\
\hline
\end{tabular}

Quanto às cargas industriais, observa-se no gráfico da Figura 11 a grande produção de carga orgânica gerada pelas usinas do setor de açúcar e álcool, entretanto, este contingente não é lançado diretamente nos corpos d'água e sim usado nas lavouras no processo de ferti-irrigação. A Tabela 10 mostra as cargas orgânicas e inorgânicas potenciais e remanescentes de algumas das principais indústrias instaladas na bacia do rio Capivari, conforme dados da CETESB (1996).

Tabela 10: Cargas orgânicas e inorgânicas geradas nas indústrias instaladas na bacia do rio Capivari (CETESB, 1996).

\begin{tabular}{|c|c|c|c|c|c|c|}
\hline Industria & Cidade & Atividade & $\begin{array}{l}\text { Orgânica } \\
\text { potencial } \\
\text { tDBO/ano }\end{array}$ & $\begin{array}{l}\text { Orgânica } \\
\text { remanes- } \\
\text { cente } \\
\text { (t/ano) }\end{array}$ & $\begin{array}{l}\text { Inorgânica } \\
\text { Potencial } \\
\text { (t/ano) }\end{array}$ & $\begin{array}{l}\text { Inorgânica } \\
\text { Remanes- } \\
\text { cente } \\
\text { (t/ano) }\end{array}$ \\
\hline Usina Açucareira Sta Cruz S.A & Capivari & $\begin{array}{l}\text { Açúcar e } \\
\text { álcool }\end{array}$ & $15.219,5$ & - & - & - \\
\hline $\begin{array}{l}\text { União São Paulo S.A Agricultura } \\
\text { Indústria e Comércio }\end{array}$ & Rafard & $\begin{array}{l}\text { Açúcar e } \\
\text { álcool }\end{array}$ & $14.953,8$ & - & - & - \\
\hline $\begin{array}{l}\text { Copersucar - Divisão de Refino e } \\
\text { Álcool }\end{array}$ & Rafard & Alcool & $5.600,1$ & - & - & - \\
\hline Indústria açucareira São Francisco S.A & $\begin{array}{l}\text { Elias } \\
\text { Fausto }\end{array}$ & Açucar & $1.703,1$ & - & - & - \\
\hline Sandoz S.A & Monte Mor & Química & 667,1 & - & - & - \\
\hline Frigorífico Antártico LTDA & Vinhedo & $\begin{array}{l}\text { Abate de } \\
\text { gado }\end{array}$ & 576,6 & - & - & - \\
\hline Albri Tintas e Resinas LTDA & Monte Mor & $\begin{array}{l}\text { Tintas e } \\
\text { resinas }\end{array}$ & 523,9 & - & - & - \\
\hline Nitton Papel S.A & Campinas & $\begin{array}{l}\text { Papel e } \\
\text { caixas de } \\
\text { papelão }\end{array}$ & 520,7 & - & - & - \\
\hline Curtume Firmino Costa S.A & Campinas & Curtume & 502,7 & 318,1 & 10,1 & $\overline{10,1}$ \\
\hline
\end{tabular}


Tabela 10 (continuação): Cargas orgânicas e inorgânicas geradas nas indústrias instaladas na bacia do rio Capivari (CETESB, 1996).

\begin{tabular}{|c|c|c|c|c|c|c|}
\hline Industria & Cidade & Atividade & $\begin{array}{l}\text { Orgânica } \\
\text { potencial } \\
\text { tDBO/ano }\end{array}$ & $\begin{array}{l}\text { Orgânica } \\
\text { remanes- } \\
\text { cente } \\
\text { (t/ano) }\end{array}$ & $\begin{array}{l}\text { Inorgânica } \\
\text { Potencial } \\
\text { (t/ano) }\end{array}$ & $\begin{array}{l}\text { Inorgânica } \\
\text { Remanes- } \\
\text { cente } \\
\text { (t/ano) }\end{array}$ \\
\hline Curtume Cantúsio S.A & Campinas & Curtume & 502,6 & 318,0 & 10,1 & 10,1 \\
\hline Ashland Resinas Sintéticas LTDA & Campinas & $\begin{array}{l}\text { Tintas e } \\
\text { resinas }\end{array}$ & 173,5 & 173,1 & - & - \\
\hline $\begin{array}{l}\text { Indústria e Comércio Dako do Brasil } \\
\text { S.A }\end{array}$ & Campinas & Fogões & - & - & 550,0 & 220,0 \\
\hline Mercedes Benz do Brasil S.A & Campinas & Veículos & - & - & 174,2 & 69,7 \\
\hline Metalúrgica Rigitec LTDA & Capivari & $\begin{array}{l}\text { Peças para } \\
\text { veículo } \\
\text { automotor }\end{array}$ & - & - & 6,7 & 2,7 \\
\hline $\begin{array}{l}\text { Stumpp \& Schuele do Brasil Ind. E } \\
\text { Com. LTDA }\end{array}$ & Campinas & $\begin{array}{l}\text { Material de } \\
\text { transportes } \\
\text { e molas }\end{array}$ & - & - & 4,0 & 0,6 \\
\hline Robert Bosch LTDA & Campinas & $\begin{array}{l}\text { Material } \\
\text { elétrico e } \\
\text { comunica- } \\
\text { ções }\end{array}$ & 58,5 & - & 1,8 & 0,7 \\
\hline Singer do Brasil Ind. E Com. LTDA & Campinas & $\begin{array}{l}\text { Maquinas } \\
\text { de costura }\end{array}$ & - & - & 1,4 & 0,6 \\
\hline $\begin{array}{l}\text { Miracema Nuodex Indústria Química } \\
\text { LTDA }\end{array}$ & Campinas & $\begin{array}{l}\text { Acidos } \\
\text { Graxos } \\
\text { Destilados } \\
\text { e Glicerina }\end{array}$ & 212,8 & - & - & - \\
\hline Indústrias Gessy Lever LTDA & Indaiatuba & Perfumaria & 100,0 & - & - & - \\
\hline Avícola Paulista LTDA & Louveira & $\begin{array}{l}\text { Criação de } \\
\text { aves e } \\
\text { fabricação } \\
\text { de farinha }\end{array}$ & 95,6 & - & - & - \\
\hline Ceval Alimentos S.A & Jundiaí & $\begin{array}{l}\text { Abate de } \\
\text { aves }\end{array}$ & 111,0 & - & - & - \\
\hline
\end{tabular}

Os resíduos sólidos também constituem uma fonte potencial de poluição das águas superficiais e subterrâneas. Segundo dados da CETESB (1993a), são gerados 778,4 t/dia de resíduos na bacia do Capivari, distribuídos entre resíduos classe I, II e III (Tabela 11). Os resíduos domésticos urbanos somavam em 1992 um total de $239 \mathrm{t} / \mathrm{dia}$, dos quais mais de $85 \%$ eram dispostos adequadamente no aterro sanitário de Campinas (Tabela 12). Para os resíduos industriais, não há aterros na região e as indústrias, por sua vez, também não têm sistemas de disposição para resíduos sólidos nos locais onde elas operam (CETESB, 1991a).

$\mathrm{Na}$ área rural os problemas ambientais potenciais estão condicionados ao uso inadequado de agrotóxicos, utilizados indiscriminadamente nos hotifruti e ao manejo incorreto do solo em épocas de plantio, por manter o solo desnudo por 
longos períodos, principalmente nas extensas áreas de cana de açúcar. Esta questão é agravada em terrenos de solos podzólicos arenosos, como na região central da bacia, entre Elias Fausto, Capivari e Monte Mor, onde já existem registros de diversas erosões (CBH-PCJ, 1997 e KERTZMAN et al, 1991).

Tabela 11: Quantidade de resíduos sólidos, por classes, gerada na bacia do rio Capivari (adaptado de CETESB, 1993).

\begin{tabular}{c|c|c}
\hline Classe do Resíduo & Tipo do Resíduo & Quantidade (t/dia) \\
\hline I & perigosos & 13.6 \\
\hline II & não inertes & 764.6 \\
\hline III & inertes & 0.2 \\
\hline Total & & 778.4 \\
\hline
\end{tabular}

Tabela 12: Quantidade de resíduos sólidos domésticos, por municípios, gerada na bacia do rio Capivari (adaptado de CETESB, 1993).

\begin{tabular}{l|c|l}
\hline \multicolumn{1}{c|}{ Município } & Quantidade de Lixo t/dia & \multicolumn{1}{c}{ Tipo de Destino } \\
\hline Campinas & 196.8 & aterro sanitário \\
\hline Capivari & 17.0 & lixão \\
\hline Elias Fausto & 3.5 & lixão \\
\hline Louveira & 8.0 & aterro sanitário \\
\hline Mombuca & 0.7 & lixão \\
\hline Monte Mor & 10.0 & lixão \\
\hline Rafard & 3.0 & lixão \\
\hline \multicolumn{1}{c}{ Total } & 239.0 & \\
\hline
\end{tabular}

A intensa atividade minerária de areia e argila que ocorre ao longo do rio Capivari tem provocado o assoreamento, o aumento da turbidez e o de sólidos suspensos nas águas, o desbarrancamento das margens e a desconfiguração da 
paisagem em algumas áreas. Das minerações que estão instaladas na bacia do rio Capivari a maior parte atua ilegalmente; segundo dados da CETESB (1997), apenas 32 têm licença para funcionar. 


\section{4 - LEVANTAMENTO DE CARACTERÍSTICAS DE USO E OCUPAÇÃO DO TERRENO E ATIVIDADES ANTRÓPICAS}

\section{1 - Considerações iniciais}

Neste capítulo é apresentada uma sistemática de trabalho, com uso de técnicas de geoprocessamento, para a obtenção do mapa de uso e ocupação e levantamento das atividades modificadoras do meio físico. Os documentos obtidos foram utilizados, posteriormente, na análise temporal das alterações ocorridas em componentes da paisagem.

O uso de técnicas de geoprocessamento está se tornando indispensável no desenvolvimento de estudos geoambientais de bacias hidrográficas, especialmente aquelas ligadas a procedimentos que priorizam o processamento de imagens e que facilitam a interação entre o operador e o sistema. Com o advento de recursos de sensoriamento remoto mais aperfeiçoados, o levantamento das informações tende a ser mais preciso e rápido e com o avanço nos sistemas de comunicação via rede, deverá haver maior facilidade para disponibilização, troca de informações e atualização de dados.

$\mathrm{Na}$ definição dos sistemas para utilização nesta pesquisa optou-se por programas que fossem ágeis na inserção de dados e que apresentassem duas características básicas: interação e versatilidade. A grande quantidade de informações a ser digitalizada e processada, aliada à necessidade de manipulação recíproca entre dados vetoriais e rasterizados, foram fatores determinantes na escolha. O programa ENVI $3.0^{\circledR}$ foi utilizado para o processamento de imagens de satélite Landsat - TM e obtenção do mapa de uso e ocupação e o programa Autocad Map $3.0^{\circledR}$ para o processamento dos dados referentes às atividades modificadoras do meio físico e dos dados obtidos a partir de fotointerpretações. 
Nos próximos sub-capítulos são apresentadas as técnicas adotadas para a obtenção dos documentos e os passos para a efetivação de cada procedimento nos programas utilizados. Para uma melhor exposição dos passos descritos algumas convenções foram adotadas:

a) a descrição da sequência de comandos é apresentada com um tipo de fonte menor (Arial 9) que a empregada no texto do trabalho (Arial 11);

b) os comandos descritos são comandos de menu e estão dispostos em sequência, separados por uma flecha $(\rightarrow)$. A necessidade de clicar "OK" após alguns comandos fica subentendida;

c) as expressões entre aspas significam o título de uma nova janela que se abre após executar um comando;

d) as expressões entre parênteses indicam algum procedimento de seleção que deve ser executado com o uso do mouse.

\section{2 - Obtenção do mapa de uso e ocupação}

\subsection{1 - Processamento de imagens de satélite}

O termo sensoriamento remoto tem sofrido modificações com o passar dos anos, à medida que novas tecnologias vêm surgindo. Novo (1989), procura retratar este processo e o define como sendo o resultado da "utilização conjunta de sensores, equipamentos para processamento de dados, equipamentos de transmissão de dados, aeronaves ou espaçonaves, com o objetivo de estudar o ambiente terrestre através do registro e da análise das interações entre a radiação eletromagnética e as substâncias componentes do planeta Terra em suas mais diversas manifestações".

Schowengerdt (1983), ao estudar a evolução do sensoriamento remoto, comenta que até o final da década de 60 imperou o uso de fotografias aéreas nos estudos relacionados à superfície terrestre e destaca como grande marco no seu desenvolvimento o advento da série de satélites Landsat, em 1972. Foi nesta época que surgiram as primeiras técnicas para o processamento digital de imagens. 
Por processamento digital de imagens entende-se a manipulação numérica de imagens, que inclui pré-processamento, realce e extração de informações temáticas, também denominada classificação (Jensen, 1986).

O pré-processamento tem por objetivo a transformação de dados digitais brutos em imagens corrigidas, dentre as quais constam correções radiométrica, geométrica e atmosférica. Após corrigidas as imagens devem passar pelo processo de georeferenciamento.

Após a etapa de pré-processamento, utiliza-se técnicas de realce para o melhoramento visual das imagens, o que permite extração de informações mais acuradas. Moik (1980) considera o contraste, a textura, a forma e a cor como os parâmetros mais significantes na sensibilidade de um observador humano e divide os métodos de realce em quatro categorias: realce de contraste (modificações na escala de cinza), realce de bordas, realce de cor e realce espectral.

A última etapa envolve a extração de informações temáticas, ou seja, a classificação da imagem. Neste contexto, classificação deve ser entendida como sendo o processo de se atribuir a cada unidade da imagem (pixel) um valor que o caracteriza como pertencente a uma determinada classe, dentro de um universo de classes. Para imagens pancromáticas, o critério de classificação mais difundido é por fatiamento, onde se subdivide o intervalo total de níveis de cinza em um determinado número de faixas, posteriormente denominadas de classes temáticas.

Para as imagens multiespectrais, Moik (1980), Jensen (1986) e Mather (1987) agrupam os critérios de classificação em dois grupos: classificação não supervisionada e classificação supervisionada.

A classificação não supervisionada é normalmente utilizada quando não se tem informações sobre a área estudada, ou então, como um processo de classificação preliminar para auxiliar na busca de informações para uma classificação supervisionada. Para esta técnica de classificação utilizam-se de formulações matemáticas assistidas por computador onde são identificados padrões típicos de reflectância. 
Uma ferramenta comumente utilizada na classificação não supervisionada é o diagrama de dispersão n-dimensional. Este diagrama permite a visualização dos pixels de amostras da imagem no espaço $n$-dimensional, onde $n$ é o número de bandas espectrais utilizadas na classificação; assim, agrupamentos de pixels que não se dispersam à medida que os eixos são rotacionados, são considerados pertencentes a uma mesma classe. Segundo Novo (1989), quanto maior a heterogeneidade das amostras utilizadas na classificação, maior a certeza de que todas as classes possíveis estarão representadas.

A classificação supervisionada é a mais comumente utilizada para extração de informações temáticas referentes ao uso e ocupação do solo. Para efetuar este tipo de classificação necessita-se de um conhecimento prévio sobre a área a ser classificada. As informações conhecidas serão convertidas em amostras de treinamento, que representam o comportamento médio de cada uma das classes a serem mapeadas.

No processamento, os pixels da imagem não pertencentes às amostras de treinamento são classificados como pertencentes à uma das classes préestabelecidas. Os métodos estatísticos mais comumente utilizados são: Método do Paralelepípedo, Método da Distância Mínima da Média e Método da Máxima Verossimilhança.

No método do paralelepípedo considera-se uma área (paralelepípedo) no espaço n-dimensional, ao redor da amostra de treinamento e, por lógica simples booleana "e/ou" (Jensen, 1986), enquadra-se ou não os pixels desconhecidos na classe. Caso o valor do pixel não se enquadre entre os valores máximos e mínimos de nenhuma das classes, deve, então, ser inserido em uma categoria denominada não classificada. Este fato faz com que o resultado final da classificação apresente um certo número de pixels não classificados.

O método da distância mínima da média é um método simples e comumente utilizado quando o número de amostras de treinamento é pequeno. Consiste no cálculo dos valores médios dos pixels pertencentes a cada classe em cada banda espectral. Os pixels desconhecidos são classificados naquela classe cuja média seja mais próxima a ele. 
O método da máxima verossimilhança tem como suporte matemático a estatística paramétrica multivariada, onde as classes são definidas, com base nas amostras de treinamento, pelos vetores das médias e matrizes de covariância. No processo de classificação, cada pixel passa a ser definido por um vetor $\mathrm{X}$, que expressa a sua probabilidade de pertencer a cada uma das classes. O pixel é então classificado naquela classe com a maior probabilidade. Este método é recomendado quando se conhece bem a região a ser classificada, permitindo a definição de amostras de treinamento bem representativas (Crósta, 1993).

\subsection{2 - O programa ENVI 3.0}

O ENVI $3.0^{\circledR}$ é um sistema para o processamento avançado de dados de sensoriamento remoto que pode estar ligado diretamente a um processador da linguagem IDL (Interactive Data Language), o que permite a inserção de rotinas apropriadas ao tipo de tratamento que se deseja efetuar.

Dentre os aplicativos que constam no programa estão ferramentas para correções geométricas de imagens de satélite; interface para georeferenciamento em diversos sistemas de projeções cartográficas, com base em mapas préexistentes ou imagens previamente georreferenciadas; ferramentas de realce padronizadas e interativas; filtros de convolução, morfológicos e de textura; sistemas para classificações e refinamento das imagens classificadas; modelo digital de terrenos e visualização 3D e outras ferramentas típicas dos Sistemas de Informações Geográficas (SIGs), tais como: manipulação de dados vetoriais, superposição de mapas e layout para mapas temáticos.

Para fins da obtenção de mapas de uso e ocupação, com base em imagem de satélite, o ENVI $3.0^{\circledR}$ apresenta duas ferramentas que merecem destaque por constituírem o diferencial com relação a outros programas de processamento de imagens: o recurso de visualização e manipulação do diagrama de dispersão $n$ dimensional e o aplicativo classedit. 
O diagrama de dispersão n-dimensional permite a visualização e seleção dos pixels da imagem no espaço n-dimensional, onde $n$ é o número de bandas usadas na classificação. Esta ferramenta é útil tanto na efetivação de classificações não supervisionadas, permitindo a definição de clusters que serão utilizados como amostras de treinamento no processamento da classificação, quanto no refinamento de amostras de treinamento determinadas em um processo de classificação supervisionada.

O classedit é um aplicativo desenvolvido no Brasil e por enquanto só integra os pacotes que são distribuídos no país. Trata-se de uma ferramenta de grande utilidade no refinamento das imagens classificadas, uma vez que permite a livre manipulação e reclassificação dos pixels que foram mal classificados. A interface deste aplicativo mostra no display a imagem original e as classes da imagem classificada podem ser inseridas, uma a uma, em sobreposição a esta imagem, permitindo, assim, uma melhor visualização dos contornos e das áreas mal classificadas.

\subsection{3 - Processamento das imagens da bacia do rio Capivari}

Para a obtenção do mapa de uso e ocupação da bacia do rio Capivari foram utilizados dois quadrantes de cenas de imagens de satélite Landsat - TM (96 x 96 $\mathrm{km}$ ), datadas de maio e agosto de 1996 (Tabela 13). No processamento utilizou-se as bandas espectrais $1(0,45-0,52 \mu \mathrm{m}), 2(0,52-0,60 \mu \mathrm{m}), 3(0,63-0,69 \mu \mathrm{m}), 4$ $(0,76-0,90 \mu \mathrm{m}), 5(1,55-1,75 \mu \mathrm{m})$ e $7(2,08-2,35 \mu \mathrm{m})$. A banda 6 não foi utilizada por apresentar resolução espacial $(120 \times 120 \mathrm{~m})$ menor que as outras bandas $(30 \times 30 \mathrm{~m})$.

Tabela 13: Imagens de satélite Landsat - TM utilizadas para a obtenção do mapa de uso e ocupação da bacia do rio Capivari.

\begin{tabular}{l|l|l|l|l|l}
\hline $\begin{array}{c}\text { Código } \\
\text { do produto }\end{array}$ & Base & Ponto & Quadrante & $\begin{array}{c}\text { Data da } \\
\text { passagem }\end{array}$ & $\begin{array}{c}\text { Bandas } \\
\text { adquiridas }\end{array}$ \\
\hline 6966 & 219 & 76 & W & $13 / 05 / 96$ & $1,2,3,4,5$ e 7 \\
\hline 6966 & 220 & 76 & E+ & $24 / 08 / 96$ & $1,2,3,4,5$ e 7 \\
\hline
\end{tabular}


As duas imagens foram tratadas separadamente e só no final do processo foram unidas para estabelecer o mapa de uso e ocupação da bacia do rio Capivari. A sequência dos procedimentos adotada no processamento das imagens de satélite é mostrada no esquema da Figura 12 e descrita nos próximos subcapítulos.

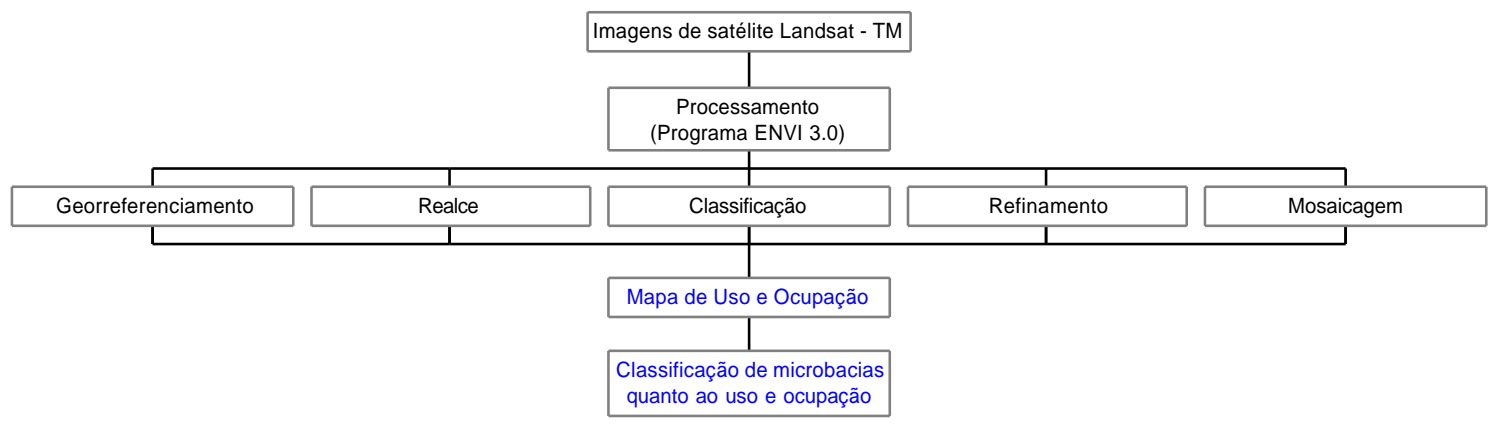

Figura 12: Esquema adotado no processamento das imagens de satélite.

\subsubsection{1 - Georeferenciamento}

As imagens foram georreferenciadas em coordenadas UTM (Universal, Transverse Mercator), com base em mapas topográficos do IBGE, na escala 1:50.000, das quadrículas de Jundiaí (IBGE, 1971), Campinas (IBGE, 1974), Indaiatuba (IBGE, 1973a), Americana (IBGE, 1970a), Porto Feliz (IBGE, 1970d), Capivari (IBGE, 1970b), Salto (IBGE, 1973b) e Ibitiruna (IBGE, 1970c).

A cena que cobre o setor leste da bacia foi a primeira a ser georreferenciada e para tal utilizou-se o procedimento de georeferenciamento de mapa para imagem. A sequência de comandos utilizada na execução deste procedimento foi a seguinte:

REGISTER $\rightarrow$ SELECT GROUND CONTROL POINTS $\rightarrow$ IMAGE TO MAP $\rightarrow$ "IMAGE TO MAP REGISTRATION" $\rightarrow$ (selecionar o sistema de coordenadas e o tamanho do pixel) $\rightarrow$ "GROUND CONTROL POINTS SELECTION" $\rightarrow$ (selecionar pontos na imagem $\rightarrow$ CTRL + MOUSE ESQUERDO $\rightarrow$ inserir coordenadas do ponto $\rightarrow$ ADD POINT) $\rightarrow$ OPTIONS $\rightarrow$ WARP FILE $\rightarrow$ (selecionar imagem a 
ser georreferenciada) $\rightarrow$ "REGISTRATION PARAMETERS" $\rightarrow$ (selecionar parâmetros de georeferenciamento) $\rightarrow$ OK

Foram obtidos 24 pontos de controle dos mapas do IBGE, escolhidos, preferencialmente, em cruzamentos de estradas ou ruas. Referências como interseções entre canais de drenagens ou curvas de rios devem ser evitadas, por serem representadas com menos acuidade nos mapas topográficos e por estarem sujeitas à variações sazonais.

A averiguação da precisão no momento da inserção dos pontos de controle pode ser obtida instantaneamente, à medida que novos pontos vão sendo inseridos, com base nos valores do RMS error (erro médio quadrático) (Figura 13). O RMS error é uma medida do desvio dos valores calculados em relação aos valores originais. O valor obtido para a cena do setor leste foi de 0,2223.

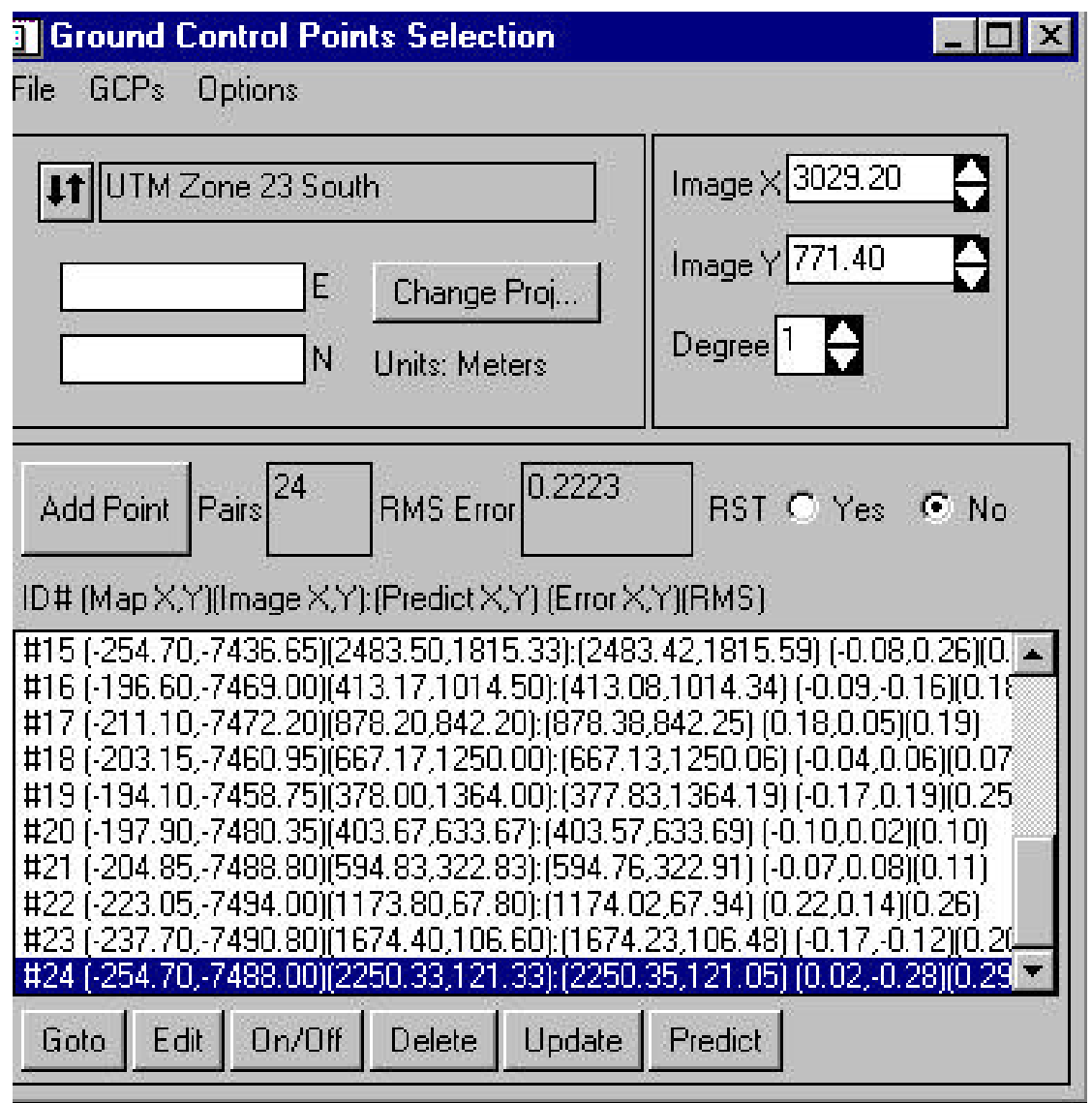

Figura 13: Layout da janela de inserção de pontos do ENVI $3.0^{\circledR}$ e o RMS Error. 
A cena do setor oeste foi georreferenciada utilizando-se do procedimento imagem para imagem, aproveitando a extensa área de sobreposição entre as duas cenas. A sequência de comandos utilizada na execução deste procedimento foi a seguinte:

(abrir as duas imagens no display) $\rightarrow$ REGISTER $\rightarrow$ SELECT GROUND CONTROL POINTS $\rightarrow$ IMAGE TO IMAGE $\rightarrow$ "IMAGE TO IMAGE REGISTRATION" $\rightarrow$ (selecionar a imagem base e a imagem a ser georreferenciada) $\rightarrow$ "GROUND CONTROL POINTS SELECTION" $\rightarrow$ (selecionar pontos na imagem base $\rightarrow$ CTRL + MOUSE ESQUERDO $\rightarrow$ selecionar pontos na imagem a ser georreferenciada $\rightarrow$ CTRL + MOUSE ESQUERDO $\rightarrow$ ADD POINT) $\rightarrow$ OPTIONS $\rightarrow$ WARP FILE $\rightarrow$ (selecionar imagem a ser georreferenciada) $\rightarrow$ "REGISTRATION PARAMETERS" $\rightarrow$ (selecionar parâmetros de georeferenciamento) $\rightarrow$ OK

Esta opção foi escolhida pela maior versatilidade deste método, que permite a manipulação das duas imagens no display. Foram escolhidos 22 pontos de controle e o RMS error obtido foi de 0,2654.

O processo de construção de um mosaico com as duas cenas para obtenção de uma única imagem para a bacia poderia ter sido efetuado após o georeferenciamento, entretanto, este procedimento pode alterar os valores espectrais dos pixels e interferir no processo de classificação. Por isto, optou-se por efetuar realces e classificar as cenas separadamente e, só posteriormente, efetuar a construção do mosaico.

\subsubsection{2 - Aplicação de realce}

Independente do número de bandas da imagem original a ser utilizado no processo de classificação, é importante que sejam feitas escolhas entre as bandas disponíveis de forma a permitir combinações coloridas para visualização no display. Estas combinações de bandas podem ainda serem tratadas, por meio de aumento de contrastes, de forma a permitir uma melhor visualização das características desejadas.

Para fins da obtenção de mapas de uso e ocupação, o uso de combinações coloridas é especialmente importante no momento da definição das amostras de 
treinamento a serem utilizadas na classificação e, posteriormente, para o refinamento da imagem classificada no aplicativo classedit.

Para este trabalho utilizou-se, preferencialmente, a combinação das bandas 4-5-3, no sistema RGB. Eventualmente, outras combinações de bandas, ou mesmo a visualização de bandas isoladas também foram utilizadas. O programa ENVI $3.0^{\circledR}$ possui um recurso (link) que permite visualização, em uma janela aberta no display, de parte da imagem com uma determinada composição de bandas em uma outra janela com outra banda ou combinação de bandas (Figura 14). A sequência de comandos utilizada na execução deste procedimento foi a seguinte:

\section{FUNCTIONS $\rightarrow$ LINK $\rightarrow$ LINK DISPLAYS}

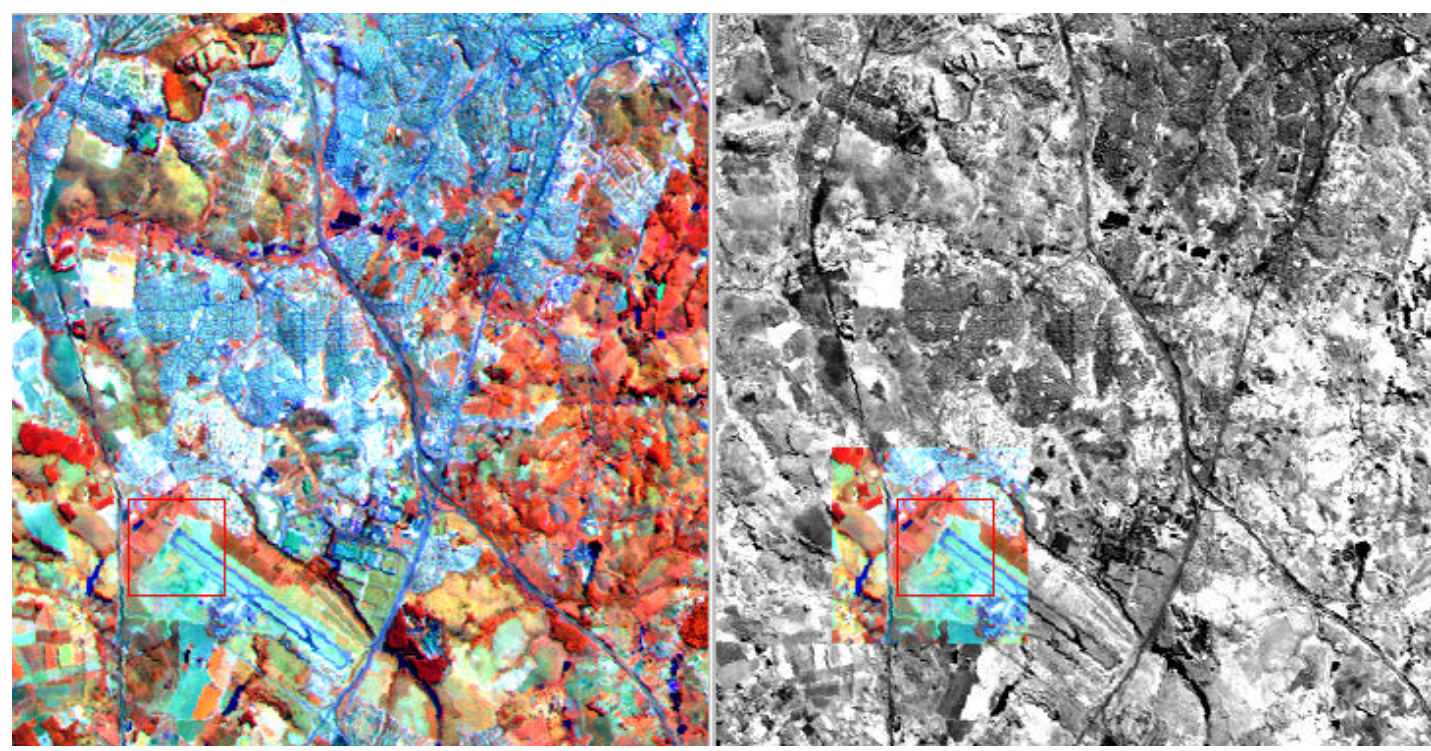

a) Composição de bandas 4-5-3

b) Banda 4 com link da composição 4-5-3

Figura 14: Utilização do recurso link do programa ENVI 3.0.

Para melhorar a resolução visual das imagens, utilizou-se aumentos de contrastes nas combinações de bandas. Inicialmente utilizou-se o contraste padrão do programa que constitui um aumento linear com corte de $2 \%$ dos valores extremos do histograma com os valores de níveis de cinza dos pixels da imagem.

À medida que se fez necessário, utilizou-se aumentos de contrastes interativos. Estes foram utilizados, preferencialmente, para proporcionar uma 
melhor definição das amostras de treinamento. A sequência de comandos utilizada na execução deste procedimento foi a seguinte:

FUNCTIONS $\rightarrow$ DISPLAY ENHANCEMENTS $\rightarrow$ INTERACTIVE STRETCHING $\rightarrow$ "HISTOGRAMAS DE ENTRADA E SAÍDA no display" $\rightarrow$ (por meio de manipulação dos histogramas escolhe-se o novo contraste)

O recurso de aumento de contraste interativo do ENVI $3.0^{\circledR}$ mostra automaticamente no display os histogramas da imagem original e da imagem realçada, e permite ao usuário acompanhar o resultado da operação diretamente em uma imagem de saída (Figura 15).

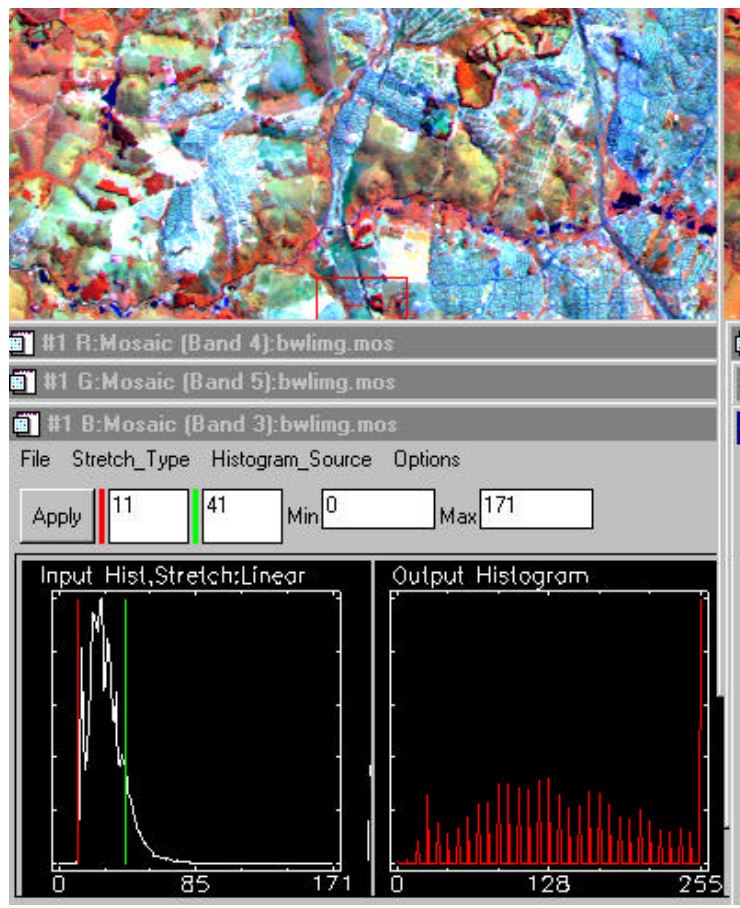

a) após o contraste interativo

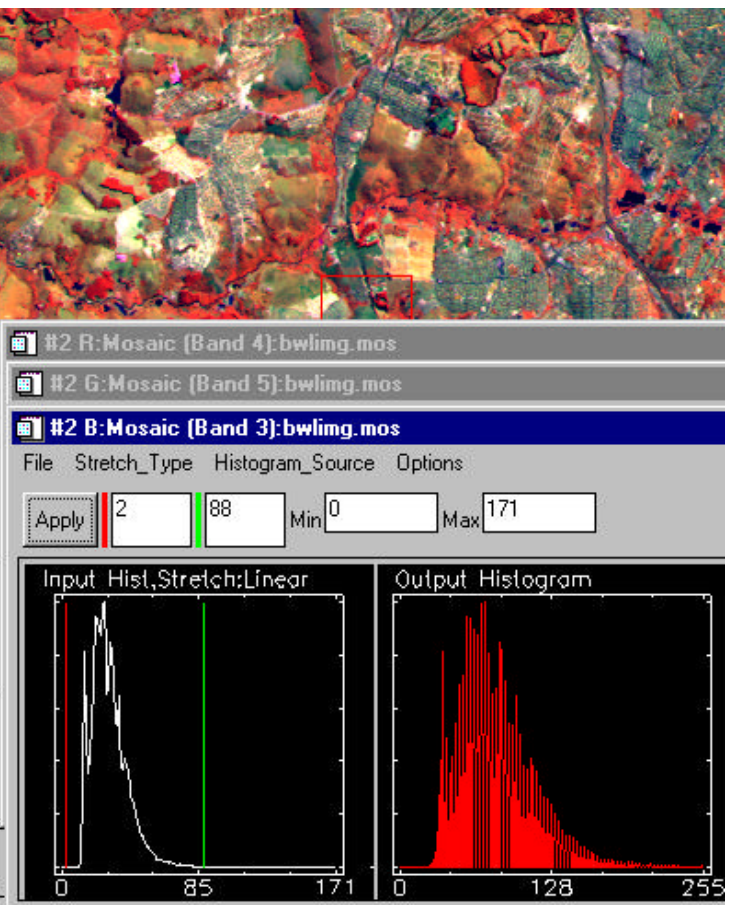

b) antes do contraste interativo

Figura 15: Utilização do recurso de contraste interativo do ENVI 3.0, através da manipulação dos histogramas de tons de cinza dos pixels em diferentes bandas espectrais.

Vale ressaltar que qualquer procedimento de aumento de contraste só implica em mudanças na imagem para efeito de visualização no display e não há, portanto, interferência nos resultados da classificação. 


\subsubsection{3 - Classificação}

A sequência dos trabalhos efetuados na classificação das imagens para fins da obtenção do mapa de Uso e Ocupação da bacia do rio Capivari pode ser enumerada em três etapas: pré-classificação, levantamento de campo para obtenção das amostras de treinamento e classificação supervisionada das imagens.

No processo de pré-classificação efetuou-se uma classificação não supervisionada das imagens com o único objetivo de observar a amplitude de classes possíveis e direcionar o levantamento de campo subsequente.

Para este procedimento determinou-se as amostras de treinamento com base em clusters obtidos a partir da visualização e manipulação de diagramas de dispersão n-dimensionais (Figura 16) correspondentes às regiões previamente escolhidas na imagem. Para este caso optou-se por regiões de interesse bem heterogêneas (Figura 16a). A sequência de comandos utilizada na execução deste procedimento foi a seguinte:

a) para a definição da amostra de treinamento:

FUNCTIONS $\rightarrow$ REGION OF INTEREST $\rightarrow$ DEFINE REGION OF INTEREST $\rightarrow$ "REGION OF INTEREST CONTROLS" $\rightarrow$ (seleciona-se a região de interesse na imagem)

b) para a visualização do diagrama e definição de amostras de classes:

SPECTRAL TOOLS $\rightarrow$ n DIMENSIONAL VISUALIZER $\rightarrow$ VISUALIZE WITH NEW DATA $\rightarrow$ "n D VISUALIZER" e "n D CONTROLS" $\rightarrow$ (seleciona-se as bandas para visualização no diagrama) $\rightarrow$ (manipulação do diagrama com START/STOP) $\rightarrow$ (definição de amostras de classes no " $\mathrm{D}$ VISUALIZER") $\rightarrow$ (exportar amostras de classes para "REGION OR INTEREST CONTROLS" ) $\rightarrow$ "n D CONTROLS" $\rightarrow$ OPTIONS $\rightarrow$ EXPORT ALL

Após escolhidas amostras de treinamento que descrevessem satisfatoriamente agrupamentos de níveis de cinza nas imagens (amostras de classes), procedeu-se à classificação, sem a preocupação de reconhecer o significado de cada uma das classes. 

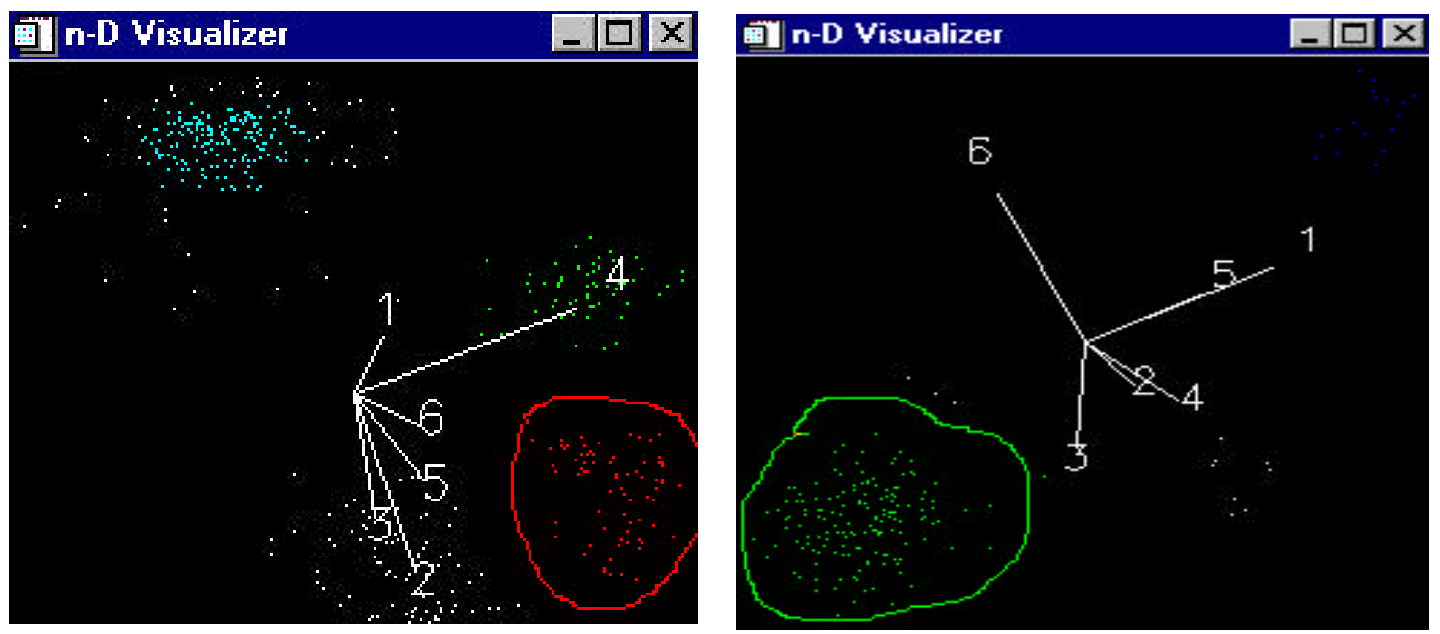

a) definição de amostras de treinamento (clusters) para efetivação de classificação não supervisionada

b) refinamento de uma amostra de treinamento para efetivação de classificação supervisionada

Figura 16: Diagramas de dispersão n-dimensionais do programa ENVI 3.0.

A segunda etapa do processo foi efetuada com o intuito de obter amostras de treinamento de cada classe para a classificação supervisionada. Para o levantamento de campo utilizou-se de uma cópia das imagens georreferenciadas nas bandas 5-4-3, uma cópia das imagens previamente classificadas, fotografias aéreas na escala 1:60.000, mapas topográficos na escala 1:50.000 e um GPS com precisão de $30 \mathrm{~m}$. Foram investigadas e demarcadas, na cópia da imagem georreferenciada, 85 amostras de treinamento correspondentes aos diferentes tipos de uso e ocupação ocorrentes na bacia.

Estas amostras de treinamento foram posteriormente transpostas para a imagem digital no programa ENVI $3.0^{\circledR}$ e refinadas. O refinamento das amostras foi efetuado com o objetivo de descartar possíveis pixels não correspondentes ao tipo de uso e ocupação da amostra em questão. Este processo foi feito utilizando-se dos diagramas de dispersão n-dimensional, que permitem isolar os pixels que mais se dispersam do grupo principal, como mostrado no exemplo da Figura 16b. 0 procedimento para definição das amostras de treinamento e utilização do diagrama de dispersão é o mesmo descrito no processo de pré-classificação.

Para a classificação supervisionada o método estatístico que foi efetivamente utilizado foi o da máxima verossiminhança, aproveitando-se do grande número e tamanho das amostras de treinamento e do bom conhecimento prévio da 
área. O grau de significância utilizado foi de $\propto=0,05$. Os métodos do paralelepípedo e da distância mínima da média foram também testados, porém os resultados foram menos satisfatórios. A sequência de comandos utilizados para a classificação foi a seguinte:

CLASSIFICATION $\rightarrow$ SUPERVIZED $\rightarrow$ MAXIMUM LIKELIHOOD $\rightarrow$ "CLASSIFICATION INPUT FILE" $\rightarrow$ (seleciona-se a imagem a ser classificada) $\rightarrow$ "MAXIMUM LIKELIHOOD PARAMETERS" $\rightarrow$ (seleciona-se as amostras de treinamento e os parâmetros de classificação) $\rightarrow$ OK

As classes de uso e ocupação que puderam ser distinguidas e amostras com sua aparência nas imagens, compostas a partir das bandas 4-5-3, são apresentadas na Tabela 14 e na Figura 17 (a-h).

Tabela 14: Tipos de uso e ocupação levantados na bacia do rio Capivari para serem utilizados como amostras de treinamento na classificação supervisionada.

\begin{tabular}{|c|c|}
\hline Tipo de uso e ocupação & Referência \\
\hline Centro urbano & área urbana central \\
\hline Ocupação mediamente adensada & $\begin{array}{l}\text { periferia das cidades e pequenos núcleos } \\
\text { urbanos }\end{array}$ \\
\hline Ocupação pouco adensada & $\begin{array}{l}\text { concentrações de chácaras e ocupações } \\
\text { dispersas }\end{array}$ \\
\hline Hortifruti e outras culturas & $\begin{array}{l}\text { plantações de uva, morango, caquí, goiaba, } \\
\text { tomate, pimentão, etc.; plantações de café, } \\
\text { milho, batata, etc. }\end{array}$ \\
\hline Cana de açúcar I & área pronta para o corte (fase madura) \\
\hline Cana de açúcar II & $\begin{array}{l}\text { área plantada recentemente (em fase de } \\
\text { amadurecimento) }\end{array}$ \\
\hline Cana de açúcar III & área em preparação para plantio \\
\hline Mata / reflorestamento & mata nativa e reflorestamentos \\
\hline Pastagem / capoeira & pastagem e capoeira \\
\hline Solo exposto & $\begin{array}{l}\text { área com solo descoberto por mineração, área } \\
\text { de empréstimo ou disposição de lixo }\end{array}$ \\
\hline Represas & represas \\
\hline
\end{tabular}



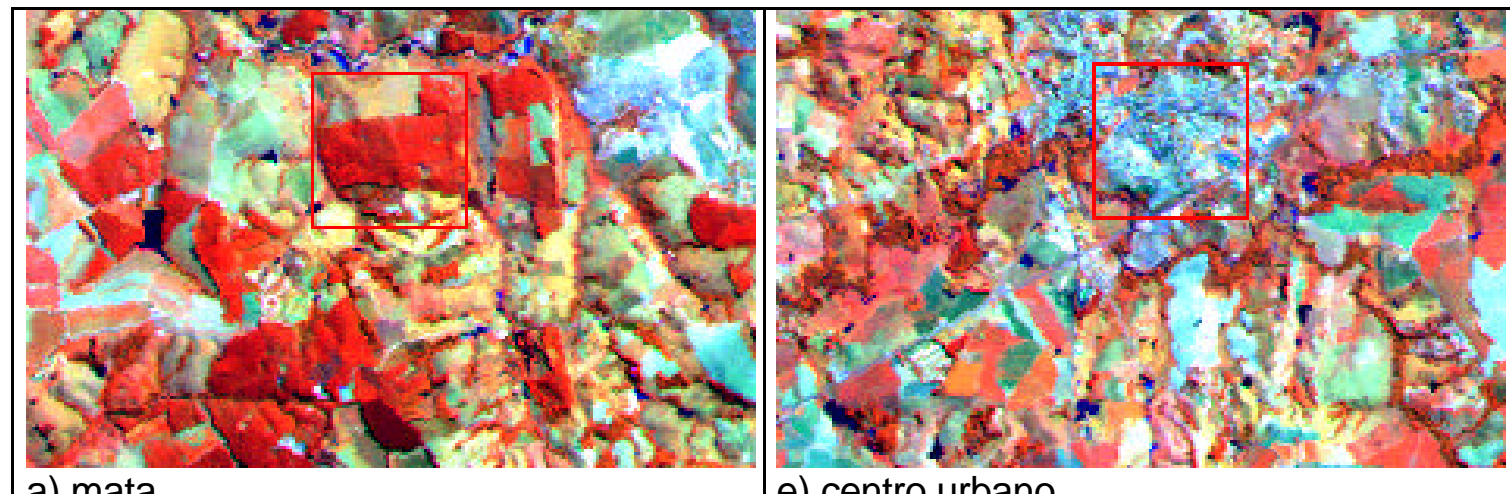

\section{a) mata}

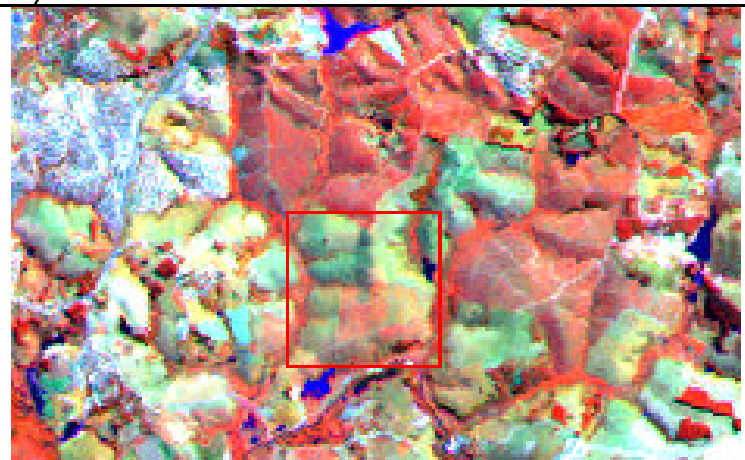

b) pastagem

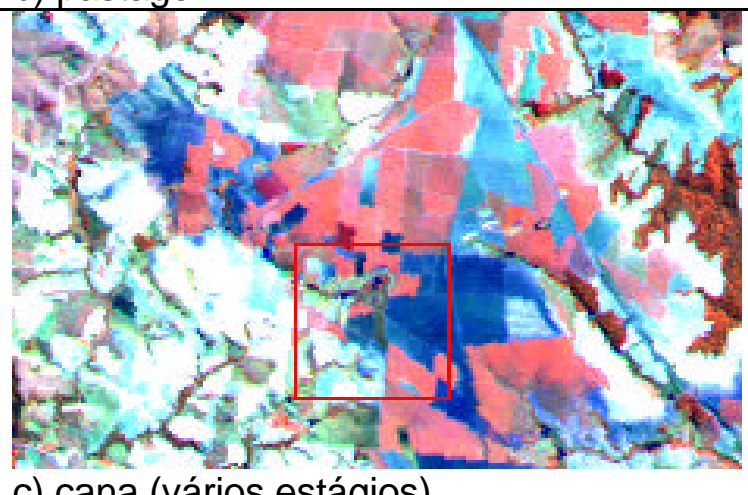

c) cana (vários estágios)

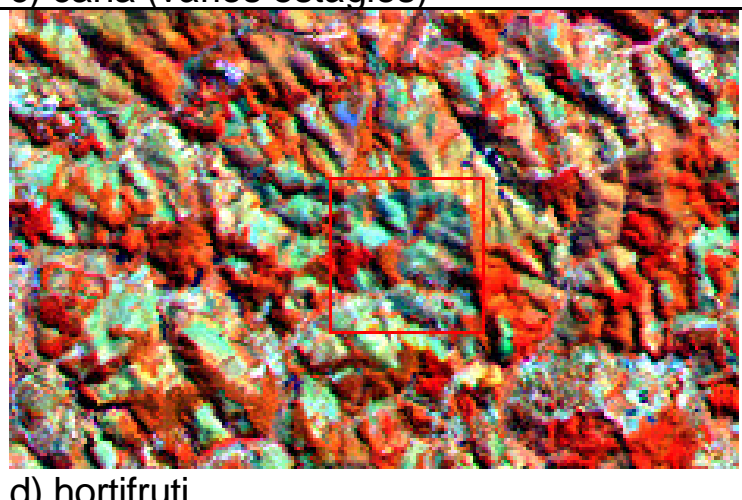

d) hortifruti

\section{e) centro urbano}

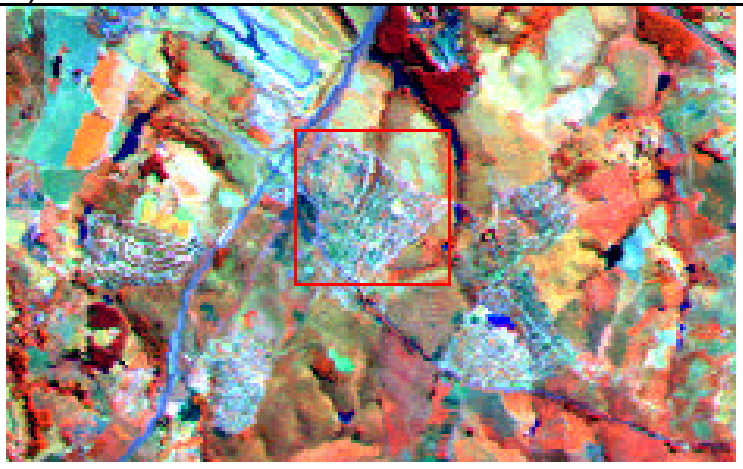

f) ocupação mediamente adensada

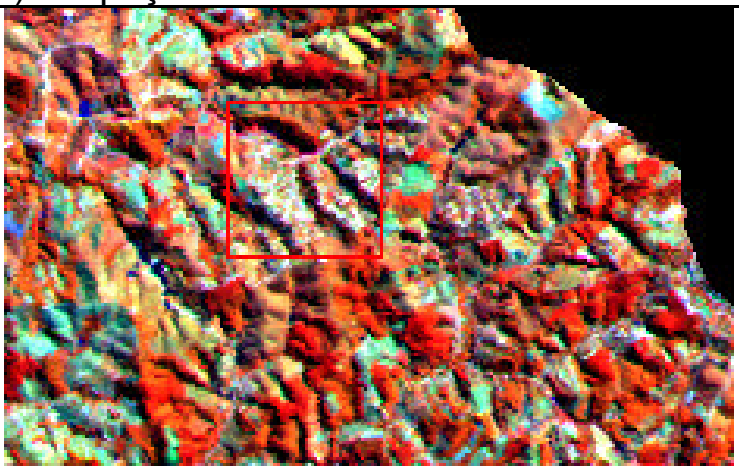

g) ocupação pouco adensada

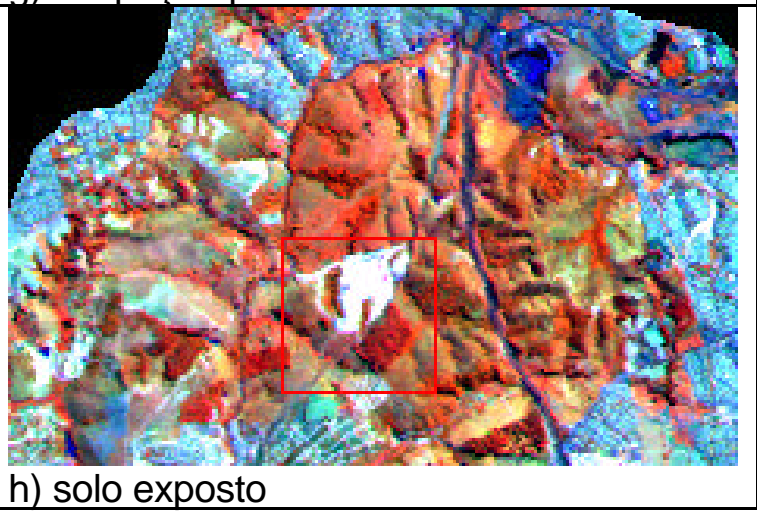

Figura 17: Aparência das amostras de treinamento das classes de uso e ocupação da bacia do rio Capivari na composição de bandas 4-5-3 (observar áreas demarcadas com o quadrado vermelho). 
Três classes de cana de açúcar foram consideradas inicialmente e depois do processo de classificação foram agrupadas. Isto se deu devido aos diferentes estágios da plantação, deste a cana pronta para o corte até áreas preparadas para o replantio. Foram necessárias amostras de treinamento que caracterizassem bem estes diferentes estágios, uma vez que refletiam em diferentes valores espectrais, como pode ser observado na Figura 17c.

A classe denominada Centro Urbano não foi utilizada no processo de classificação por apresentar pixels com níveis de cinza muito dispersos, abrangendo valores representativos de várias outras classes. Este fato é explicado pela ocorrência de áreas verdes, solo exposto e áreas desocupadas (com pastagem) no interior das áreas urbanas, que tipicamente são compostas por concreto e asfalto.

O uso de amostras de treinamento correspondentes a esta classe no processo de classificação provocaria uma superposição de valores e diminuiria a precisão na classificação das outras classes, por isto optou-se pela sua não inclusão. Outro fato que pesou nesta decisão foi a facilidade para a sua demarcação nas imagens sem a necessidade de usar algum tipo de processamento digital. Por representarem áreas contínuas, em pequeno número (apenas sete centros urbanos) e com geometria bem definida, elas puderam ser facilmente demarcadas com o uso do aplicativo classedit, após o processo de classificação.

\subsubsection{4 - Refinamento da classificação}

Após o processo de classificação é comum que a imagem apresente uma certa quantidade de ruídos (pixels mal classificados) no interior e nas adjacências das classes e, por isto, há a necessidade de um tratamento, pós-classificação, para que seja feita a absorção destes pixels mal classificados e para a posterior obtenção de uma imagem classificada limpa, com melhor aspecto visual.

Vários são os suportes disponíveis no programa ENVI 3.0 ${ }^{\circledR}$ que permitem o melhoramento do aspecto visual de imagens classificadas. Para o refinamento das imagens classificadas da bacia do rio Capivari foi utilizada a seguinte sequência de 
procedimentos: aplicação de um filtro de convolução mediano; função de aglutinação de classes (clump classes); função de separação de classes (sieve classes) e refinamento manual no classedit.

O filtro de convolução mediano foi utilizado como um primeiro passo no processo de homogeneização do resultado da classificação. Trata-se de um dos filtros de convolução passa-baixas, que permitem a remoção de ruídos nas imagens, provocando um efeito de suavização. No caso do filtro mediano, o processo é efetuado com uma máscara por cima da imagem, geralmente utilizando-se uma matriz $3 \times 3$, onde o pixel central da máscara é substituído pelo valor médio dos seus vizinhos. A sequência de comandos utilizada foi a seguinte:

a) para filtragem

FILTERS $\rightarrow$ CONVOLUTION $\rightarrow$ MEDIAN $\rightarrow$ "CONVOLUTION INPUT FILE" $\rightarrow$ (seleciona-se a imagem classificada) $\rightarrow$ "CONVOLUTION PARAMETERS" $\rightarrow$ (seleciona-se os parâmetros de filtragem) $\rightarrow$ OK

b) para restauração de cores na imagem filtrada

FILE $\rightarrow$ EDIT ENVI HEADER $\rightarrow$ "EDIT HEADER INPUT FILE" $\rightarrow$ (seleciona-se a imagem) $\rightarrow$ "HEADER INFO" $\rightarrow$ INPUT HEADER INFO FROM $\rightarrow$ OTHER FILE $\rightarrow$ "SELECT FILE FOR INPUT HEADER INFORMATION" $\rightarrow$ (seleciona-se a imagem classificada antes da filtragem) $\rightarrow$ OK $\rightarrow$ OK

O segundo passo foi a utilização das funções clumpe sieve que fazem parte do menu classification do ENVI $3.0^{\circledR}$ e servem, respectivamente, para aglutinar ou separar pixels isolados envoltos ou próximos de um grupo de pixels de uma determinada classe. Estas funções apresentam como opção indicar as classes que devem ser transformadas e o tamanho da máscara a ser utilizada. O inconveniente é que o processamento é efetuado em toda a imagem e não apenas em pontos isolados, fato este que pode provocar distorções em locais indesejados. As sequências de comandos para acessar cada uma destas funções são as seguintes:

a) função CLUMP

CLASSIFICATION $\rightarrow$ POST CLASSIFICATION $\rightarrow$ CLUMP CLASSES $\rightarrow$ "CLASSIFICATION INPUT FILE" $\rightarrow$ (seleciona-se a imagem classificada) $\rightarrow$ "CLUMP PARAMETERS" $\rightarrow$ (seleciona-se os parâmetros para o processamento) $\rightarrow \mathrm{OK}$ 
b) função SIEVE

CLASSIFICATION $\rightarrow$ POST CLASSIFICATION $\rightarrow$ SIEVE CLASSES $\rightarrow$ "CLASSIFICATION INPUT FILE" $\rightarrow$ (seleciona-se a imagem classificada) $\rightarrow$ "SIEVE PARAMETERS" $\rightarrow$ (seleciona-se os parâmetros para o processamento) $\rightarrow$ OK

Para o refinamento final utilizou-se o classedit (Figura 18) que permite a manipulação ponto a ponto na imagem, possibilitando ao usuário a correção de áreas que foram interpretadas incorretamente nos processos de classificação e refinamento. Na versão 3.0 do ENVI o classedit não vem acoplado ao programa e deve ser adquirido separadamente junto à empresa que comercializa o produto no Brasil. Nas versões mais recentes, o classedit vem como parte integrante do programa. A sequência de comandos para acesso ao classedit é a seguinte:

FUNCTIONS $\rightarrow$ EDITAR CLASSIFICAÇÃO $\rightarrow$ "SELECIONE IMAGEM INPUT BANDS" $\rightarrow$ (selecionar as bandas desejadas no sistema RGB) $\rightarrow$ "SELECIONE RESULTADO DE CLASSIFICAÇÃO" $\rightarrow$ (seleciona-se a imagem classificada) $\rightarrow$ OK

A opção da imagem original ao fundo e a inserção individual de classes em cima desta imagem, permitem um melhor delineamento das áreas ocupadas pelas classes, como pode ser observado no exemplo da Figura 18. O aplicativo permite ainda a manipulação de pixels isolados, possibilitando a transformação de seus valores de radiância, de forma que venham a pertencer a uma outra classe desejada.

Com estas funções foi possível delinear melhor os limites entre classes e retirar os ruídos que não puderam ser retirados com os procedimentos anteriores. Através deste aplicativo foi possível, também, inserir a classe Centro Urbano na imagem classificada, como mostrado no exemplo da Figura 19. 


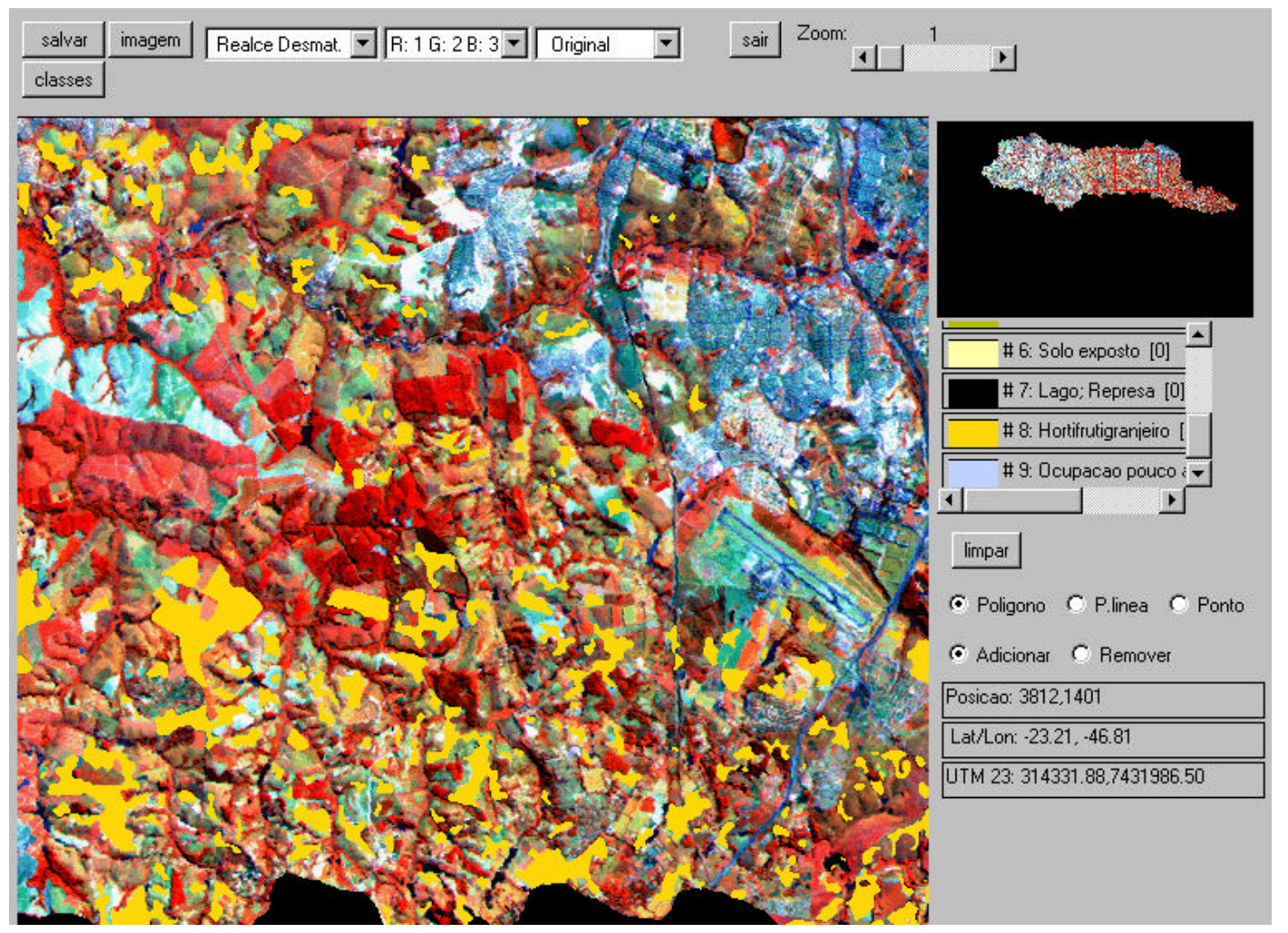

Figura 18: Layout do aplicativo Classedit mostrando a imagem de satétite ao fundo (bandas 4-5-3) e a classe Hortifruti sobreposta.

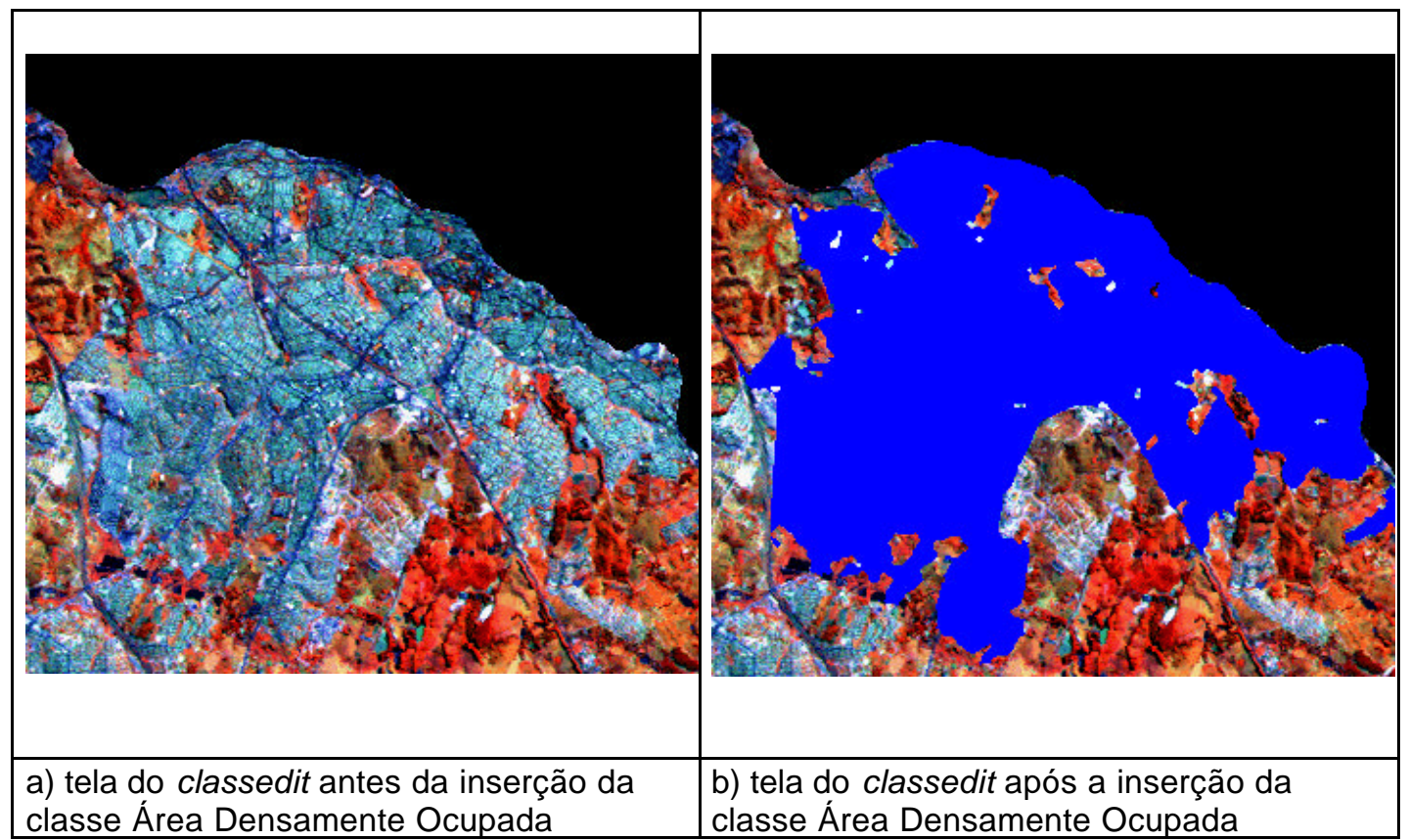

Figura 19: Delimitação da classe Centro Urbano com o uso do aplicativo classedit. 


\subsubsection{5 - Construção do mosaico e delimitação da bacias}

Conforme mencionado anteriormente, optou-se por efetuar a junção das duas imagens (construção do mosaico) após o processo de classificação e refinamento. Esta escolha justifica-se porque, no processo de construção do mosaico, os pixels tendem a sofrer uma transformação nos seus níveis de cinza originais, o que poderia comprometer a qualidade do resultado de classificação.

Antes da construção do mosaico das imagens puras (não classificadas), aplicou-se um mesmo realce interativo nas duas imagens, de forma a permitir uma homogeneização nos níveis de contrastes a que elas foram submetidas. Este procedimento foi possível copiando-se o histograma de níveis de cinza resultante do realce de uma das imagens para a outra imagem, por meio da função de contraste interativo já descrita anteriormente. Após este processo, as imagens puderam ser submetidas ao processo de construção do mosaico sem comprometer a qualidade visual do resultado. O uso de realces só é necessário para a construção de mosaicos em imagens puras; para as imagens classificadas não é necessário. A sequência de comandos utilizada para a construção dos mosaicos foi a seguinte:

REGISTER $\rightarrow$ MOSAIC IMAGES $\rightarrow$ GEOREFERENCED IMAGES $\rightarrow$ "GEOREFERENCED IMAGE MOSAICKING" $\rightarrow$ IMPORT $\rightarrow$ IMPORT FILE WITH FEATHERING OU IMPORT FILE WITHOUT FEATHERING $\rightarrow$ "MOSAIC INPUT FILE" $\rightarrow$ (seleciona-se uma das imagens) $\rightarrow$ IMPORT $\rightarrow$ IMPORT FILE WITH FEATHERING ou IMPORT FILE WITHOUT FEATHERING $\rightarrow$ (seleciona-se a outra imagem) $\rightarrow$ FILE $\rightarrow$ APPLY $\rightarrow$ "MOSAIC PARAMETERS" $\rightarrow$ (seleciona-se os parâmetros) $\rightarrow$ OK

A delimitação do perímetro da bacia foi efetuada, em um primeiro momento, considerando 112 pontos de controle retirados dos divisores de águas reconhecidos nos mapas topográficos do IBGE. Estes pontos, em seguida, foram transpostos para a imagem mosaicada e permitiram, assim, delinear o perímetro da bacia.

Em um segundo momento, após todo o processamento com as fotografias aéreas da área (descrito no Capítulo 5), foi substituído pelo perímetro traçado nos pares estereoscópios das fotografias aéreas, por ser este mais preciso. Para destacar na imagem apenas a área da bacia, aplicou-se uma máscara com base no 
polígono que define o perímetro da bacia. A sequência dos procedimentos utilizada para a delimitação do perímetro da bacia foi a seguinte:

a) para construir a máscara:

BASIC TOOLS $\rightarrow$ MASKING $\rightarrow$ BUILD MASK $\rightarrow$ "MASK DEFINITION" $\rightarrow$ (seleciona-se o display onde está a imagem pura) $\rightarrow$ OPTIONS $\rightarrow$ IMPORT ANNOTATION ou IMPORT ROIS (arquivo vetorial com a borda) $\rightarrow$ (seleciona-se o arquivo) $\rightarrow$ MASK DEFINITION $\rightarrow$ OK

b) para aplicar a máscara:

BASIC TOOLS $\rightarrow$ MASKING $\rightarrow$ APPLY MASK $\rightarrow$ "APPLY MASK INPUT FILE" $\rightarrow$ (seleciona-se a imagem pura) $\rightarrow$ SELECT MASK BAND $\rightarrow$ (seleciona-se a mascara) $\rightarrow$ "APPLY MASK PARAMETERS" $\rightarrow$ OK

A imagem pura em mosaico com os limites da bacia e a imagem classificada são apresentadas nas Figuras 20 e 21.

\section{3 - Levantamento das atividades modificadoras do meio físico}

Nesta etapa foram levantadas as potenciais atividades pontuais responsáveis pelas modificações na paisagem e na qualidade das águas na bacia do rio Capivari. Foram levantados e cadastrados as principais indústrias, as usinas de álcool e açúcar, os locais utilizados para disposição de lixo, as minerações ativas e abandonadas e as atividades agropecuárias de grande porte (granjas, pocilgas, etc.). Os dados foram inseridos em um banco de dados e conectados a uma base georreferenciada. A sequência dos procedimentos adotada nesta etapa é apresentada na Figura 22.

\subsection{1 - Levantamento dos dados existentes}

Em uma fase prévia ao levantamento de campo foram efetuadas visitas a órgãos estaduais e regionais em busca de inventários das atividades vigentes na bacia. Dentre os orgãos visitados estão prefeituras municipais, DAEE regional, CETESB, Consórcio Intermunicipal das bacias dos rios Piracibaba e Capivari , Instituto Geológico e Junta Comercial do Estado de São Paulo. 


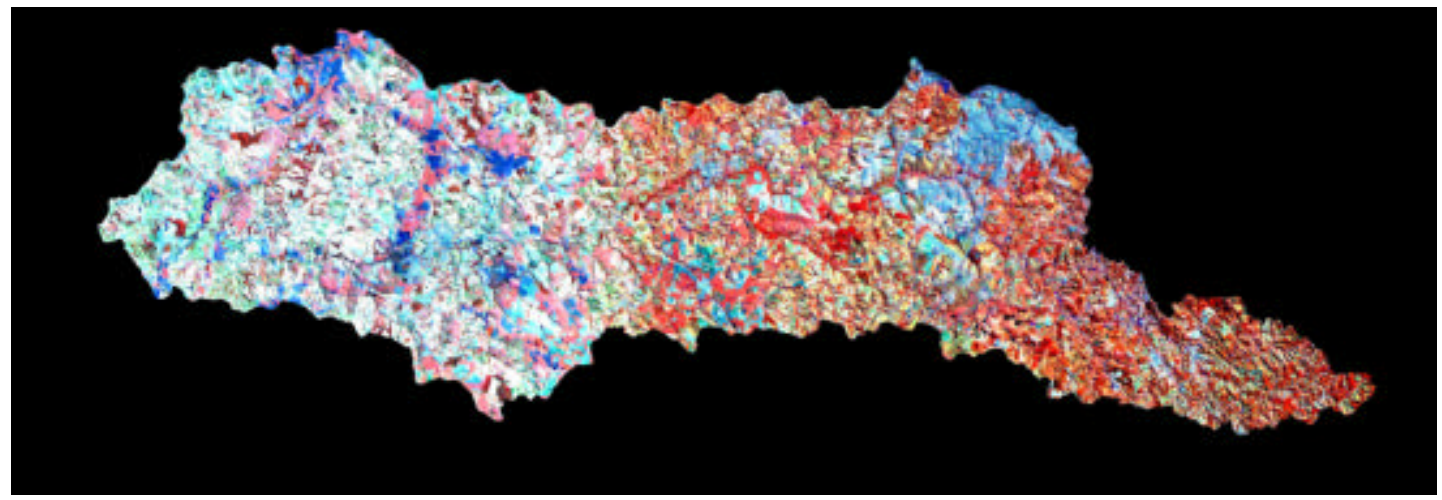

Figura 20: Imagem de satélite Landsat-TM (bandas 4-5-3) da bacia do rio Capivari. 


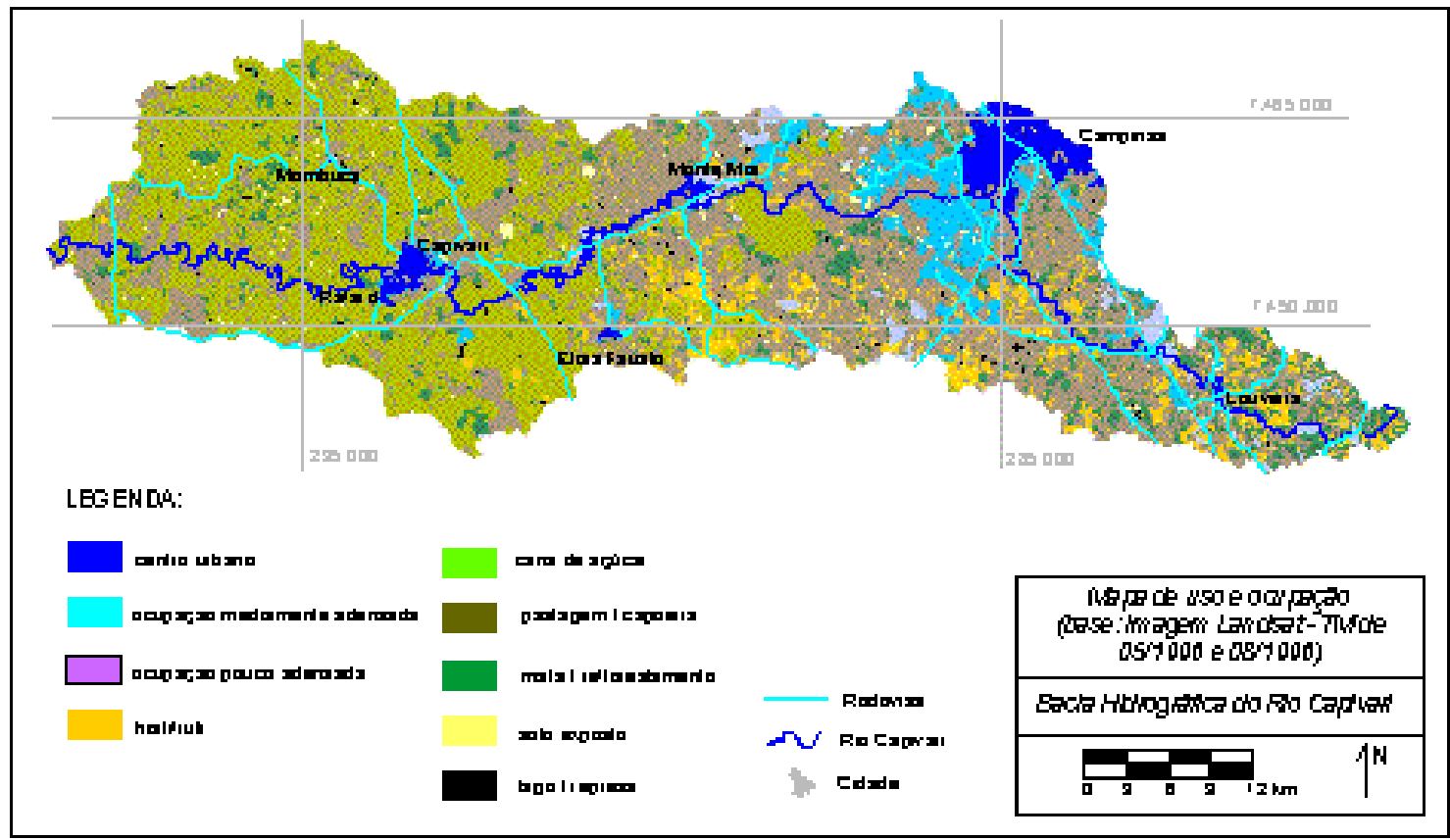

Figura 21: Mapa de uso e ocupação da bacia hidrográfica do rio Capivari. 


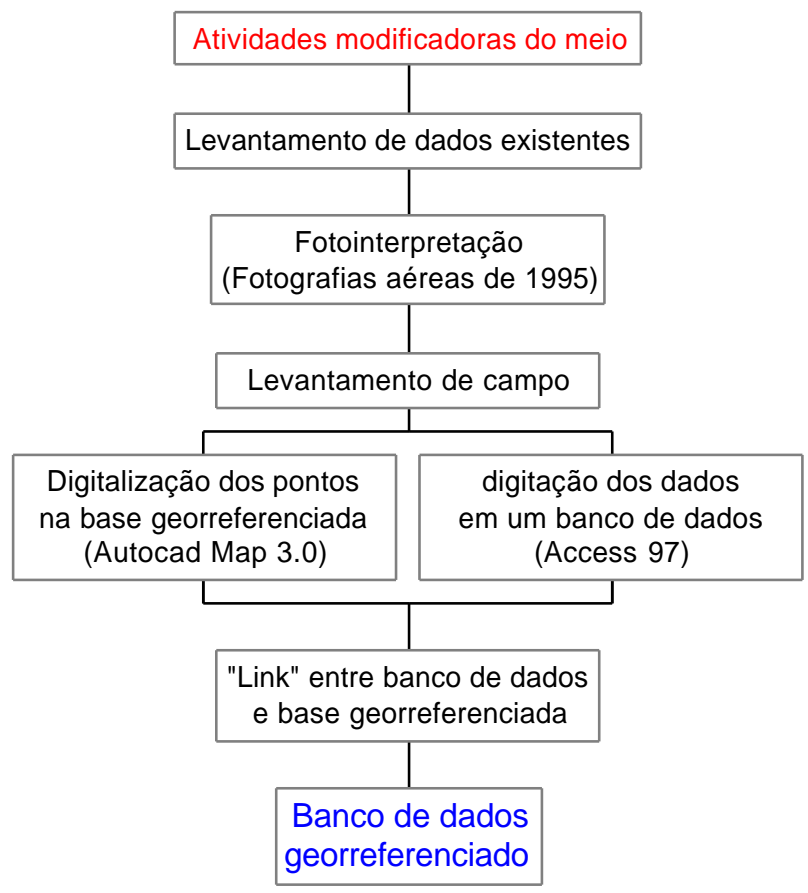

Figura 22: Sequência dos procedimentos adotados para a obtenção do banco de dados georreferenciado com as atividades modificadoras do meio..

Em alguns destes orgãos, foram encontrados dados sobre atividades antrópicas específicas, algumas delas restritas a determinados locais, como é o caso da Prefeitura Municipal de Campinas, por meio de seu plano diretor (PMC, 1995), e do Instituto Geológico (IG, 1993) que apresentam dados que se restringem aos limites do município de Campinas.

A Companhia de Tecnologia e Saneamento Ambiental do estado de São Paulo (CETESB, 1996) possui um cadastro onde constam as principais indústrias instaladas na bacia do rio Capivari, porém os registros não estão georeferenciados. Dentre os dados disponibilizados pela CETESB estão as atividades desenvolvidas pelas indústrias e as cargas orgânicas e inorgânicas, potenciais e remanescentes. Os registros foram conferidos e georeferenciados no levantamento de campo.

\subsection{2 - Levantamento de campo}

Para direcionar o levantamento de campo e torná-lo mais rápido, foi efetuada, previamente, uma fotointerpretação, utilizando-se das fotografias aéreas, 
na escala 1:25.000, de 1995, com o objetivo de demarcar as construções de grande porte e áreas com solo removido. Os locais definidos por construções de grande porte geralmente constituem indústrias, galpões industriais ou de atividades agropecuárias (granjas ou pocilgas) ou locais com grandes aglomerações humanas e as áreas com solo removido representam, preferencialmente, áreas mineradas ou de disposição de resíduos. As áreas demarcadas foram visitadas e descritas.

No campo, além da descrição geral dos pontos envolvendo as características do empreendimento, procurou-se observar as características do meio físico no local e as condições de uso e ocupação. Para o georeferenciamento dos pontos utilizou-se um GPS com precisão de $30 \mathrm{~m}$ e mapas topográficos do IBGE, na escala 1:50.000.

\subsection{3 - Elaboração do banco de dados georeferenciado}

Foram elaboradas duas tabelas de dados para a bacia do rio Capivari. A primeira, contendo as mensurações efetuadas para as redes de drenagem e as características morfométricas das microbacias (conforme descrito no Capítulo 5) e a segunda, referente às atividades modificadoras da paisagem, contendo os dados obtidos em pesquisa de arquivo e levantamento de campo.

Os arquivos de dados foram construídos no programa Access ${ }^{\circledR}$, e posteriormente foram acoplados à uma base georreferenciada contendo as imagens de satélite e o mosaico de fotografias aéreas da bacia, no programa Autocad Map $3 \cdot 0^{\circledR}$. A base apresenta, também, os limites e as redes de drenagem das microbacias que compõem a bacia.

As atividades modificadoras do meio físico estão demarcadas e numeradas, sendo cada tipo de empreendimento representado por uma dada cor e tamanho de caracteres, que é proporcional à área de abrangência do empreendimento. Os dados de cada atividade podem ser visualizados ao clicar do mouse em cima dos pontos e os dados das microbacias e sua rede de drenagem ao clicar nas bordas das microbacias. A Figura 23 apresenta um mapa com a demarcação dos pontos 
referentes às atividades modificadoras do meio físico. As planilhas com os dados dos pontos cadastrados então expostos no Apêndice 4.

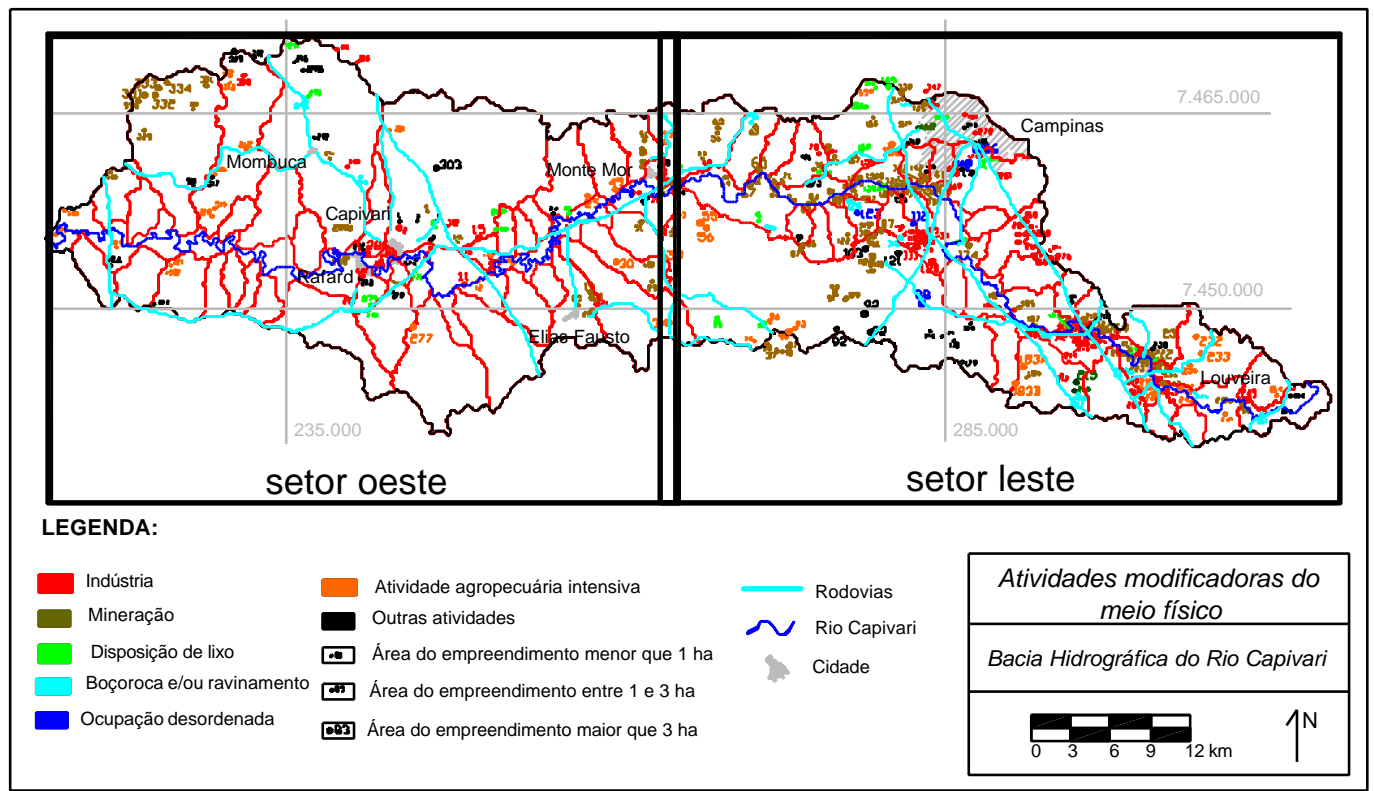

Figura 23: Mapa das atividades modificadoras do meio físico da bacia do Capivari. 


\section{4 - Análise temporal de intervenções antrópicas}

Para a efetivação da análise temporal foram utilizadas fotografias aéreas, na escala 1:25.000, datadas de 1972 e de 1995. As fotografias aéreas constituíram um instrumento de grande utilidade no levantamento das intervenções antrópicas ocorridas na bacia do rio Capivari, uma vez que algumas características da paisagem não foram passíveis de análise nas imagens de satélite, devido à baixa resolução espacial. O registro do terreno em duas datas distintas, com uma defasagem de 23 anos, tornou possível, também, a análise comparativa das modificações ocorridas na rede de drenagem da bacia (conforme descrito no Capítulo 5).

Para facilitar as avaliações, a bacia foi compartimentada em 64 microbacias de $4^{a}, 5^{a}$, e $6^{a}$ ordens de ramificação, mais a área adjacente ao leito do rio Capivari, de forma que cada um destes compartimentos pudesse ser analisado individualmente quanto às suas características de uso e ocupação e intervenções antrópicas ocorridas entre os anos de 1972 e 1995.

A fotointerpretação foi efetuada utilizando-se de pares estereoscópios das fotografias aéreas e um estereoscópio de espelho da marca Carl Zeizz ${ }^{\circledR}$. Os seguintes registros foram efetuados: limites e redes de drenagem das microbacias; áreas mineradas ou de disposição de resíduos; represas; rodovias asfaltadas e áreas urbanizadas.

Para a análise foi necessária a quantificação dos parâmetros obtidos com a fotointerpretação e para isto os dados foram digitalizados e processados. A seguência de operações utilizadas neste procedimento foi: escaneamento, construção de mosaicos, georeferenciamento e digitalização.

Este conjunto de operações foi efetuado com auxílio do Autocad Map 3.0 ${ }^{\circledR}$. Este programa permite a inserção de dados vetoriais e operações topológicas com vários arquivos ao mesmo tempo, possibilitando, assim, que os dados possam ser armazenados em arquivos separados (por grupos de microbacias), evitando sobrecarga do sistema. Os detalhes dos procedimentos adotados para a obtenção e quantificação dos dados vetoriais são explicados no Capítulo 5. 
Na análise comparativa das alterações devido a ocorrência de represas, áreas mineradas e de disposição de resíduos, procurou-se relacionar a área compreendida por estas formas de ocupação com a área total das microbacias, permitindo, assim, indicar as microbacias que mais sofreram com estas intervenções. Foi efetuada também uma análise para verificar o avanço destas intervenções, de 1972 até 1995. Um esquema a sequência dos procedimentos adotedos nesta fase é apresentada na Figura 24.

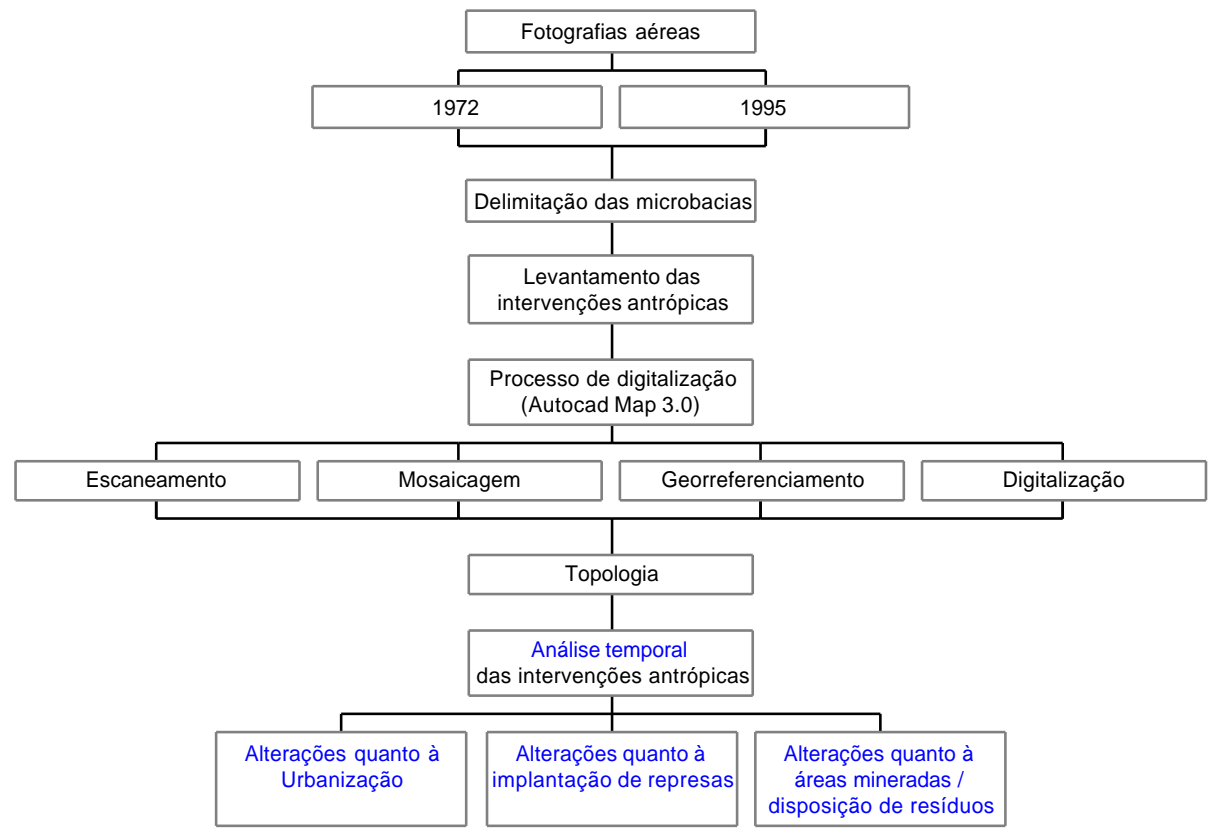

Figura 24: Sequência dos procedimentos adotada na análise temporal das intervenções antrópicas.

\section{5 - Resultados}

Após a efetivação do Mapa de Uso e Ocupação, as classes foram vetorizadas por meio de um recurso do programa ENVI $3.0^{\circledR}$, que transforma o arquivo da imagem classificada em uma série de arquivos do tipo DXF, cada um correspondente a uma classe. A sequência de comandos utilizada para esta operação foi a seguinte:

UTILITIES $\rightarrow$ VERTOR UTILITIES $\rightarrow$ RASTER TO VECTOR CONVERSION $\rightarrow$ "RASTER TO VERTOR INPUT BAND" $\rightarrow$ "RASTER TO VECTOR PARAMETERS" $\rightarrow$ (seleciona-se classes) $\rightarrow$ OK 
Os arquivos vetorizados puderam ser manipulados no programa Autocad Map $3.0^{\circledR}$, o que permitiu a determinação da área compreendida por cada uma das classes na bacia (Tabela 15) e por microbacias. Permitiu, também, o cruzamento destas informações com outras, obtidas por meio das análises efetuadas com as fotografias aéreas.

De acordo com a abrangência da área ocupada pelas classes em cada microbacia, elas foram classificadas por tipo de uso e ocupação predominante (Figura 25). Foram denominadas microbacias rurais aquelas onde mais de $70 \%$ da área estão ocupados por pastagem, cana de açúcar e/ou hortifruti, sendo que nas rurais - agrícolas mais de $70 \%$ da área está ocupado por cana de açucar e/ou hortifruti, nas rurais - não agrícolas mais de $70 \%$ da área está ocupado por pastagem e nas rurais - parcialmente agrícolas mais de $70 \%$ da área está ocupado por pastagem e culturas agrícolas, sem que haja o predomínio de uma sobre a outra. As microbacias urbanas foram assim denominadas quando a soma das classes centro urbano, ocupação mediamente adensada e ocupação pouco adensada, somadas, excederam $60 \%$ da área total e as microbacias mistas foram definidas como aquelas onde não houve um predomínio acentuado das classes rurais ou urbanas sobre o total de classes.

Tabela 15: Dados referentes à extensão das classes de uso e ocupação na bacia do rio Capivari.

\begin{tabular}{l|c|c}
\hline & Área $\left.\mathbf{( k m}^{2}\right)$ & Área (\% do total) \\
\hline Pastagem & 627,3 & 39,4 \\
Cana de açúcar & 537,8 & 34,0 \\
Hortifruti & 96,4 & 6,2 \\
Mata & 127,2 & 8,4 \\
Centros urbanos & 53,0 & 3,3 \\
Ocupação urbana mediamente adensada & 88,8 & 5,6 \\
Ocupação urbana pouco adensada & 31,7 & 2,0 \\
Área ocupada por represas & 9,7 & 0,6 \\
Áreas mineradas ou de disposição de lixo & 8,3 & 0,5 \\
Área total da bacia & 1581,2 & 100,0 \\
\hline
\end{tabular}




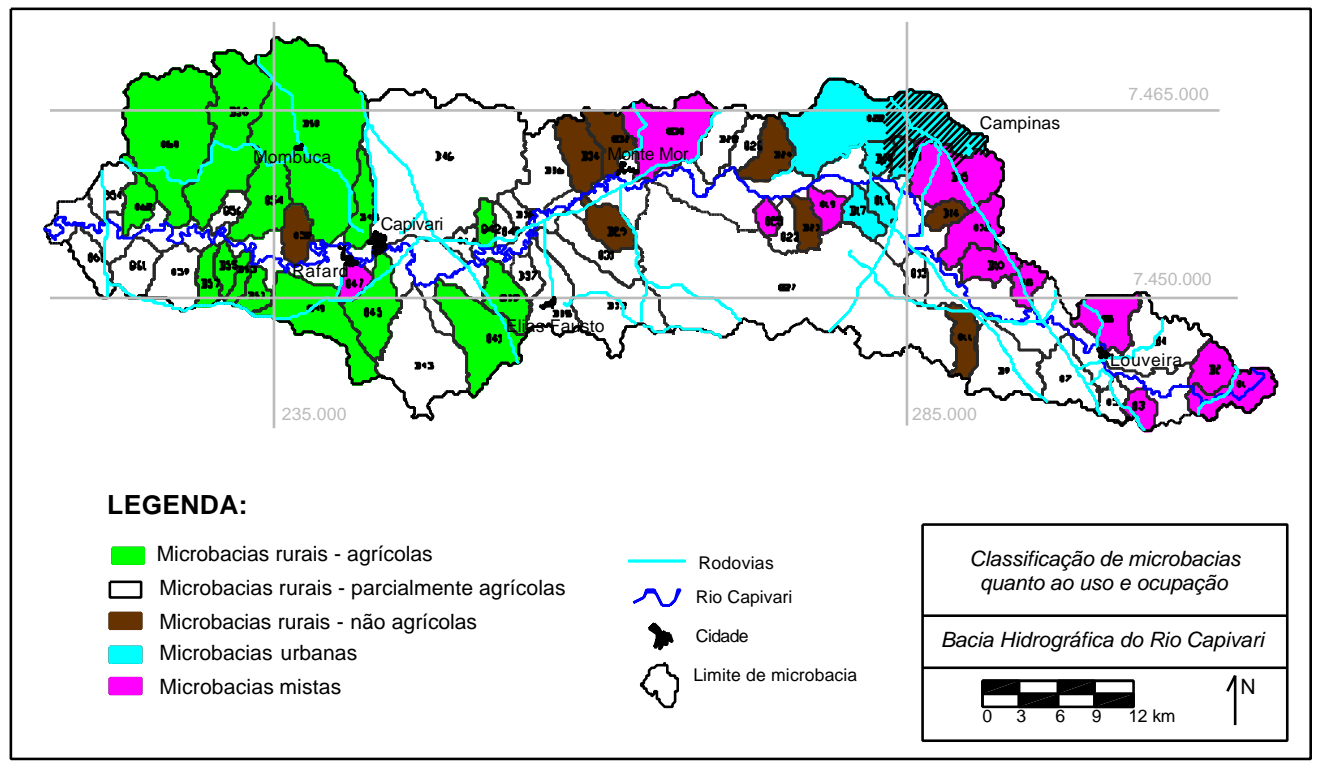

Figura 25: Classificação das microbacias da bacia do rio Capivari por predominância do tipo de uso e ocupação.

Uma análise combinada entre as classes vetorizadas e os dados obtidos com as fotografias aéreas nas datas de 1972 e 1995 permitiu quantificar o incremento da ocupação urbana e intervenções antrópicas no período (Tabela 16). Observa-se um crescimento bastante acentuado nas áreas urbanizadas, em torno de $380 \%$. A expansão urbana foi mais pronunciada na região periférica de Campinas, mais especificamente nas adjacências aos eixos rodoviários Rodovia Anhanguera (SP 330), Rodovia dos Bandeirantes (SP 348) e Rodovia Santos Drumont (SP 300) (Figura 26).

Tabela 16: Dados da bacia do rio Capivari referentes à análise temporal efetuada por meio do estudo comparativo de fotografias aéreas.

\begin{tabular}{|c|c|c|c|c|}
\hline & 1972 & 1995 & Variação & $\begin{array}{c}\text { Taxa de } \\
\text { variação } \\
(\%)\end{array}$ \\
\hline Área urbanizada $\left(\mathrm{km}^{2}\right)$ & 36,4 & 173,5 & 137,1 & 376.6 \\
\hline $\begin{array}{l}\text { Área minerada ou de disposição de } \\
\text { resíduos }\left(\mathrm{km}^{2}\right)\end{array}$ & 2,21 & 8,32 & 6,11 & 276,5 \\
\hline Área coberta por represas $\left(\mathrm{km}^{2}\right)$ & 4,87 & 9,68 & 4,81 & 98,8 \\
\hline Malha rodoviária $(\mathrm{km})$ & 179,3 & 336,1 & 156,8 & 87,5 \\
\hline Número de canais de $1^{\mathrm{a}}$ ordem & 14852 & 12992 & 1860 & $-12,5$ \\
\hline $\begin{array}{l}\text { Comprimento total dos canais de } 1^{\text {a }} \\
\text { ordem }(\mathrm{km})\end{array}$ & 2993,0 & 2888,1 & 104,9 & $-3,5$ \\
\hline $\begin{array}{l}\text { Comprimento total dos canais de } \\
\text { drenagem }(\mathrm{km})\end{array}$ & 5647,5 & 5337,6 & 309,9 & $-5,48$ \\
\hline
\end{tabular}




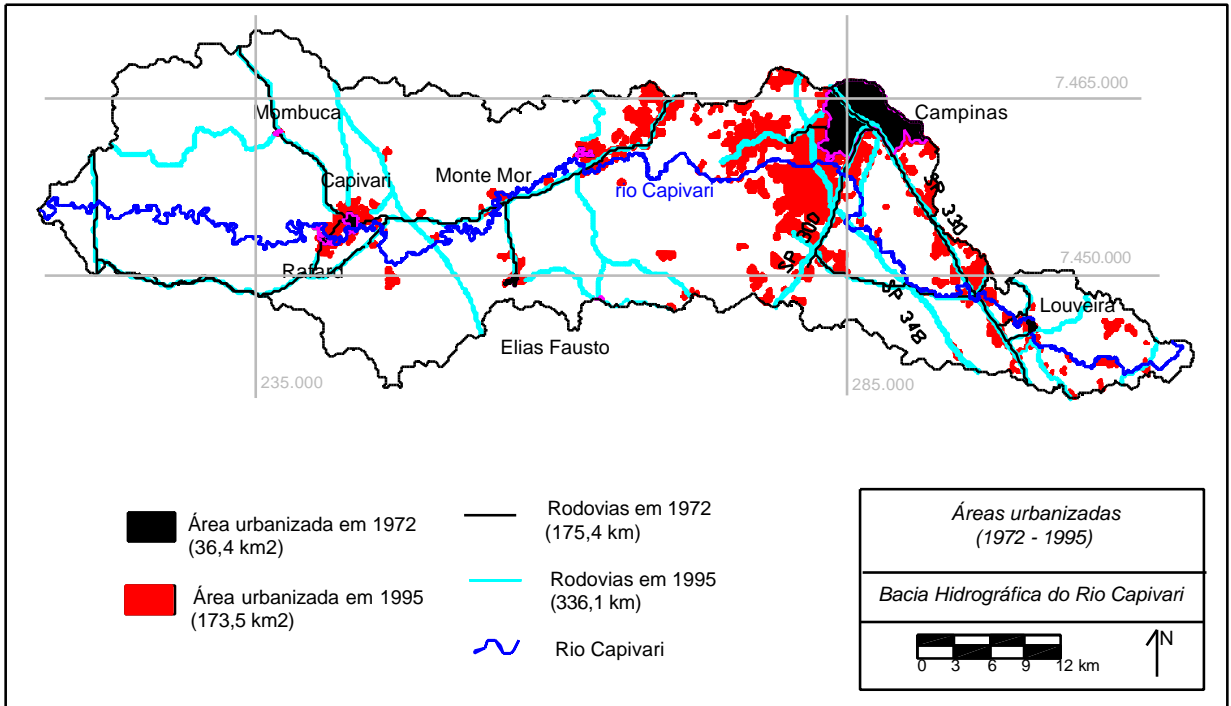

Figura 26: Áreas urbanizadas e rodovias na bacia do rio Capivari em 1972 e 1995.

As áreas alteradas por atividades de mineração e/ou disposição de resíduos, apesar de representarem uma área pouco significativa em relação à área total da bacia $(0,53 \%)$, normalmente são responsáveis por um alto potencial de degradação. No período entre 1972 e 1995 houve um aumento de 276,5 \% nas áreas cobertas por estes tipos de atividades (Figuras 27 e 28).

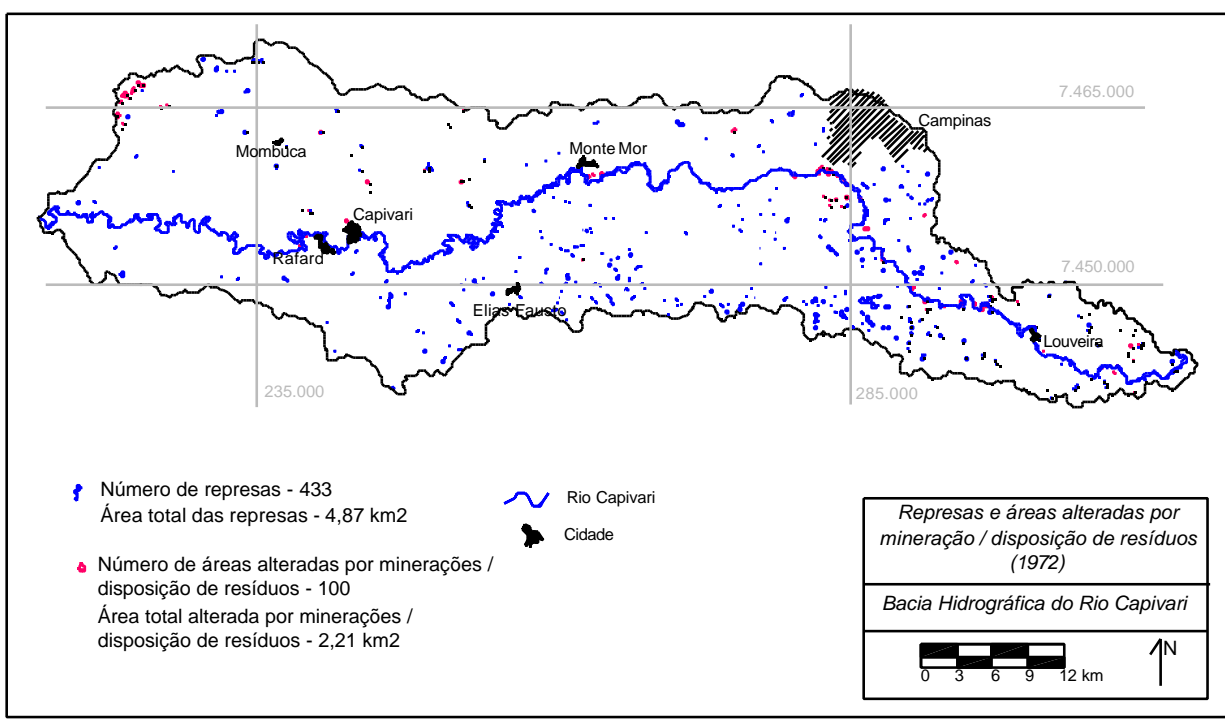

Figura 27: Represas e áreas alteradas por minerações e/ou disposição de resíduos na bacia do rio Capivari em 1972. 


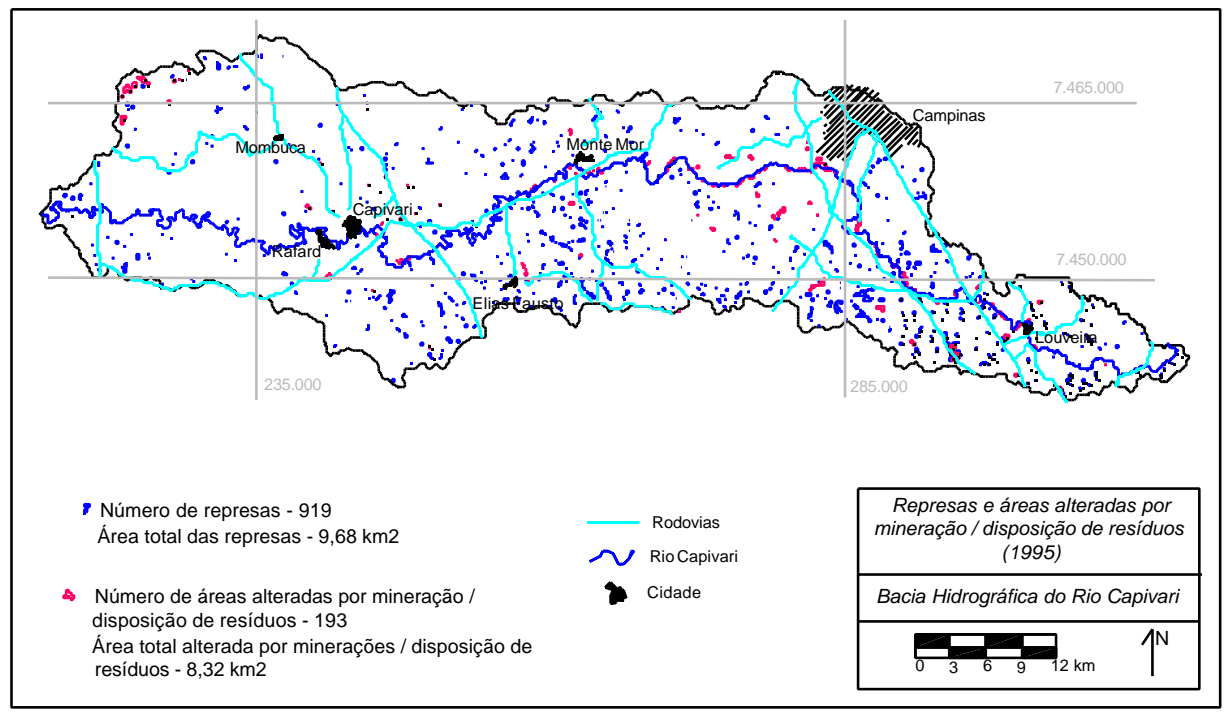

Figura 28: Represas e áreas alteradas por minerações e/ou disposição de resíduos na bacia do rio Capivari em 1995.

As microbacias com grandes áreas alteradas por atividades de mineração e/ou disposição de resíduos estão representadas na Figura 29 e na Tabela 17. As microbacias discriminadas foram aquelas onde as áreas alteradas são superiores a $1 \%$ da área total da bacia. Destas, as microbacias B47 e B20 apresentaram mais de $3 \%$ da área total cobertas por estas atividades. Uma grande concentração de áreas mineradas ocorre, também, em alguns setores nas margens do rio Capivari.

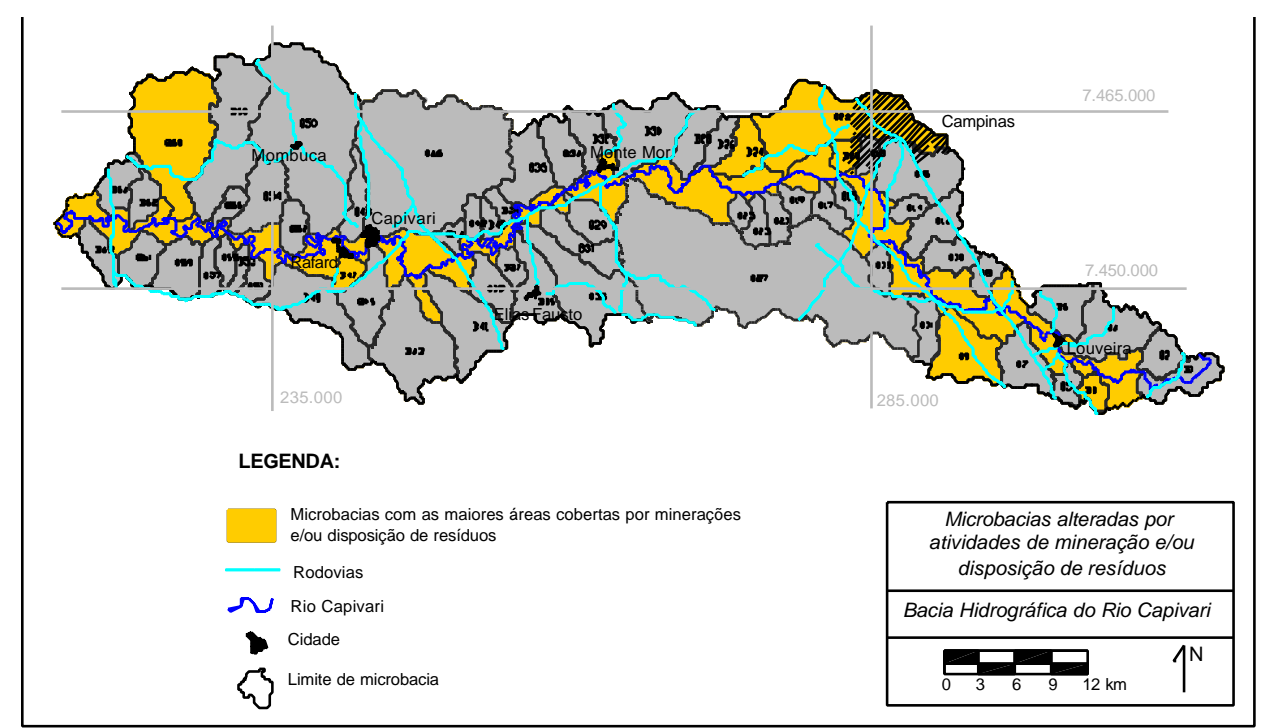

Figura 29: Microbacias da bacia do rio Capivari com as maiores áreas ocupadas por atividades de mineração e disposição de resíduos. 
Tabela 17: Áreas ocupadas por minerações e/ou disposição de resíduos nas microbacias mais significativas.

\begin{tabular}{l|l|l|l|l}
\hline Microbacia & $\begin{array}{l}\text { Área ocupada } \\
\text { em 1972 }(\mathrm{km})\end{array}$ & $\begin{array}{c}\text { \% da área total } \\
(1972)\end{array}$ & $\begin{array}{l}\text { Área ocupada } \\
\text { em 1995 }(\mathrm{km})\end{array}$ & $\begin{array}{c}\text { \% da área total } \\
(1995)\end{array}$ \\
\hline B3 & 0,00 & 0,00 & 0,12 & 2,00 \\
\hline B9 & 0,05 & 0,18 & 0,39 & 1,52 \\
\hline B20 & 0,09 & 1,61 & 0,21 & 3,77 \\
\hline B22 & 0,27 & 0,44 & 1,21 & 1,95 \\
\hline B24 & 0,04 & 0,35 & 0,24 & 1,87 \\
\hline B47 & 0,00 & 0,00 & 0,22 & 3,70 \\
\hline B60 & 0,43 & 0,69 & 0,96 & 1,54 \\
\hline Área do rio & 1,12 & 0,44 & 3,2 & 1,26 \\
\hline
\end{tabular}

As áreas ocupadas por represas constituem um parâmetro importante na análise das alterações uma vez que interferem no regime natural de escoamento das águas, além de promoverem alterações no terreno no momento de sua construção, como retirada de matas ciliares e remoção e/ou remobilização de solo.

As microbacias com grandes áreas cobertas por represas estão representadas na Figura 30 e na Tabela 18. As microbacias discriminadas foram aquelas onde estas áreas são superiores a 1\% da área total da bacia. Dentre todas, as que apresentaram maiores áreas cobertas por represas foram as microbacias B29, B10 e B9, onde as represas compreendem a mais de $1,8 \%$ da área total.

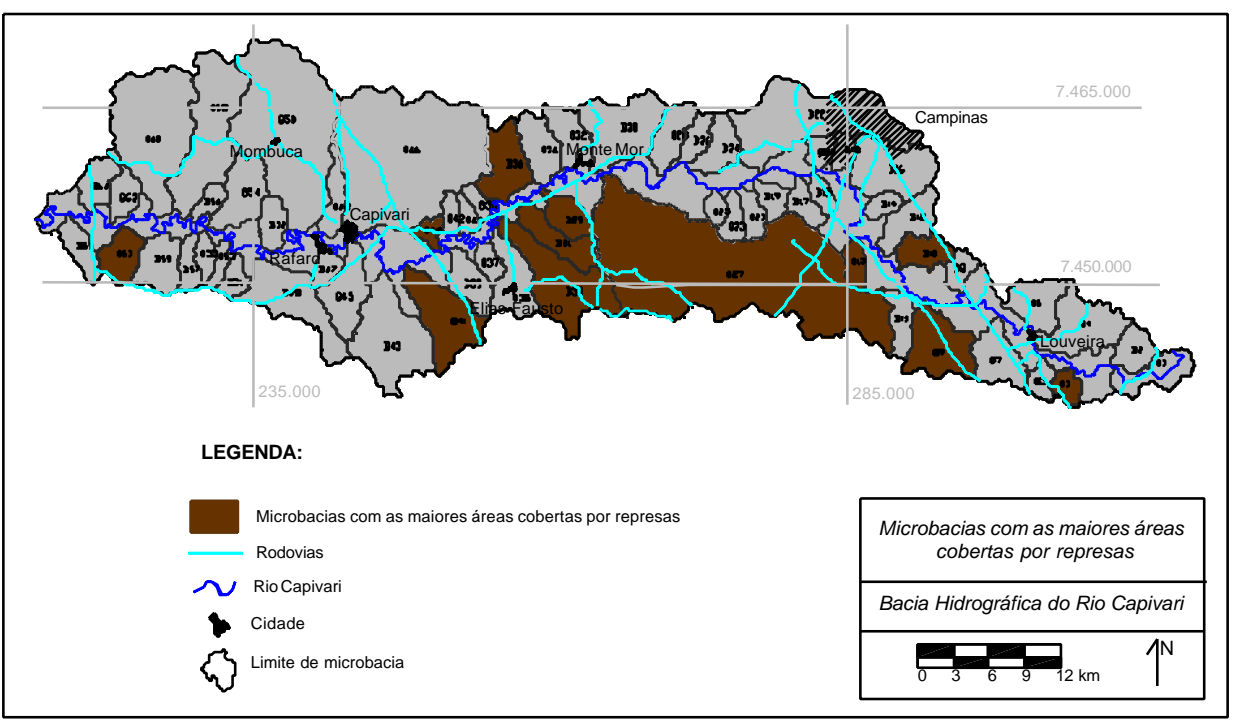

Figura 30: Microbacias com as maiores áreas ocupadas por represas. 
Tabela 18: Áreas ocupadas por represas nas microbacias mais significativas.

\begin{tabular}{l|l|l|l|l}
\hline Microbacia & $\begin{array}{l}\text { Área ocupada } \\
\text { em 1972 }(\mathrm{km})\end{array}$ & $\begin{array}{l}\text { \% da área total } \\
(1972)\end{array}$ & $\begin{array}{l}\text { Área ocupada } \\
\text { em 1972 }(\mathrm{km})\end{array}$ & $\begin{array}{l}\text { \% da área total } \\
(1995)\end{array}$ \\
\hline B3 & 0,04 & 0,64 & 0,07 & 1,14 \\
\hline B9 & 0,14 & 0,54 & 0,56 & 2,17 \\
\hline B10 & 0,09 & 0,24 & 0,20 & 1,82 \\
\hline B13 & 0,05 & 0,71 & 0,08 & 1,21 \\
\hline B27 & 1,90 & 1,01 & 2,70 & 1,44 \\
\hline B29 & 0,05 & 0,45 & 0,20 & 1,80 \\
\hline B31 & 0,13 & 0,84 & 0,24 & 1.49 \\
\hline B33 & 0,24 & 0,62 & 0,42 & 1,07 \\
\hline B36 & 0,01 & 0,02 & 0,23 & 1,14 \\
\hline B41 & 0,12 & 0,41 & 0,36 & 1,23 \\
\hline B44 & 0,00 & 0,00 & 0,06 & 1,42 \\
\hline B61 & 0,05 & 0,45 & 0,14 & 1,11 \\
\hline & & & & \\
\hline
\end{tabular}

\section{6 - Conclusões Parciais}

\subsection{1 - Quanto ao processamento das imagens de satélite e obtenção do Mapa de Uso e Ocupação}

As imagens de satélite Landsat-TM constituíram instrumento satisfatório na obtenção de um mapa de uso e ocupação, em escala regional. Vale ressaltar, entretanto, que para obtenção de mapas temáticos em escalas maiores, ou para a delineação de características superficiais do terreno, como o traçado da rede de drenagem de bacias hidrográficas, recomenda-se recursos de sensoriamento remoto com uma melhor resolução espacial. Não foi possível o traçado de canais de canais de drenagem de primeira ordem no processamento das imagens Landsat-TM, e assim, para a definição da rede de drenagem da bacia, foram utilizados pares estereoscópios de fotografias aéreas.

Quanto ao uso do programa ENVI 3.0 ${ }^{\circledR}$ no processamento das imagens, dois recursos merecem destaque. O primeiro refere-se à facilidade de manipulação dos diagramas de dispersão n-dimensionais. Este recurso mostrou-se útil tanto para a definição das amostras de treinamento da classificação não supervisionada, quanto 
para o refinamento das amostras de treinamento obtidas no levantamento de campo, que foram utilizadas na classificação supervisionada. O segundo recurso refere-se ao aplicativo Classedit que foi de grande utilidade para o refinamento da imagem classificada, permitindo a livre manipulação dos limites definidos pelas classes e a reclassificação dos pixels que haviam sido mal classificados.

Na definição das amostras de treinamento para o processo de classificação supervisionada, duas classes foram responsáveis por um mal resultado de classificação em uma primeira tentativa: a classe Cana de Açúcar, por apresentarse em vários estágios de maturação e a classe Centro Urbano, por apresentar uma alta dispersão nos níveis de cinza dos seus pixels.

Para solucionar estes problemas, optou-se por dividir a classe Cana de Açúcar em 3 sub-classes: cana pronta para o corte, cana em fase de amadurecimento e área preparada para o plantio de pana que, após o processo da classificação, foram reintegradas à uma única classe. Quanto a classe Centro Urbano, optou-se por suprimí-la do processo de classificação e reintegrá-la à imagem classificada, por meio do aplicativo Classedit.

\subsection{2 - Quanto ao levantamento pontual das atividades modificadoras do meio físico}

Este levantamento permitiu a observação direta e o georeferenciamento das principais fontes de degradação da bacia. Apesar de alguns órgãos públicos possuírem cadastros de algumas fontes específicas, estes dados normalmente se restringem aos limites municipais ou, em outros casos, não estão georeferenciados. De posse destes documentos, procurou-se avaliar e complementar estes dados com interpretação de fotografias aéreas e levantamento de campo.

A obtenção de um banco de dados georeferenciado com estes dados foi possível com o uso dos programas Access ${ }^{\circledR}$ e Autocad Map 3.0 ${ }^{\circledR}$. Os arquivos de dados foram construídos no Access ${ }^{\circledR}$ e, posteriormente foram acoplados à base georreferenciada com as imagens de satélite e mosaico de fotografias aéreas da bacia por meio do Autocad Map 3,0 ${ }^{\circledR}$. 


\subsection{3 - Avaliação das alterações no meio físico}

Alterações ocasionadas pelas atividades antrópicas, refletiram em um aumento em torno $380 \%$ nas áreas urbanizadas, motivado, principalmente, pela expansão da ocupação na cidade de Campinas e ao longo dos eixos rodoviários que cortam a porção leste da bacia. As áreas identificadas como mineradas ou de disposição de resíduos também sofreram um aumento superior a $270 \%$, estando as maiores concentrações situadas às margens do rio Capivari e nas microbacias B47 e B20. As áreas ocupadas por represas sofreram aumento em torno de $100 \%$ e as microbacias onde ocorrem as maiores concentrações de represas são BB29, B10 e B9. 


\section{5 - ANÁLISE MORFOMÉTRICA DAS REDES DE DRENAGEM DAS MICROBACIAS}

\section{1 - Considerações iniciais}

A rede de drenagem das bacias hidrográficas atua como registro das alterações ocorridas em seu interior e reflete as mudanças condicionadas por processos naturais ou atividades antrópicas, seja por meio das alterações na qualidade das águas ou na própria configuração da rede.

Alterações temporais, sejam por mudanças na sua estruturação, forma, ou mesmo pela perda ou aparecimento de novos canais faz da rede de drenagem um geoindicador das condições ambientais da bacia, uma vez que reflete a ocorrência de processos antrópicos ou naturais recentes, determinando uma nova dinâmica para o escoamento superficial das águas.

Os geoindicadores, conforme definição de Berger (1996), funcionam como um termômetro na medida dos processos e fenômenos do meio físico que ocorrem em períodos curtos (menos de 100 anos) e refletem as alterações ambientais do sistema. Neste contexto, a avaliação da composição da rede de drenagem em microbacias que constituem uma bacia hidrográfica deverá permitir a identificação das áreas com maior grau de alteração e assim contribuir para a definição de uma sequência de prioridades na gestão da bacia e elaboração de um plano de ações.

Neste capítulo é avaliada a significância das alterações ocorridas nas microbacias que compõem a bacia do rio Capivari, com base em variáveis morfométricas de suas redes de drenagem. Posteriormente, as microbacias são agrupadas conforme o nível de alteração a que estiveram submetidas. As análises das alterações são referentes a um período de 23 anos e foram efetuadas com 0 uso das fotografias aéreas datadas de 1972 e 1995. 
A hierarquização dos canais nas redes de drenagem foi efetuada conforme a classificação proposta por Strahler (1957) com modificações, uma vez que este autor utiliza apenas os canais de curso permanente. Nesta pesquisa, considerou-se como canais de drenagem todos aqueles perceptíveis nas fotografias aéreas que permitissem o escoamento linear das águas, incluindo os de curso intermitente, uma vez que estes canais constituem uma variável importante para o fluxo das águas na bacia e são os mais suscetíveis a alterações.

Para a determinação das variáveis morfométricas, as redes de drenagem foram digitalizadas, georreferenciadas e transformadas em topologia com o auxílio do programa Autocad Map3.0 ${ }^{\circledR}$. O uso de entidades vetoriais para a obtenção das variáveis morfométricas, em detrimento da sua obtenção por meio de SIGs, com imagens rasterizadas, deveu-se à maior praticidade e precisão do sistema vetorial.

Civco et al (1995) já haviam discutido esta questão ao avaliar imagens raster e vetoriais para a obtenção de parâmetros de bacias hidrográficas. Segundo estes autores, dados vetoriais são mais precisos, principalmente para a obtenção de dados poligonais e advertem sobre a possibilidade de geração de erros nas transformações de dados raster para vetoriais.

No total, foram determinadas vinte variáveis, relativas à morfologia e à composição da rede de drenagem. Apenas as variáveis relativas à composição da rede de drenagem foram utilizadas nas avaliações das alterações temporais uma vez que as variáveis relativas à morfologia não se alteram, considerando-se o período de análise.

Utilizou-se procedimentos estatísticos multivariados, com auxílio do programa Statistica $5.5^{\circledR}$, para avaliar a significância das alterações ocorridas nas microbacias e agrupá-las conforme o grau de alteração. Para o teste de significância, utilizou-se o processo estatístico da análise discriminante e para o agrupamento das microbacias conforme o grau de alteração, a análise de agrupamentos. 


\section{2 - Análise morfométrica de bacias hidrográficas - uma revisão}

Datam do início do século XIX as primeiras interpretações descritivas referentes a sistemas de drenagens. Playfair (1802, apud Horton, 1945), com base em observações visuais, relatou as relações do tronco principal de um rio e os seus tributários, formando um conjunto de canais e vales comunicantes, determinando, assim, a "lei das junções concordantes".

Horton (1945), com base na lei de Playfair, utilizou pela primeira vez uma análise quantitativa em sistema de drenagem, estabeleceu um sistema para classificação de canais em uma rede hidrográfica e determinou novas leis fundamentais relacionando o número e o comprimento de canais.

Pelo sistema de classificação de canais de Horton (1945) os canais de primeira ordem são aqueles que não possuem tributários; os de segunda ordem só recebem tributários de primeira ordem; os de terceira ordem podem receber tributários de primeira e segunda ordens; e assim sucessivamente. O rio principal é representado pelo canal de maior ordem, permanecendo com este valor hierárquico da sua nascente até a foz.

Esse procedimento se contrapôs ao sistema mais difundido até então, o sistema europeu de classificação de rios. Pelo sistema europeu, o rio principal ou tronco é designado como de primeira ordem, seus tributários imediatos de segunda ordem e assim sucessivamente até chegar aos tributários não ramificados, denominados como os de ordem mais elevada.

Com a análise quantitativa em sistemas de drenagens, Horton (1945) estabeleceu os índices razão de bifurcação e razão entre comprimentos médios. Pela razão de bifurcação relacionou o número de canais de uma determinada ordem com o número de canais de ordem imediatamente superior e estabeleceu a "lei do número de canais" como uma série geométrica inversa cujo primeiro termo é a unidade de primeira ordem e a razão é a razão de bifurcação. Pela razão entre comprimentos médios, relacionou o comprimento médio dos canais de uma determinada ordem com o comprimento médio dos canais de ordem imediatamente 
inferior e estabeleceu a "lei dos comprimentos de canais" como uma série geométrica direta cujo primeiro termo é o comprimento médio dos canais de primeira ordem e a razão é a razão entre os comprimentos médios.

Strahler (1957) utilizou um sistema de classificação de canais com algumas modificações com relação ao sistema definido por Horton. Pelo sistema de Strahler, os canais sem tributários são considerados como de primeira ordem; da confluência de dois canais de primeira ordem surgem os canais de segunda ordem, e assim sucessivamente, sendo a ordem da bacia hidrográfica correspondente ao valor do canal de maior ordem. Este procedimento elimina o conceito de que o rio principal deva ter o mesmo número de ordem da nascente até a foz, como proposto por Horton, e facilita a classificação dos canais, eliminando a necessidade de se refazer a ordenação a cada confluência. Esta forma de classificação tem sido amplamente utilizada em todo o mundo na análise morfométrica de bacias hidrográficas.

Além das variáveis Razão de Bifurcação e Razão de Comprimento Médio definidas por Horton (1945), outras já haviam sido definidas e utilizadas anteriormente, tais como Densidade de Drenagem, que expressa a relação entre o comprimento total de rios das diversas ordens e a área da bacia de drenagem e Densidade hidrográfica, então chamada de Frequência de Rios, que relaciona o número total de rios, que, pela classificação de Strahler (1957) corresponde ao número de canais de primeira ordem e a área da bacia.

Ao estudar a evolução de sistemas de drenagens, Schumm (1956) definiu as variáveis coeficiente de manutenção e relação de relevo. O coeficiente de manutenção representa a área mínima necessária em uma bacia para manter em funcionamento um metro de canal de escoamento. Nesta concepção, conforme vai ocorrendo a dissecação do relevo, vai diminuindo a área disponível para entalhamento dos canais, determinando uma correlação inversa entre os valores de coeficiente de manutenção com os de densidade de drenagem e densidade hidrográfica. A relação de relevo foi definida como a relação existente entre a amplitude altimétrica de uma bacia e o seu maior comprimento. Desta forma, quanto mais elevados os valores, maior o desnível entre cabeceira e foz e maior a declividade média da bacia. 
Strahler (1957) propôs uma primeira classificação para as variáveis estabelecidas até então e definiu duas classes de variáveis: as variáveis que expressam dimensões de comprimento e seus produtos e as variáveis adimensionais. Dentre as variáveis que expressam dimensões de comprimento, incluem-se os comprimentos de canais de rios de uma dada ordem, comprimento médio dos canais, o perímetro e a área da bacia. As variáveis adimensionais se relacionam geralmente com ângulos e razões de medidas de comprimento, tais como, razão de bifurcação, razão de comprimento médio, ângulos de junção, número de canais por ordem e propriedades referentes ao relevo.

Considerando esta classificação e o principio da similaridade para comparações entre bacias de drenagem, Strahler (1957) estabeleceu que para bacias geometricamente semelhantes todas as dimensões de comprimento correspondentes deverão apresentar uma razão constante e todas as variáveis adimensionais correspondentes deverão apresentar valores idênticos, mesmo que haja diferenças em seus tamanhos.

Christofoletti (1969 e 1974) agrupou as variáveis morfométricas conforme seus aspectos lineares, areais e hipsométricos. As variáveis lineares referem-se às medições efetuadas ao longo das linhas de escoamento e incluem a razão de bifurcação, razão entre comprimentos médios, comprimento do rio principal e extensão do percurso superficial. As variáveis areais envolvem medições planimétricas, além de medições lineares e incluem a área e o comprimento da bacia, o índice de circularidade, a densidade hidrográfica, a densidade de drenagem e o coeficiente de manutenção. As variáveis hipsométricas envolvem inter-relações existentes entre unidades lineares e planimétricas e suas relações com as variações altimétricas e incluem a amplitude altimétrica máxima da bacia, a relação de relevo e o índice de rugosidade.

No Brasil, Gandolfi (1968 e 1971) aplicou a análise morfometrica para a caracterização sedimentológica e geomorfológica de bacias hidrográficas no interior do Estado de São Paulo. O autor agrupou as variáveis segundo a forma (índice de forma, relação de relevo, densidade hidrográfica, e densidade de drenagem), os componentes da rede hidrográfica (coeficiente de manutenção, extensão do percurso superficial, gradiente dos canais), a textura topográfica, a ordem dos 
canais (razão de bifurcação, razão ponderada de bifurcação) e os ângulos de junção. Para estabelecer relações entre as bacias estudadas utilizou análise estatística, por meio da determinação dos coeficientes de correlação linear.

França (1968) utilizou a análise morfométrica no estudo de solos da região de Piracicaba - SP e conclui que a composição e as características do padrão de drenagem variam, em primeiro lugar, com a natureza do solo e, em menor peso, com a posição topográfica e com a natureza e profundidade do substrato rochoso. Dentre os elementos da drenagem que permitiram fazer a distinção entre os solos destacaram-se as seguintes variáveis: razão de bifurcação, o comprimento médio dos canais, a razão de comprimentos médios, a razão de textura média e a densidade de drenagem.

Após o trabalho de França (1968), várias pesquisas em nível de mestrado e doutorado passaram a ser desenvolvidas na Escola Superior de Agricultura "Luiz de Queiroz" da Universidade de São Paulo com o objetivo de incorporar o uso de fotografias aéreas e análise morfométrica na distinção de unidades de solos. Dentre estas pesquisas estão: Demétrio (1977), Carvalho (1977), Politano (1980), Angulo Filho (1981), Angulo Filho (1986), Lima (1987) e Silva (1993).

Demétrio (1977) estudou a variação de parâmetros como a densidade de drenagem e densidade hidrográfica em função da escala de fotografias aéreas verticais. $O$ autor concluiu que as variações foram significativas para as duas variáveis, sendo mais pronunciada na densidade hidrográfica.

Angulo Filho (1981) estudou, na região de Piracicaba - SP, a variação dos mesmos parâmetros em função de fotografias aéreas verticais obtidas em épocas distintas. O período estudado compreende ao da expansão da cana de açúcar na região e o autor observou, na maior parte dos casos, variações ascendentes nos valores de densidade de drenagem e densidade hidrográfica.

Os trabalhos de Carvalho (1977), Politano (1980), Angulo Filho (1986), Lima (1987) e Silva (1993) retratam a influência de parâmetros morfométricos na distinção de unidades de solos do interior do Estado de São Paulo utilizando, na maior parte dos casos, procedimentos estatísticos simples como comparação entre 
médias, erro padrão das médias e análise de variância. Tanto os índices relativos à drenagem quanto os índices do relevo mostraram-se eficientes na diferenciação.

Outros trabalhos, também relacionados às ciências agrárias, como Piedade el al (1984), Politano et al. (1991, 1994 e 1995) e Barros et al. (1991 e 1996) aplicam diferentes formas de análises estatísticas na avaliação dos dados morfométricos para distinção entre microbacias hidrográficas e unidades de solos.

Piedade et al. (1984) utilizaram-se do teste de similaridade geométrica proposto por Strahler (1957) para agrupar bacias semelhantes e coeficientes de correlação e de regressão múltipla para verificar a interdependência entre as variáveis morfométricas.

Politano et al. (1991) aplicaram técnicas de estatística não paramétrica, utilizando análise de variância por meio do teste de Friedman e comparações múltiplas para distinção de unidades de solo com base em variáveis morfométricas. Em Politano et al (1994 e 1995) foram utilizados métodos estatísticos básicos (média, erro padrão da média e coeficiente de variação) e análise de regressão linear e múltipla; no primeiro trabalho para avaliar a influência de índices do relevo no desenvolvimento de bacias hidrográficas e no segundo para avaliar as relações morfométricas entre bacias hidrográficas de diferentes ordens.

Barros et al. (1991 e 1996) aplicaram a análise estatística multivariada, por meio das técnicas de análise de agrupamento, para verificar a semelhança geométrica entre as bacias e a análise das componentes principais para identificar as variáveis que mais contribuem para a discriminação entre as bacias.

Trabalhos mais recentes têm procurado adequar as análises morfométricas por meio de técnicas de geoprocessamento. Dentre eles estão: Band (1989), Civco et al (1995), Meisels et al (1995), Sheng et al (1997) e Garbrecht \& Martz (1997). Estes trabalhos discutem e propõem técnicas que permitem a obtenção de redes de drenagem automaticamente, com o uso de imagens de satélite e sistemas de informações geográficas. 
No Brasil, alguns trabalhos nesta linha foram efetuados por Ferreira (1997 e 1999) e Souza (2000). Ferreira (1997) utilizou Modelo Digital do Terreno (MDT) para extração de índices do relevo, tais como, amplitude altimétrica, altitude média, desvio padrão das altitudes e coeficiente de dissecação e Ferreira (1999) propôs uma técnica para interpretar a variabilidade da densidade de drenagem dentro de uma bacia hidrográfica. Souza (2000) estudou a viabilidade do uso de técnicas de geoprocessamento em fotografias aéreas digitalizadas para o traçado de redes de drenagem na tela do computador, em substituição ao processo manual com o uso de estereoscópios.

O uso de parâmetros morfométricos e análise de sua influência na caracterização ambiental de bacias hidrográficas foram efetuados por Prochnow (1990) e Fontes (1997). Prochnow (1990) levantou variáveis de cunho geométrico e geomorfológico em cinco bacias da bacia do Piracicaba, dentre as quais deu mais importância para a densidade de drenagem e índice de sinuosidade. Fontes (1997) utilizou-se de um grande número de variáveis lineares e de superfície e as aplicou no macrozoneamento geoambiental de uma bacia hidrográfica.

A aplicação de estatística multivariada em uma avaliação ambiental, envolvendo variáveis morfométricas e geomorfológicas, foi efetuada por WoodSmith \& Buffington (1996) na avaliação do impacto do uso do terreno nas condições dos canais de drenagem no sudoeste do Alaska - EUA. Os autores utilizaram-se de análise discriminante para testar a classificação previamente adotada para rios degradados e não degradados e ainda determinar as variáveis que mais contribuíram para a discriminação entre os rios.

Ferreira (1996) ao propor uma metodologia para a classificação de pequenas bacias hidrográficas quanto a características hidrológicas, com base na cobertura vegetal, pedologia e parâmetros morfométricos, utilizou-se de técnicas estatísticas multivariadas. A análise de agrupamento foi utilizada para agrupar bacias com características semelhantes e a análise discriminante (teste F) para verificar se a distinção entre os grupos foi realmente significativa.

\section{3 - Descrição das variáveis morfométricas}


Nesta pesquisa, por se tratar de um estudo comparativo envolvendo as alterações internas ocorridas em um sistema (microbacias hidrográficas) durante um determinado período, as variáveis morfométricas analisadas foram separadas em dois grupos: variáveis relativas à morfologia, denominadas de variáveis morfológicas e variáveis relativas à composição da rede de drenagem, denominadas variáveis da rede de drenagem.

As variáveis morfológicas foram consideradas inalteradas para uma mesma microbacia dentro do período analisado e portanto não foram aplicadas diretamente na análise das alterações ocorridas no período. As variáveis que compõem este grupo são: Área $(\mathrm{A})$ e perímetro $(\mathrm{P})$, maior comprimento $(\mathrm{L})$, largura média $(\mathrm{dm})$, índice de circularidade (Ic), amplitude altimétrica máxima $(\mathrm{Hm})$, relação de relevo (Rr) e índice de sinuosidade (Si).

As variáveis da rede de drenagem envolvem variáveis lineares e de superfície e consistem naquelas sujeitas à variações no período analisado, constituindo, portanto, em parâmetros potenciais para retratar as alterações ocorridas. Fazem parte deste grupo: número total de rios (N1), número de canais por ordem (Ni), comprimento total da rede de drenagem (Lt), comprimento total dos canais por ordem (Li), comprimento médio dos canais por ordem (Lmi), razão de bifurcação $(\mathrm{Rb})$, razão de comprimento médio (RIm), densidade de drenagem (Dd), densidade hidrográfica (Dh), coeficiente de manutenção $(\mathrm{Cm})$, extensão do percurso superficial (Eps) e textura topográfica $(\mathrm{Tt})$.

a) Área $(\mathrm{A})$ e perímetro $(\mathrm{P})$

Constituem parâmetros básicos utilizados para o cálculo de outras variáveis morfométricas e são definidos com base na linha que delimita o divisor de águas das bacias. A área é expressa em $\mathrm{km}^{2}$ e o perímetro em $\mathrm{km}$.

b) Maior comprimento (L) e largura média (dm)

Estas duas variáveis, expressas em km, foram determinadas utilizando-se os critérios adotados por Fontes (1997), onde o maior comprimento é representado 
pelo comprimento do maior eixo longitudinal da bacia e a largura média é resultante da divisão da área pelo maior comprimento.

c) Índice de circularidade (Ic)

Este índice foi inicialmente proposto por Miller (1953 apud Christofoletti, 1974) e é definido como a relação existente entre a área da bacia $(A)$ e a área do círculo de igual perímetro (Ac).

$$
\mathrm{Ic}=\frac{\mathrm{A}}{\mathrm{Ac}}
$$

O índice de circularidade tem significado semelhante ao índice de forma (Chiristofoletti, 1969 e Tavares \& Queiroz, 1981), ao coeficiente de compacidade (Villela \& Mattos, 1980) e à relação de elongação (Schumm, 1956) que correlacionam o perímetro da bacia com a sua área. As quatro variáveis indicam que à medida que o valor encontrado se aproxima da unidade $(\mathrm{IC}=1,0)$ a bacia tende à forma circular.

Segundo Morisawa (1962), o índice de circularidade, em combinação com a densidade hidrográfica e o gradiente do relevo deverá determinar o fator topográfico, que é a componente morfométrica da bacia influente em processos de inundação. O fator topográfico é definido pela seguinte equação:

$\mathrm{Ft}=\mathrm{Dh} \cdot \mathrm{Ic} \cdot \mathrm{Rr}$

Onde:

$\mathrm{Ft}$ - fator topográfico

Dh - densidade hidrográfica

Ic - índice de circularidade

$\mathrm{Rr}$ - relação de relevo

d) Amplitude altimétrica máxima $(\mathrm{Hm})$ e relação de relevo $(\mathrm{Rr})$

Estas duas variáveis foram apresentadas inicialmente por Schumm (1956) e estão relacionadas com as variações topográficas da bacia. A amplitude altimétrica máxima corresponde à diferença altimétrica, em metros, entre a altitude da 
desembocadura e a altitude do ponto mais alto no divisor de águas. Os valores altimétricos para as microbacias analisadas foram retirados de mapas topográficos do IBGE (IBGE, 1970a; IBGE,1970b; IBGE, 1970c; IBGE, 1970d; IBGE, 1971; IBGE, 1973a; IBGE, 1973b; IBGE, 1974).

A relação de relevo $(\mathrm{Rr})$ relaciona a amplitude altimétrica máxima $(\mathrm{Hm})$ com o seu maior comprimento (L), indicando que quanto mais elevado o valor de $\mathrm{Rr}$, maior o desnível entre a cabeceira e foz. A relação de relevo pode ser definida pela seguinte expressão:

$$
\mathrm{Rr}=\underline{\mathrm{Hm}}
$$

$\mathrm{L}$

Morisawa (1962) utilizou-se desta variável para preencher a componente relativa ao relevo na determinação do fator topográfico o qual indica se a bacia apresenta características favoráveis ou não a inundações. Os estudos efetuados por Patton \& Baker (1976) em bacias com alto e baixo potenciais à inundações indicaram a relação de relevo como uma das três variáveis morfométricas (também incluem densidade de drenagem e ordem dos canais) mais influentes na indicação de bacias com alto potencial à inundação.

Originalmente, Schumm (1956) a utilizou como uma variável adimensional, expressando os valores de $\mathrm{Hm}$ e $\mathrm{L}$ na mesma dimensão. Alguns trabalhos mais recentes, como Gandolfi (1968) e Fontes (1997), que fizeram uso desta variável, preferiram manter $\mathrm{Hm}$ e $\mathrm{L}$ em suas dimensões originais, metros e quilômetros, respectivamente. Nesta pesquisa, optou-se, também, por manter as dimensões originais de $\mathrm{Hm}$ e $\mathrm{L}$ e expressar os valores de $\mathrm{Rr}$ em m/km.

e) Índice de sinuosidade (Si)

Trata-se da relação entre o comprimento do rio principal da bacia e o seu comprimento vetorial e pode ser calculado pela seguinte fórmula:

$$
\mathrm{Si}=\mathrm{L}_{\text {rio }} / \mathrm{L}_{\text {vet }}
$$


Onde:

$\mathrm{L}_{\text {rio }}$ - comprimento do rio principal e

$\mathrm{L}_{\mathrm{vec}}$ - comprimento vetorial do rio principal.

Segundo Villela e Mattos (1975) este índice, que descreve o grau de sinuosidade ou divagação dos cursos d'água, constitui um fator controlador da velocidade de escoamento das águas.

f) Número total de rios $\left(\mathrm{N}_{1}\right)$ e número de canais por ordem de ramificação $(\mathrm{Ni})$

As variáveis correspondentes ao número de canais, além de permitirem uma avaliação primária das alterações ocorridas na bacia (perda ou ganho de canais), são particulamente importantes quando se analisa suas inter-relações, por meio da razão de bifurcação.

O número total de rios, quando da utilização do sistema de ordenação de Strahler, corresponde ao número de canais de primeira ordem $\left(\mathrm{N}_{1}\right)$, uma vez que qualquer rio surge de uma nascente. Esta variável é particularmente importante para o cálculo da densidade hidrográfica.

g) Comprimento total da rede de drenagem (Lt), comprimento total dos canais por ordem (Li) e comprimento médio dos canais por ordem (Lmi)

São variáveis dimensionais, expressas em quilômetro $(\mathrm{km})$ ou em metro $(\mathrm{m})$, que permitem uma avaliação primária das alterações em termos de perda ou ganho na extensão de caminhos para o escoamento linear das águas na bacia. Nesta pesquisa as variáveis Lt e Li foram expressas em $\mathrm{km}$ e a variável Lmi, em m.

h) Razão de bifurcação (Rb)

Variável introduzida por Horton (1945) e que deu origem à lei do número de canais. Expressa a relação entre o número de canais de uma certa ordem $\left(\mathrm{N}_{\mathrm{i}}\right)$ e o número de canais da ordem imediatamente superior $\left(\mathrm{N}_{\mathrm{i}+1}\right)$ : 
$\mathrm{Rb}=\frac{\mathrm{N}_{\mathrm{i}}}{\mathrm{N}_{\mathrm{i}+1}}$

Straher (1957) corroborou com as afirmações de Horton referente à lei do número de canais e complementou dizendo que se trata de um índice altamente estável, apresentando uma pequena amplitude de variação de uma região para outra ou de um ambiente para outro. França (1968) observou valores de Rb mais altos para bacias com solo menos permeáveis e vice-versa.

i) Razão de comprimento médio (RIm)

Esta variável também foi introduzida por Horton (1945), deu origem à lei do comprimento dos canais. O índice é expresso pela relação entre o comprimento médio dos canais de determinada ordem $\left(\mathrm{Lm}_{\mathrm{i}}\right)$ e o comprimento médio dos canais da ordem imediatamente inferior $\left(\mathrm{Lm}_{\mathrm{i}-1}\right)$ :

$$
R_{L m}=\frac{L m_{i}}{L m_{i-1}}
$$

A razão de bifurcação e a razão de comprimento médio, apesar de serem variáveis pouco utilizadas em análises geoambientais por se tratarem de parâmetros que apenas refletem a estruturação interna dos canais na bacia, são de grande validade quando utilizadas em análises temporais comparativas, como é o caso desta pesquisa. Os valores correspondentes às mudanças ocorridas no período de análise (taxa de perda ou de ganho expressa em porcentagem), podem indicar alterações internas nas bacias, mesmo quando estas não apresentam variações no número de canais ou em variáveis dimensionais.

\section{j) Densidade de drenagem (Dd)}

A variável retrata as disponibilidade de canais para o escoamento linear das águas e materiais detríticos e o grau de dissecação do relevo resultante da atuação da rede de drenagem. Foi descrita por Horton (1945) como sendo a relação entre o comprimento total dos canais ( $\mathrm{Lt}$ ) pela área da bacia hidrográfica (A). No comprimento dos canais, segundo Christofoletti (1969), deve-se considerar os 
canais perenes e intermitentes. A fórmula para o cálculo da densidade de drenagem é a seguinte:

$$
\mathrm{Dd}=\frac{\mathrm{Lt}}{\mathrm{A}}
$$

Segundo Horton (1945) as bacias de menor porte e de grau hierárquico menor tendem a apresentar valores de Dd mais elevados. Christofoletti (1979) explicou este fato com o argumento de que os segmentos de ordens inferiores estão nos setores mais altos dos cursos d'água, onde as declividades são mais acentuadas; conforme aumenta a área da bacia e a ordem da rede hidrográfica, incorporam-se áreas topograficamente mais suaves, dando origem a espaços com densidade de drenagem baixa.

Christofoletti (1969) utilizou a seguinte classificação para a densidade de drenagem em bacias hidrográficas:

$$
\begin{aligned}
& \text { Dd }<7,5\left(\mathrm{~km} / \mathrm{km}^{2}\right) \text { - Baixa } \\
& \text { Dd 7,5-10 }\left(\mathrm{km} / \mathrm{km}^{2}\right) \text { - Média } \\
& \text { Dd }>10\left(\mathrm{~km} / \mathrm{km}^{2}\right) \text { - Alta }
\end{aligned}
$$

Conforme Christofoletti (1974), em terrenos onde há dificuldades para a infiltração das águas há melhores possibilidades para a esculturação de canais e, portanto, Dd tende a ser mais elevado. Além da geologia, outros fatores do meio físico podem influenciar tais como, topografia, clima e vegetação.

Com relação aos fatores antrópicos, incluindo urbanização, agricultura, indústria, manejo de florestas e turismo, segundo FAO (1995), apenas a urbanização e a agricultura são capazes de provocar alterações consideráveis na densidade de drenagem em uma bacia hidrográfica.

\section{J) Densidade Hidrográfica (Dh)}

Foi inicialmente definida por Horton (1945) com a denominação de frequência de rios e corresponde à relação entre o número de rios ou cursos d'água e a área da bacia hidrográfica (A). Quando da utilização do sistema de ordenação 
de canais proposto por Strahler (1957), o número de rios deve corresponder ao número de canais de primeira ordem $\left(\mathrm{N}_{1}\right)$, considerando que todo rio se inicia de uma nascente. A densidade hidrográfica é expressa pela seguinte expressão:

$\mathrm{Dh}=\frac{\mathrm{N}_{1}}{\mathrm{~A}}$

Christofoletti (1974) considerou Dh uma variável de grande importância por representar o comportamento hidrológico de uma determinada área em um dos seus aspectos fundamentais, que é a capacidade de gerar novos cursos d'água. Em se tratando das alterações antrópicas a que uma bacia possa estar submetida, variações temporais nos valores de Dh devem refletir modificações nas demais variáveis morfométricas ou mesmo na ordem hierárquica da bacia.

Morisawa (1962) utilizou-se da densidade hidrográfica como uma das variáveis na determinação do fator topográfico, que indica se a bacia apresenta características favoráveis ou não à inundações.

K) Coeficiente de manutenção $(\mathrm{Cm})$

Esta variável foi definida por Schumm (1956) para fornecer a área mínima necessária em uma bacia para manter em funcionamento um metro de canal de escoamento. A variável pode ser calculada pela seguinte expressão:

$\mathrm{Cm}=\frac{1}{\mathrm{Dr}} \cdot 1000$

Pela expressão observa-se uma correlação inversa com a densidade de drenagem, indicando que a medida que vai aumentando a dissecação do relevo, vai diminuindo a área disponível para o entalhamento de novos canais, ou seja, o coeficiente de manutenção indica a área média que permanece isenta de entalhes. A multiplicação por 1000 que aparece na expressão justifica-se para que o valor possa ser expresso em $\mathrm{m}^{2} / \mathrm{m}$, ou seja, quantidade de área para cada metro de canal. 
I) Extensão do percurso superficial (Eps)

A variável foi apresentada por Horton (1945) e representa a distância média (expressa em metros) percorrida pelas águas pluviais, a partir do interflúvio, até encontrar um canal já delineado. Esta variável pode ser calculada utilizando a seguinte expressão:

$\mathrm{Eps}=\frac{1}{2 \cdot \mathrm{Dd}} \cdot 1000$

m) Textura Topográfica (Tt)

Esta variável define o grau de entalhamento e dissecação do relevo e foi inicialmente apresentada por Smith (1950 apud França, 1968), sob a denominação razão de textura para expressar o espaçamento entre canais de drenagens em mapas topográficos com curvas de nível. Como os canais menores geralmente não são representados nestes mapas, as suas localizações podem ser identificadas pelas inflexões das curvas de nível. O autor recomendou, então, que se escolhesse a curva com maior número de inflexões e que se dividisse este número pelo perímetro $(\mathrm{P})$.

Para retratar a textura topográfica de uma região, Smith (1950 apud França, 1968) aplicou um valor médio ponderado levando em conta a área das bacias envolvidas nos cálculos individuais e propôs uma tabela de classificação de textura considerando o perímetro em milhas, mais tarde foi adaptada por França (1968) para ser expressa em km, e assim as classe de textura topográfica média passaram a ser representadas pelas seguintes faixas:

$\mathrm{Tt}<4,0-$ Grosseira

Tt 4,0-10,0 - Média

Tt $>10,0-$ Fina

Smith (1950 apud França, 1968) fez ainda um estudo das relações entre a razão de textura e a densidade de drenagem e obteve uma relação de função logarítmica entre estas duas variáveis. Adaptando este propósito, Freitas (1952 
apud Gandolfi, 1971) utilizou a seguinte expressão para o cálculo da textura topográfica:

$\log \mathrm{Tt}=0,219649+1,115 \log \mathrm{Dd}$

\section{4 - Levantamento e processamento das informações}

Devido à extensa área de abrangência da bacia do rio Capivari e à grande quantidade de informações necessárias para a efetivação da pesquisa, buscou-se uma sistemática de trabalho que possibilitasse a geração e manipulação dos dados de maneira rápida, precisa e que permitisse uma interface com outras fontes de dados. Um esquema com os principais procedimentos envolvidos na análise morfométrica das microbacias e que será detalhado nos próximos sub-capítulos está exposto na Figura 31.

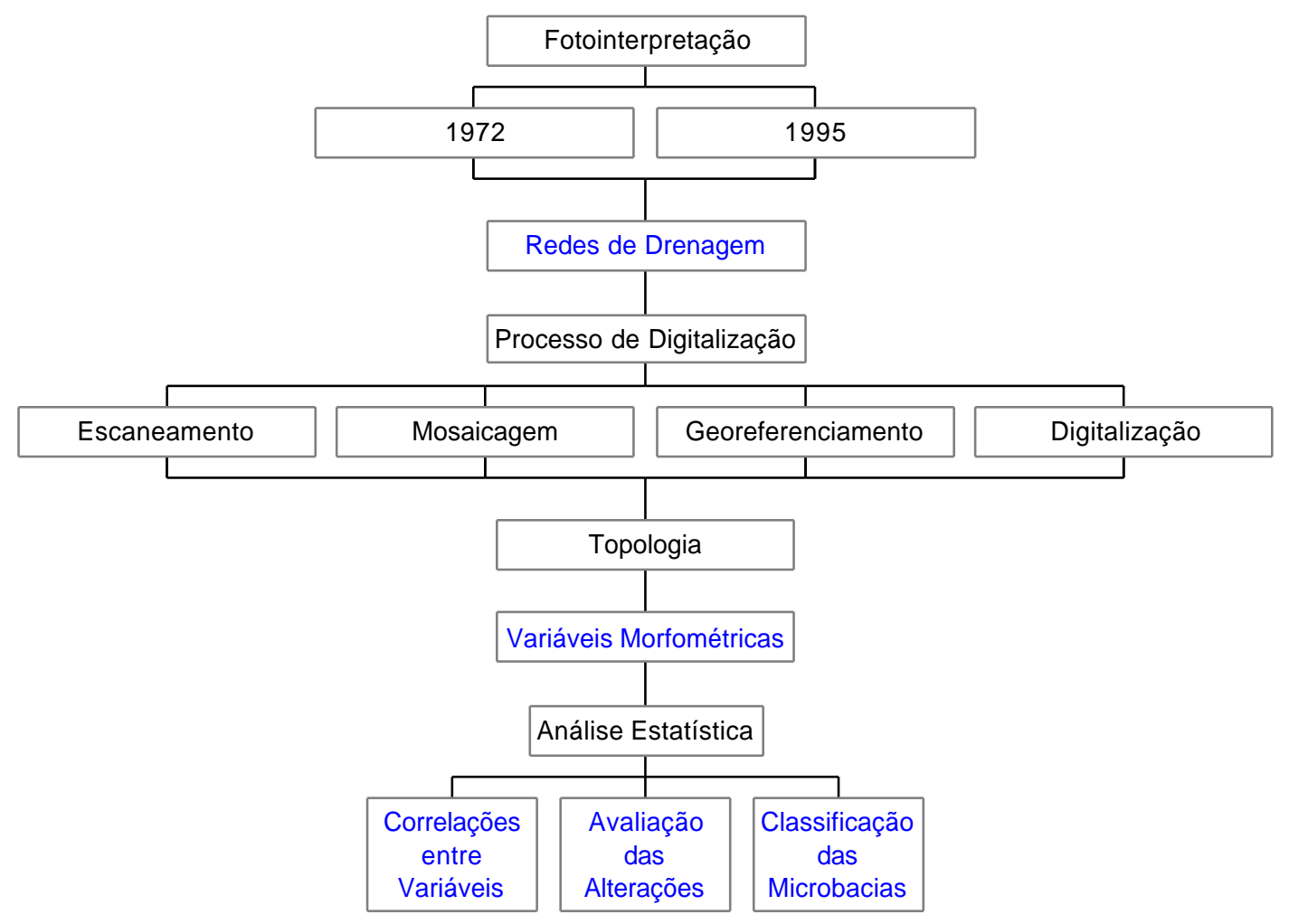

Figura 31: Esquema com a sequência dos procedimentos adotados na análise morfométrica das microbacias. 
Em relação a terminologia utilizada nesta pesquisa, utilizou-se o conceito de fotointerpretação como sendo o ato de examinar imagens fotográficas de objetos com o propósito de identificá-los e avaliar a sua significância (Colwell, 1983). A literatura especializada comumente classifica a atividade de fotointerpretação em foto-identificação, foto-análise e foto-dedução. Foto-identificação e foto-análise, conforme Rabben (1960), inclui a observação, coleta de dados, medição e identificação de aspectos visíveis nas fotografias, enquanto foto-dedução envolve processos mentais, dedutivos e/ou indutivos. Esta pesquisa envolveu fotoidentificação e foto-análise.

A digitalização e o processamento dos dados foram efetuados no programa Autocad Map $3.0^{\circledR}$. Trata-se de um aplicativo ligado à plataforma do programa Autocad $^{\circledR}$ que permite a manipulação e a interação de vários arquivos de dados ao mesmo tempo e apresenta algumas ferramentas comumente utilizadas em SIGs (Sistemas de Informações Geográficas) para obtenção de dados numéricos e topologia do terreno.

\subsection{1- Obtenção das redes de drenagem}

Para a obtenção das redes de drenagem das sessenta e quatro microbacias que compõem a bacia do rio Capivari mais a área adjacente ao rio foram analisadas cerca de quatrocentos pares estereoscópios de fotografias aéreas na escala 1:25.000, datadas de 1972/1973 e de 1994/1995. Foram utilizados estereoscópio de espelho da marca Carl Zeiss ${ }^{\circledR}$ e um estereoscópio de mesa com lentes de aumento, para observação de detalhes. Alguns aspectos considerados influentes na obtenção do traçado das redes de drenagem para a análise morfométrica estão listados na Tabela 19.

Dentre todos os aspectos apresentados, o mais influente certamente foi o fator escala. Fez-se uma tentativa para incorporar as fotografias aéreas de 1966 na análise morfométrica temporal das microbacias que não foi bem sucedida, por elas estarem na escala 1:60.000 e encobrirem alguns canais de drenagem que foram facilmente identificados nas fotografias aéreas na escala 1:25.000. 
Tabela 19: Aspectos referentes à fotointerpretação que influenciaram no traçado das redes de drenagem.

\section{Aspectos influentes na fotointerpretação}

\begin{tabular}{|c|c|}
\hline Aspectos intrínsecos & Aspectos extrínsecos \\
\hline $\begin{array}{ll}- & \text { escala } \\
\text { - } & \text { sombras } \\
\text { - } & \text { ocorrência de vegetação densa } \\
\text { - } & \text { área densamente urbanizada } \\
\text { - } & \text { presença de várzeas e áreas alagadas }\end{array}$ & $\begin{array}{l}\text { - Habilidade e experiência do intérprete } \\
\text { - } \quad \text { qualidade da cópia fotográfica } \\
\text { - } \quad \text { tipo de estereoscópio } \\
\text { - material utilizado como "overlay" }\end{array}$ \\
\hline
\end{tabular}

Tomando-se como exemplo a microbacia B51 (Figura 32 e Tabela 20), foram identificados nas fotografias aéreas de 1972 (1:25.000) 82 canais de primeira ordem, cerca de 30\% a mais que nas fotografias de 1966 (1:60.000). Entretanto, quando comparadas interpretações de fotografias aéreas de 1972 e 1995, que possuem uma mesma escala, observou-se uma diminuição no número de canais de primeira ordem, ou seja, entre 1966 e 1972 o aumento foi devido à melhor resolução espacial das fotografias de 1972 e entre 1972 e 1995, a diminuição foi devida aos processos relacionados ao manejo do terreno, como ocorreu com a grande maioria das microbacias. Este comportamento foi observado em quase todas as microbacias do rio Capivari.

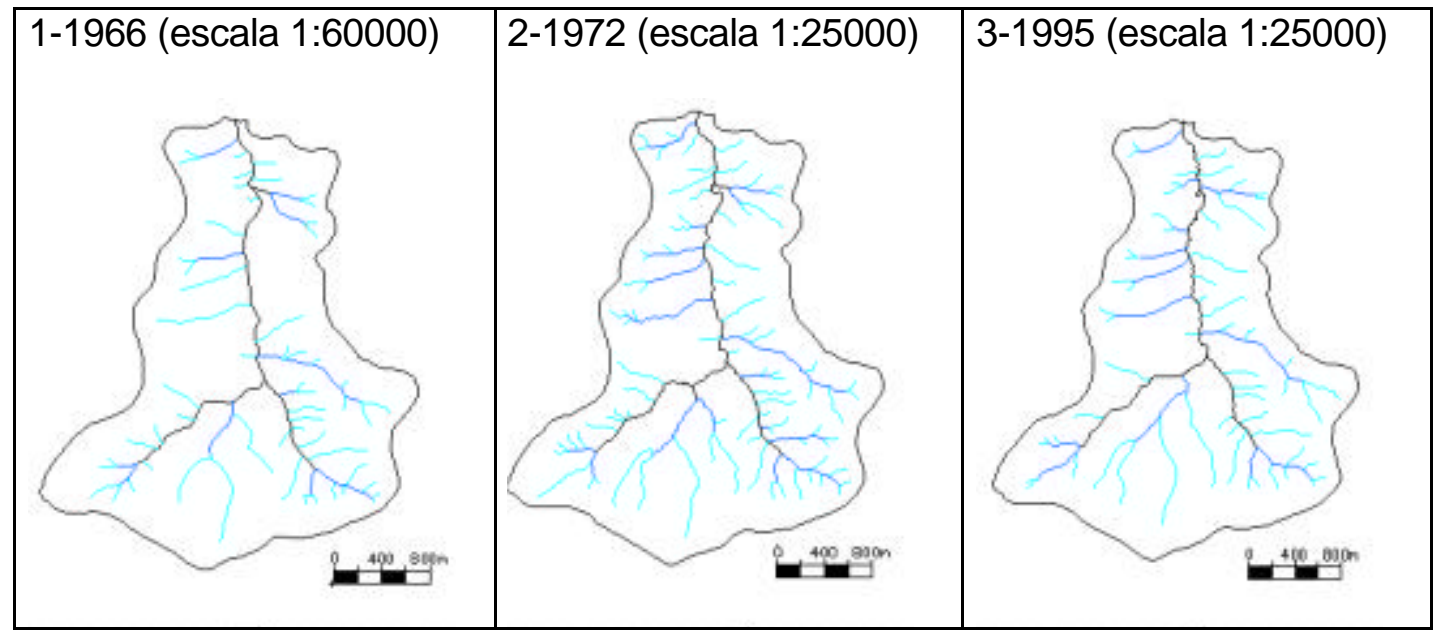

Figura 32: Redes de drenagens traçadas para a microbacia B51 com base em fotografias aéreas nas escalas 1:60.000 e 1:25.000. 
Tabela 20: Dados morfométricos da microbacia B51 adquiridos com base na interpretação das fotografias aéreas, nas escalas 1:60.000 e 1:25.000.

\begin{tabular}{l|r|r|r}
\hline & $\begin{array}{c}\text { B51 (ano 1966) } \\
\text { (escala 1:60.000) }\end{array}$ & $\begin{array}{c}\text { B51 (ano 1972) } \\
\text { (escala 1:25.000) }\end{array}$ & $\begin{array}{c}\text { B51 (ano 1995) } \\
\text { (escala 1:25.000) }\end{array}$ \\
\hline Ordem & 4 & 4 & 4 \\
\hline Área da bacia $\left(\mathrm{km}^{2}\right.$ ) & 6,49 & 6,49 & 6,49 \\
\hline Número Total de Canais & 71 & 104 & 74 \\
\hline Comprimento Total dos Canais $(\mathrm{km})$ & 21,72 & 29,58 & 25,17 \\
\hline Densidade de drenagem (km/km ${ }^{2}$ ) & 3,35 & 4,56 & 3,88 \\
\hline Densidade hidrográfica (canais/km²) & 8,63 & 12,64 & 9,09 \\
\hline Número de canais de ordem 1 & 56 & 82 & 59 \\
\hline Comprimento Total ordem 1 $(\mathrm{km})$ & 12,53 & 17,15 & 14,33 \\
\hline
\end{tabular}

Outros aspectos como as sombras que ocorrem nas vertentes opostas à incidência dos raios solares ou a presença de nuvens tendem a dificultar a visualização dos canais primários ou mesmo a trajetória dos canais de ordens superiores. Esta dificuldade é verificada também em locais onde ocorrem florestas, reflorestamentos ou capões de matas e em áreas densamente urbanizadas. Em áreas com extensas superfícies planas, como as planícies aluvionares adjacentes ao leito do rio principal, a trajetória dos canais que desaguam no rio torna-se de difícil visualização.

Dentre os aspectos extrínsecos, o mais relevante parece estar relacionado à subjetividade típica da atividade humana na identificação e qualificação das informações presentes nas fotografias aéreas, e neste âmbito contam muito a habilidade e experiência do intérprete. Outros aspectos como a qualidade da cópia fotográfica, material utilizado como "overlay" e tipo e qualidade do estereoscópio influem em menor grau de importância.

Na pesquisa utilizou-se as cópias originais das fotografias para os trabalhos em escritório, recobertas por uma película plástica do tipo utilizada como transparência manuscrita para retroprojetor. $O$ traçado das drenagens foi efetuado 
em cima desta película com o uso de canetas coloridas de ponta fina apropriadas para este tipo de material.

Quanto ao uso de estereoscópios, utilizou-se, preferencialmente, aqueles que permitem uma visão mais ampla do terreno, como é o caso dos estereoscópio de espelho, sem as lentes de detalhe. Para alguns traçados de detalhe ou em áreas de difícil percepção utilizou-se estereoscópio de mesa com lentes de aumento.

\subsection{2 - Digitalização e processamento dos dados}

A preparação das fotografias aéreas para a digitalização das redes de drenagem e processamento das informações no programa Autocad Map 3.0 ${ }^{\circledR}$ foi efetuada em três etapas: escaneamento, confecção de mosaicos e georeferenciamento.

A escolha do processo de escaneamento, em detrimento à digitalização por intermédio de uma mesa digitalizadora, que é o processo mais comumente utilizado, se deu devido à versatilidade proporcionada pelo Autocad Map 3.0 $0^{\circledR}$. O programa permite a manipulação de imagens rasterizadas (fotografias aéreas) e vetoriais (redes de drenagem) em uma mesma plataforma de trabalho, facilitando as correções e proporcionando uma digitalização mais precisa, uma vez que é feita no próprio "display", com a imagem ao fundo, e com a opção de uso de um aumento (ZOOM) apropriado.

As fotografias aéreas foram escaneadas com a rede de drenagem traçada manualmente no "overlay". No processo de escaneamento, as fotografias foram recortadas nas bordas em torno de $10 \%$ de sua área total para o descarte dos locais onde as deformações são mais acentuadas.

A confecção dos mosaicos de fotografias aéreas foi efetuada por grupos de microbacias, cada grupo constituindo um mosaico e não em um único conjunto envolvendo toda a área da bacia do rio Capivari. Este procedimento foi adotado para evitar a obtenção de arquivos de dados muito grandes, o que demandaria muita memória do equipamento de informática e diminuiria demasiadamente a 
velocidade dos processamentos. No total, foram construídos 11 mosaicos para os dados de 1972 e 11 para os dados de 1995.

Para o processo de confecção de cada mosaico a primeira atitude foi a divisão do display em duas janelas, utilizando a seguinte sequência de comandos de menu:

$$
\text { VIEW } \rightarrow \text { TILED VIEWPORTS } \rightarrow 2 \text { VIEWPORTS } \rightarrow \text { "V" }
$$

Posteriormente duas fotografias aéreas com uma faixa de superposição foram inseridas no display com a seguinte sequência de comandos de menu:

$$
\text { INSERT } \rightarrow \text { RASTER IMAGE } \rightarrow \text { "ATTACH" }
$$

Com o uso do comando ZOOM WINDOW cada uma das imagens foi ampliada em uma das janelas. Para iniciar a construção do mosaico utilizou-se a seguinte sequência de comandos de menu:

$$
\mathrm{MAP} \rightarrow \text { MAP TOOLS } \rightarrow \text { RUBBER SHEET }
$$

Com o comando RUBBER SHEET ativo escolheu-se pontos coincidentes nas duas imagens que foram utilizados como base para o processamento. Houve a preocupação de escolher pontos bem distribuídos por toda a faixa de superposição para evitar distorções. Este procedimento foi repetido até a inserção de todas as fotografias aéreas no mosaico.

Os mosaicos foram georreferenciados em coordenadas UTM, tomando-se por base a imagem de satélite da bacia que havia sido previamente georreferenciada, conforme os procedimentos descritos no Capítulo 4 e os resultados foram posteriormente avaliados com uso dos mapas topográficos, na escala 1:50.000, do IBGE.

A sequência de comandos utilizados para o georeferenciamento foi a mesma da confecção dos mosaicos, porém as duas imagens (mosaico e imagem de satélite) devem estar previamente salvas com extensão .DWG e assim foram 
abertas através do aplicativo Map utilizando a seguinte sequência de comandos de menu:

$$
\begin{gathered}
\text { MAP } \rightarrow \text { DRAWINGS } \rightarrow \text { DEFINE DRAWING SET } \rightarrow \text { "ATTACH" } \\
\text { MAP } \rightarrow \text { DRAWINGS } \rightarrow \text { ZOOM DRAWING EXTENTS } \\
\text { MAP } \rightarrow \text { DRAWINGS } \rightarrow \text { QUICK VIEW DRAWINGS } \\
\text { MAP } \rightarrow \text { QUERY } \rightarrow \text { DEFINE QUERY } \rightarrow \text { "LOCATION" } \rightarrow \text { "ALL" } \\
\text { Obs: "QUERY MODE" em DEFINE QUERY deve estar em "DRAW" }
\end{gathered}
$$

Após abertas, as imagens foram ajustadas no display com o uso do comando ZOOM, sendo cada uma delas visualizada em uma das janelas do display. Após o uso do comando RUBBER SHEET e a escolha dos pontos de controle, o mosaico georeferenciado foi salvo utilizando-se a seguinte sequência de comandos do menu:

$$
\mathrm{MAP} \rightarrow \text { SAVE BACK } \rightarrow \text { SAVE TO SOURCE DRAWINGS } \rightarrow \text { "SELEÇÃO DA IMAGEM" }
$$

Desta forma a imagem de satélite não é incorporada no mosaico, que somente adquire as suas georreferências.

Este procedimento de georreferenciamento utilizado no Autocad Map 3.0 tem o inconveniente de não apresentar valores numéricos que representem a eficiência do processo, como por exemplo o RMS error (Root Mean Square). A aceitação ou não do processamento efetuado deve ser decidida qualitativamente, com o auxílio de outros documentos já georreferenciados, como mapas topográficos da área.

Para decidir sobre a utilização ou não deste procedimento foi feito um teste efetuando-se o georreferenciamento de um dos mosaicos no programa ENVI $3.0^{\circledR}$. Obteve-se uma imagem georreferenciada com base em pontos de controle de mapas topográficos (IBGE, 1972), com RMS $=0,22$. O mesmo mosaico georreferenciado pelo Autocad Map 3.0 $0^{\circledR}$ quando comparado com este, apresentou variações insignificantes para o grau de detalhe pretendido neste trabalho. Entretanto, o tempo gasto para todo o procedimento de confecção do mosaico e georreferenciamento no Autocad Map $3.0^{\circledR}$ foi significativamente menor. 
Após todo o processo de preparação das imagens, efetuou-se a digitalização. Neste processo, foi importante efetuar a digitalização da rede de drenagem em cada microbacia isoladamente. Os canais de cada ordem foram digitalizados em "layers" distintos assim como o traçado da borda da bacia. Este procedimento teve por objetivo facilitar a criação das topologias para obtenção de dados numéricos. Um exemplo da terminologia utilizada para nomear arquivos e "layers" das microbacias é apresentado na Tabela 21.

Tabela 21: Terminologia utilizada para arquivos e "layers" na digitalização da microbacia B51.

\section{Terminologia de arquivos e "layers"}

\begin{tabular}{l|l|l}
\hline Arquivos & B51-72 (microbacia 51 em 1972) & B51-95 (microbacia 51 em 1995) \\
\hline \multirow{3}{*}{ "layers” } & $51 \mathrm{~b}-72$ (borda da bacia em 1972) & 51b-95 (borda da bacia em 1995) \\
51 or1-72 (canais de ordem 1 em 1972) & 51 or1-95 (canais de ordem 1 em 1995) \\
& 51 or2-72 (canais de ordem 2 em 1972) & 51 or2-95 (canais de ordem 2 em 1995) \\
& 51 or3-72 (canais de ordem 3 em 1972) & 51or3-95 (canais de ordem 3 em 1995) \\
& 51 or4-72 (canais de ordem 4 em 1972) & 51or4-95 (canais de ordem 4 em 1995) \\
\hline
\end{tabular}

A digitalização dos canais no próprio "display", com o uso do mouse, é facilitada pela possibilidade do uso de aumentos zOOM conforme a necessidade ou conveniência do momento, fato este que agiliza e torna o trabalho mais preciso. Para o arremate final da rede, no cruzamento entre os canais, utiliza-se o comando CLEAN UP que corta ou prolonga os canais até o cruzamento mais próximo, conforme a necessidade. A sequência de comandos de menu é a seguinte:

$$
\mathrm{MAP} \rightarrow \text { MAP TOOLS } \rightarrow \text { DRAWING CLEAN UP }
$$

A criação de topologias compreende a etapa final do processamento e são elas que permitem, não só a obtenção de dados numéricos, como também a associação de informações. Visando a obtenção dos dados necessários para a análise das redes de drenagem, utilizou-se de topologias de polígonos para a obtenção da área $(\mathrm{A})$ e do perímetro $(\mathrm{P})$ e de topologias de rede para obtenção do 
número total de canais $(\mathrm{Nt})$, do comprimento total da rede $(\mathrm{Lt})$, do número de canais por ordem de ramificação (Ni), do comprimento total por ordem de ramificação (Li) e do comprimento médio por ordem de ramificação (Lmi).

Para a criação da topologia de polígonos utilizou-se o traçado (ou "layer") da borda da microbacia e com ela obteve-se, dentre outros dados, a sua área $(A)$ e perímetro $(P)$. A sequência de comandos para este procedimento foi:

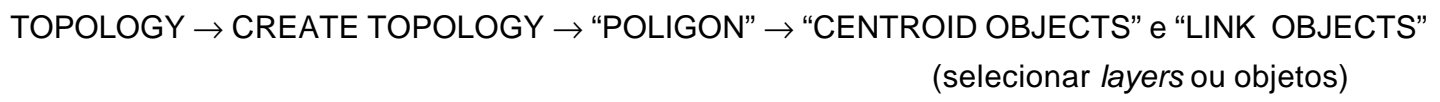

As topologias de redes foram obtidas com os traçados (ou "layers") dos níveis hierárquicos dos canais; com isto foram obtidos número total de canais (Nt), comprimento total da rede (Lt), número de canais por ordem de ramificação (Ni), comprimento total por ordem de ramificação $(\mathrm{Li})$ e comprimento médio por ordem de ramificação (Lmi). A sequência de comandos para este procedimento foi:

$$
\begin{array}{r}
\text { TOPOLOGY } \rightarrow \text { CREATE TOPOLOGY } \rightarrow \text { "NETWORK" } \rightarrow \text { "LINK OBJECTS" } \\
\text { (selecionar layers ou objetos) }
\end{array}
$$

Para a leitura dos valores referentes a estas variáveis utilizou-se a sequência de comandos:

$$
\text { TOPOLOGY } \rightarrow \text { ADMINISTRATION } \rightarrow \text { "NOME DA TOPOLOGIA" } \rightarrow \text { STATISTICS }
$$

Os valores das outras variáveis morfométricas foram obtidos em planilhas eletrônicas com base nestas variáveis primárias. Os dados, com os valores obtidos para cada variável nas 64 microbacias que compõem a bacia do rio Capivari mais a área adjacente ao rio, estão expostos no Apêndice 2.

\section{5 - Análise das alterações nas microbacias}

\subsection{1 - Análise estatística multivariada}


A estatística multivariada envolve métodos estatísticos que têm por objetivo detectar as relações em um conjunto de dados e variáveis analisando-os conjuntamente e não enfocando uma variável por vez, como ocorre na estatística univariada. Um pré-requisito para este tipo de análise, conforme Manly (1986), é que as variáveis em questão sejam consideradas de igual importância inicialmente. Neste trabalho utilizou-se a análise discriminante para determinar a significância das alterações ocorridas nas microbacias, considerando-se as redes de drenagem em 1972 e 1995 e a análise de agrupamentos, com o objetivo de agrupar as microbacias quanto ao nível de alteração nas suas redes de drenagem.

\subsubsection{1 - Análise discriminante}

A análise discriminante é utilizada em estudos estatísticos multivariados quando se pretende decidir qual, de dois ou mais possíveis grupos, um determinado indivíduo submetido a diversas mensurações deve pertencer ou, em outras palavras, indica se dois ou mais conjuntos de indivíduos, previamente agrupados, pertencem realmente a grupos distintos ou não. Além destes propósitos, conforme argumenta Davis (1986), esta análise fornece, também, a contribuição de cada variável para o distanciamento entre os grupos.

A idéia básica, segundo Landim (1997), é substituir o conjunto original das diversas mensurações de cada grupo por um único valor $D_{i}$, definido como uma combinação linear destas medidas, fornecido pela razão mínima entre a diferença entre pares de médias multivariadas e a variância multivariada dentro dos grupos. Conhecidos os $D_{i s}$, definidos como centróides dos supostos grupos, estes são comparados com um certo $D_{0}$, situado ao longo da linha expressa pela função discriminante a meio caminho entre os centróides dos grupos, e assim, cada indivíduo é comparado ao valor de $D_{0}$, com o intuito de determinar a qual dos grupos deva pertencer. Quanto maior a distância entre os centróides dos grupos, denominada distância generalizada de Mahalanobis $\left(D^{2}\right)$, melhor será a distinção entre eles.

A técnica utilizada na análise discriminante pelo programa Statistica $5.5^{\circledR}$ não prevê o cálculo de $D_{0}$, no entanto, cada indivíduo é comparado aos centróides 
dos grupos e classificado como pertencente ao grupo cuja distância do centróide seja a menor.

Os resultados obtidos na análise discriminante podem ser submetidos a testes de significância e para isto, é desejável que os dados atendam a certos pressupostos (Davis, 1986):

- as observações de cada grupo devem ser escolhidas ao acaso;

- a probabilidade de um indivíduo desconhecido pertencer a um dos grupos deve ser a mesma;

- as variáveis devem apresentar distribuição normal;

- as matrizes de variância-covariância dos grupos comparados devem ser do mesmo tamanho;

- $\quad$ todas as observações utilizadas nos cálculos devem ser classificadas sem erro.

O teste de significância utilizando o programa Statistica $5.5^{\circledR}$ pode ser efetuado seguindo os seguintes passos:

1) Determinar a hipótese nula $\left(\mathrm{H}_{0}\right)$ e a hipótese alternativa $\left(\mathrm{H}_{1}\right)$. No caso de análise discriminante, elas normalmente são enunciadas da seguinte forma:

$\mathrm{H}_{0}=$ não há discriminação entre os grupos de observações;

$\mathrm{H}_{1}=$ há discriminação entre os grupos de observações.

Desta maneira, a discriminação entre os grupos será confirmada se a $\mathrm{H}_{6}$ puder ser considerada rejeitada para um determinado grau de significância $(\alpha)$, que, segundo Weiss \& Hassett (1991), deve ser de $5 \%(\alpha=0,05)$ ou $1 \%(\alpha=0,01)$.

2) Definir os graus de liberdade para a distribuição de frequência "F".

3) Efetuar o cálculo de F. O cálculo de F é determinado pela razão entre a variância entre amostras e a variância dentre amostras (Weiss \& Hassett, 1991).

4) Comparar o valor de $F$ (calculado) com o valor de $F$ (tabelado). Caso o F calculado seja maior que o $\mathrm{F}$ tabelado, $\mathrm{H}$ deve ser rejeitada. Caso contrário, não haverá consistência para a rejeição de $\mathrm{H}_{0}$.

Outra maneira para a confirmação de hipóteses, sem o uso de tabelas, é por meio do nível $p$ ( $p$-level), fornecido quando o processamento é efetuado no 
programa Statistica $5.5^{\circledR}$. Este valor, segundo Weiss \& Hassett (1991), indica a probabilidade de aceitação do valor obtido para o teste, se a hipótese nula for verdadeira. Em outras palavras, um alto valor de $p$ não forneceria evidência para rejeitar a $\mathrm{H}_{0}$ e, em contrapartida, um baixo valor de $\mathrm{p}$ deveria oferecer fortes indícios para rejeitar $\mathrm{H}_{0}$. Entretanto, o próprio aplicativo de pesquisas rápidas (help) do programa Statistica $5.5^{\circledR}$ sugere que os valores de $\mathrm{p}$ calculados pelo programa sejam interpretados com precaução, a menos que as distâncias entre os grupos sejam grandes.

Os principais dados de saída (output) do programa Statistica $5.5^{\circledR}$ além da distância generalizada Mahalanobis e os índices do teste de significância já discutidos, são:

- A síntese das análises da função discriminante (discriminant function analysis summary) que ordena as variáveis por grau de importância na discriminação entre os grupos. Dos índices apresentados o mais significativo é o Wilks' Lambda cujos valores podem variar de 0 (perfeitamente discriminado) a 1 (não há discriminação). São dados valores de Wilks' Lambda para o modelo e também para cada variável isoladamente. $O$ valor relativo às variáveis isoladas refere-se ao valor devido para o Wilks' Lambda do modelo caso a variável em questão seja retirada dos cálculos. Assim, quanto maior for este valor, maior a importância da variável na discriminação.

- Os índices da função de classificação (classification functions), que se referem aos valores das constantes de cada variável na equação de classificação. Esta equação poderá ser utilizada quando da classificação de novos casos.

- Porcentagem e número de acertos na classificação dos casos (classification matrix).

- Distância Mahalanobis de cada caso dos centróides dos grupos (squared Mahalanobis distances from group centroids). Na listagem apresentada por esta função estão assinalados os casos que foram mal classificados.

- Probabilidade de cada caso de pertencer a cada um dos grupos (posterior probabilities). 


\subsubsection{2 - Análise de agrupamentos}

A análise de agrupamentos é definida como uma técnica classificatória utilizada quando se deseja explorar as similaridades entre variáveis, denominada modo $R$, ou entre casos, denominada modo $Q$. Davis (1986) enquadra os métodos de agrupamentos em quatro grupos: métodos de partição, métodos com origem arbitrária, métodos por similaridade mútua e métodos hierárquicos aglomerativos, sendo deste último grupo os mais utilizados em questões relacionadas ao meio físico.

Os métodos hierárquicos aglomerativos são assim chamados por agrupar sucessivamente os objetos, partindo daqueles com maior similaridade e os resultados são normalmente organizados em gráficos do tipo dendrograma. Dentre as técnicas de agrupamentos mais utilizadas destacam-se o método de ligações singulares (single linkage method), o método de agrupamento pareado proporcionalmente ponderado (unweighted pair-group method) e o método de agrupamento pareado igualmente ponderado (weighted pair-group method). Este último é o mais recomendado tanto por Davis (1986) quanto por Landim (1997).

No método de agrupamento pareado igualmente ponderado, o primeiro passo é encontrar os pares de objetos com menor coeficiente de distância (caso o critério de similaridade escolhido tenha sido este) ou com maior coeficiente de correlação. Em seguida estes pares fornecem valores médios (calculados pela média aritmética simples) que vão gerar uma nova matriz de similaridade, e assim sucessivamente, até que a matriz seja reduzida a $2 \times 2$. O critério de similaridade que usualmente agrupa melhor os dados, segundo Landim (1997), é o coeficiente de distância e a medida de distância mais comumente utilizada é a distância euclidiana.

\subsection{2 - Resultados e discussões}

Para a utilização dos dados referentes à composição das drenagens na análise estatística multivariada das alterações ocorridas nas microbacias em 
questão, foi importante uma avaliação prévia das variáveis, considerando a relação existente entre elas, a sua aplicabilidade aos métodos estatísticos e também a importância de cada uma como um indicador das alterações ambientais ocorridas no sistema. O objetivo inicial foi reduzir o número de variáveis para a análise estatística, de forma a retratar melhor as alterações.

Neste contexto, efetuou-se uma análise de correlação entre as variáveis considerando os valores absolutos obtidos para cada microbacia nas datas de 1972 e 1995. A matriz de correlação (Figura 33) mostra uma correlação acima de 90\% para dois grupos de variáveis: Nt, Lt, N1, L1, N2 e L2; e Dd, Dh, Cm, Eps e Tt. Para as variáveis Lm1, Lm2, Rb1-2 e RIm2-1 não houve correlação.

\begin{tabular}{|c|c|c|c|c|c|c|c|c|c|c|c|c|c|c|c|}
\hline & NHt & Lt & $\mathrm{Dd}$ & Dh & $\mathrm{Cm}$ & Eps & Tt & N1 & L1 & Lm1 & $\mathrm{Rb} 1-2$ & RLm2-1 & N2 & L2 & $\operatorname{Lm} 2$ \\
\hline NAt & 1.0 & 1.0 & .0 & .0 & -.1 & -.1 & .0 & 1.0 & 1.0 & -.1 & .0 & .0 & 1.0 & 1.0 & -1 \\
\hline Lt & 1.0 & 1.0 & -.1 & -.1 & -.0 & -.0 & -.1 & 1.0 & 1.0 & -.1 & .1 & .0 & 1.0 & 1.0 & -.0 \\
\hline $\mathrm{Dd}$ & .0 & -.1 & 1.0 & 1.0 & -.9 & -.9 & 1.0 & .0 & -.0 & -6 & -.2 & -.2 & 0 & -.1 & -.6 \\
\hline $\mathrm{Dh}$ & .0 & -.1 & 1.0 & 1.0 & -.8 & -.8 & 1.0 & .0 & -.0 & -.7 & -.1 & -.1 & .0 & -.0 & -.6 \\
\hline $\mathrm{Cm}$ & -.1 & -.0 & -.9 & -8 & 1.0 & 1.0 & -.9 & -.1 & -.0 & .7 & .3 & .3 & -.1 & -.0 & .8 \\
\hline Eps & -.1 & -.0 & -.9 & -8 & 1.0 & 1.0 & -.9 & -.1 & -.0 & .7 & 3 & .3 & -.1 & -.0 & .8 \\
\hline $\mathrm{Tt}$ & .0 & -.1 & 1.0 & 1.0 & -.9 & -.9 & 1.0 & .0 & -.1 & -.6 & -.2 & -.2 & .0 & -.1 & -.6 \\
\hline N1 & 1.0 & 1.0 & .0 & .0 & -.1 & -.1 & .0 & 1.0 & 1.0 & -.1 & .1 & .0 & 1.0 & 1.0 & -.1 \\
\hline $\mathrm{L} 1$ & 1.0 & 1.0 & -.0 & -.0 & -.0 & -.0 & -.1 & 1.0 & 1.0 & -.1 & .1 & .0 & 1.0 & 1.0 & -.0 \\
\hline Lm1 & -.1 & -.1 & -.6 & -.7 & .7 & .7 & -.6 & -.1 & -.1 & 1.0 & 3 & -.0 & -.2 & -.1 & .7 \\
\hline Rb1-2 & .0 & .1 & -.2 & -.1 & .3 & 3 & -.2 & .1 & .1 & .3 & 1.0 & .5 & .0 & .0 & .5 \\
\hline RLm2-1 & .0 & .0 & -.2 & -.1 & .3 & .3 & -.2 & .0 & .0 & -.0 & .5 & 1.0 & -.0 & .1 & .6 \\
\hline N2 & 1.0 & 1.0 & .0 & .0 & -.1 & -.1 & .0 & 1.0 & 1.0 & -.2 & .0 & -.0 & 1.0 & 1.0 & -.1 \\
\hline L2 & 1.0 & 1.0 & -.1 & -.0 & -.0 & -.0 & -.1 & 1.0 & 1.0 & -.1 & .0 & .1 & 1.0 & 1.0 & -.0 \\
\hline $\mathrm{Lm} 2$ & -.1 & -.0 & -6 & -.6 & .8 & .8 & -.6 & -.1 & -.0 & .7 & .5 & .6 & -.1 & -.0 & 1.0 \\
\hline
\end{tabular}

Figura 33: Matriz de correlação entre variáveis com dados das microbacias da bacia do rio Capivari das fotografias aéreas de 1972 e 1995.

Efetuou-se também a mesma análise considerando a taxa de variação de cada variável no período entre 1972 e 1995, ou seja, a porcentagem de perda (negativa) ou ganho (positiva) nas redes de drenagem de 1995 com relação às redes de drenagem de 1972. A matriz de correlação obtida (Figura 34) indica uma correlação de $100 \%$ entre as variáveis Dd, Lt, Cm, Eps e Tt e as variáveis Dh, Nt e $\mathrm{N} 1$, confirmando a interdependência existente entre elas. Desta maneira, bastaria uma variável de cada um dos dois grupos para representar as alterações ocorridas em todas as outras. 


\begin{tabular}{|c|c|c|c|c|c|c|c|c|c|c|c|c|c|c|c|}
\hline & NAt & Lt & Dd & Dh & $\mathrm{cm}$ & Eps & Tt & N1 & L1 & Lm1 & $\mathrm{Rb} 1-2$ & RLm2-1 & $\mathrm{N}_{2}$ & L2 & $\mathrm{Lm} 2$ \\
\hline Not & 1.0 & .8 & .8 & 1.0 & -.9 & -.9 & .8 & 1.0 & .5 & -.8 & -.4 & -.0 & 9 & .6 & -6 \\
\hline Lt & .8 & 1.0 & 1.0 & .8 & -1.0 & -1.0 & 1.0 & 8 & .7 & -.5 & -.3 & -.0 & .7 & .6 & -.4 \\
\hline Dd & 8 & 1.0 & 1.0 & .8 & -1.0 & -1.0 & 1.0 & .8 & .7 & -.5 & -.3 & -.0 & .7 & .6 & -.4 \\
\hline $\mathrm{Dh}$ & 1.0 & .8 & .8 & 1.0 & -.9 & -.9 & 8 & 1.0 & 6 & -.8 & -.2 & .1 & .8 & .6 & -.5 \\
\hline $\mathrm{cm}$ & -.9 & -1.0 & -1.0 & -.9 & 1.0 & 1.0 & -1.0 & -.9 & -.7 & .6 & 3 & .1 & -.8 & -6 & .5 \\
\hline Eps & -.9 & -1.0 & -1.0 & -.9 & 1.0 & 1.0 & -1.0 & -.9 & -.7 & .6 & 3 & .1 & -.8 & -.6 & .5 \\
\hline $\mathrm{Tt}$ & 8 & 1.0 & 1.0 & .8 & -1.0 & -1.0 & 1.0 & .8 & 6 & -.5 & -.3 & -.0 & .7 & .6 & -.4 \\
\hline N1 & 1.0 & .8 & .8 & 1.0 & -.9 & -.9 & 8 & 1.0 & .6 & -.8 & -.2 & .1 & 8 & .6 & -.5 \\
\hline L1 & .5 & .7 & .7 & 6 & -.7 & -.7 & 6 & 6 & 1.0 & -0 & .2 & -.3 & .3 & .2 & -.2 \\
\hline $\mathrm{Lm} 1$ & -.8 & -.5 & -.5 & -8 & .6 & .6 & -.5 & -.8 & -.0 & 1.0 & .4 & -.2 & -.7 & -.5 & 6 \\
\hline $\mathrm{Rb} 1-2$ & -.4 & -.3 & -.3 & -.2 & .3 & .3 & -.3 & -.2 & .2 & .4 & 1.0 & .3 & -.7 & -.4 & .5 \\
\hline RLIm2-1 & -.0 & -.0 & -.0 & .1 & .1 & .1 & -.0 & .1 & -.3 & -.2 & 3 & 1.0 & -.2 & .5 & .7 \\
\hline N2 & .9 & .7 & .7 & .8 & -.8 & -.8 & .7 & .8 & .3 & -.7 & -.7 & -.2 & 1.0 & .7 & -.7 \\
\hline $\mathrm{L} 2$ & .6 & .6 & 6 & 6 & -.6 & -.6 & .6 & .6 & .2 & -.5 & -.4 & .5 & .7 & 1.0 & .0 \\
\hline $\operatorname{Lm} 2$ & -.6 & -.4 & -.4 & -.5 & .5 & .5 & -.4 & -.5 & -.2 & 6 & .5 & .7 & -.7 & .0 & 1.0 \\
\hline
\end{tabular}

Figura 34: Matriz de correlação considerando a taxa de variações das variáveis das microbacias da bacia do rio Capivari no período entre 1972 e 1995.

Com base nos resultados das matrizes de correlação e também devido à grande aceitação e utilização em análises geoambientais de bacias hidrográficas, foram selecionadas inicialmente as variáveis Densidade de Drenagem (Dd) e Densidade Hidrográfica (Dh), como representantes de cada um dos grupos com altas correlações e ainda as variáveis Razão de Bifurcação entre os canais de ordem 1 e 2 (Rb1-2) e Razão de Comprimentos Médios entre os canais de ordem 2 e 1 (RLm2-1).

A Densidade de Drenagem (Dd) expressa a relação entre o comprimento total dos canais e a área da microbacia e retrata a disponibilidade de canais para o escoamento linear. A Densidade Hidrográfica (Dh) relaciona o número total de rios e a área da microbacia. As variações em Dh, como mencionado por Christofoletti (1974), refletem em alterações do comportamento hidrológico de uma bacia hidrográfica em seu aspecto mais fundamental, ou seja, o de perder ou ganhar novos cursos d'água e isto é confirmado pela correlação de $100 \%$ com N1.

Em resumo, variações significativas em Dd e Dh indicam o quanto uma bacia se alterou por perder ou ganhar novos cursos d'água e as variáveis $\mathrm{Rb} 1-2 \mathrm{e}$ RIm2-1 podem indicar alterações internas na hierarquização dos canais, mesmo não ocorrendo alterações significativas no número e no comprimento total da rede. Estas quatro variáveis são independentes entre si e os seus dados apresentam distribuição aproximadamente normal, conforme pode ser observado nos histogramas de frequência e nos testes de normalidade dispostos no Apêndice 4. 
A propósito do teste de normalidade, observa-se nos histogramas e nos testes efetuados em Dd e Dh, para datas distintas (1972 e 1995), uma ligeira mudança de comportamento (Figura 35). Estas mudanças dão uma indicação prévia de alterações ocorridas nas redes de drenagem.

Para efetuar o teste de significância das alterações utilizou-se do processo estatístico multivariado da análise discriminante considerando-se dois grupos de casos: o G 72, com as redes de drenagem das microbacias em 1972 e o G 95, com as redes de drenagem das microbacias em 1995. O objetivo foi submeter os dados ao teste de hipótese, ou seja, avaliar se as alterações foram estatisticamente significativas ou não. Para isto, considerou-se as seguintes hipóteses:

- Hipótese nula $\left(\mathrm{H}_{0}\right)$ - Não houve alteração nas microbacias da bacia do rio Capivari no período entre 1972 e 1995.

- Hipótese alternativa $\left(\mathrm{H}_{1}\right)$ - Houve alterações nas microbacias da bacia do rio Capivari no período entre 1972 e 1995.

O procedimento foi efetuado em dois passos, utilizando-se o programa Statistica $5.5^{\circledR}$ : o primeiro considerando as quatro variáveis (Dd, Dh, Rb1-2 e Rlm21), com o objetivo de identificar as variáveis mais significativas na discriminação e o segundo utilizando apenas as mais significativas para a efetivação do teste de hipótese.

Os resultados obtidos no primeiro passo estão apresentados na Tabela 22. $O$ valor $F$ obtido foi igual 2,22, para graus de liberdade 4 (numerador) e 125 (denominador) . O valor $\mathrm{F}$ tabelado da distribuição para estes graus de liberdade é de 2,37, para um grau de significância $\alpha=0,05$. Como $F$ calculado é menor que o $\mathrm{F}$ tabelado, não há consistência para rejeitar $\mathrm{H}$, considerando-se o teste que se utilizou das 4 variáveis. Observa-se, entretanto, pelos valores de Wilks' $\lambda$ que as variáveis densidade hidrográfica (Dh) e densidade de drenagem (Dd) foram as que mais contribuíram para a discriminação entre as bacias e assim foram escolhidas como as mais representativas das alterações. 


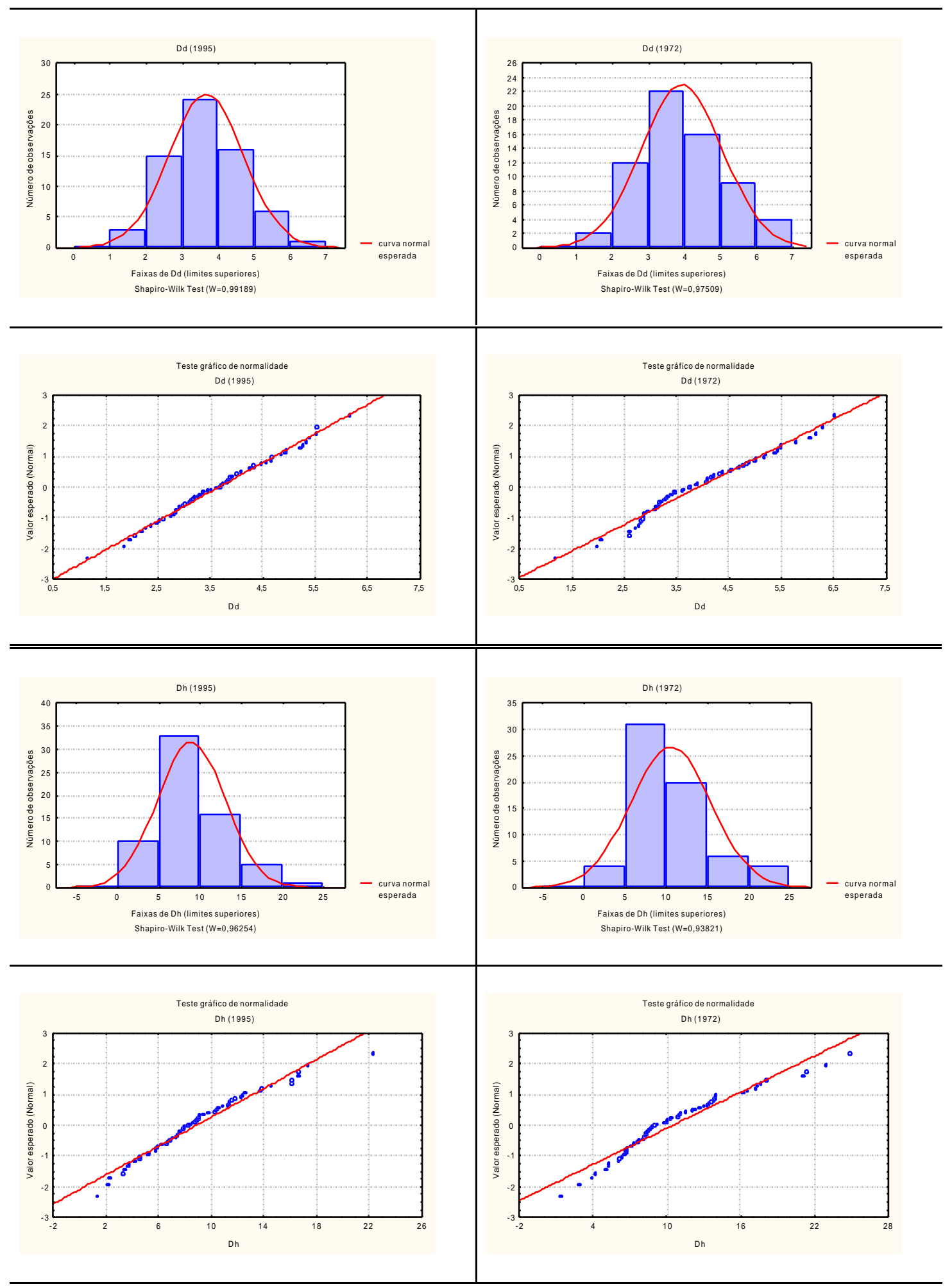

Figura 35: Histogramas de frequência e testes gráficos de normalidade para as variáveis Dd e Dh, em 1972 e 1995. 
Tabela 22: Resultados do Passo 1 da análise discriminante, considerando as variáveis Dd, Dh, Rb1-2 e RIm2-1.

\begin{tabular}{|c|c|c|c|}
\hline $\begin{array}{l}\text { Teste de significância } \\
\qquad \alpha=0,05\end{array}$ & $\begin{array}{l}\text { Porcentagem } \\
\text { de acertos }\end{array}$ & $\begin{array}{c}\text { Distância } \\
\text { Mahalanobis }\end{array}$ & $\begin{array}{c}\text { Wilks } \lambda \text { para as } \\
\text { variáveis }\end{array}$ \\
\hline $\mathrm{F}(4,145)=2,22$ (calculado) & G $72($ bacias 1972) $=55,4 \%$ & $D^{2}=0,284$ & $\mathrm{Dd}=0,953$ \\
\hline $\mathrm{F}(4,145)=2,37$ (tabelado) & G $95($ bacias 1995) $=64,3 \%$ & & $\mathrm{Dh}=0,968$ \\
\hline \multirow[t]{2}{*}{ p-level $=0,070$} & $=60,0 \%$ & $\begin{array}{c}\text { Wilks } \lambda \text { para o } \\
\text { modelo }\end{array}$ & $\mathrm{Rb}_{1-2}=0,939$ \\
\hline & & Wilks $\lambda=0,934$ & $R_{\mathrm{Lm} 2-1}=0,940$ \\
\hline
\end{tabular}

Os resultados obtidos no passo 2, utilizando as variáveis Dd e Dh (Tabela 23) indicam um valor $F$ igual 3,90 para graus de liberdade 2 (numerador) e 127 (denominador) . O valor $\mathrm{F}$ tabelado da distribuição para estes graus de liberdade é de 3,00, para um grau de significância $\alpha=0,05$. Como $F$ calculado é maior que o $F$ tabelado, há consistência para rejeitar $\mathrm{H}_{0}$, ou seja, pode-se afirmar que houve alterações estatisticamente significativas nas microbacias no período considerado. Este fato pode ainda ser comprovado pelo baixo valor obtido para $p$-level $=0,023$.

Tabela 23: Resultados do Passo 2 da análise discriminante, considerando as variáveis Dd e Dh.

\begin{tabular}{|c|c|c|c|}
\hline $\begin{array}{l}\text { Teste de significância } \\
\qquad \alpha=0,05\end{array}$ & $\begin{array}{l}\text { Porcentagem } \\
\text { de acertos }\end{array}$ & $\begin{array}{c}\text { Distância } \\
\text { Mahalanobis }\end{array}$ & $\begin{array}{c}\text { Wilks } \lambda \text { para as } \\
\text { variáveis }\end{array}$ \\
\hline $\mathrm{F}(4,145)=3,90$ (calculado) & G72 (bacias 1972) $=50,8 \%$ & \multirow[t]{2}{*}{$\vec{D}^{2}=0,245$} & $\mathrm{Dd}=0,968$ \\
\hline$F(4,145)=3,00$ (tabelado) & G95 $($ bacias 1995$)=64,6 \%$ & & \multirow{3}{*}{$\mathrm{Dh}=0,986$} \\
\hline \multirow[t]{2}{*}{ p-level $=0,023$} & \multirow[t]{2}{*}{ Total } & $\begin{array}{c}\text { Wilks } \lambda \text { para o } \\
\text { modelo }\end{array}$ & \\
\hline & & Wilks $\lambda=0,942$ & \\
\hline
\end{tabular}

Considerando a maior influência de Dh e Dd na discriminação entre as bacias e as suas importâncias como indicadores de alterações no número e comprimento dos canais, efetuou-se uma análise de agrupamento considerando as taxas de variações (em porcentagem) destas variáveis no período entre 1972 a 1995, com o objetivo de agrupar as bacias por grau de alteração na rede de drenagem. 
Foi utilizado o método hierárquico aglomerativo e a técnica de agrupamento pareado igualmente ponderado (weighted pair-group method), considerando o coeficiente de distância e a medida de distância euclidiana como critério de similaridade. Pelo dendrograma obtido (Figura 36), tomando-se como limite o valor de distância igual a 10, pode-se observar no lado direito e no centro dois grandes grupos e no lado direito três grupos menores que foram, posteriormente, agrupados em um só, uma vez que distinguem dos outros dois por apresentarem maiores taxas de alterações.

análise de agrupamento (65 casos)

agrupamento pareado igualmente ponderado

distâncias euclidianas

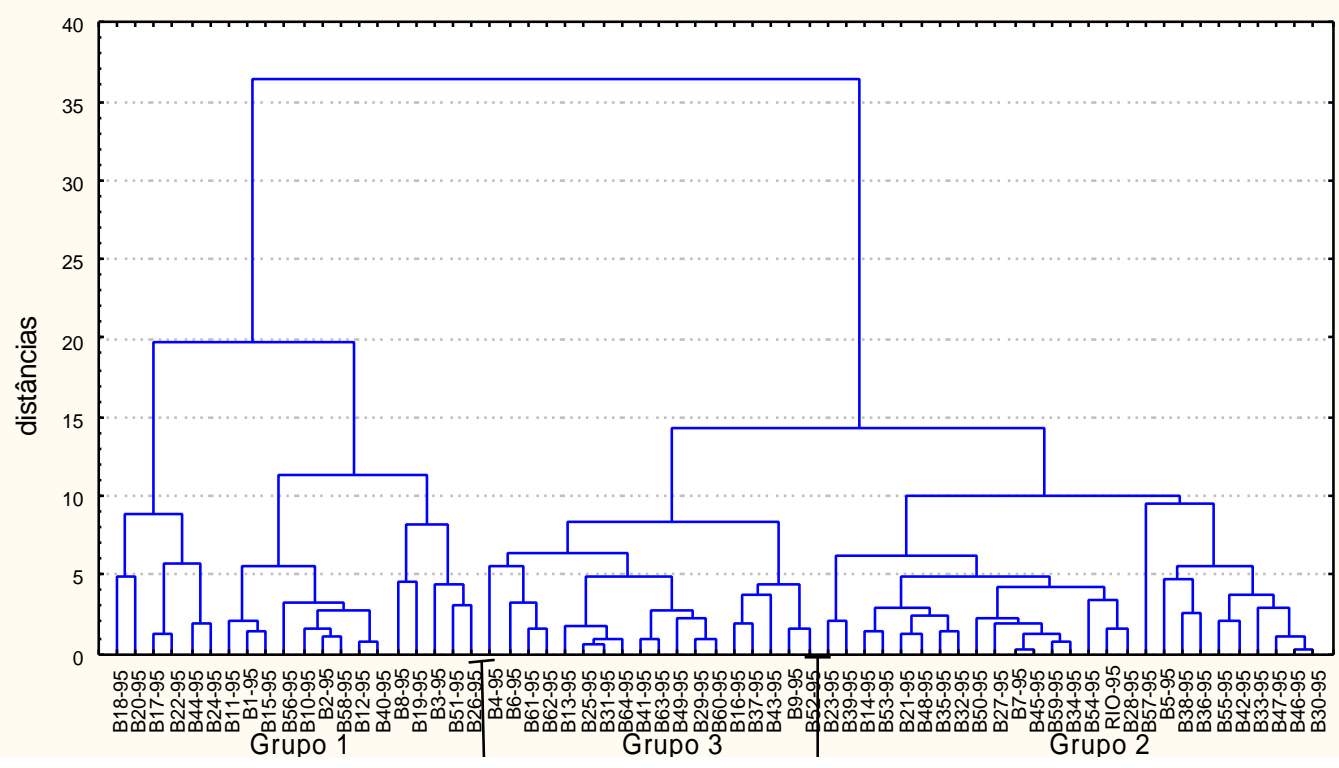

Figura 36: Dendrograma obtido para as 65 microbacias da bacia do rio Capivari considerando a taxa de variação das variáveis Dr e Dh entre 1972 e 1995.

Para analisar e determinar uma terminologia aos grupos definidos pela análise de agrupamento, efetuou-se novamente a análise discriminante, desta vez considerando os casos classificados por grupos (Tabela 24). Os principais resultados obtidos estão apresentados na Tabela 25.

Observa-se uma discriminação altamente significativa para o grupo 1, onde $F(2,37)=5,07$ e o p-level=0,011, sendo, então, classificado como de alterações significativas. Para os outros grupos, o teste de significância não confirma 
alterações significativas entre 1972 e 1995, entretanto, pode-se observar por meio, de $D^{2}$ e da porcentagem de acertos, que o grupo 2 está melhor discriminado que o grupo 3. Desta forma, o Grupo 2 foi então denominado como de alterações mediamente significativas e o Grupo 3 como de alterações pouco significativas. $\mathrm{O}$ mapa com o resultado da classificação é apresentado na Figura 37.

Tabela 24: Classificação das microbacias por grau de alteração com base nos grupos obtidos com a análise de agrupamento.

\begin{tabular}{c|l}
\hline Grupo & \multicolumn{1}{|c}{ Relação de microbacias } \\
\hline Grupo 1 & $\begin{array}{l}\text { B26, B24, B40, B44, B56, B58, B51, B22, B20, B18, B19, B17, B15, B12, } \\
\text { B10, B8, B11, B3, B2, B1 }\end{array}$ \\
\hline Grupo 2 & $\begin{array}{l}\text { B28, B30, B32, B34, B36, B38, B42, B46, B48, B50, B54, B59, B57, B55, } \\
\text { B53, B47, B45, B39, B35, B33, B31, B23, B21, B14, B7, B5, Rio }\end{array}$ \\
\hline Grupo 3 & $\begin{array}{l}\text { B52, B60, B62, B64, B63, B61, B49, B43, B41, B37, B31, B29, B16, B25, } \\
\text { B13, B9, B6, B4 }\end{array}$ \\
\hline
\end{tabular}

Tabela 25: Resultados da análise discriminante obtidos no programa Statística $5.5^{\circledR}$ para grupos definidos na análise de agrupamento.

\begin{tabular}{|c|c|c|c|}
\hline & Grupo 1 & Grupo 2 & Grupo 3 \\
\hline $\begin{array}{c}\text { teste de } \\
\text { significância } \\
\alpha=0,05\end{array}$ & $\begin{array}{l}F(2,37)=5,07 \text { (calc.) } \\
F(2,37)=3,25 \text { (tab.) } \\
\text { p-level }=0,011\end{array}$ & $\begin{array}{l}\mathrm{F}(2,51)=1,52 \text { (calc.) } \\
\mathrm{F}(2,51)=3,20 \text { (tab.) } \\
\mathrm{p}-\text { level }=0,227\end{array}$ & $\begin{array}{l}F(2,33)=0,30 \text { (calc.) } \\
F(2,39)=3,30 \text { (tab.) } \\
\text { p-level }=0,743\end{array}$ \\
\hline $\begin{array}{c}\text { Porcentagem } \\
\text { de acertos }\end{array}$ & $\begin{array}{l}\text { G72 }=50,0 \% \\
\text { G95 }=75,0 \% \\
\text { Total }=62,5 \%\end{array}$ & $\begin{array}{l}\text { G1 }=55,5 \% \\
\text { G2 }=66,6 \% \\
\text { Total }=61,1 \%\end{array}$ & $\begin{array}{ll}\mathrm{G} 1(\mathrm{~B} 1972) & =50,0 \% \\
\mathrm{G} 2(\mathrm{~B} 1995) & =66,6 \% \\
\text { Total } & =58,3 \%\end{array}$ \\
\hline $\begin{array}{c}\text { distância } \\
\text { mahalanobis }\end{array}$ & $D^{2}=1,096$ & $\mathrm{D}^{2}=0,239$ & $\mathrm{D}^{2}=0,073$ \\
\hline
\end{tabular}




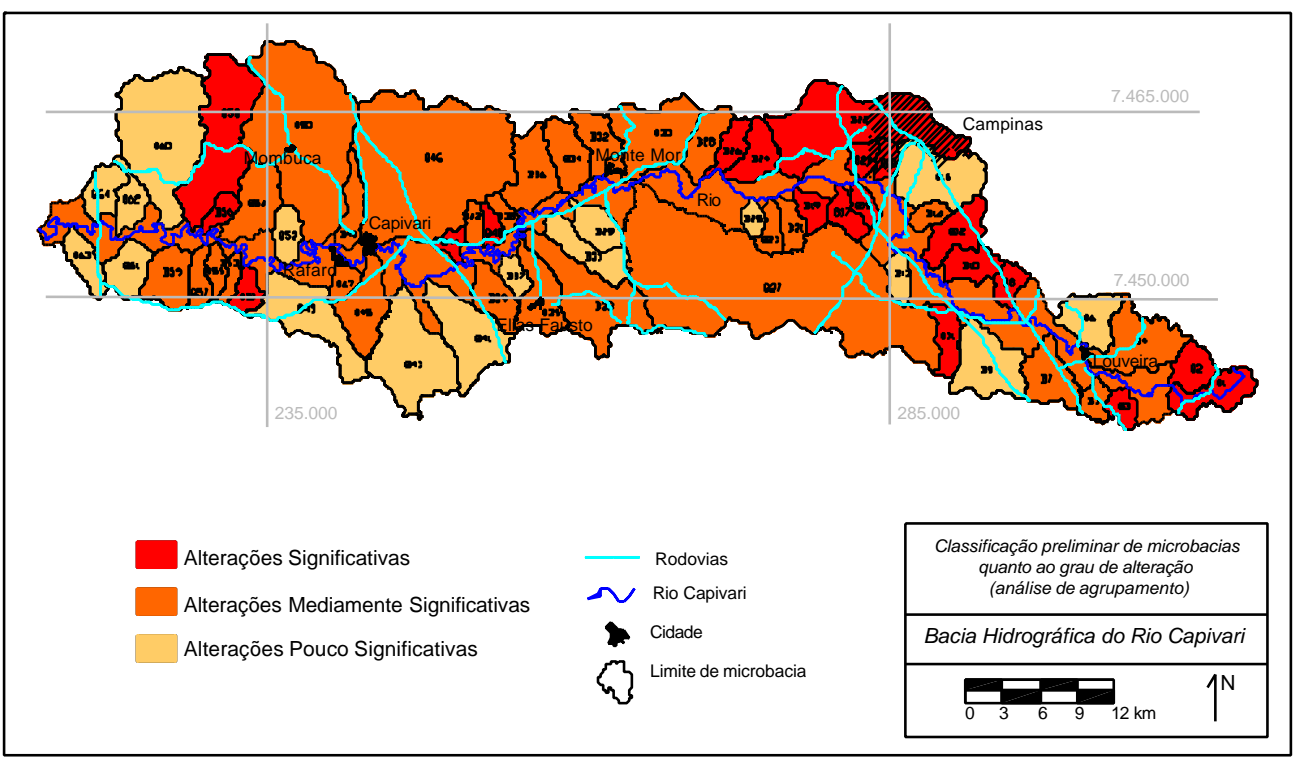

Figura 37: Mapa com a classificação das microbacias quanto ao grau de alteração entre 1972 e 1995 (análise de agrupamento).

\section{6 - Conclusões parciais}

\subsection{1 - Quanto à obtenção e processamento da rede de drenagem}

A obtenção da rede de drenagem por meio da interpretação de fotografias aéreas, apesar de constituir um método trabalhoso, ainda faz-se necessária. $O$ processo informatizado, por meio do processamento das imagens de satélite comumente disponíveis no Brasil (Spot e Landsat), não permite a identificação de grande parte dos canais de primeira ordem, devido à baixa resolução espacial destas imagens. Esta deficiência deverá ser suprida em um futuro próximo, com o lançamento de novos satélites comerciais que permitirão a obtenção de imagens com melhor resolução espacial a preços acessíveis.

Fotografias aéreas em escala pequena, assim como as imagens de satélite, também dificultam a identificação dos canais de menor nível hierárquico. A experiência de inserir o conjunto de fotografias aéreas, na escala 1:60.000, de 1966, nas análises efetuadas nesta pesquisa, não foi bem sucedida por 
apresentar resultados não compatíveis com aqueles obtidos para as fotografias aéreas, na escala 1:25.000.

O processo de digitalização utilizado, optando-se pelo escaneamento das fotografias aéreas em detrimento do método mais comum, que é de digitalização por meio de mesa digitalizadora, mostrou-se adequado, considerando-se a grande quantidade de fotografias aéreas. Esse processo mostrou-se mais versátil na efetivação dos mosaicos e na digitalização da rede de drenagem, facilitando os ajustes quando necessários. A disponibilidade da fotografia aérea no "display" permitindo, assim, o uso de aumentos (ZOOM), dão maior precisão na digitalização da rede.

A construção dos mosaicos e o georreferenciamento efetuado com o uso do programa Autocad Map 3.0 ${ }^{\circledR}$, apesar do inconveniente de não apresentar valores numéricos que representem a eficiência do processo (RMS error), não apresentou variações significativas quando comparado com o processo efetuado em um programa específico para o processamento de imagens.

\subsection{2 - Quanto à análise morfométrica}

A máxima correlação apresentada pelas variáveis $\mathrm{Dd}$, Lt, $\mathrm{Cm}$, Eps e Tt, e pelas variáveis $\mathrm{Dh}, \mathrm{Nt}$ e N1, quando utilizadas as taxas de variações temporais, era esperada, considerando-se a interdependência existente entre elas. Desta forma, bastaria eleger uma variável de cada um destes dois grupos como representativa das alterações temporais nas microbacias neste âmbito. As variáveis Dd e Dh foram as escolhidas para serem utilizadas na análise estatística multivariada das alterações ocorridas nas microbacias, por se constituírem em parâmetros amplamente difundidos e aceitos como significativos em análises geoambientais de bacias hidrográficas.

Com base nas variáveis Densidade de drenagem (Dd) e Densidade Hidrográfica (Dh) e utilizando-se da análise estatística discriminante pode-se afirmar que houve alterações significativas na composição das redes de drenagem das microbacias da bacia do rio Capivari no período entre 1972 e 1995. 
As microbacias foram classificadas quanto ao nível de alteração na composição da rede de drenagem, com base nas taxas de variações das variáveis Dh e Dd. Para isto, utilizou-se análise de agrupamento e análise discriminante novamente; a primeira para separar grupos e a segunda para determinar o significado de cada grupo. Desta forma, como resultado, as microbacias foram agrupadas em três grupos (classes): alterações significativas, alterações mediamente significativas e alterações pouco significativas. 


\section{6 - AVALIAÇÕES DOS PARÂMETROS MORFOMÉTRICOS E DAS MICROBACIAS}

\section{1 - Considerações iniciais}

Neste capítulo apresenta-se uma análise pormenorizada dos dados obtidos no levantamento morfométrico das 64 microbacias da bacia do rio Capivari, com base nas fotografias aéreas de 1972 e 1995. O intuito é o de avaliar as relações existentes entre as variáveis morfométricas e as características do meio físico e também a influência das atividades antrópicas nas alterações temporais ocorridas nas variáveis. Para tanto, foram utilizados estudos estatísticos básicos e análises gráficas das relações entre variáveis, com o suporte do programa Statistica $5.5^{\circledR}$.

Para a efetivação deste estudo foram utilizados procedimentos que culminaram com a identificação e descrição das microbacias onde as alterações foram mais pronunciadas. A sequência de procedimentos utilizados foi:

- compreensão das características morfométricas originais das microbacias, ou seja, no período inicial da avaliação, em 1972. Para isto foram efetuadas classificações para as microbacias, com base em cada uma das variáveis morfométricas. Posteriormente, foram identificadas as microbacias cujos índices morfométricos mais se afastaram da média;

- avaliação de possíveis inter-relações existentes entre variáveis morfológicas, variáveis da rede de drenagem e entre variáveis morfológicas e da rede de drenagem;

- avaliação da influência do substrato rochoso nas variáveis morfológicas e da rede de drenagem obtidas para as microbacias no período inicial (1972);

- avaliação das alterações temporais nas variáveis da rede de drenagem, com base nos levantamentos de 1972 e 1995;

- avaliação da influência dos dados morfométricos originais, ou seja, aqueles obtidos para as microbacias no levantamento de 1972, nas alterações temporais verificadas; 
- avaliação da influência de características de uso e ocupação nas alterações temporais verificadas;

- identificação das microbacias onde as alterações foram mais pronunciadas e as possíveis causas destas alterações.

\section{2 - Definição de faixas de distribuição para as variáveis morfométricas}

Como um primeiro passo para a análise da influência das variáveis morfométricas na avaliação das alterações ocorridas nas microbacias, procurou-se identificar as microbacias que, para cada variável, apresentaram valores extremados ou, em outras palavras, os valores mais destoantes da média. Para isto determinou-se faixas de distribuição (valores altos, médios e baixos) para cada variável morfométrica, considerando-se os dados das 64 microbacias que compõem a bacia do rio Capivari no início do processo de avaliação, ou seja, no levantamento morfométrico de 1972.

O objetivo deste procedimento foi analisar se os valores extremados, encontrados nas faixas de valores altos ou baixos, estão contribuindo para acelerar ou desacelerar as alterações verificadas nas microbacias. Vale ressaltar, entretanto, que não é escopo deste trabalho propor sistemas de classificações de variáveis morfométricas para serem utilizadas como parâmetros em outras bacias, mas somente qualificar os dados numéricos obtidos na bacia do rio Capivari para facilitar a análise coletiva e/ou individual das microbacias.

Para a delimitação das faixas de distribuição utilizou-se procedimentos estatísticos básicos sendo que os limites foram definidos utilizando-se o método dos percentis (Weiss \& Hassett, 1991), que divide o conjunto de dados em dez partes iguais, sendo a mediana o limite correspondente à $50 \%$ dos dados. Como o interesse desta análise foi destacar apenas os valores mais extremados, utilizou-se como limites entre faixas de distribuição os percentis $10 \%$ e $90 \%$, sendo o percentil $10 \%$ o valor limitante entre as faixas de valores baixos e valores médios, e o percentil $90 \%$ o valor limitante entre as faixas de valores médios e de valores altos. 


\subsection{1 - Índice de circularidade (Ic)}

O conjunto de valores referentes aos índices de circularidade das 64 microbacias constituem uma distribuição normal. Os dados estatísticos básicos mostram um valor médio e mediana de 0,54 para um desvio padrão de 0,11 (Tabela 26).

Tabela 26: Dados estatísticos básicos e faixas de distribuição para os valores de lc.

\begin{tabular}{|c|c|c|c|c|c|c|c|c|}
\hline $\begin{array}{l}\text { BASIC } \\
\text { STATS }\end{array}$ & $\begin{array}{c}\text { número } \\
\text { de casos }\end{array}$ & média & mediana & $\begin{array}{c}\text { valor } \\
\text { mínimo }\end{array}$ & $\begin{array}{l}\text { valor } \\
\text { máximo }\end{array}$ & $\begin{array}{l}\text { desvio } \\
\text { padrão }\end{array}$ & $\begin{array}{c}\text { v. limite } \\
10 \%\end{array}$ & \begin{tabular}{|c|} 
v. $\operatorname{limite}_{90 \%}$ \\
\end{tabular} \\
\hline Ic & 64 & 54 & 54 & 33 & 77 & 11 & 36 & 69 \\
\hline & \multirow{2}{*}{\multicolumn{3}{|c|}{$\begin{array}{c}\text { VALORES ALTOS } \\
>0,69\end{array}$}} & \multirow{2}{*}{\multicolumn{3}{|c|}{$\begin{array}{c}\text { VALORES MÉDIOS } \\
0,36-0,69\end{array}$}} & \multirow{2}{*}{\multicolumn{2}{|c|}{$\begin{array}{l}\text { ALORES BAIXOS } \\
\quad<0,36\end{array}$}} \\
\hline Ic & & & & & & & & \\
\hline
\end{tabular}

A Figura 38 mostra os valores de lc obtidos para cada microbacia. Nota-se que nenhuma das 64 microbacias da bacia do rio Capivari apresenta lc muito próximo da unidade, predominando, assim, as formas alongadas. As microbacias que apresentam os maiores valores (entre 0,7 e 0,8) são B20, B25, B47, B52 e B61 e as bacias mais alongadas são B27, B33, B48 e B58.

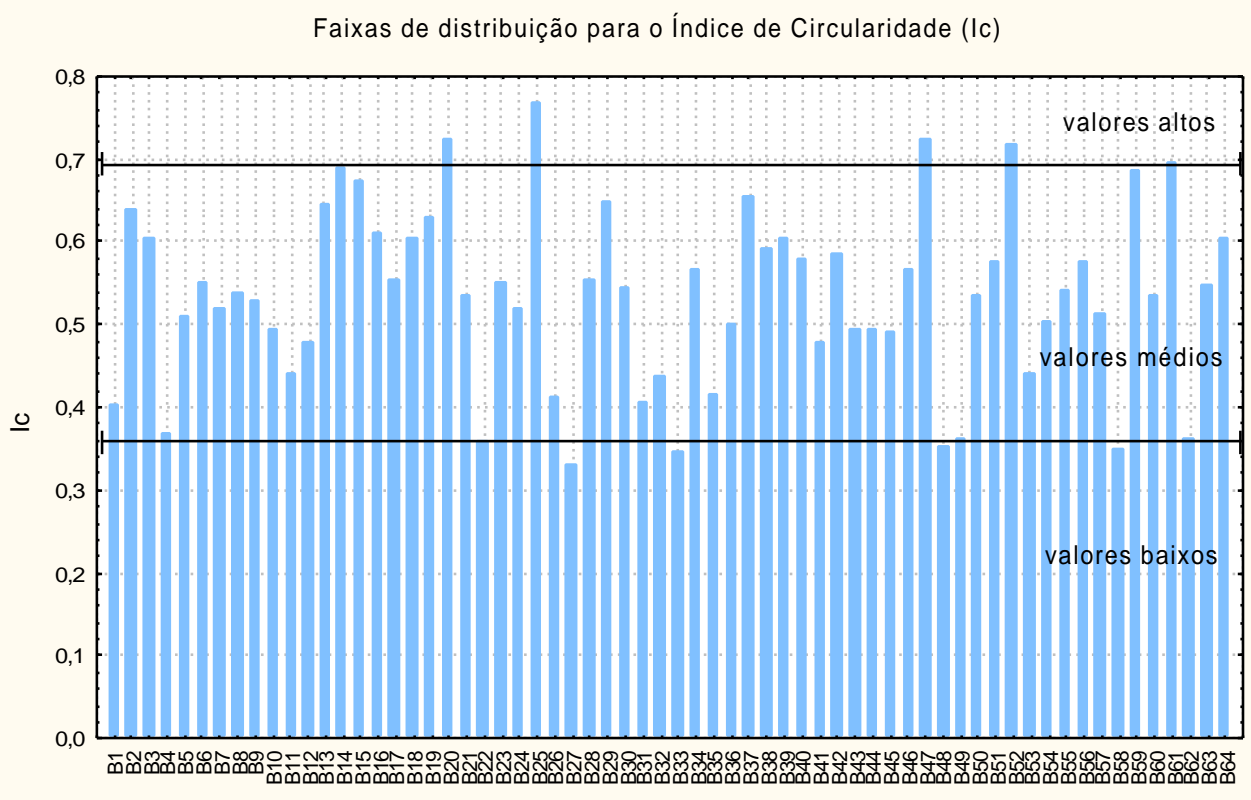

Figura 38: Valores da variável índice de circularidade (Ic) das microbacias da bacia do rio Capivari. 


\subsection{2 - Relação de relevo (Rr)}

As microbacias da bacia do rio Capivari apresentam relação de relevo com valor médio de 22,8 $\mathrm{m} / \mathrm{km}$ e desvio padrão de 8,1 (Tabela 27). Observa-se uma alta dispersão considerando o conjunto total de dados, e também entre os limites correspondentes a $10 \%$ e $90 \%$ dos casos.

Tabela 27: Dados estatísticos básicos e faixas de distribuição para $\mathrm{Rr}$.

\begin{tabular}{l|r|r|r|r|r|r|r|r|}
$\begin{array}{l}\text { BASIC } \\
\text { STATS }\end{array}$ & $\begin{array}{c}\text { número } \\
\text { de casos }\end{array}$ & média & mediana & $\begin{array}{c}\text { valor } \\
\text { mínimo }\end{array}$ & $\begin{array}{c}\text { valor } \\
\text { máximo }\end{array}$ & $\begin{array}{c}\text { desvio } \\
\text { padrão }\end{array}$ & $\begin{array}{c}\text { v. limite } \\
10 \%\end{array}$ & $\begin{array}{c}\text { v. limite } \\
90 \%\end{array}$ \\
\hline Rr & 64 & 22,8 & 22,5 & 8,7 & 53,4 & 8,1 & 13,3 & 33,0 \\
\hline
\end{tabular}

Dentre as seis microbacias com as maiores relações de relevo (B2, B6, B10, B11, B14 e B51), cinco apresentam valores entre 33 e 40 m/km (Figura 39). A exceção é a microbacia B6 que apresenta índice superior a $50 \mathrm{~m} / \mathrm{km}$. Estas microbacias situam-se, predominantemente, próximas à região de cabeceira do rio Capivari. As microbacias com os mais baixos valores de relação de relevo são: B27, B28, B33, B43, B46 e B50.

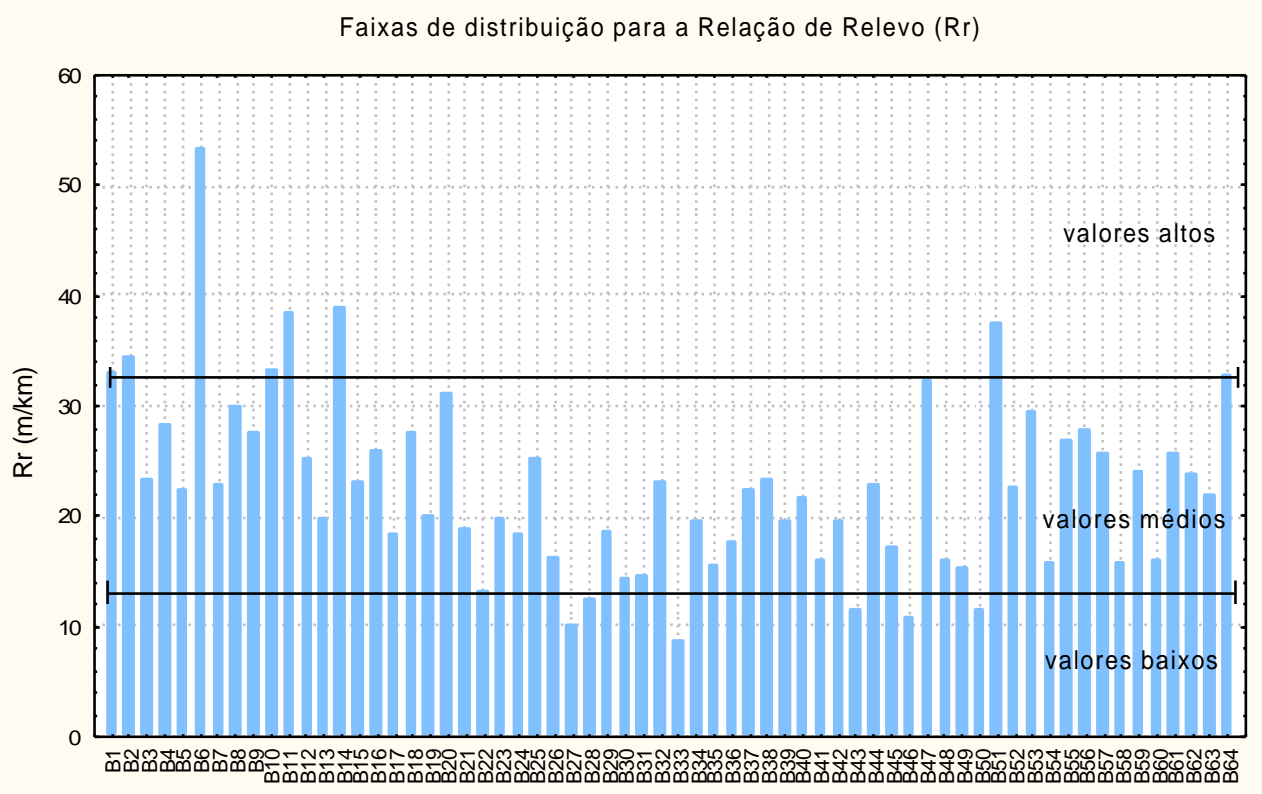

Figura 39: Valores da variável relação de relevo $(\mathrm{Rr})$ das microbacias da bacia do rio Capivari. 


\subsection{3 - Índice de sinuosidade (Si)}

Nos canais principais das microbacias da bacia do rio Capivari, predominantemente, não existem sinuosidade elevada, apresentam um valor médio de 2,28 e o intervalo entre os valores limites correspondentes a 10\% e 90\% dos casos é de 0,37 (Tabela 28).

Tabela 28: Dados estatísticos básicos e faixas de distribuição para os valores de Si.

\begin{tabular}{l|r|r|r|r|r|r|r|r|}
$\begin{array}{l}\text { BASIC } \\
\text { STATS }\end{array}$ & $\begin{array}{c}\text { número } \\
\text { de casos }\end{array}$ & média & mediana & $\begin{array}{c}\text { valor } \\
\text { mínimo }\end{array}$ & $\begin{array}{c}\text { valor } \\
\text { máximo }\end{array}$ & $\begin{array}{c}\text { desvio } \\
\text { padrão }\end{array}$ & $\begin{array}{c}\text { v. } 1 \text { limite } \\
10 \%\end{array}$ & $\begin{array}{c}\text { v. limite } \\
90 \%\end{array}$ \\
\hline Si & 64 & 1,28 & 1,22 & 1,08 & 1,97 & .18 & 1.11 & 1,48 \\
\hline
\end{tabular}

Mais de $50 \%$ dos casos apresentam sinuosidade inferior a 1,2 e apenas as microbacias B1, B22, B34, B50, B54 e B60 apresentam valores superiores a 1,5 (Figura 40). O canal da microbacia B1, que apresenta o mais alto índice de sinuosidade dentre todas as microbacias, corresponde, na realidade, ao próprio leito do rio Capivari, em sua região de cabeceira.

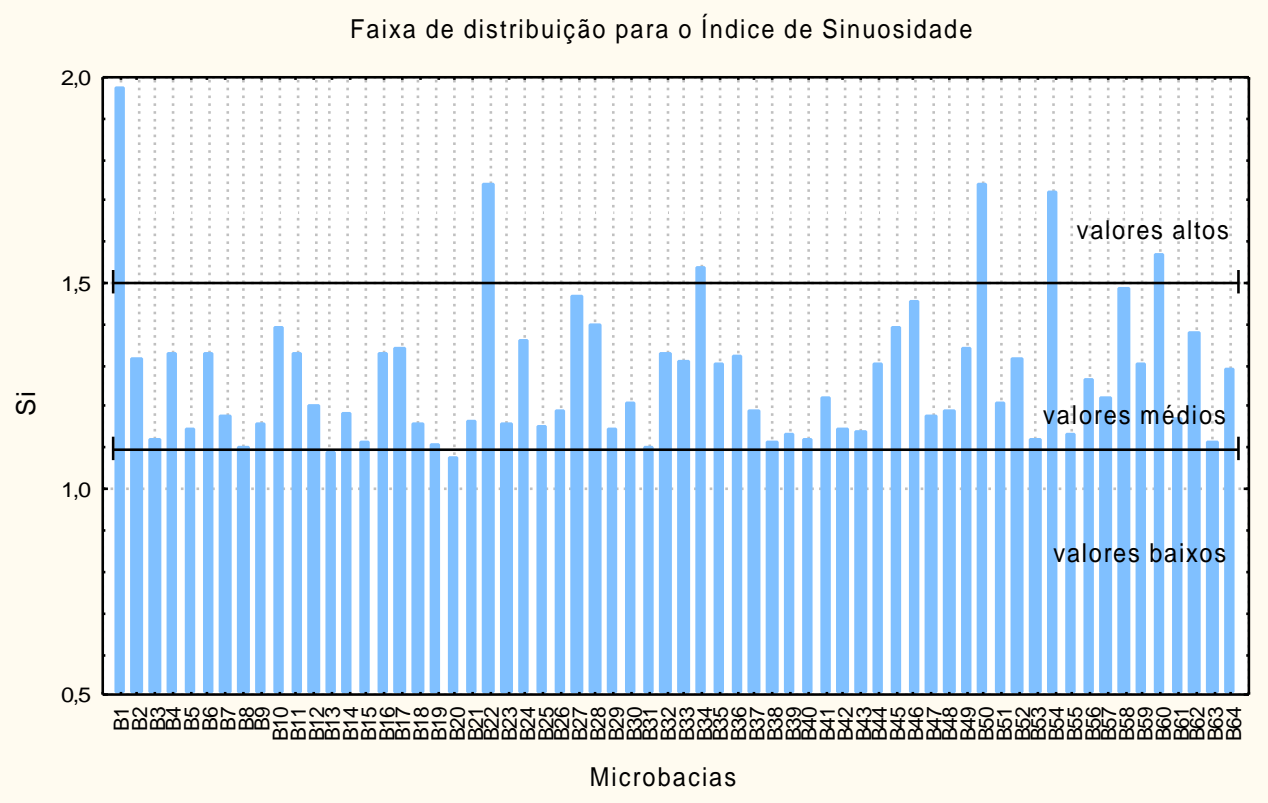

Figura 40: Valores da variável índice de sinuosidade (Si) das microbacias da bacia do rio Capivari. 


\subsection{4 - Densidade de drenagem (Dd)}

O conjunto de valores referentes à densidade de drenagem das microbacias constituem uma distribuição normal, com média e mediana de 3,8 $\mathrm{km} / \mathrm{km}^{2}$ e desvio padrão de 1,1. O intervalo entre os valores limites correspondentes a $10 \%$ e $90 \%$ dos casos é de 2,7 (Tabela 29).

Tabela 29: Dados estatísticos básicos e faixas de distribuição para Dd.

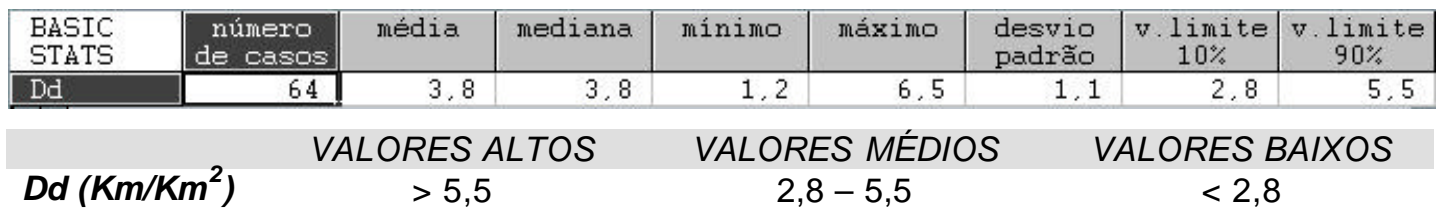

As microbacias que apresentam altos valores de densidade de drenagem são B2, B4, B10, B56 e B59 e aquelas que apresentam os mais baixos valores são B15, B19, B24, B33, B31 e B41 (Figura 41).

Faixas de distribuição para a Densidade de Drenagem (Dd)

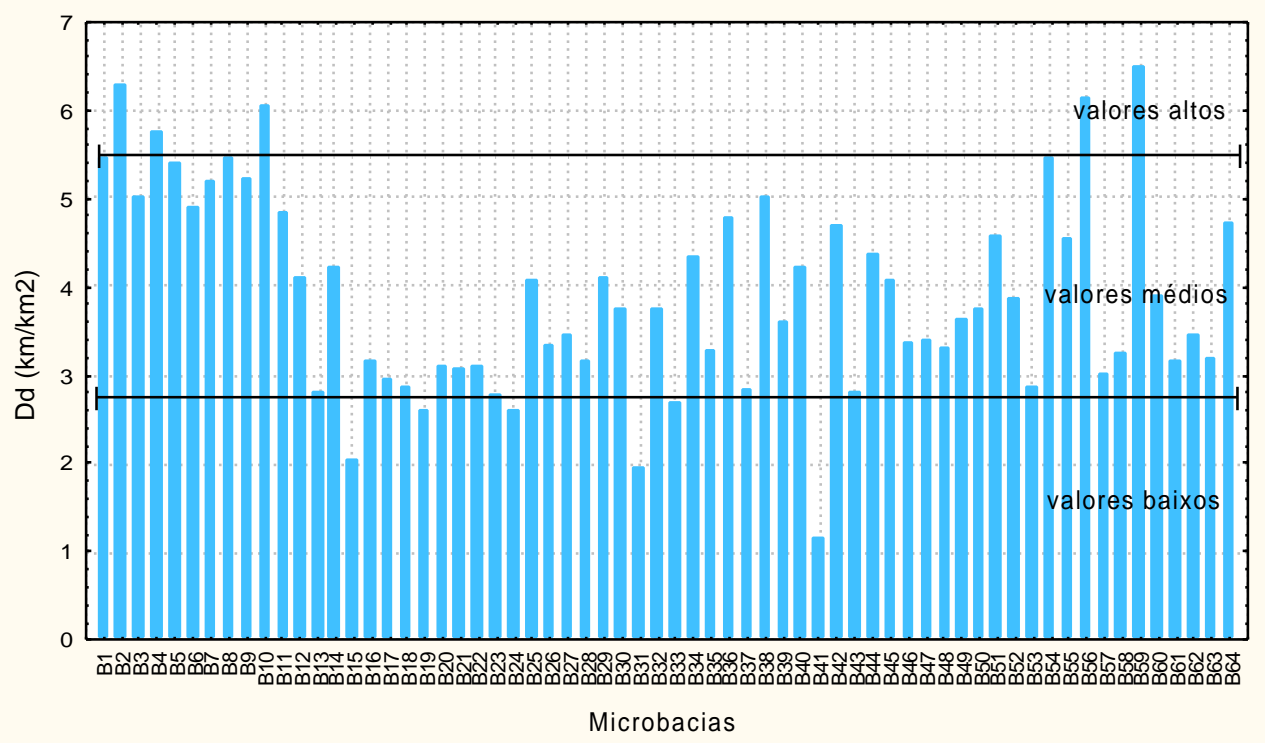

Figura 41: Valores da variável densidade de drenagem (Dd) das microbacias da bacia do rio Capivari. 


\subsection{5 - Densidade hidrográfica (Dh)}

O valor médio da densidade hidrográfica considerando-se as 64 microbacias foi de 10,5 para um desvio padrão de 4,9 (Tabela 30). Nota-se que há uma alta variação no conjunto de dados. Entre os limites de $10 \%$ e $90 \%$ dos casos ocorre uma variação de 12,2 entre o valor mais alto e o mais baixo.

Tabela 30: Dados estatísticos básicos e faixas de distribuição para Dh.

\begin{tabular}{l|r|r|r|r|r|r|r|r|}
\hline $\begin{array}{l}\text { BASIC } \\
\text { STATS }\end{array}$ & $\begin{array}{c}\text { número } \\
\text { de casos }\end{array}$ & média & mediana & $\begin{array}{c}\text { valor } \\
\text { minimo }\end{array}$ & $\begin{array}{c}\text { valor } \\
\text { máximo }\end{array}$ & $\begin{array}{c}\text { desvio } \\
\text { padrão }\end{array}$ & $\begin{array}{c}\text { v. } 1 \text { imite } \\
10 \%\end{array}$ & $\begin{array}{c}\text { v. limite } \\
90 \%\end{array}$ \\
\hline Dh & 64 & 10,5 & 9,1 & 1,4 & 25,0 & 4,9 & 5,2 & 17,4 \\
\hline
\end{tabular}

As microbacias com altos valores de densidade hidrográfica (B2, B8, B10, B54, B56 e B59) apresentam valores entre 17,5 e 25 (Figura 42). Delas, a que apresenta densidade hidrográfica mais elevada é a microbacia B59. As microbacias que apresentam os mais baixos valores de densidade hidrográfica são: B15, B19, B23, B24, B31e B41.

Faixas de distribuição para a Densidade Hidrográfica (Dh)

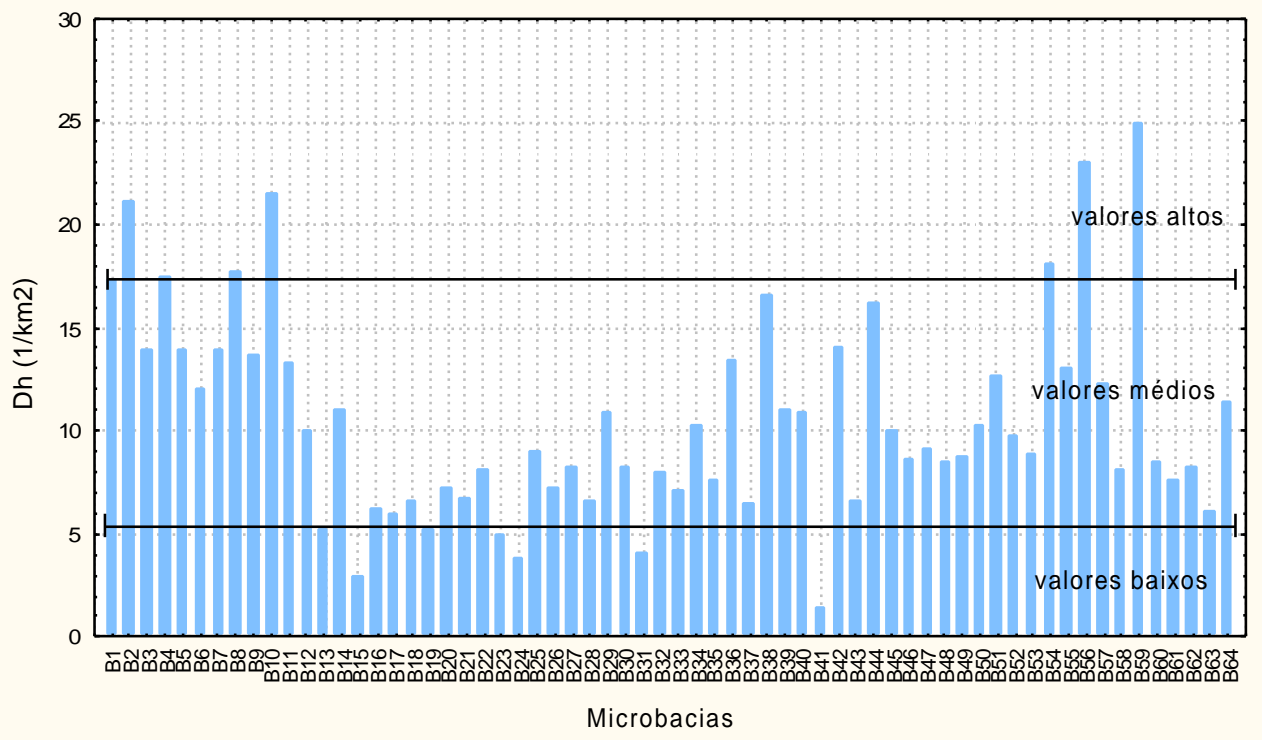

Figura 42: Valores da variável densidade hidrográfica (Dh) das microbacias da bacia do rio Capivari. 


\subsection{6 - Coeficiente de manutenção $(\mathrm{Cm})$}

O valor médio do coeficiente de manutenção para as microbacias é de 280 $\mathrm{m} / \mathrm{m}^{2}$, para um desvio padrão de $103 \mathrm{~m} / \mathrm{m}^{2}$ (Tabela 31). Há uma expressiva variação entre os dados e o intervalo entre os valores limites de $10 \%$ e $90 \%$ dos casos é de $178 \mathrm{~m} / \mathrm{m}^{2}$.

Tabela 31: Dados estatísticos básicos e faixas de distribuição para os valores de $\mathrm{Cm}$.

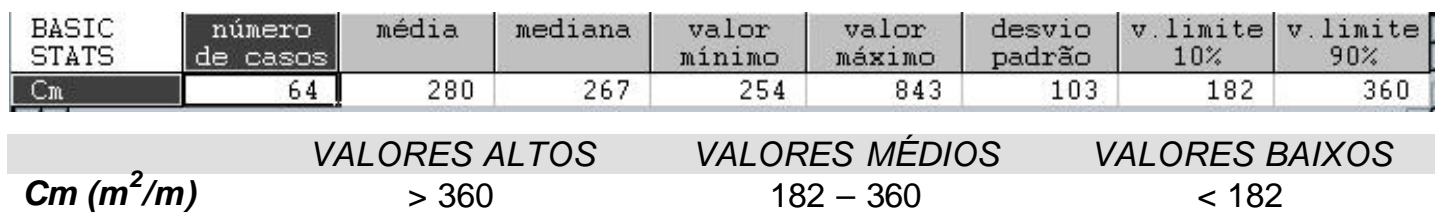

Dentre as seis microbacias que indicam altos valores de coeficiente de manutenção as microbacias B15, B19, B24, B31 e B33 apresentam valores que variam entre 380 e 500 (Figura 43). Já a microbacia B41 apresenta um coeficiente de manutenção superior a $800 \mathrm{~m} / \mathrm{m}^{2}$. As microbacias que apresentam os menores valores de coeficiente de manutenção são: B2, B4, B10, B56 e B59.

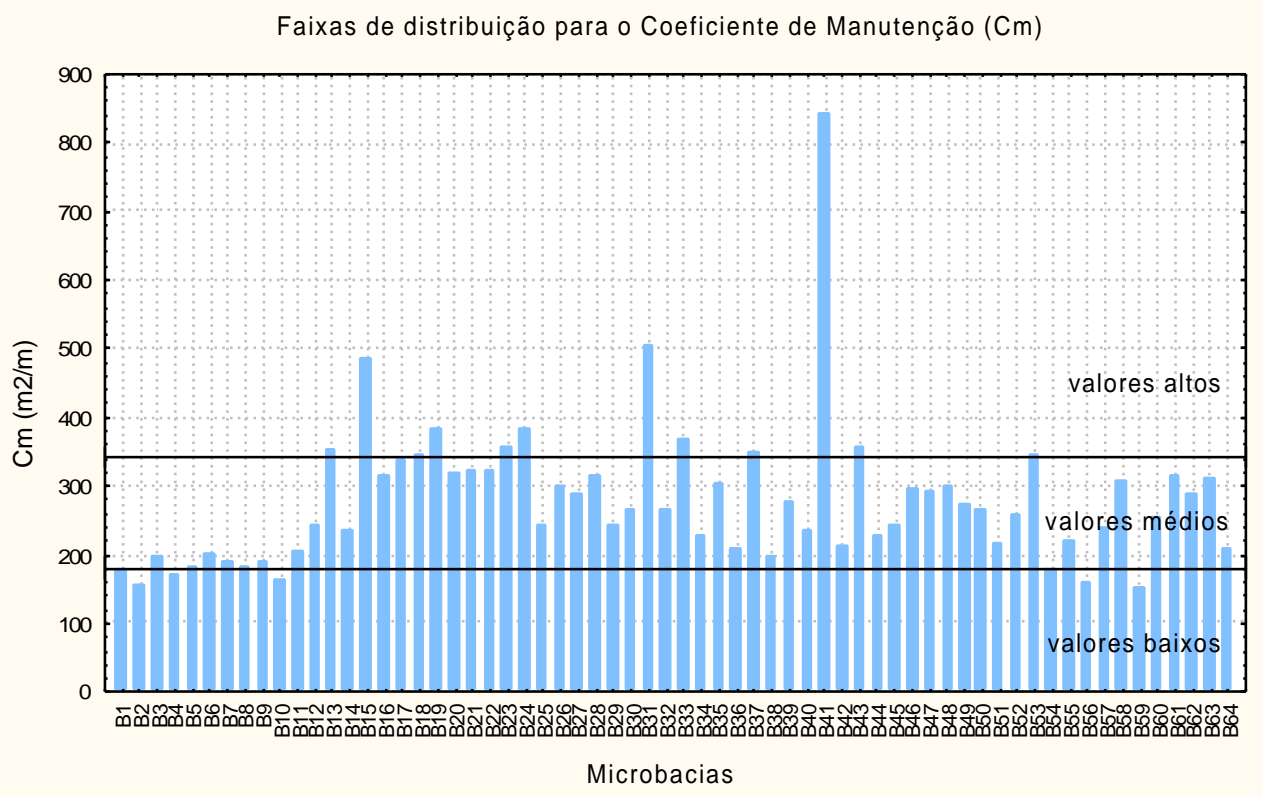

Figura 43: Valores da variável coeficiente de manutenção $(\mathrm{Cm})$ das microbacias da bacia do rio Capivari. 


\subsection{7 - Extensão do percurso superficial (Eps)}

A extensão do percurso superficial das 64 microbacias apresentam variações semelhantes às ocorridas na avaliação do coeficiente de manutenção. $O$ valor médio é de 140 metros $(\mathrm{m})$ para um desvio padrão de $52 \mathrm{~m}$ (Tabela 32). A variação no intervalo entre os valores limites de 10\% e 90\% dos casos é de $89 \mathrm{~m}$.

Tabela 32: Dados estatísticos básicos e faixas de distribuição para os valores de Eps.

\begin{tabular}{|c|c|c|c|c|c|c|c|c|}
\hline $\begin{array}{l}\text { BASIC } \\
\text { STATS }\end{array}$ & $\begin{array}{c}\text { número } \\
\text { de casos }\end{array}$ & média & mediana & $\begin{array}{l}\text { valor } \\
\text { mínimo }\end{array}$ & $\begin{array}{l}\text { valor } \\
\text { máximo }\end{array}$ & $\begin{array}{l}\text { desvio } \\
\text { padrão }\end{array}$ & \begin{tabular}{|c|} 
v. limite \\
$10 \%$
\end{tabular} & $\begin{array}{c}\text { v. } 1 \text { imite } \\
90 \%\end{array}$ \\
\hline Eps & 64 & 140 & 133 & 77 & 421 & 52 & 91 & 180 \\
\hline \multicolumn{9}{|c|}{ VALORES ALTOS } \\
\hline Eps (m) & & $>180$ & & & -180 & & $<91$ & \\
\hline
\end{tabular}

Dentre as seis microbacias que apresentam valores elevados de extensão do percurso superficial, as microbacias B15, B19, B24, B31 e B33 apresentam valores inferiores a 260 metros (Figura 44). A microbacia B41, assim como ocorreu na avaliação do coeficiente de manutenção, apresenta valor muito superior às demais (421metros). As microbacias que apresentam valores baixos para extensão do percurso superficial são: B2, B4, B10, B56 e B59.

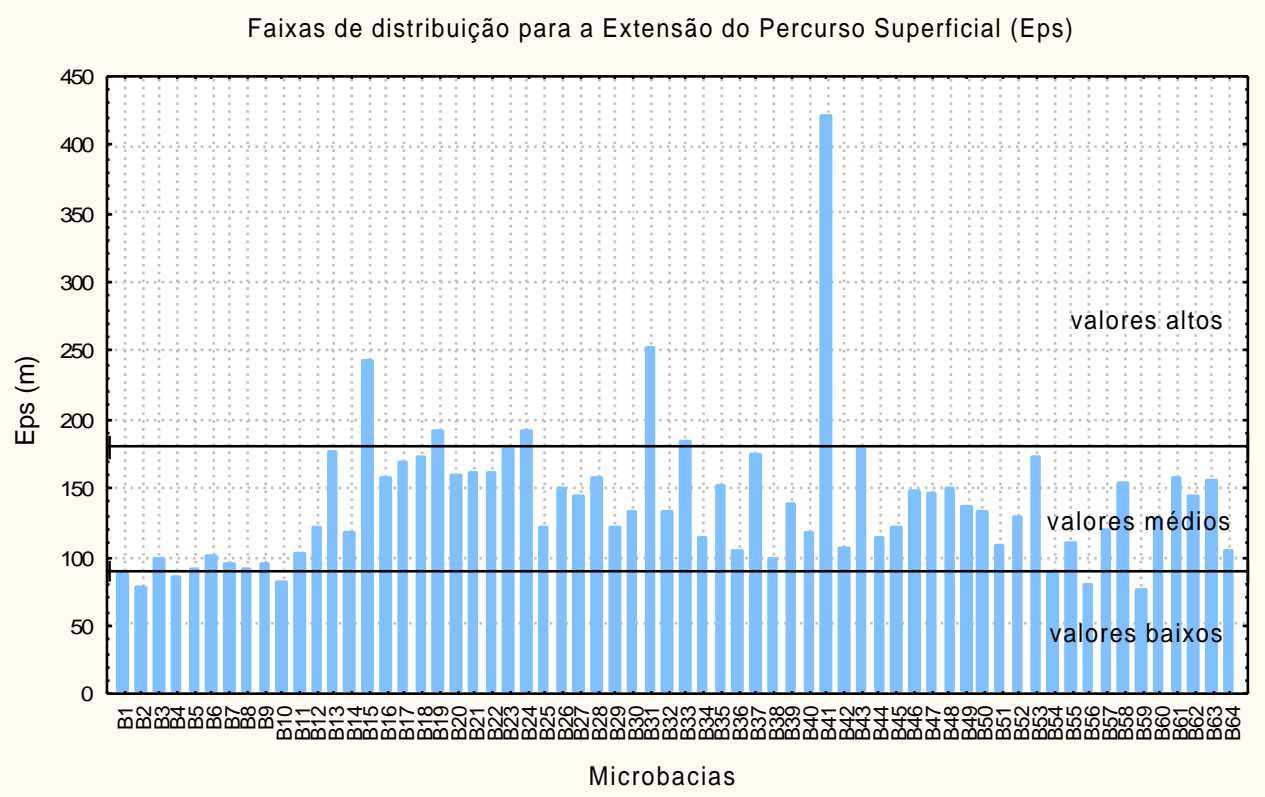

Figura 44: Valores da variável extensão do percurso superficial (Eps) das microbacias da bacia do rio Capivari. 


\subsection{8 - Textura topográfica $(\mathrm{Tt})$}

O valor médio para a textura topográfica na avaliação das 64 microbacias é de 8,0 para um desvio padrão de 2,7 e uma variação de 6,3 entre os valores limites de $10 \%$ e $90 \%$ dos casos (Tabela 33). Nota-se que não há uma correspondência entre os valores limitantes entre as classes aqui encontrados com as classes Grosseira, Média e Fina definidas por França (1968). Com exceção da microbacia B 41 , todas as outras enquadram-se nas classes Média ou Fina.

Tabela 33: Dados estatísticos básicos e faixas de distribuição para Tt.

\begin{tabular}{l|r|r|r|r|r|r|r|r|}
$\begin{array}{l}\text { BASIC } \\
\text { STATS }\end{array}$ & $\begin{array}{c}\text { número } \\
\text { de casos }\end{array}$ & média & mediana & $\begin{array}{c}\text { valor } \\
\text { minimo }\end{array}$ & $\begin{array}{c}\text { valor } \\
\text { máximo }\end{array}$ & $\begin{array}{c}\text { desvio } \\
\text { padrão }\end{array}$ & $\begin{array}{c}\text { v. limite } \\
10 \%\end{array}$ & $\begin{array}{c}\text { v. limite } \\
90 \%\end{array}$ \\
\hline \hline Tt & 64 & 8,0 & 7,6 & 2,0 & 14,3 & 2,7 & 5,4 & 11,7 \\
\hline
\end{tabular}

As microbacias que apresentam os maiores valores de textura topográfica são B2, B4, B10, B54, B56 e B59 (Figura 45). Os valores mais baixos são conferidos às microbacias $\mathrm{B} 15, \mathrm{~B} 19, \mathrm{~B} 24, \mathrm{~B} 31, \mathrm{~B} 33$ e $\mathrm{B} 41$, sendo que a microbacia B41 é a única classificada como de textura Grosseira, se considerada a classificação de França (1968).

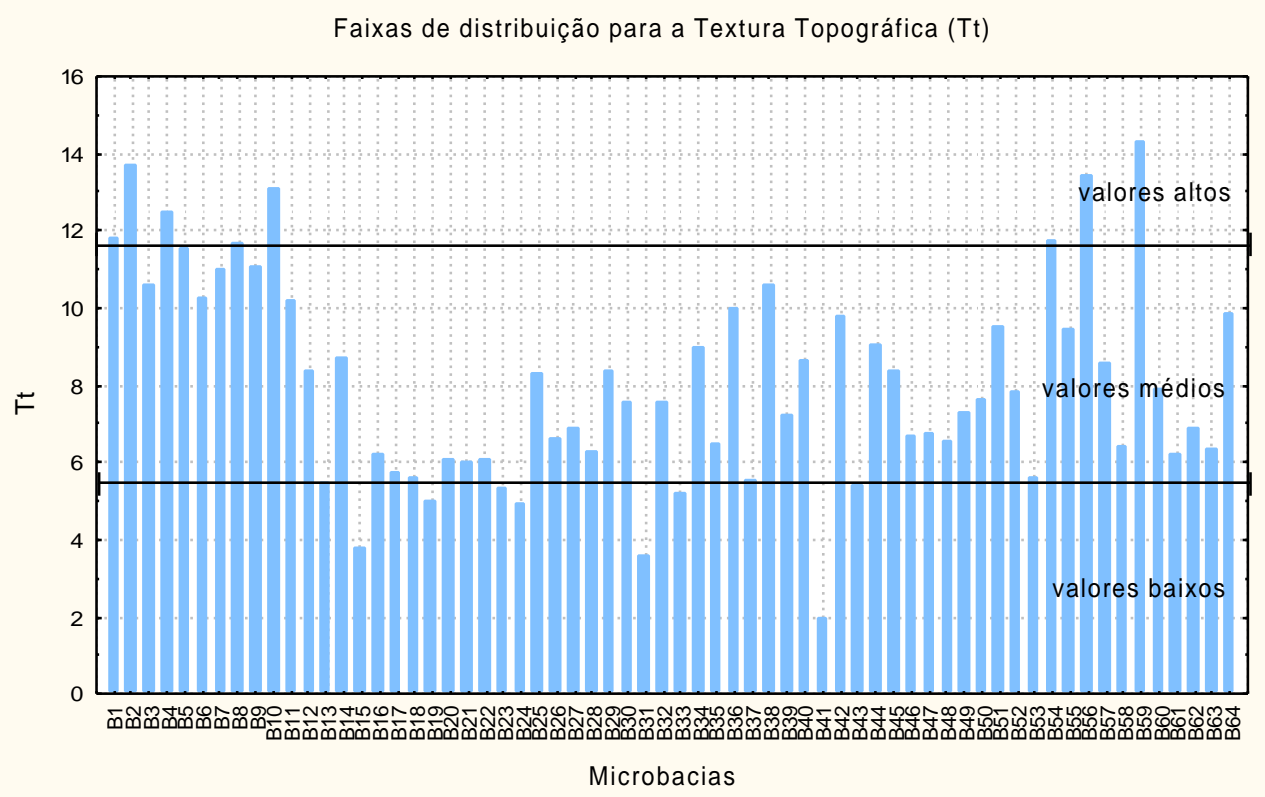

Figura 45: Valores da variável textura topográfica $(\mathrm{Tt})$ das microbacias da bacia do rio Capivari. 


\subsection{9 - Razão de bifurcação entre canais primeira e segunda ordens (Rb1-2)}

As microbacias apresentam como média da razão de bifurcação entre os canais de primeira e segunda ordens o valor 4,0 para um desvio padrão de 0,6 (Tabela 34). As variações entre os valores não são muito expressivas, principalmente quando considerado o intervalo entre os valores limites de $10 \% \mathrm{e}$ $90 \%$ dos casos, cuja variação é de 1,4.

Tabela 34: Dados estatísticos básicos e faixas de distribuição para os valores de $\mathrm{Rb} 1-2$.

\begin{tabular}{|c|c|c|c|c|c|c|c|c|}
\hline $\begin{array}{l}\text { BASIC } \\
\text { STATS } \\
\end{array}$ & $\begin{array}{l}\text { número } \\
\text { de casos }\end{array}$ & média & mediana & $\begin{array}{c}\text { valor } \\
\text { mínimo }\end{array}$ & $\begin{array}{l}\text { valor } \\
\text { máximo }\end{array}$ & $\begin{array}{l}\text { desvio } \\
\text { padrão }\end{array}$ & \begin{tabular}{|c|} 
v. limite \\
$10 \%$
\end{tabular} & $\begin{array}{l}\text { v. limite } \\
90 \%\end{array}$ \\
\hline $\mathrm{Rb} 1-2$ & 64 & 4,0 & 4,0 & 2,8 & 5.9 & 6 & 3,4 & 4.8 \\
\hline \multicolumn{4}{|c|}{ VALORES ALTOS } & \multicolumn{5}{|c|}{ VALORES BAIXOS } \\
\hline$R b 1-2$ & & $>4,8$ & & & $-4,8$ & & $<3,4$ & \\
\hline
\end{tabular}

As seis microbacias que apresentam altos valores para razão de bifurcação são: B13, B16, B22, B41, B42 e B47 (Figura 46). Destas, as microbacias B13, B41 e B42 apresentam razão de bifurcação próxima de 6,0. As microbacias que apresentam baixos valores de razão de bifurcação são: B15, B17, B25, B26 e B32.

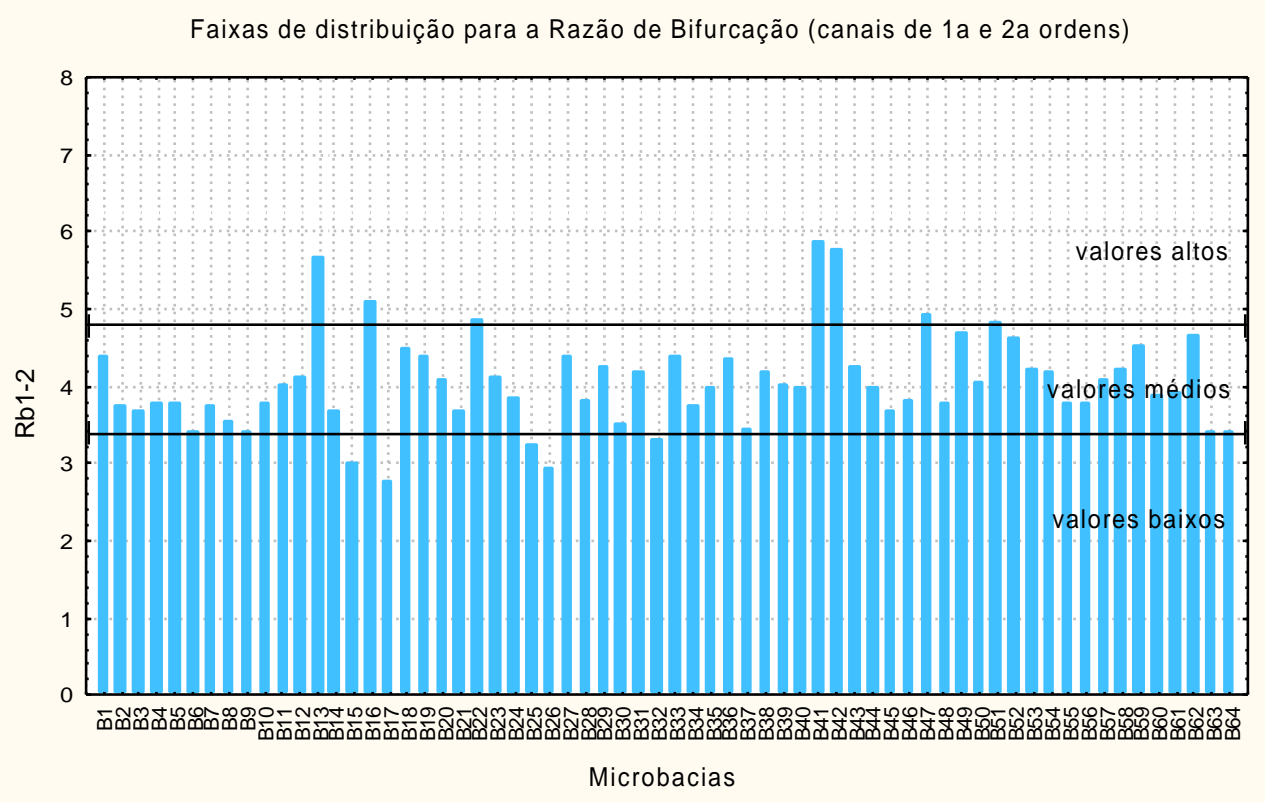

Figura 46: Valores da variável razão de bifurcação entre os canais de primeira e segunda ordens (Rb1-2) das microbacias da bacia do rio Capivari. 


\subsubsection{0 - Razão de comprimento médio entre canais de segunda e primeira ordens (RIm2-1)}

O valor médio da razão de comprimento médio para o conjunto das 64 microbacias é de 1,9 para um desvio padrão de 0,3 (Tabela 35). Observa-se que não há muita dispersão entre os dados, em especial entre os limites de 10\% e 90\% dos casos, cujo intervalo é de apenas 0,8 .

Tabela 35: Dados estatísticos básicos e faixas de distribuição para RIm2-1.

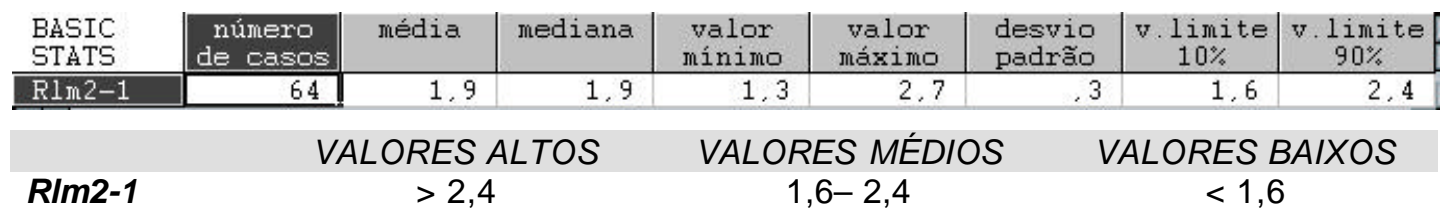

As seis microbacias que apresentam os valores elevados são as microbacias B13, B18, B22, B31, B42 e B47 (Figura 47) e as que apresentam os valores mais baixos são B12, B17, B21, B23, B26 e B53.

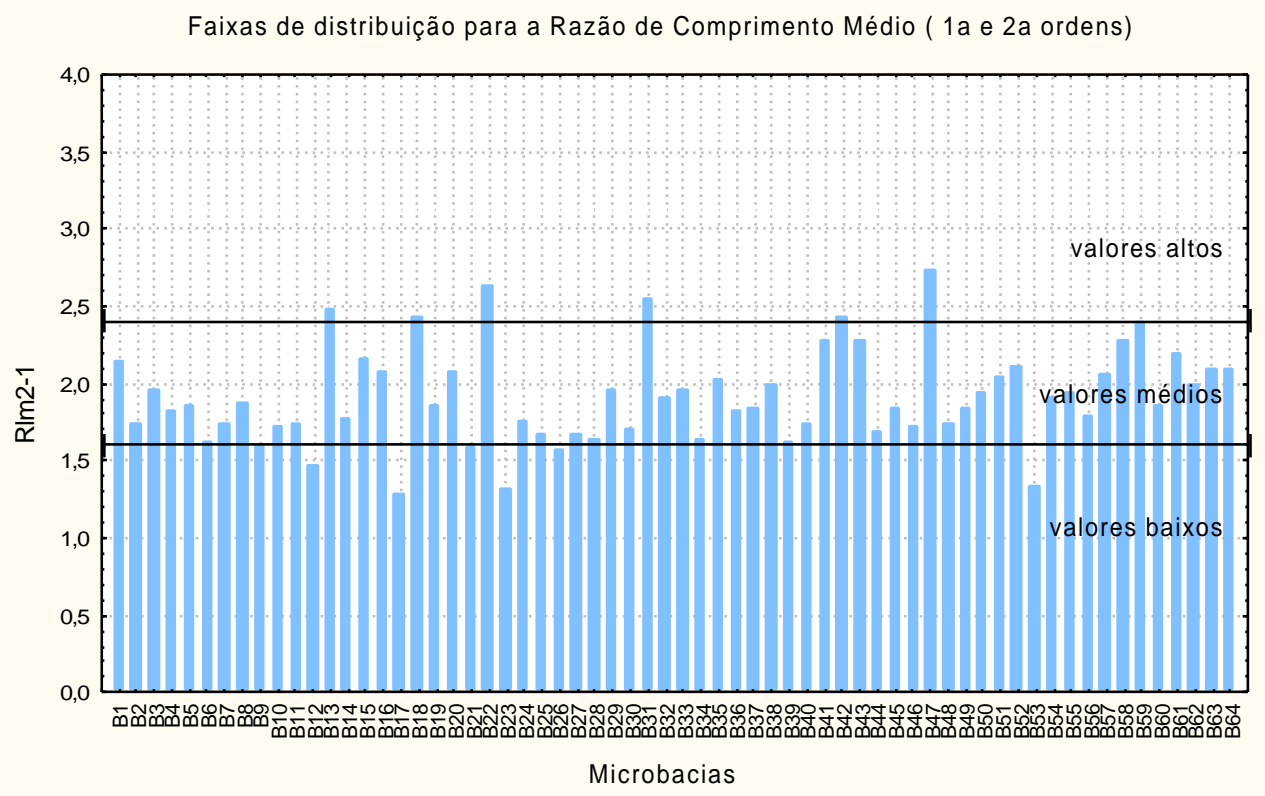

Figura 47: Valores da variável razão de comprimento médio entre os canais de segunda e de primeira ordens (RIm2-1) das microbacias da bacia do rio Capivari. 


\section{3 - Avaliação das variáveis morfológicas}

\subsection{1 - Relação entre as variáveis morfológicas}

A Figura 48 apresenta uma matriz que mostra em pequenos gráficos as relações existentes entre as variáveis área, índice de circularidade (Ic), relação de relevo $(\mathrm{Rr})$, índice de sinuosidade (Si) e comprimento do canal principal (L.rio). Além da previsível relação área x comprimento do canal principal, pode-se observar tendências de comportamento para as relações área x relação de relevo e índice de sinuosidade x comprimento do canal principal.

Matriz gráfica - variáveis morfológicas

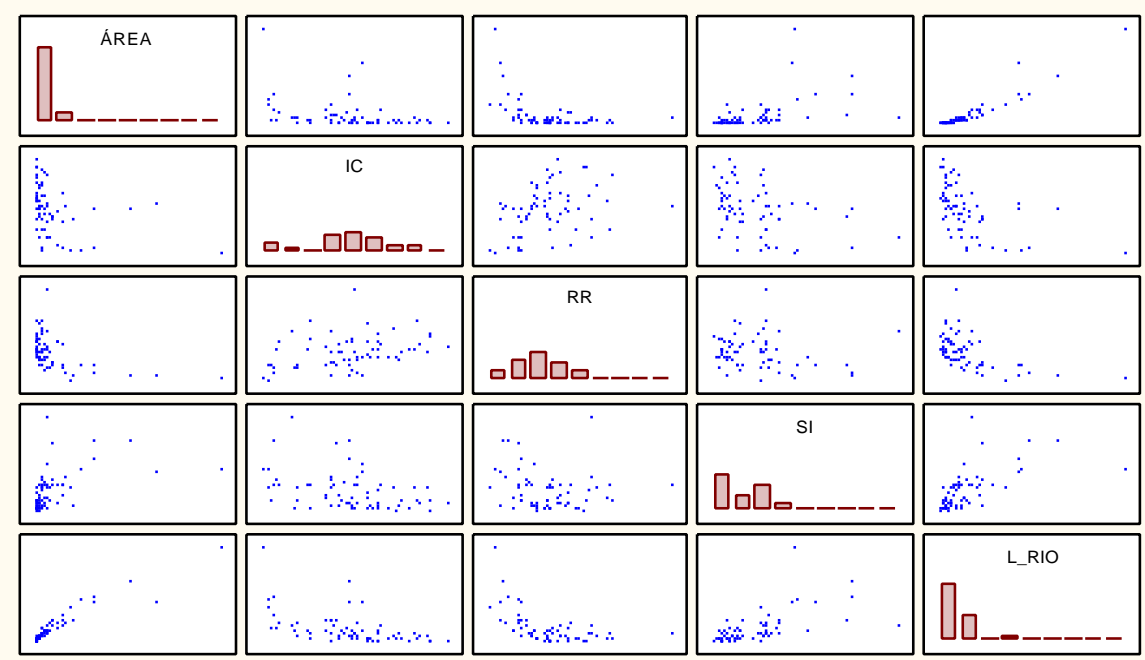

Figura 48: Matriz gráfica com dados morfológicos das 64 microbacias da bacia do rio Capivari.

O gráfico área x relação de relevo (Figura 49) ilustra com detalhe a tendência de comportamento entre estas variáveis. Todas as microbacias com valores baixos de $\mathrm{Rr}$ compreendem áreas superiores a $35 \mathrm{~km}^{2}$, em especial as microbacias B27, B46 e B50 que apresentam área superior a $90 \mathrm{~km}^{2}$; e todas as microbacias classificadas com valores altos de $\mathrm{Rr}$ compreendem áreas inferiores a $20 \mathrm{~km}^{2}$, como a bacia B6, que apresenta relação de relevo igual a $53,4 \mathrm{~m} / \mathrm{km}$ e compreende uma área de $16 \mathrm{~km}^{2}$. 


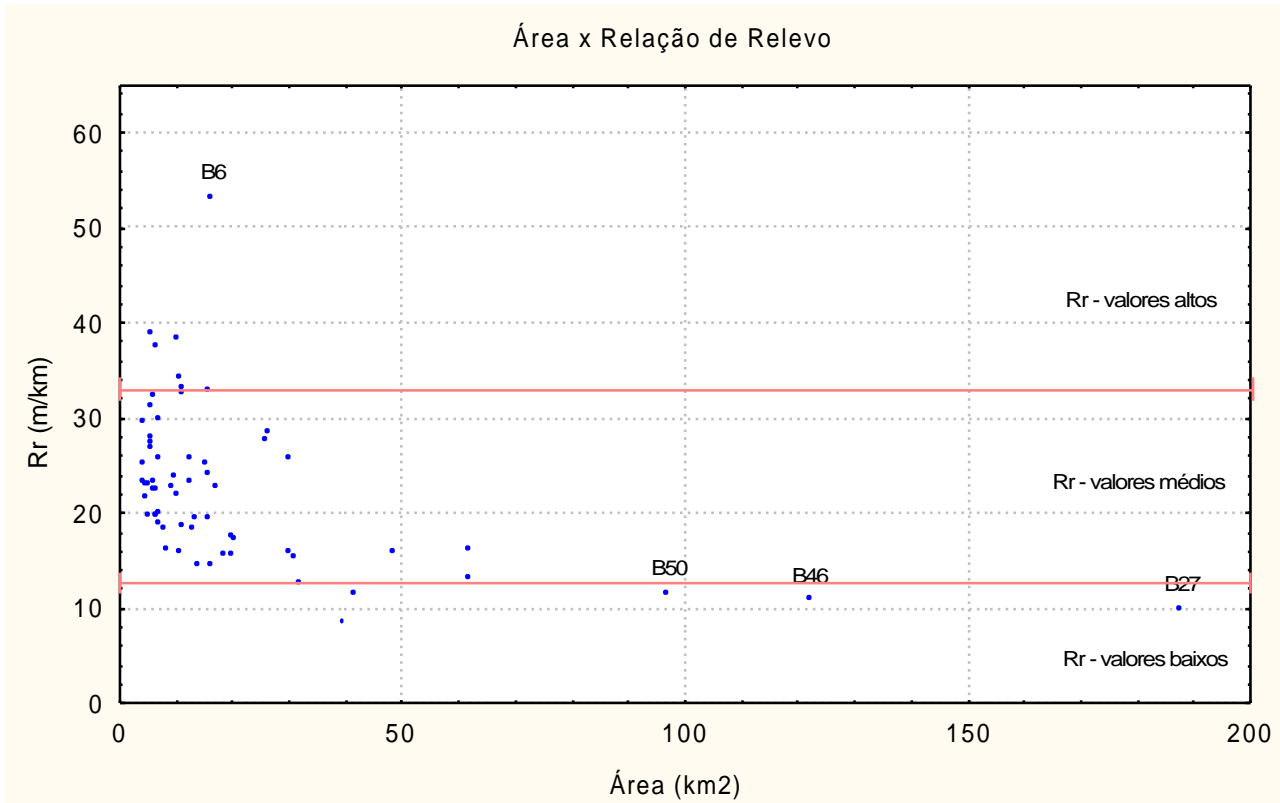

Figura 49: Relação entre área e relação de relevo para as 64 microbacias da bacia do rio Capivari.

O gráfico comprimento do rio principal x índice de sinuosidade (Figura 50) apesar de apresentar dados relativamente dispersos, mostra uma tênue tendência de crescimento linear do índice de sinuosidade com o comprimento do canal; ficam fora deste padrão as microbacias B27, que é uma microbacia anômala, por apresentar área muito superior a todas as outras, e a microbacia B1, que corresponde à região de cabeceira do rio Capivari.

As microbacias com valores baixos de Si possuem canais principais com comprimento inferior a $8 \mathrm{~km}$ ou, preferencialmente, inferior a $5 \mathrm{~km}$. Microbacias com altos valores de Si apresentam uma certa dispersão quanto ao comprimento dos seus canais principais, entretanto, são todos maiores que $8 \mathrm{~km}$. As microbacias B50 e B22, cujas extensões de canais principais são superiores a $20 \mathrm{~km}$, apresentam índice de sinuosidade maior que 1,7.

Na relação com a ordem dos canais (Figura 51) nota-se que os mais altos índices de sinuosidade correspondem a canais com níveis hierárquicos mais elevados. Das seis microbacias com valores elevados de índice de sinuosidade, cinco correspondem a canais de quinta ou sexta ordem hierárquica (B1, B22, B50, $\mathrm{B} 54, \mathrm{~B} 60)$. 
Comprimento do Canal Principal x Sinuosidade (Si)

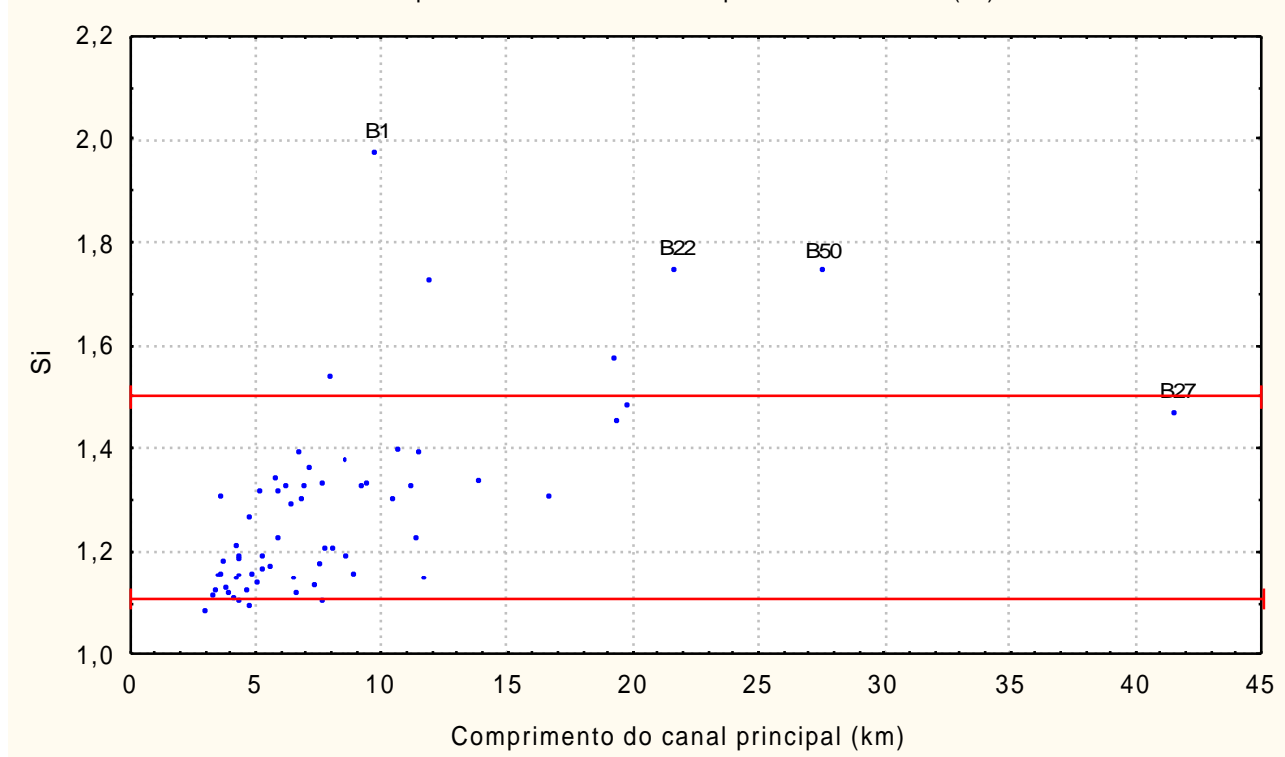

Figura 50: relação entre comprimento do canal principal e índice de sinuosidade para as 64 microbacias da bacia do rio Capivari.

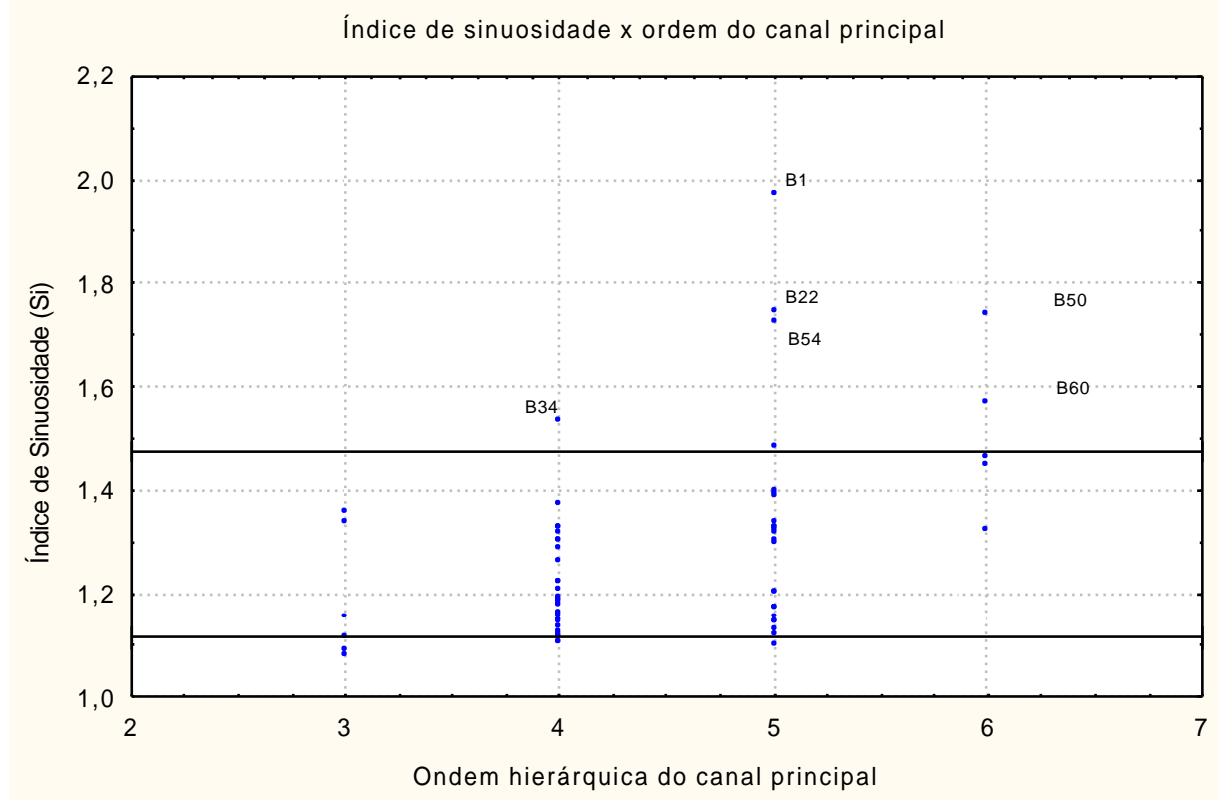

Figura 51: Relação entre ordem do canal principal e índice de sinuosidade para as 64 microbacias da bacia do rio Capivari. 


\subsection{2 - Relações entre as variáveis morfológicas e a litologia}

Para analisar as relações existentes entre as variáveis morfológicas e a litologia procurou-se, inicialmente, classificar as microbacias quanto ao substrato rochoso predominante. Assim, considerou-se uma microbacia tipicamente constituída por uma determinado grupo litológico quando mais de $80 \%$ da sua área está coberta por este grupo litológico. Litologias do Embasamento, Rochas Sedimentares Intercaladas e Rochas Sedimentares Areníticas puderam ser analisadas por apresentar um número significativo de microbacias com predominância destes tipos litológicos. Os outros grupos litológicos, menos expressivos na bacia do Capivari, não foram analisados.

A Figura 52 apresenta uma matriz gráfica com as relações existentes entre as variáveis morfológicas índice de circularidade (Ic), relação de relevo (Rr) e índice de sinuosidade $(\mathrm{Si})$ com as variáveis EMBASAM\%, INTERC\% e ARENITO\% que referemse à porcentagem de área ocupada em cada microbacia pelas litologias do Embasamento Cristalino, Rochas Sedimentares Intercaladas, e Rochas Areníticas, respectivamente. Observam-se algumas tendências de comportamento tanto para as microbacias do Embasamento Cristalino quanto para microbacias onde predominam substrato de rochas sedimentares areníticas e intercaladas.

Matriz gráfica - variáveis morfológicas x substrato rochoso

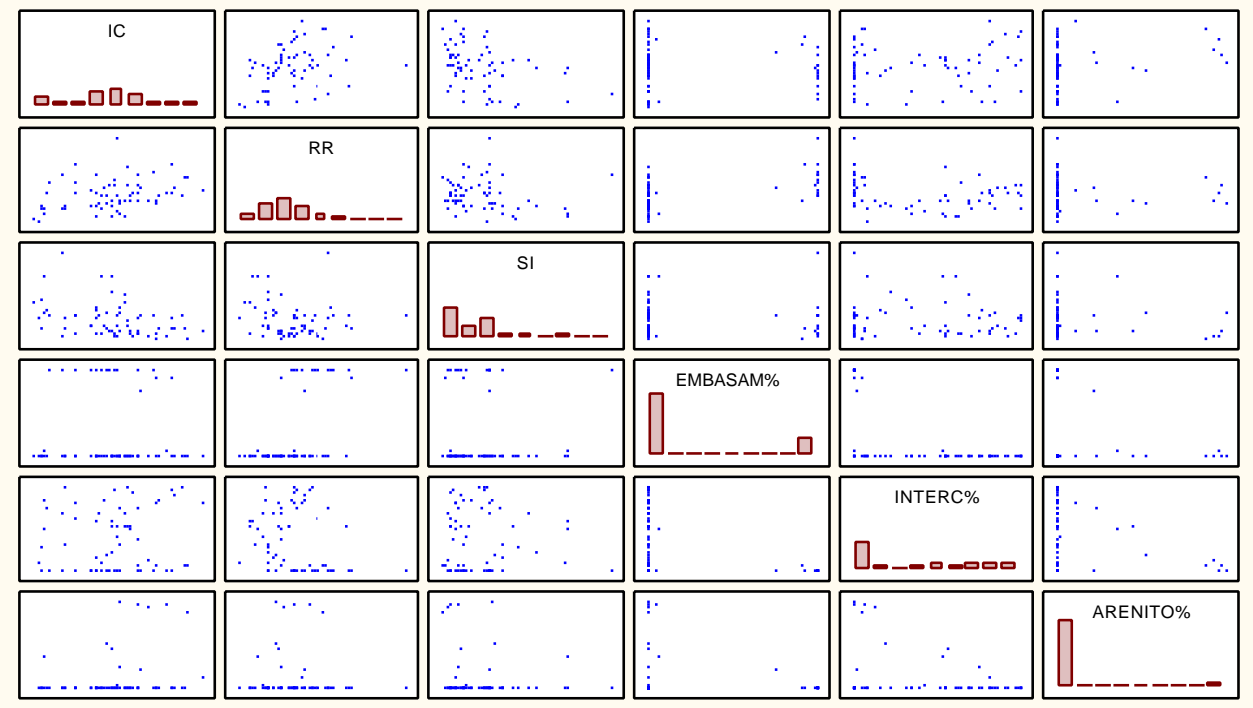

Figura 52: Matriz gráfica com dados morfológicos e do substrato rochoso das 64 microbacias da bacia do rio Capivari. 
Com relação ao índice de circularidade, observa-se que há uma tendência de comportamento apenas para as microbacias areníticas, que apresentam valores médios e altos. A Figura 53 mostra que das cinco microbacias areníticas (assinaladas no gráfico em vermelho), quatro apresentam índice de circularidade superior a 0,6, sendo que a B20 apresenta índice superior a 0,7 e encontra-se na faixa de valores altos.

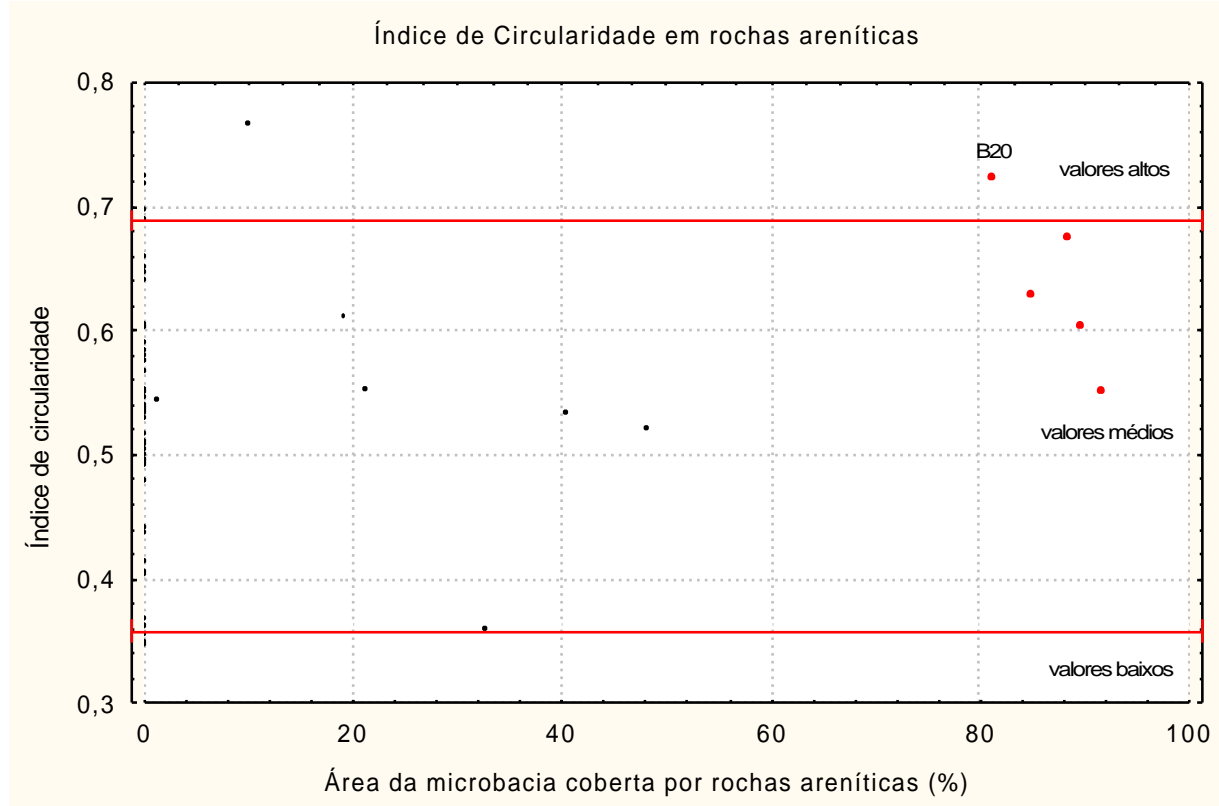

Figura 53: Relação entre microbacias areníticas e o índice de circularidade.

A variável relação de relevo apresenta uma boa correspondência com as microbacias onde predomina um único tipo litológico. As microbacias onde predominam rochas areníticas ou rochas sedimentares intercaladas apresentam uma baixa dispersão com relação a esta variável, como pode ser observado na matriz gráfica da Figura 52.

Com relação às microbacias do Embasamento (assinaladas no gráfico da Figura 54 com pontos vermelhos) observa-se que, apesar de ocorrer uma certa dispersão entre os dados de $\mathrm{Rr}$, todas elas apresentam valores médios ou altos, sendo que, dentre as seis microbacias com valores altos de $\mathrm{Rr}$, cinco são do Embasamento (B14, B11, B6, B2 e B1). 


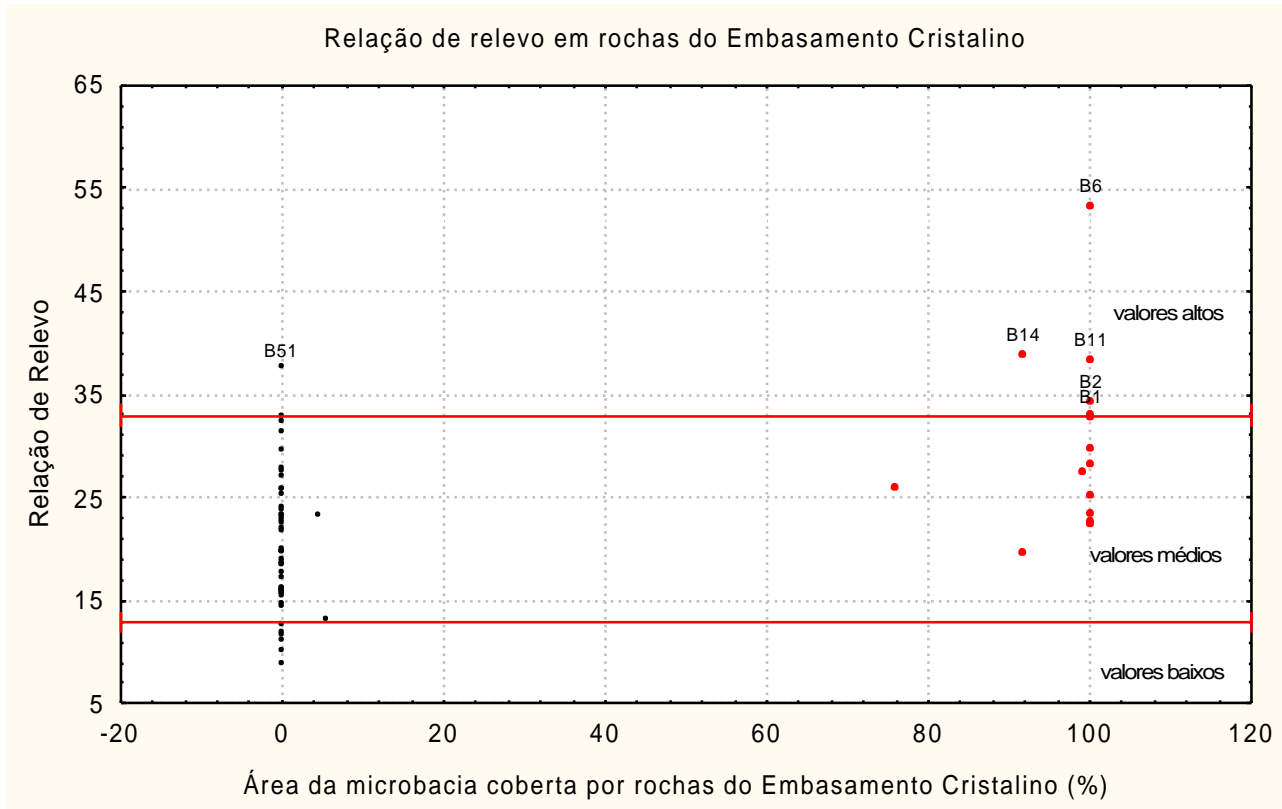

Figura 54: Relação entre microbacias do Embasamento e a relação de relevo.

Quanto ao índice de sinuosidade, tanto nas microbacias do Embasamento, quanto nas microbacias de rochas areníticas e intercaladas predominam valores médios e baixos. observa-se nas Figuras 55 e 56 que dentre as seis microbacias com os menores valores, três são microbacias areníticas (B20, B19 e B15) e duas do Embasamento (B13 e B8).

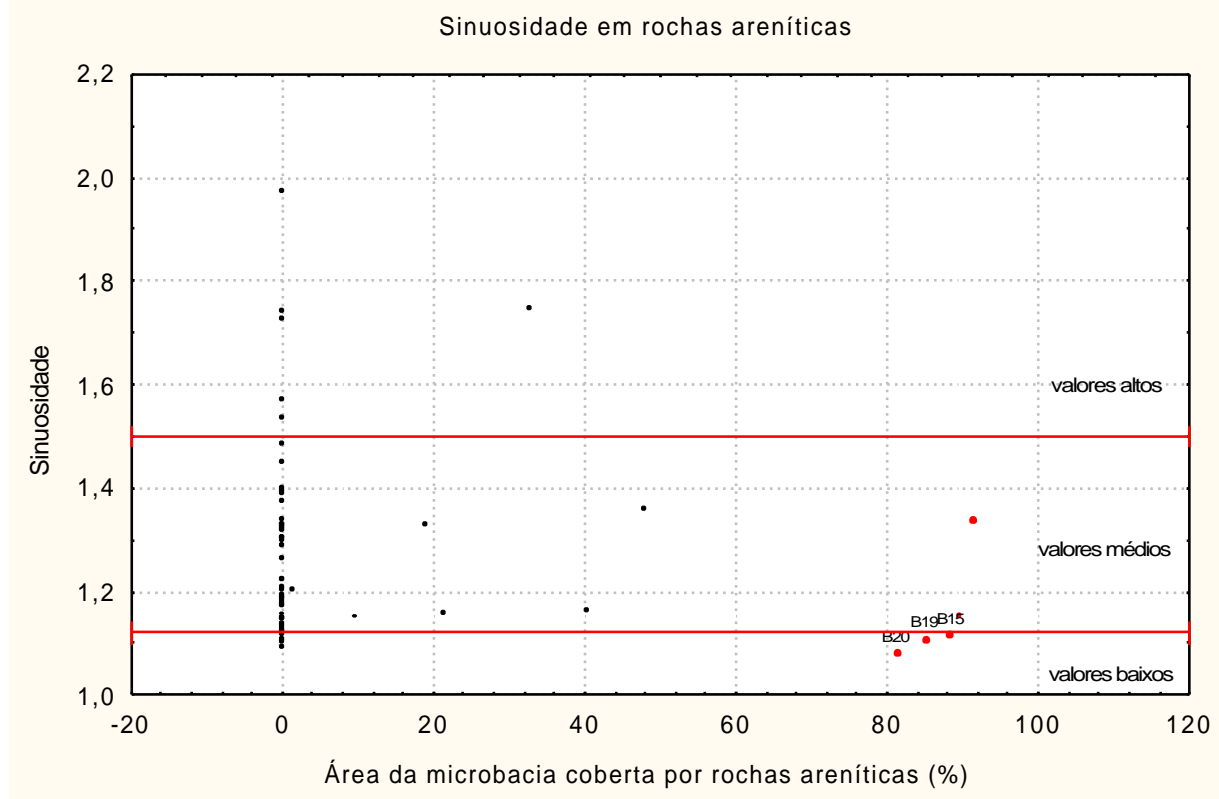

Figura 55: Relação entre microbacias areníticas e o índice de sinuosidade. 


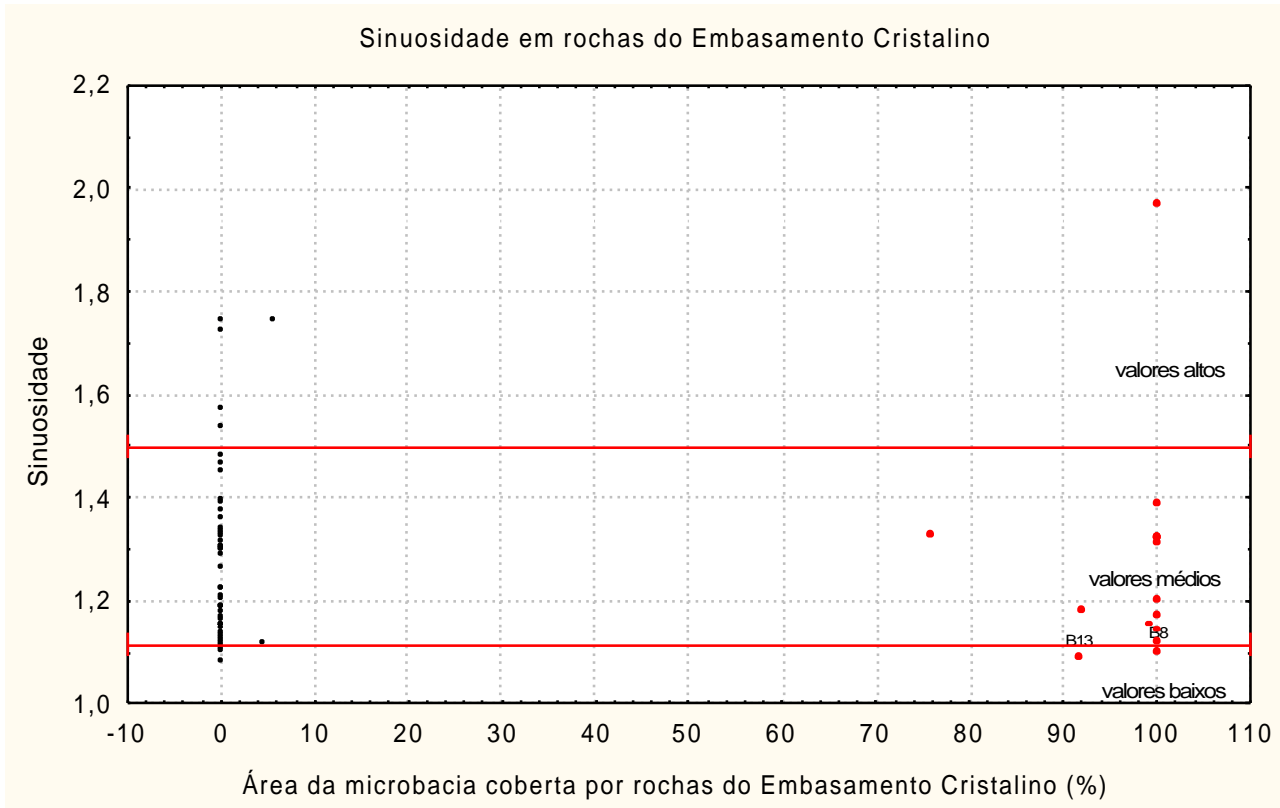

Figura 56: Relação entre microbacias do Embasamento e o índice de sinuosidade.

\subsection{3 - Influência das variáveis morfológicas na avaliação das alterações das microbacias}

As variáveis morfológicas, apesar de não terem sido utilizadas diretamente na análise temporal para a avaliação das alterações ocorridas nas microbacias, podem contribuir para explicar ou justificar determinadas alterações. Algumas relações entre estas variáveis, bem como entre elas e algumas características dimensionais (área e comprimento do canal principal) e litológicas são observadas.

Quanto à variável relação de relevo, pode-se observar que ela é fortemente influenciada pelas dimensões das microbacias. Nas microbacias de pequena dimensão predominam canais mais curtos e de menor grau hierárquico e a distância entre o divisor de águas e a desembocadura é menor, conduzindo, assim, a declividades médias mais elevadas.

Observa-se ainda uma relação desta variável com a litologia. Nas microbacias com predomínio de um único tipo litológico, a dispersão entre os dados é pequena e os índices de relação de relevo são mais altos nas microbacias com predomínio de rochas granito-gnáissicas do Embasamento Cristalino. Nestas áreas o relevo é tipicamente montanhoso e com declividades mais elevadas. 
O índice de sinuosidade tende a ser maior para rios de maior extensão e de maior grau hierárquico. Além do controle geológico e estrutural, a própria estruturação dos canais que formam o rio, que a cada bifurcação o desvia do vetor principal, pode estar contribuindo para determinar uma maior sinuosidade para rios de maior grau hierárquico.

O índice de circularidade não apresenta qualquer relação com os outros índices morfométricos ou com a dimensão das microbacias. No geral as microbacias apresentam formas alongadas. Apenas quatro das sessenta e quatro microbacias apresentam índice de circularidade superior a 0,7, o que, em associação com outros fatores poderia favorecer a ocorrência de inundações.

\section{4 - Avaliação das variáveis da rede de drenagem}

\subsection{1 - Relação entre as variáveis da rede de drenagem e variáveis morfológicas}

A matriz gráfica da Figura 57 mostra as relações existentes entre variáveis da rede de drenagem e entre variáveis da rede de drenagem e morfológicas. $\mathrm{O}$ alto grau de correlação entre as variáveis densidade de drenagem (Dd), coeficiente de manutenção $(\mathrm{Cm})$, extensão do percurso superficial (Eps) e textura topográfica (Tt), era previsível, uma vez que $\mathrm{Cm}$, Eps e Tt são variáveis dependentes de Dd.

Observa-se, também, uma alta correlação destas variáveis com Dh, indicando uma relação entre parâmetros dimensionais (mensurado por $\mathrm{Dd}, \mathrm{Cm}$, Eps e Tt) e adimensionais (mensurado por Dh). Matrizes numéricas que expressam o alto grau de correlação entre estas variáveis estão apresentadas e discutidas no Capítulo 5. No presente capítulo são enfocadas relações com menores coeficientes de correlação, mas que podem contribuir para explicar as alterações ocorridas nas microbacias.

A matriz gráfica não indica algum tipo de tendência entre as variáveis da rede de drenagem e as variáveis área, lc e Si. O gráfico da Figura 58 ilustra as 
relações entre área e densidade de drenagem, mostrando que tanto microbacias pequenas ou médias (área menor que $40 \mathrm{~km}^{2}$ ) podem apresentar valores altos, médios ou baixos de densidade de drenagem. As microbacias consideradas de grande porte (com área superior a $40 \mathrm{~km}^{2}$ ), apresentam valores médios de densidade de drenagem, variando de 3,0 a $4,0 \mathrm{~km} / \mathrm{km}^{2}$.

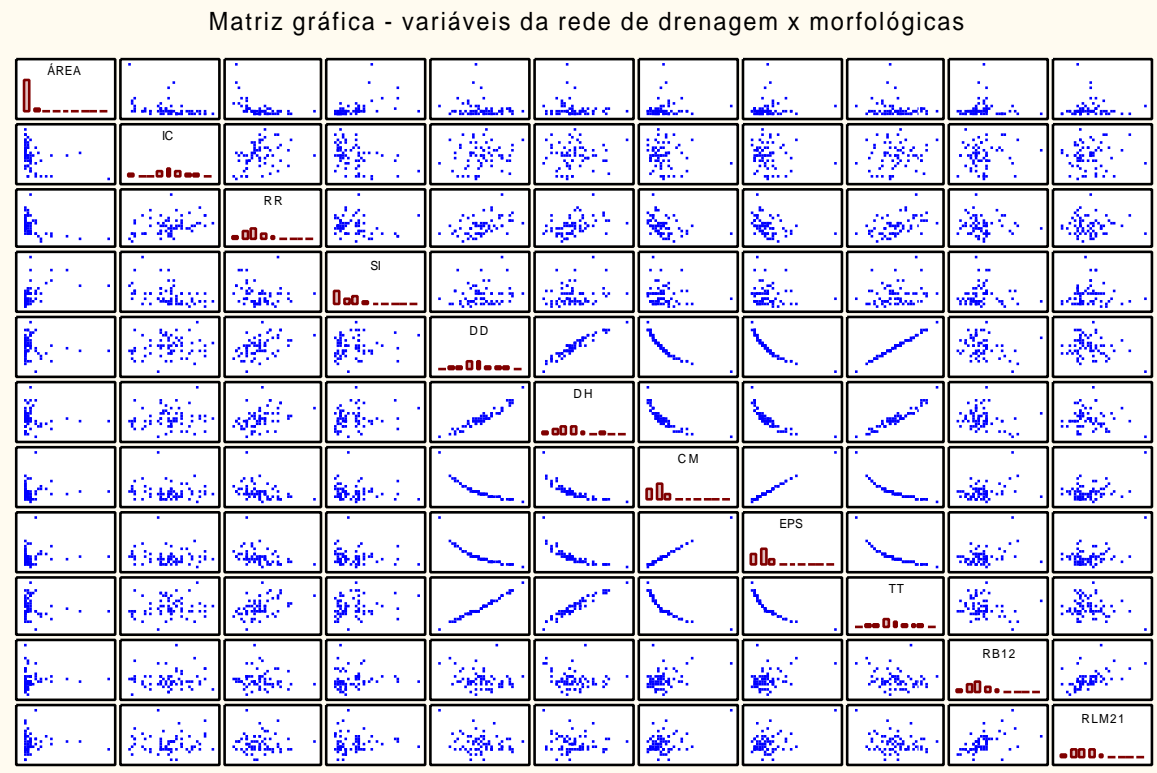

Figura 57: Matriz gráfica com dados morfológicos e da rede de drenagem.

Densidade de Drenagem x Área

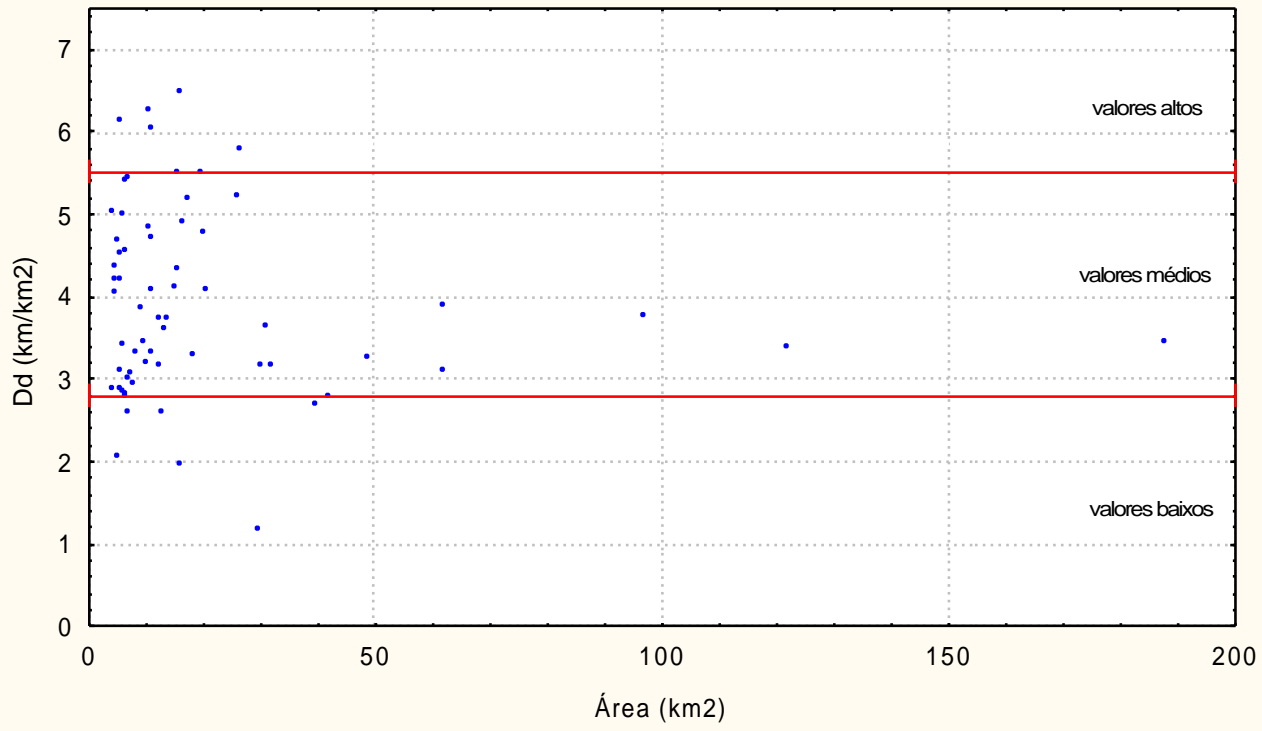

Figura 58: Relação entre área e densidade de drenagem. 
A variável relação de relevo apresenta uma tênue tendência de crescimento linear com a densidade de drenagem e com a densidade Hidrográfica. O gráfico da Figura 59 mostra que as cinco microbacias com maiores valores de densidade de drenagem apresentam relação de relevo maior que $24 \mathrm{~m} / \mathrm{km}$, enquanto que cinco das seis microbacias com valores mais baixos apresentam relação de relevo inferior a $20 \mathrm{~m} / \mathrm{Km}$.

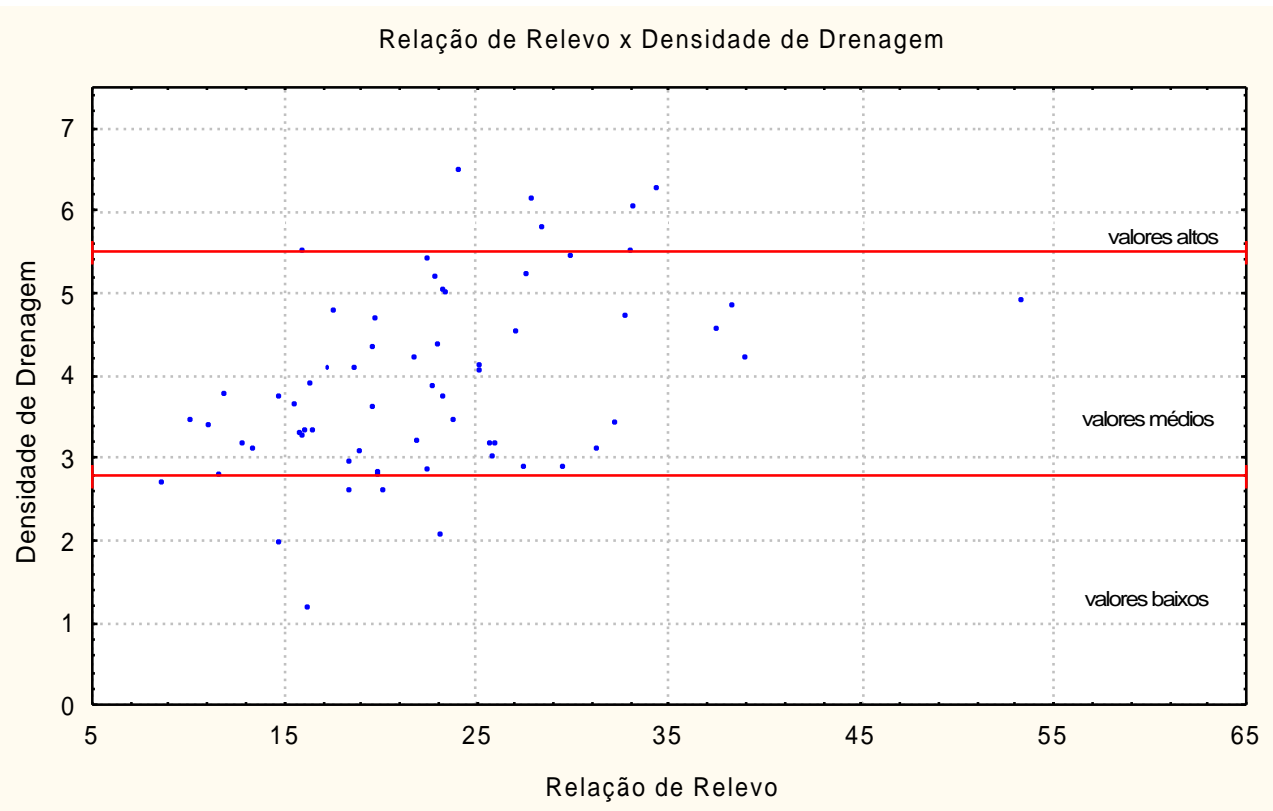

Figura 59: Relação entre relação de relevo e densidade de drenagem.

O gráfico da Figura 60 mostra o resultado da análise entre a razão de comprimento médio (RIm2-1) e a razão de bifurcação entre canais de primeira e segunda ordens. Observa-se uma tendência de crescimento linear entre estas duas variáveis, indicando que altos valores de Rb1-2, implicariam em altos valores de RIm2-1. Algumas das microbacias, entretanto, não se enquadram perfeitamente nesta tendência. Microbacias como B53, B23 e B12 apresentam valores muito baixos de razão de comprimento médio para valores médios de razão de bifurcação, enquanto a microbacia B15 apresenta uma alta razão de comprimento médio para uma baixa razão de bifurcação. 


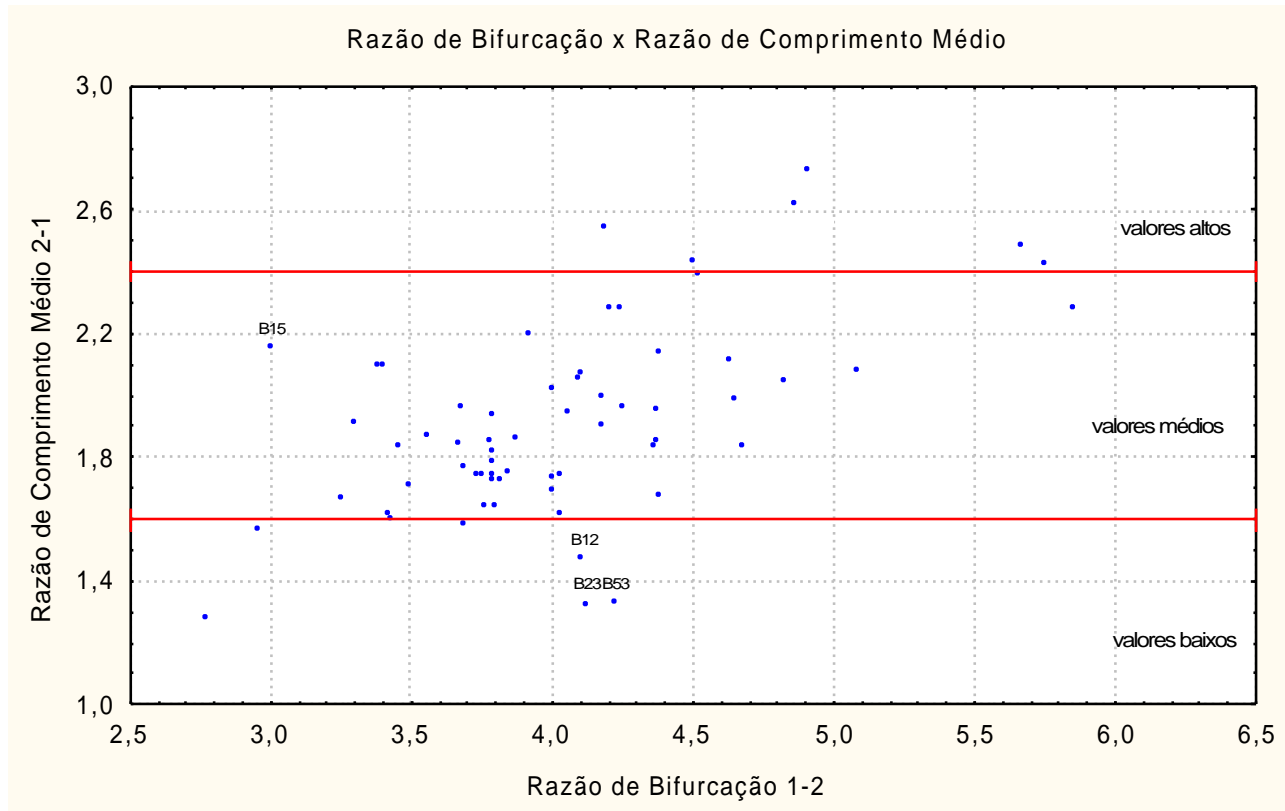

Figura 60: Relação entre razão de bifurcação (Rb1-2) e razão de comprimento médio (RIm2-1) para as 64 microbacias da bacia do rio Capivari.

\subsection{2 - Relação entre variáveis da rede de drenagem e a litologia}

Para a análise das relações entre as variáveis da rede de drenagem e a litologia foi necessária a classificação das microbacias quanto ao substrato rochoso predominante, nos moldes já descritos no sub-capítulo 6.3.2, onde uma microbacia é dita tipicamente constituída por uma determinado grupo litológico quando mais de $80 \%$ da sua área está coberta por este grupo litológico.

A matriz gráfica da Figura 61 descreve as relações entre as variáveis densidade de drenagem $(\mathrm{Dd})$, densidade Hidrográfica $(\mathrm{Dd})$, razão de bifurcação (Rb1-2) e razão de comprimento médio (RIm2-1) com as variáveis EMBASAM\%, INTERC\% e ARENITO\% que se referem à porcentagem de área ocupada em cada microbacia por litologias do Embasamento Cristalino, Rochas Sedimentares Finas, e Rochas Areníticas, respectivamente.

Os gráficos das Figuras 62 e 63 permitem uma análise mais detalhada da densidade de drenagem, conforme o tipo litológico predominante. Observa-se que as microbacias areníticas apresentam valores inferiores aos das bacias do 
Embasamento. As densidades de drenagem das microbacias areníticas variam de 2,1 a 3,1 km/ km2, sendo que duas delas (B19, B15) apresentam-se na faixa de valores baixos. Nas microbacias do Embasamento os valores variam de 2,7 a 6,3 e quatro delas (B10, B4, B2, B1) apresentam-se na faixa de valores altos .

Matriz gráfica - variáveis da rede de drenagem $x$ litologia

\begin{tabular}{|c|c|c|c|c|c|c|}
\hline 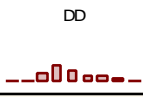 & $\therefore \mathrm{A}^{\prime}$ & 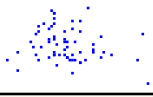 & $\because$ & $\vdots$ & {$\left[\begin{array}{c}i \\
1 \\
i \\
i .\end{array}\right.$} & \\
\hline$\therefore$ & 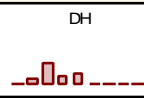 & $\begin{array}{l}0 \\
\vdots \\
\vdots\end{array}$ & $\therefore$ & !́: & $\therefore$ & $\because$ \\
\hline$\because$ & 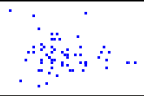 & 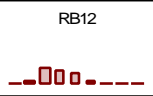 & $\because$ & i. & $\because$ & $\begin{array}{lll} & & \\
\text { i } & \cdot & \\
& & \\
\end{array}$ \\
\hline$\therefore$ & $\begin{array}{ll}0 \\
\because\end{array}$ & 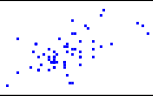 & $\begin{array}{c}\text { RLM21 } \\
\text {-_Dou----- }\end{array}$ & & & i. \\
\hline $\begin{array}{r}\cdot \cdot \cdot \cdots \\
\therefore+\cdots \\
\end{array}$ & 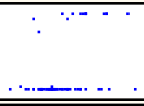 & 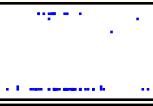 & $-\cdots \ldots$ & $\prod_{\text {EMBASAM\% }}^{\text {EM }}$ & 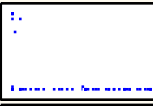 & $\ldots$ \\
\hline 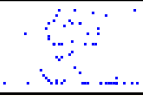 & 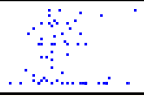 & 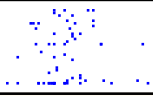 & 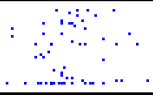 & i. & $\begin{array}{c}\text { INTERC\% } \\
\text { D_-_-_-_- }\end{array}$ & \begin{tabular}{|lll} 
& & \\
$\mathbf{i}$ & $\cdots$ & \\
$\mathbf{i}$ & & $\cdots$ \\
$\mathbf{i}$ &. & \\
\end{tabular} \\
\hline $\begin{array}{l}\cdot \because \\
\ddots \\
\vdots \\
. \\
-\end{array}$ & $\begin{array}{l}\because- \\
\because \\
\because \\
\cdot\end{array}$ & 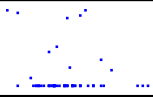 & $\begin{array}{ll} & \cdot \\
. & \\
\cdot & \cdot \\
\end{array}$ & $\begin{array}{l}\vdots \cdot \\
\vdots \\
\vdots\end{array}$ & 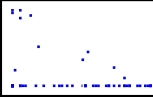 & $\prod_{--------}^{\mathrm{ARENITO} \%}$ \\
\hline
\end{tabular}

Figura 61: Matriz gráfica com dados da rede de drenagem e do substrato rochoso das 64 microbacias da bacia do rio Capivari.

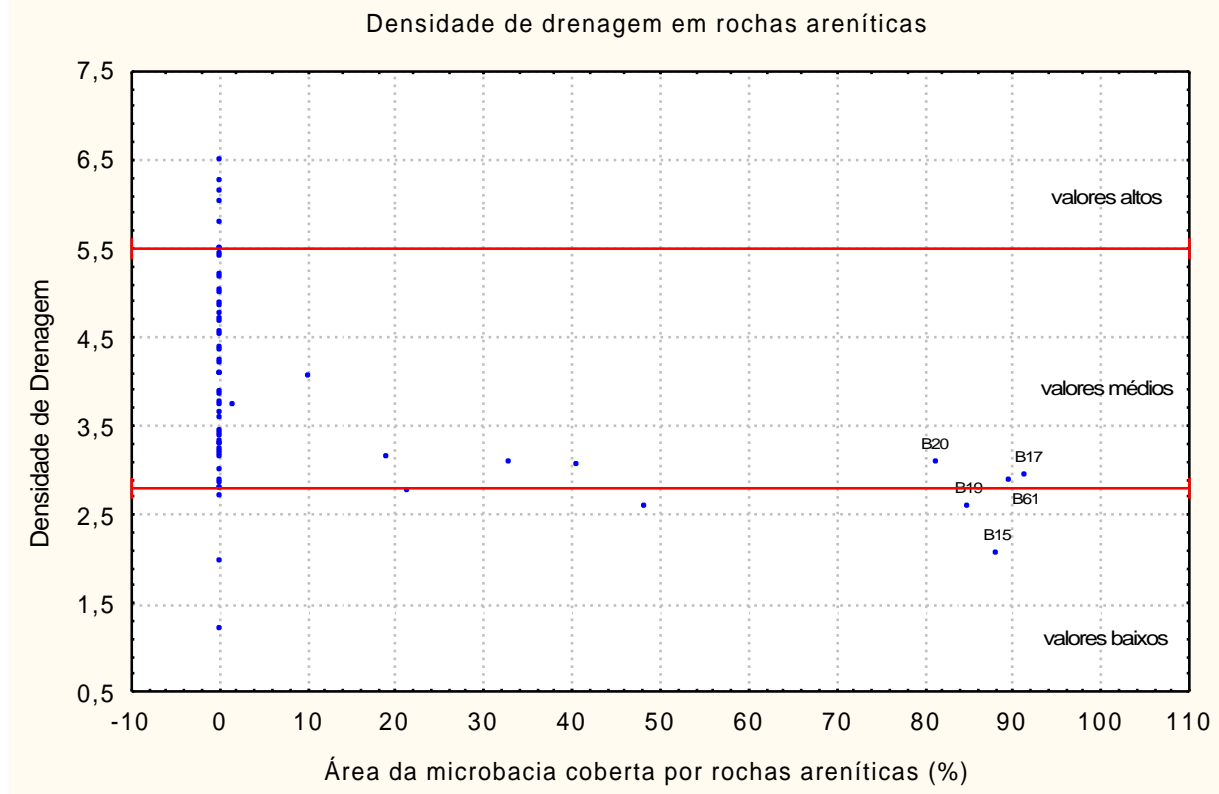

Figura 62: Relação entre microbacias areníticas e a densidade de drenagem. 


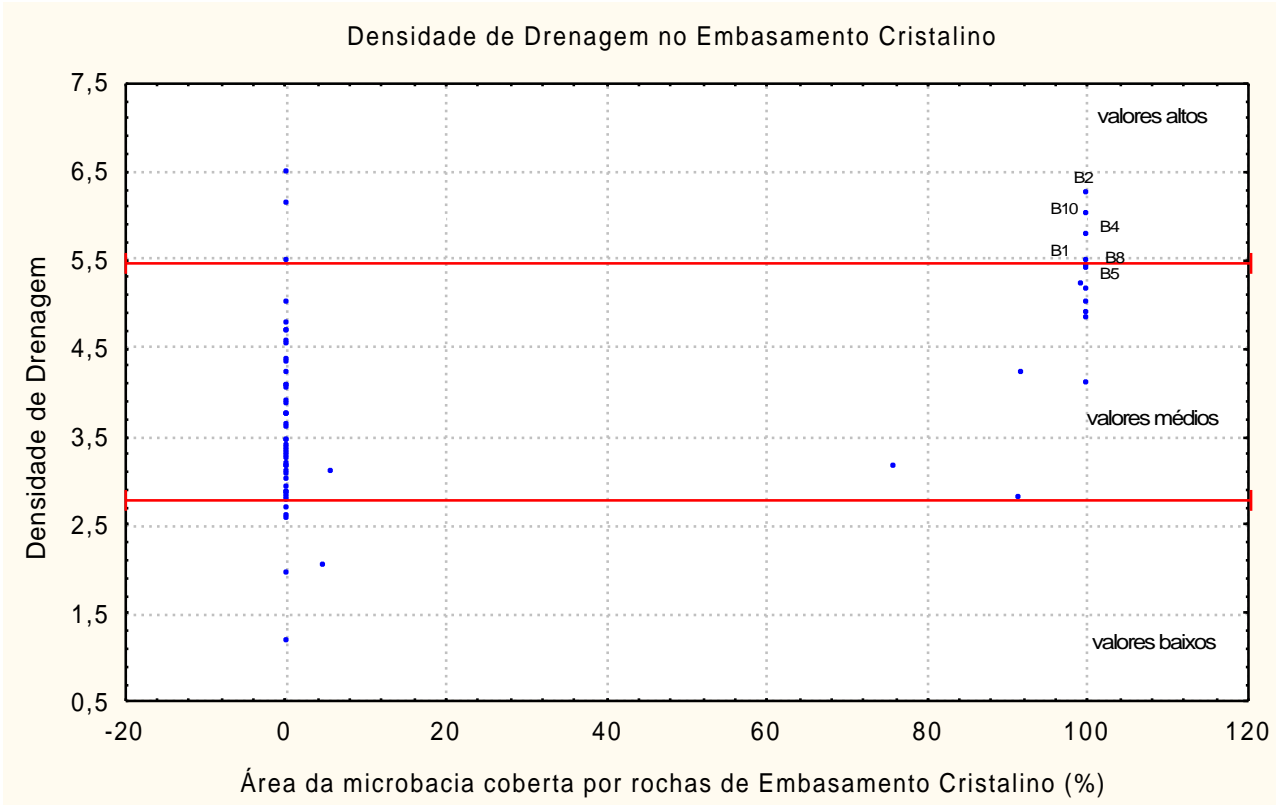

Figura 63: Relação entre microbacias do Embasamento e a densidade de drenagem.

Quanto à densidade Hidrográfica, os valores obtidos para as microbacias areníticas apresentam-se todos abaixo da média geral das microbacias (10,5 $\mathrm{N} / \mathrm{km}^{2}$ ), e duas delas encontram-se da faixa de valores baixos (B19 e B15), como pode ser observado na Figura 64.

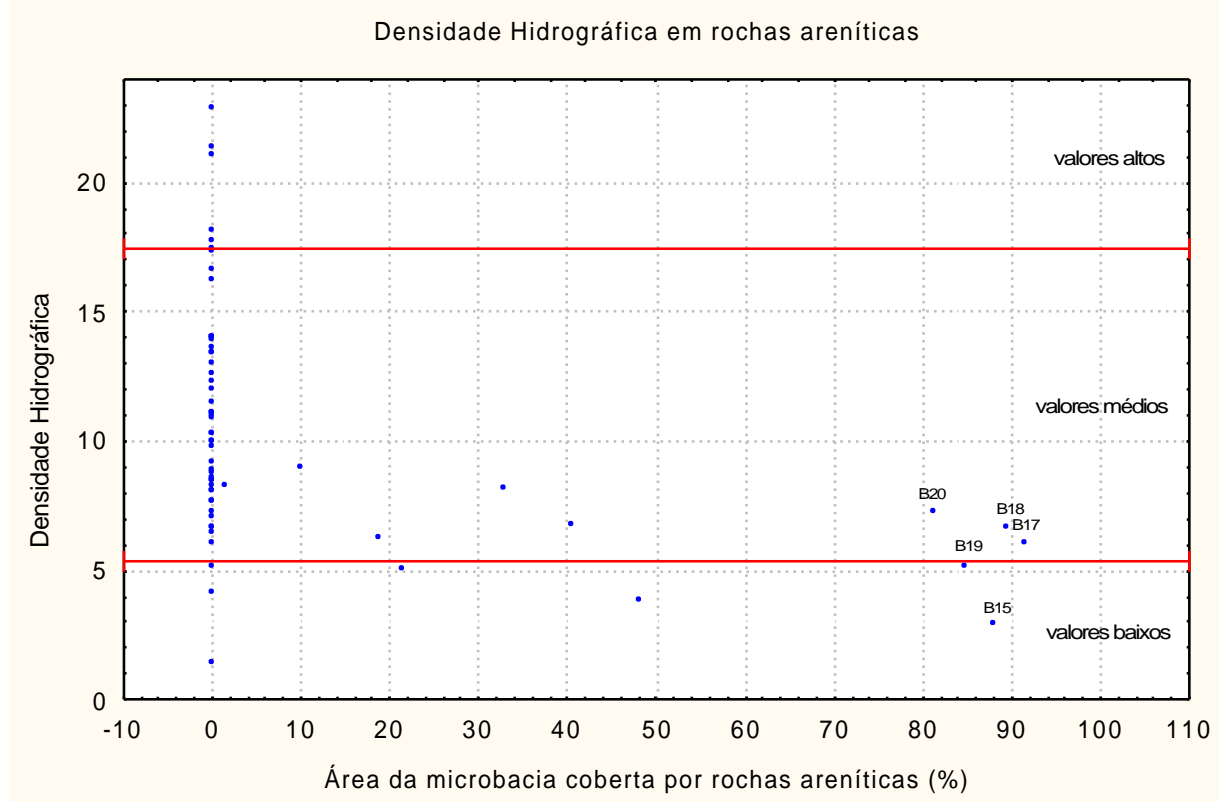

Figura 64: Relação entre microbacias areníticas e a densidade Hidrográfica. 
As microbacias do Embasamento possuem valores bem dispersos, variando de 5,2 a 21,5 (Figura 65). Entretanto, das seis microbacias da bacia do rio Capivari que possuem densidade Hidrográfica com valores altos, quatro apresentam rochas do Embasamento como substrato rochoso (B10, B8, B4, B2).

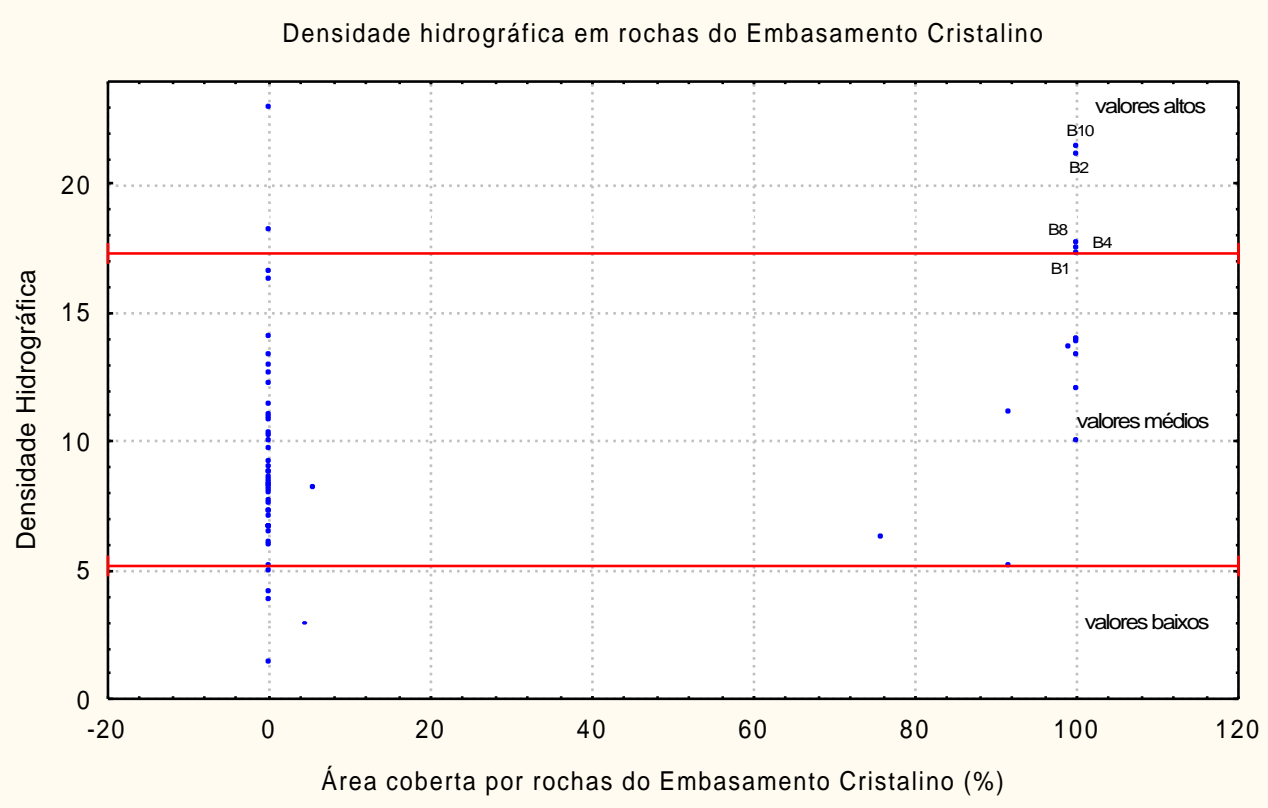

Figura 65: Relação entre microbacias do Embasamento e a densidade Hidrográfica.

Os resultados da razão de comprimento médio são dispersos tanto para as microbacias areníticas quanto para as de rochas sedimentares intercaladas e as de rochas do Embasamento Cristalino, como pode ser observado na matriz gráfica da Figura 61. Os resultados da razão de bifurcação são dispersos para as microbacias areníticas e do Embasamento.

Nas microbacias de rochas sedimentares intercaladas ocorre uma tendência de comportamento para a razão de bifurcação, como pode ser observada no gráfico da Figura 66. Os valores obtidos para as microbacias com mais de $80 \%$ de rochas sedimentares intercaladas variam entre 3,3 e 4,7. 


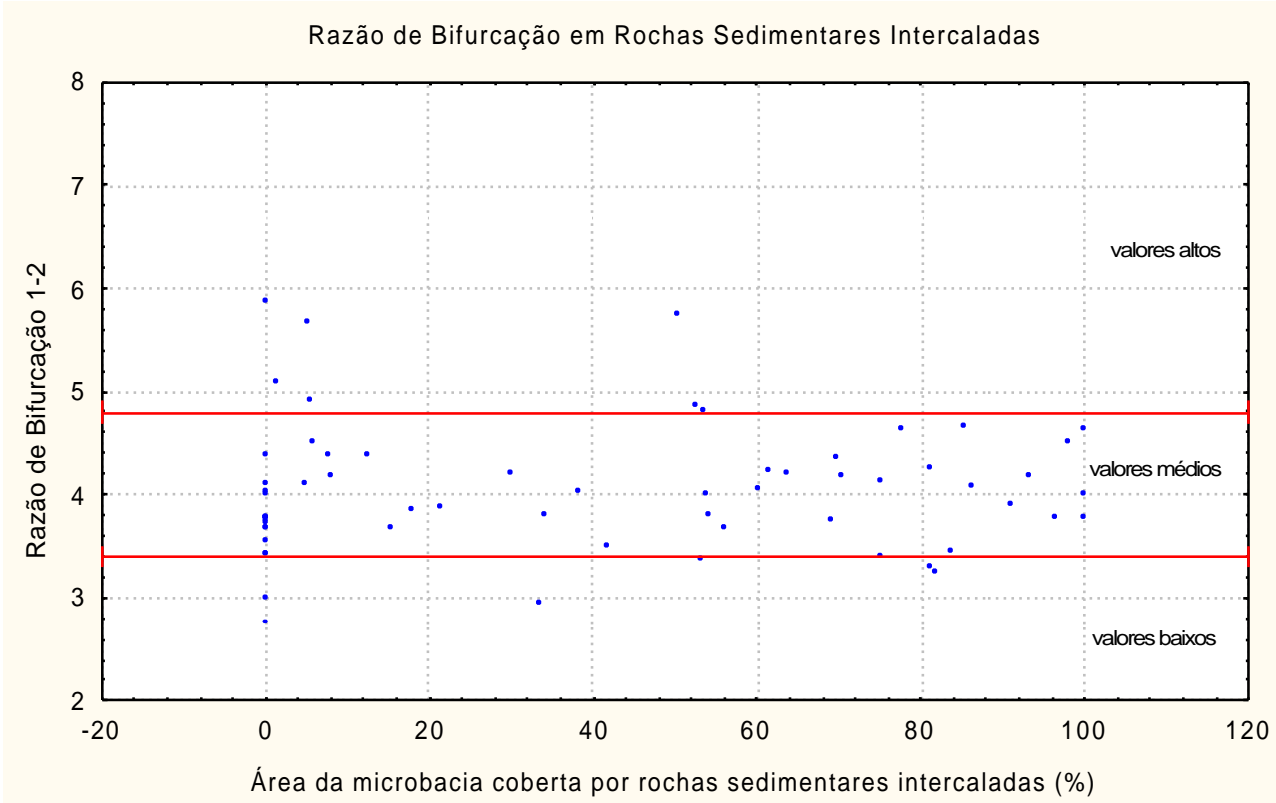

Figura 66: Relação entre microbacias do Embasamento e a razão de bifurcação.

\subsection{3 - Relação entre as variáveis da rede de drenagem e suas taxas de variação (\%) no período entre 1972 e 1995}

As taxas de variação descrevem, em porcentagem, as alterações ocorridas nas variáveis da rede de drenagem das microbacias entre 1972 para 1995. Uma taxa de variação positiva indica que houve um aumento no valor da variável neste período e, em contrapartida, uma taxa negativa indica que houve uma diminuição, ou seja, ocorreu uma perda com relação a variável analisada, do ano de 1972 para 1995. Vale ressaltar que taxas de variação pequenas (inferiores a 10\%), não foram consideradas nas análises, uma vez que nesta faixa podem estar embutidos erros de fotointerpretação, mensuração ou de processamento dos dados.

A matriz gráfica da Figura 67 permite uma visualização geral de possíveis tendências de comportamento entre as variáveis da rede de drenagem e suas taxas de variação, bem como tendências de comportamento entre taxas de variação de diferentes variáveis. 
Matriz gráfica - variáveis da rede de drenagem (1972) x taxas de variação

\begin{tabular}{|c|c|c|c|c|c|c|c|}
\hline 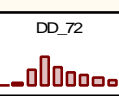 & म & ' & \% & ध & i: & ख: & \% \\
\hline 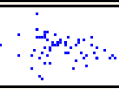 & 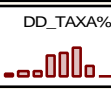 & $\therefore$ & $\because 3$ & '१': & : & $4 \%$ & 4 \\
\hline . & औ, & \begin{tabular}{|c|}
$\mathrm{DH}_{72}$ \\
$\mathrm{a}$
\end{tabular} & on & 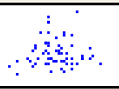 & 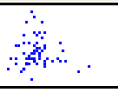 & $\therefore$ & $\begin{array}{c}\vdots \\
\vdots \\
4\end{array}$ \\
\hline in & int: & $\therefore$ & $\begin{array}{c}\text { DH_TAXA\% } \\
\text { _oDllaO-. }\end{array}$ & $\because$ & 3 & : & 8 \\
\hline 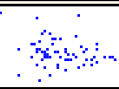 & \% & 3 & & 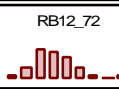 & $\Leftrightarrow$ & ' & 4 \\
\hline ब1 & 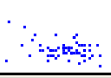 & He & 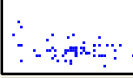 & Mu & al] & m & 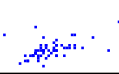 \\
\hline मा & 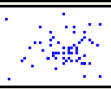 & 8 & 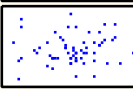 & m & 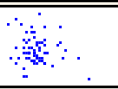 & 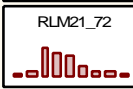 & 3 \\
\hline मे & ओ & ४ & 4 & 4 & i & $\because \forall$ & 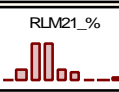 \\
\hline
\end{tabular}

Figura 67: Matriz gráfica com variáveis da rede de drenagem e taxas de variação das variáveis morfométricas no período entre 1972 e 1995.

$\mathrm{Na}$ análise da densidade de drenagem e da densidade hidrográfica em relação às suas taxas de variação, observa-se que as alterações tendem a ser maiores quando estas variáveis apresentam valores mais baixos. O gráfico da Figura 68 mostra como a dispersão nas taxas de variação é maior para valores de densidade de drenagem mais baixos que a média $\left(3,8 \mathrm{~km} / \mathrm{km}^{2}\right)$. Das quatro microbacias que apresentam perdas superiores a 20\% (B44, B24, B22 e B17), apenas na B44 a densidade de drenagem está acima da média.

Esta tendência é ainda mais pronunciada na análise da densidade hidrográfica, como pode ser observado no gráfico da Figura 69. Das seis microbacias que apresentam perdas maiores que 40\%, cinco (B24, B22, B20, B18 e $\mathrm{B} 17)$ apresentam densidade hidrográfica mais baixa que a média $\left(10,5 \mathrm{~N} / \mathrm{km}^{2}\right)$. A exceção é também a microbacia B44 que apresenta uma densidade Hidrográfica superior a $15 \mathrm{~N} / \mathrm{km}^{2}$. 


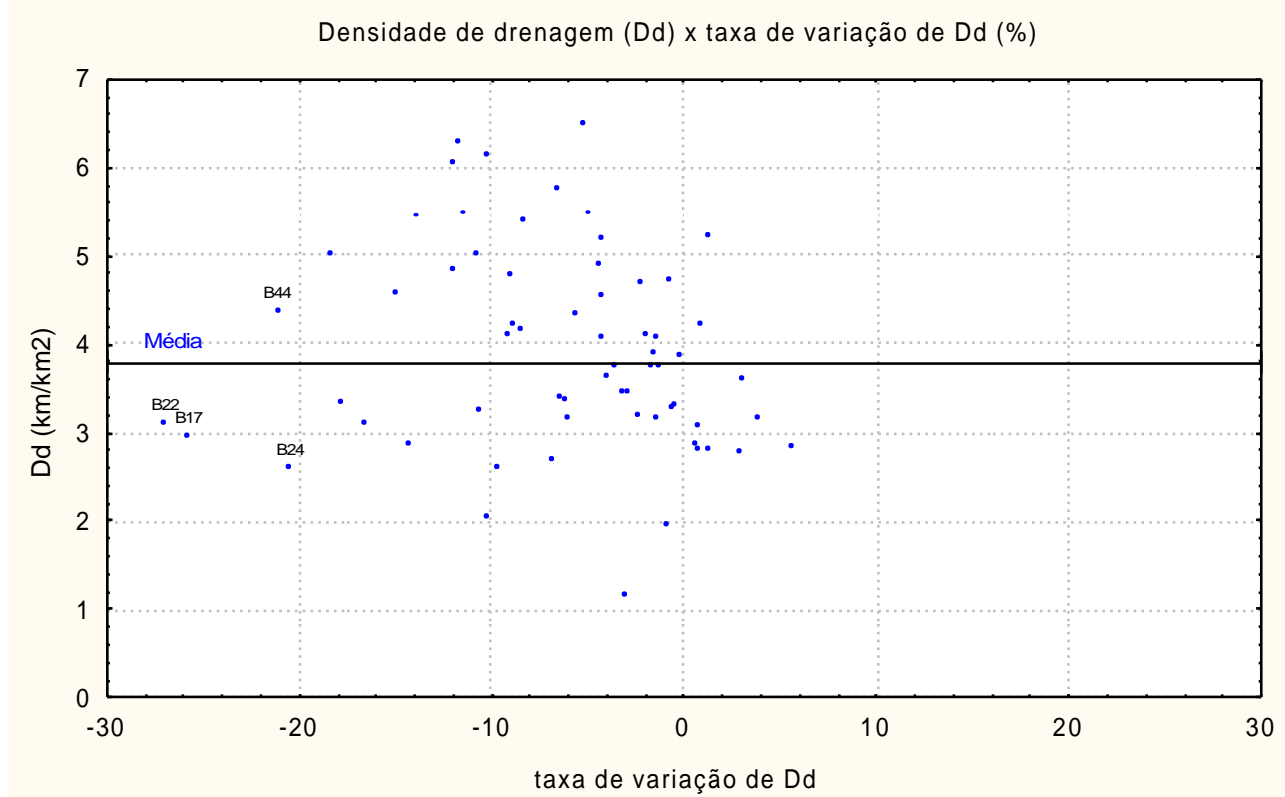

Figura 68: Relação entre densidade de drenagem e sua taxa de variação (\%) no período entre 1972 e 1995.

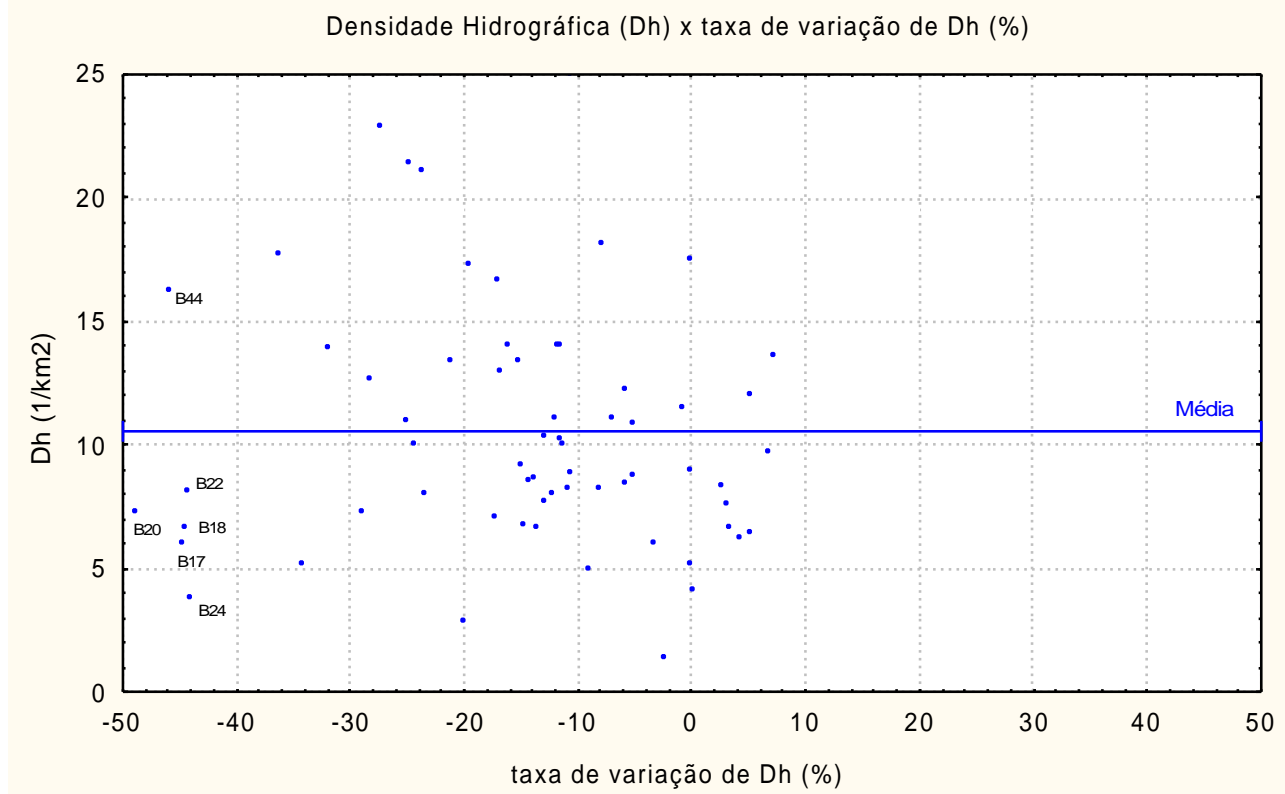

Figura 69: Relação entre densidade Hidrográfica e sua taxa de variação (\%) no período entre 1972 e 1995. 
O gráfico da Figura 70 relaciona as taxas de variação da densidade de drenagem e da densidade hidrográfica. A relação linear existente entre as duas taxas permite delimitar dois grupos de microbacias onde ocorrem perdas pronunciadas, e são descritas como grupo de alterações altamente significativas e de alterações significativas. As microbacias inseridas no grupo de alterações altamente significativas são: B51, B44, B26, B24, B22, B20, B18, B19, B17, B8 e B3. E as do grupo alterações significativas são: B58, B56, B40, B15, B12, B10, B11, B2 e B1. As microbacias que fazem parte destes dois grupos correspondem ao grupo de microbacias com alterações significativas, definido pela análise de agrupamento (descrito no Capítulo 5).

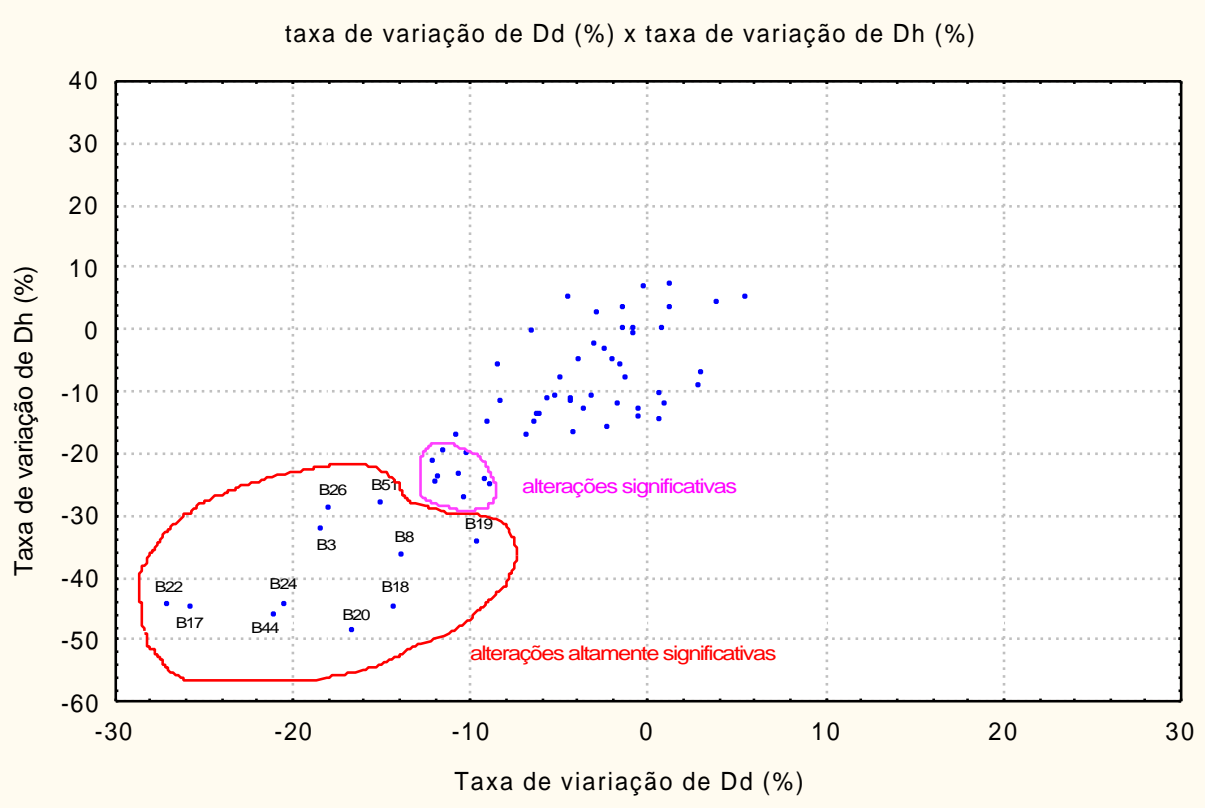

Figura 70: Relação entre taxas de variação (\%) de densidade de drenagem e densidade Hidrográfica, no período entre 1972 e 1995.

$\mathrm{Na}$ análise das alterações ocorridas nas razões de bifurcação e de comprimento médio observa-se uma alta dependência com as dimensões e o grau hierárquico das microbacias, como ilustra os gráficos das Figuras 71 e 72 . As alterações em Rb1-2 só são significativas em microbacias com áreas inferiores a $20 \mathrm{~km}^{2}$ (Figura 71) e/ou para as microbacias de $3^{\text {a }}$ ou $4^{2}$ ordem hierárquica de canais (Figura 72). O mesmo tipo de comportamento ocorre para a variável razão de comprimento médio (Rlm2-1). 
Taxa de variação da Razão de Bifurcação (Rb1-2) x área da microbacia

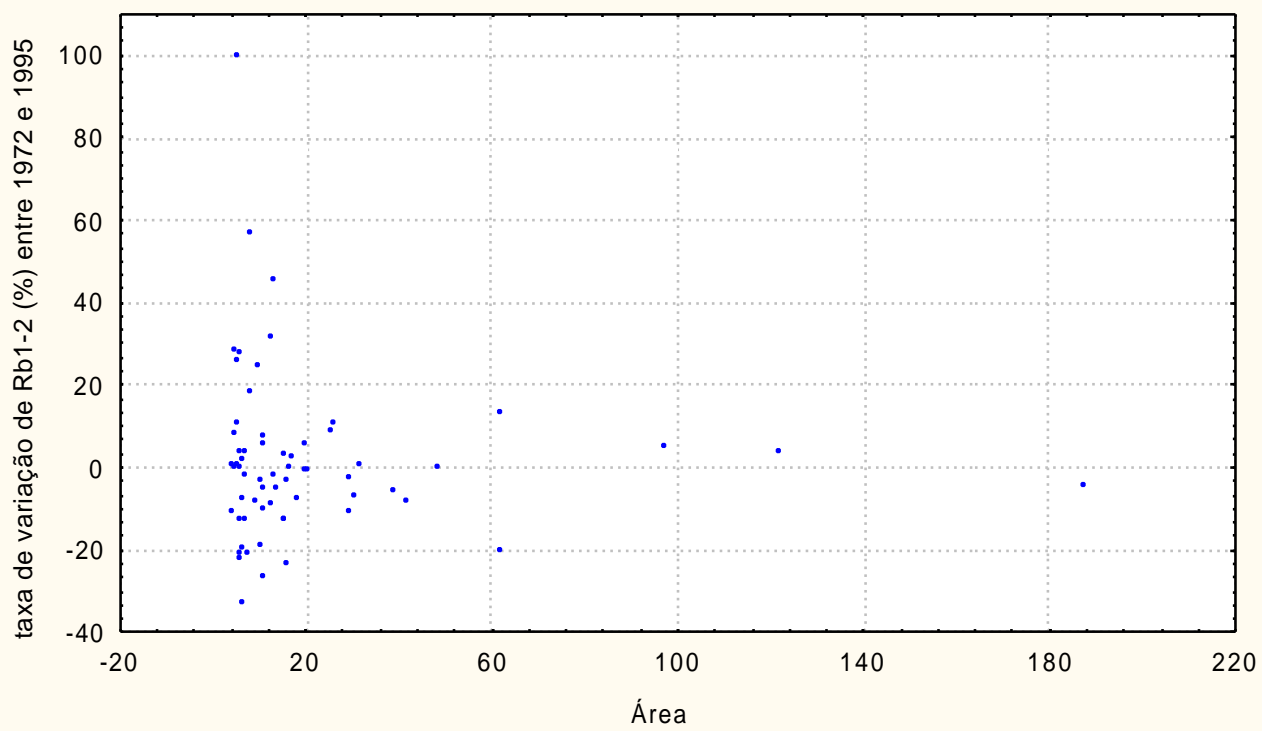

Figura 71: Relação entre área da microbacia e taxa de variação de Rb1-2 (\%) no período entre 1972 e 1995.

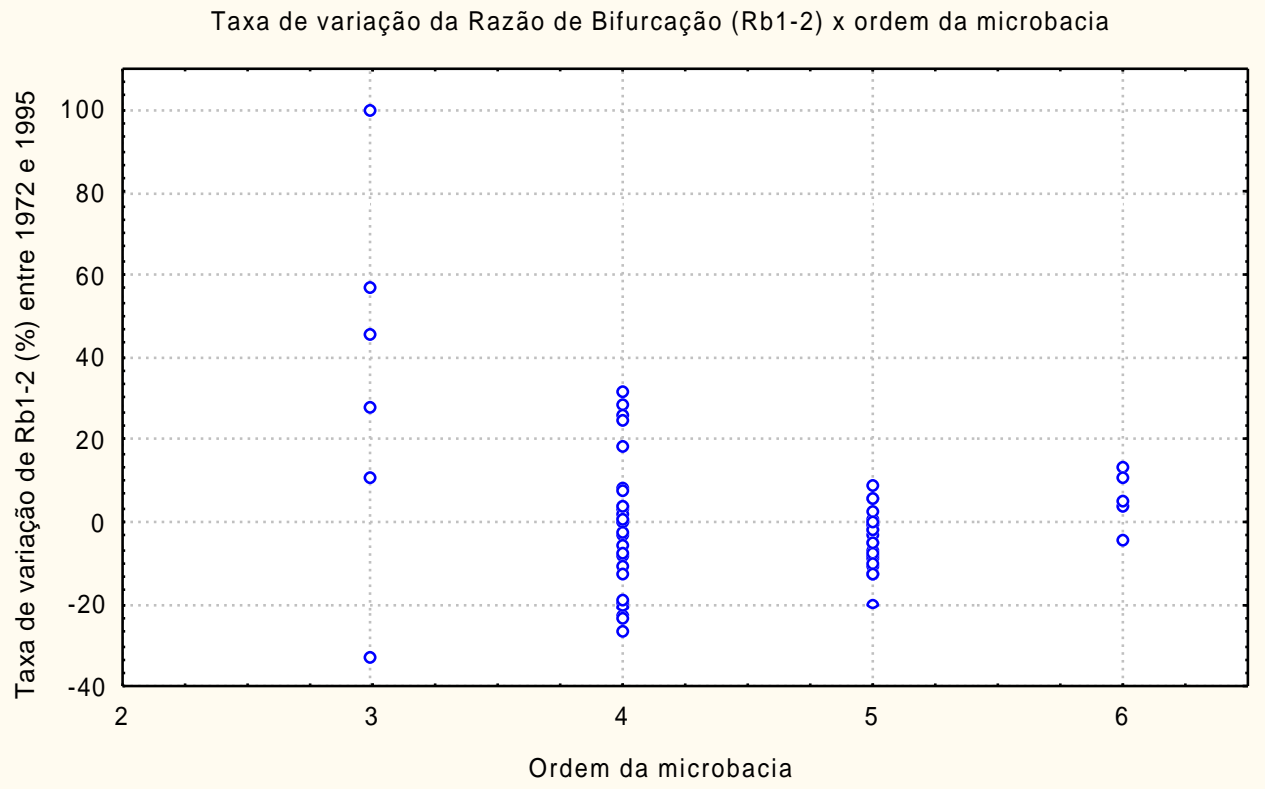

Figura 72: Relação entre ordem da microbacia e taxa de variação de Rb1-2 (\%) no período entre 1972 e 1995.

Os gráficos das Figuras 73 e 74, que indicam as relações entre a taxa de variação da razão de bifurcação e as densidades de drenagem e hidrográfica, 
mostram que as taxas de variação tendem a ser maiores para microbacias com Dd e Dh menores, ou seja, há uma dependência da taxa de variação com a quantidade e comprimento dos canais antes das alterações. Esta mesma tendência é observada para a taxa de variação da razão de comprimento médio.

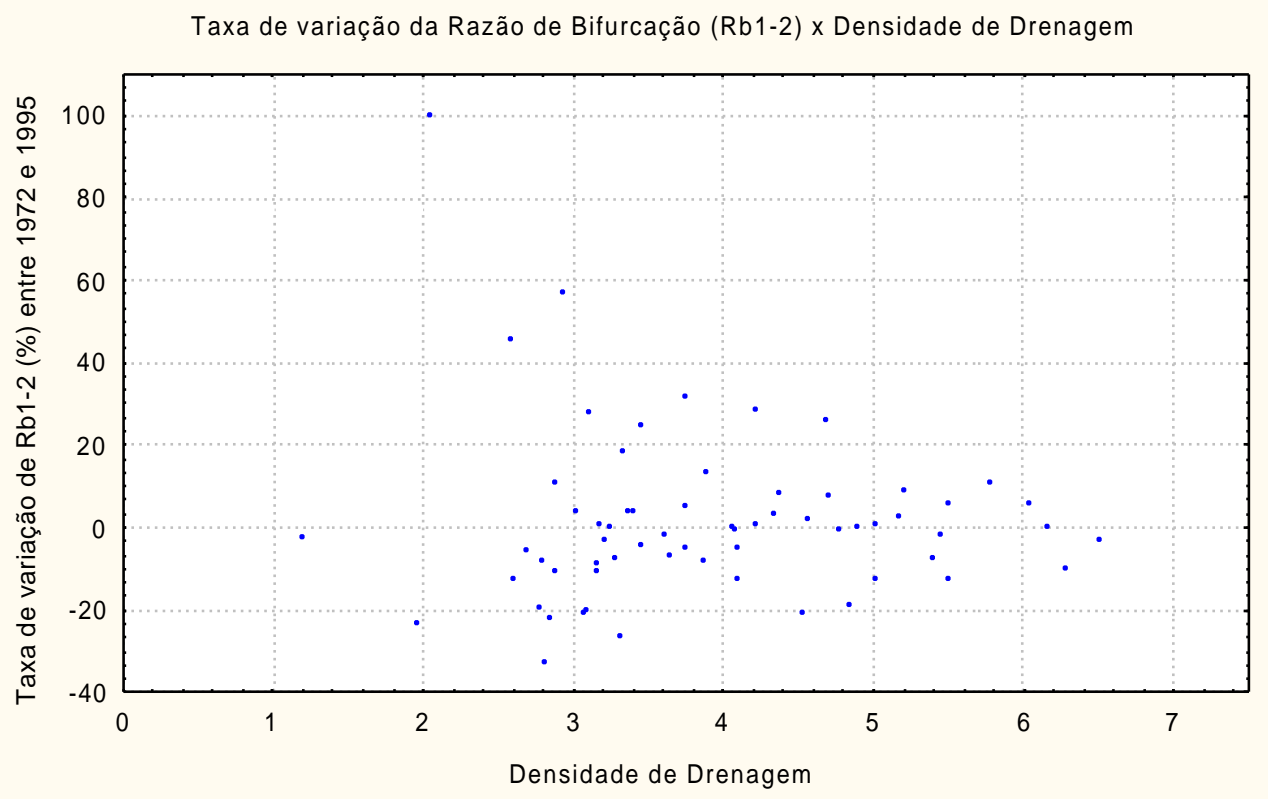

Figura 73: Relação entre densidade de drenagem e taxa de variação de Rb1-2 (\%) no período entre 1972 e 1995.

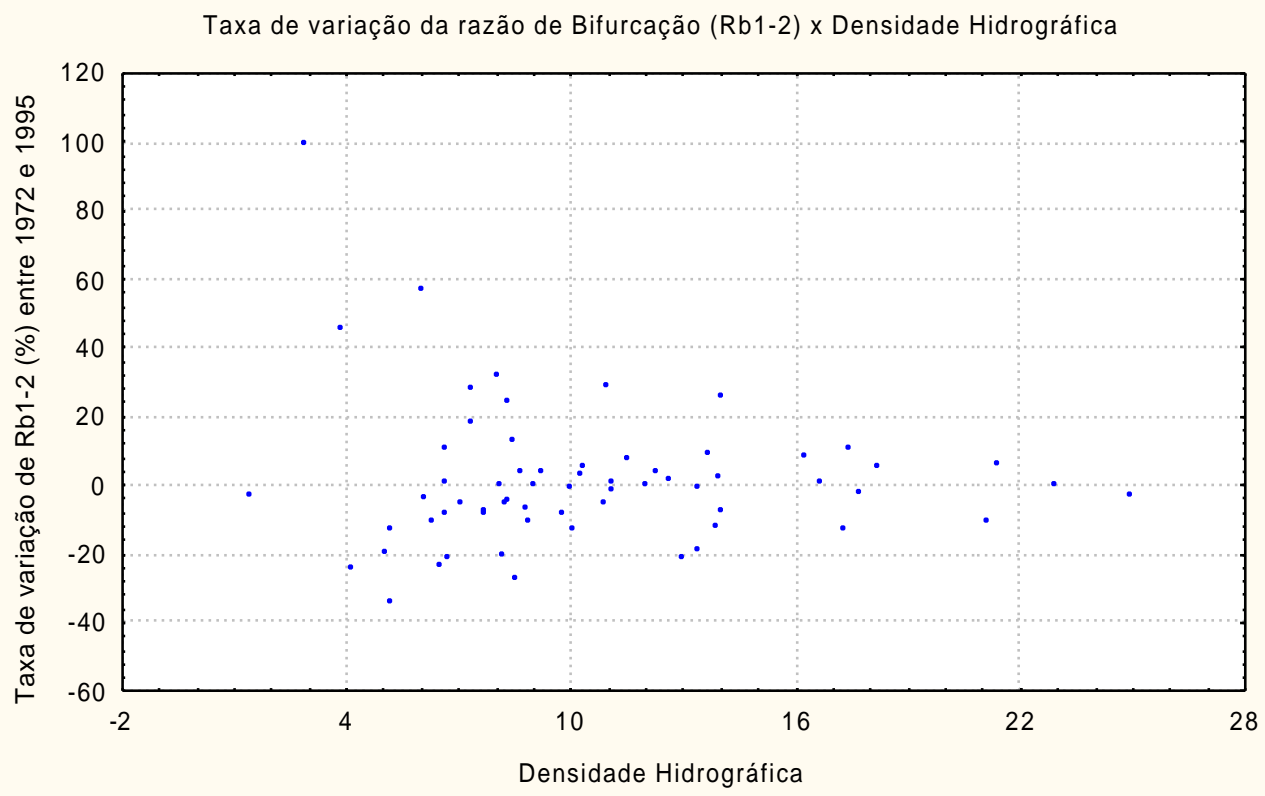

Figura 74: Relação entre densidade hidrográfica e taxa de variação de Rb1-2 (\%) no período entre 1972 e 1995. 
A relação entre as taxas de variação das razões de bifurcação e de comprimento médio apresentada no gráfico da Figura 75 tendem a uma relação linear. Alterações negativas em Rb1-2, geralmente conduzem a alterações também negativas em RIm2-1 (Ex: B55, B48, B21 e B13); e da mesma forma, quando ocorrem alterações positivas (Ex: B62, B32, B20, B17). Entretanto, as microbacias B42, B40, B24 e B15 não obedecem a este comportamento, uma vez que alterações negativas em Rb1-2, conduziram a alterações positivas em RIm2-1.

taxa de variação de Rb1-2 (\%) x taxa de variação de RIm2-1 (\%)

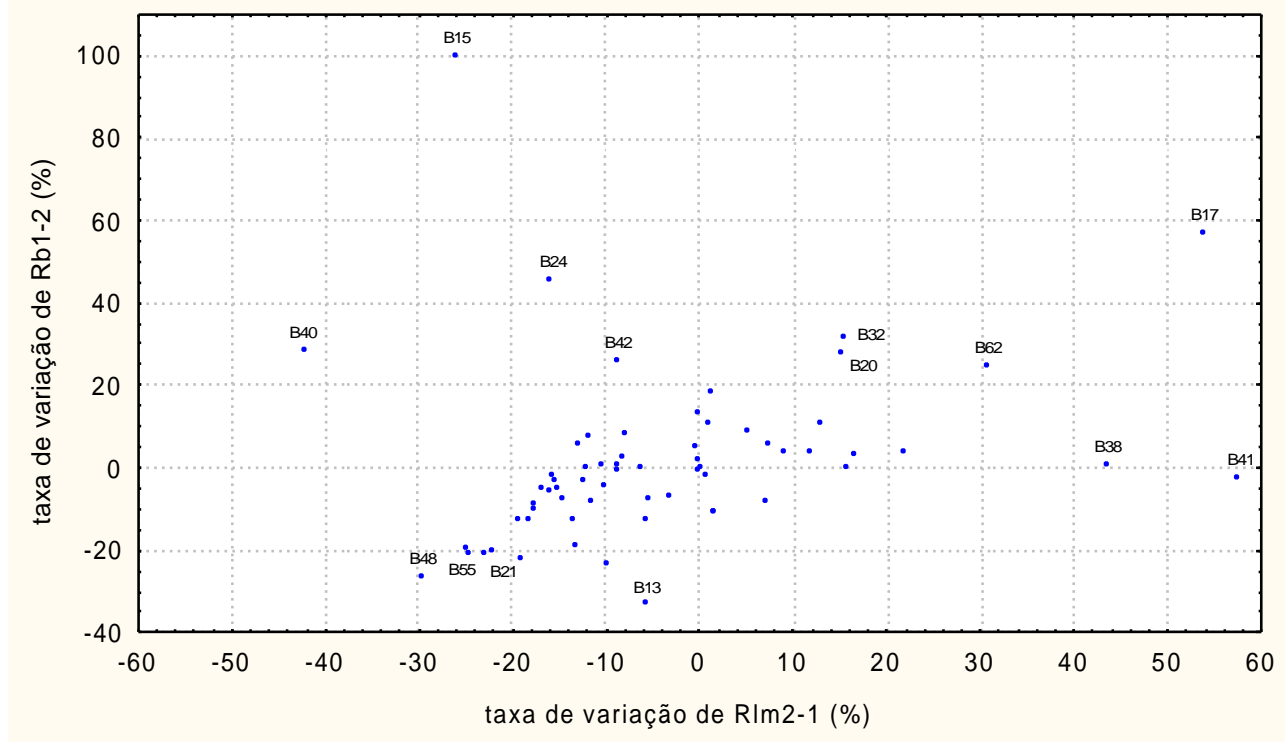

Figura 75: Relação entre taxas de variação (\%) de razão de bifurcação e razão de comprimento médio, no período entre 1972 e 1995.

\subsection{4 - Relações entre taxas de variação de variáveis da rede de drenagem e características de uso e ocupação}

A análise das relações existentes entre as alterações ocorridas nas variáveis da rede de drenagem, no período entre 1972 e 1995, e o tipo de uso e ocupação predominante foi efetuada considerando-se aquelas microbacias onde ocorrem o nítido predomínio de uma das classes de uso e ocupação. Assim, considerou-se como microbacias urbanas aquelas onde mais de $60 \%$ da área é ocupada pelas 
classes urbanas altamente ou mediamente adensadas; como microbacias rurais, com predomínio de pastagem, aquelas onde mais de $70 \%$ da área é ocupada pela classe pastagem e microbacias rurais, com predomínio de cana de açúcar, aquelas onde mais de $70 \%$ da área é ocupada pela classe cana de açúcar.

As cinco microbacias urbanas (B22, B20, B18, B17 e B15), que estão assinaladas no gráfico da Figura 76 por pontos vermelhos, apresentam perdas superiores a $10 \%$ na densidade de drenagem. Considerando-se todas as 64 microbacias da bacia do Capivari, apenas quatro apresentam perdas superiores a $20 \%$ e destas, duas são microbacias urbanas (B22 e B17).

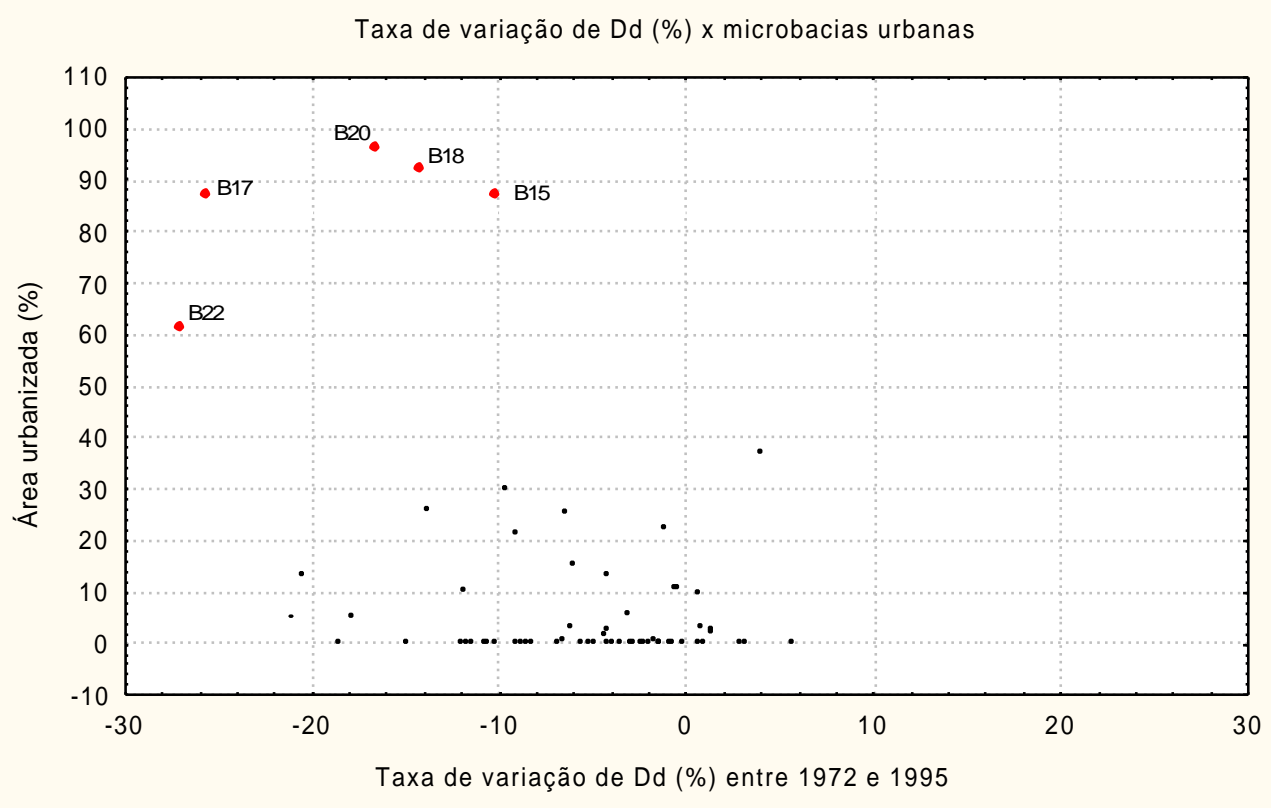

Figura 76: Relação entre microbacias urbanas e taxa de variação de Dd (\%) no período entre 1972 e 1995.

Quanto à densidade Hidrográfica, todas as microbacias urbanas apresentam perdas superiores a $20 \%$ (Figura 77 ). Considerando-se o conjunto com todas as microbacias do rio Capivari, das seis que apresentam perdas superiores a $40 \%$, quatro são microbacias urbanas (B22, B20, B18 e B17). 


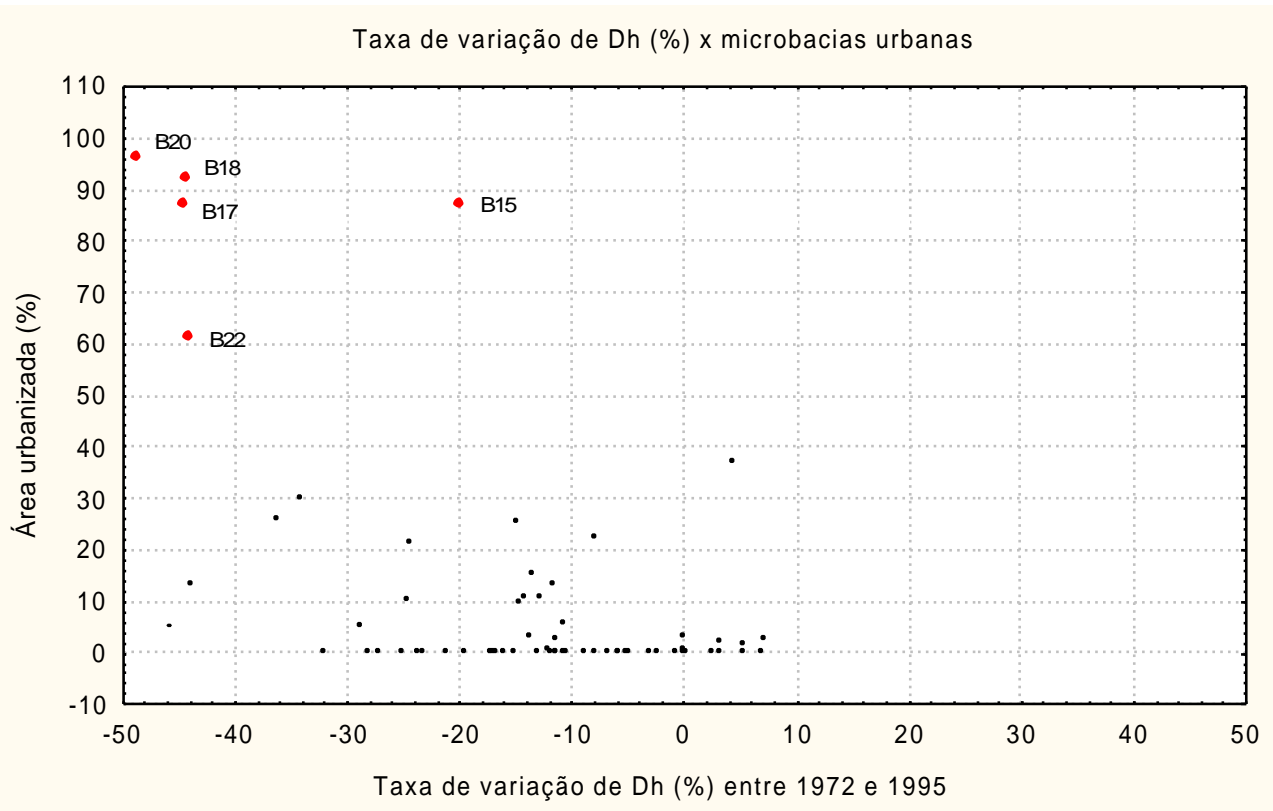

Figura 77: Relação entre microbacias urbanas e taxa de variação de Dh (\%) no período entre 1972 e 1995.

As microbacias rurais, com predomínio de pastagem, não apresentam alterações muito significativas quanto à densidade de drenagem (Figura 78). As cinco microbacias com grande predomínio da classe pastagem (>70\%), assinaladas com pontos vermelhos, apresentam perdas inferiores a $10 \%$ e das vinte e nove com mais de $50 \%$ da área coberta pela classe pastagem, apenas duas apresentam alterações superiores a 15\%. As exceções são as microbacias B26 e B24 que apresentam perdas de 18\% e 21\%, respectivamente.

Quanto à densidade hidrográfica, as perdas para as cinco microbacias com grande predomínio de pastagem são inferiores a 15\% (Figura 79). Considerando-se as vinte e nove microbacias com mais de $50 \%$ da área ocupada pela classe pastagem, sete apresentam perdas superiores a $20 \%$ e apenas duas superiores a $30 \%$ (B24 e 19).

Para as doze microbacias rurais com grande predomínio de cana de açúcar (>70\%), assinaladas no gráfico da Figura 80 com pontos vermelhos, as alterações na densidade de drenagem são inferiores a 15\% e destas apenas a microbacia B51 apresenta perda superior a 10\%. Considerando-se as vinte e uma microbacias onde 
mais de $50 \%$ da área é coberta por cana de açúcar, apenas duas apresentam alterações realmente significativas (B44 e B51).

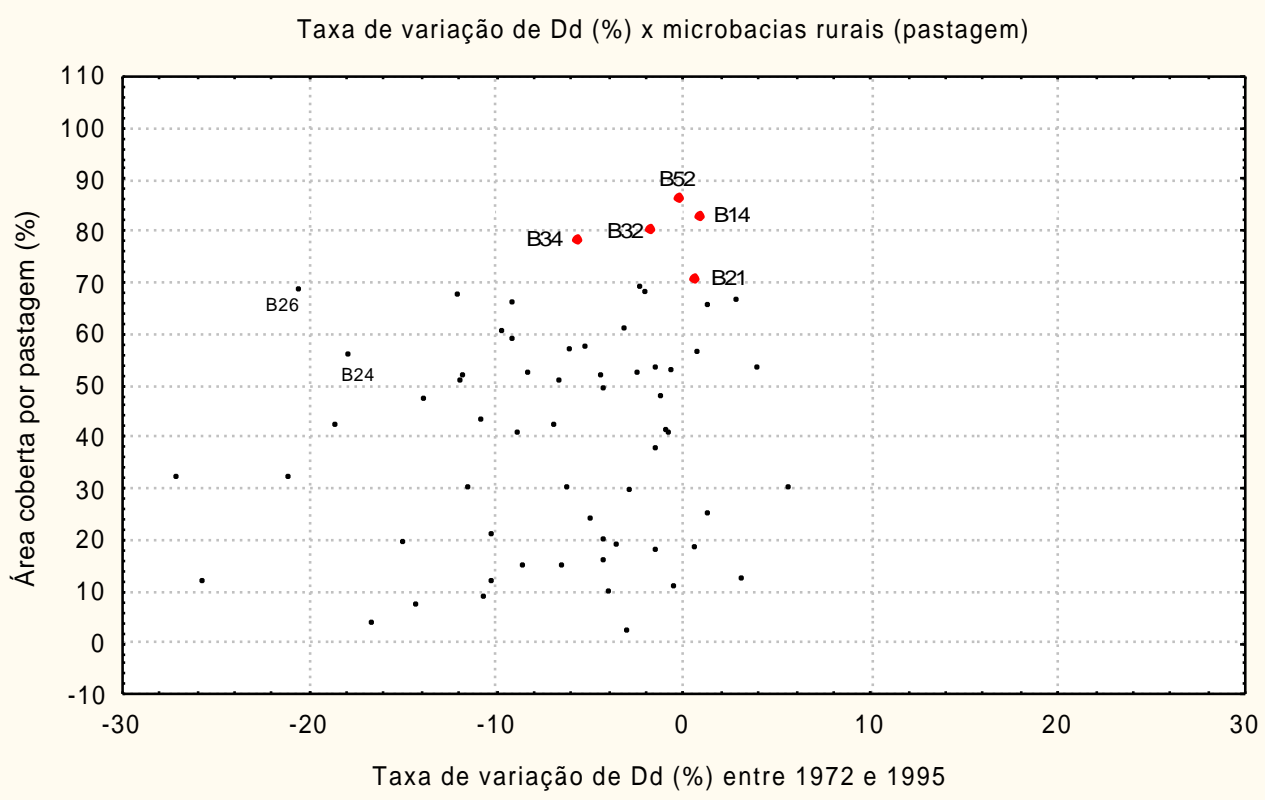

Figura 78: Relação entre microbacias rurais (com predomínio de pastagem) e taxa de variação de Dd (\%) no período entre 1972 e 1995.

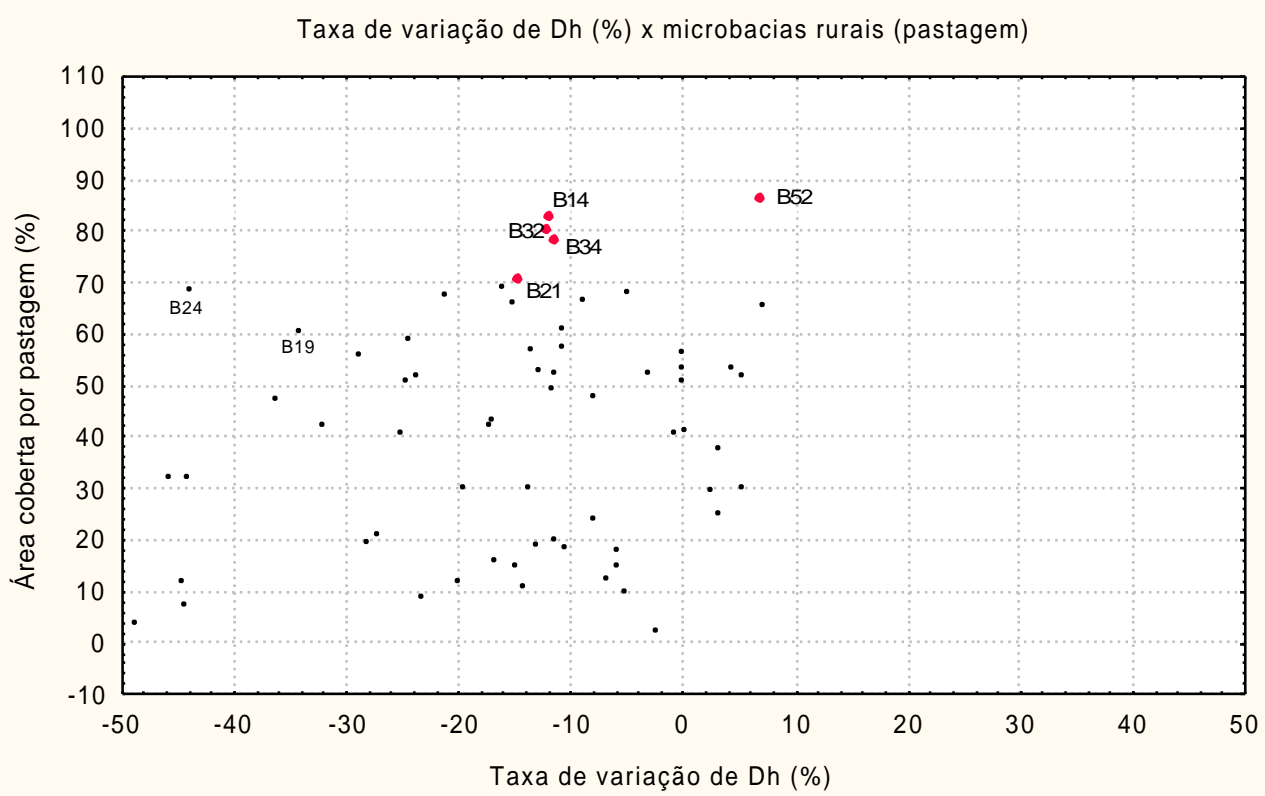

Figura 79: Relação entre microbacias rurais (com predomínio de pastagem) e taxa de variação de Dh (\%) no período entre 1972 e 1995. 


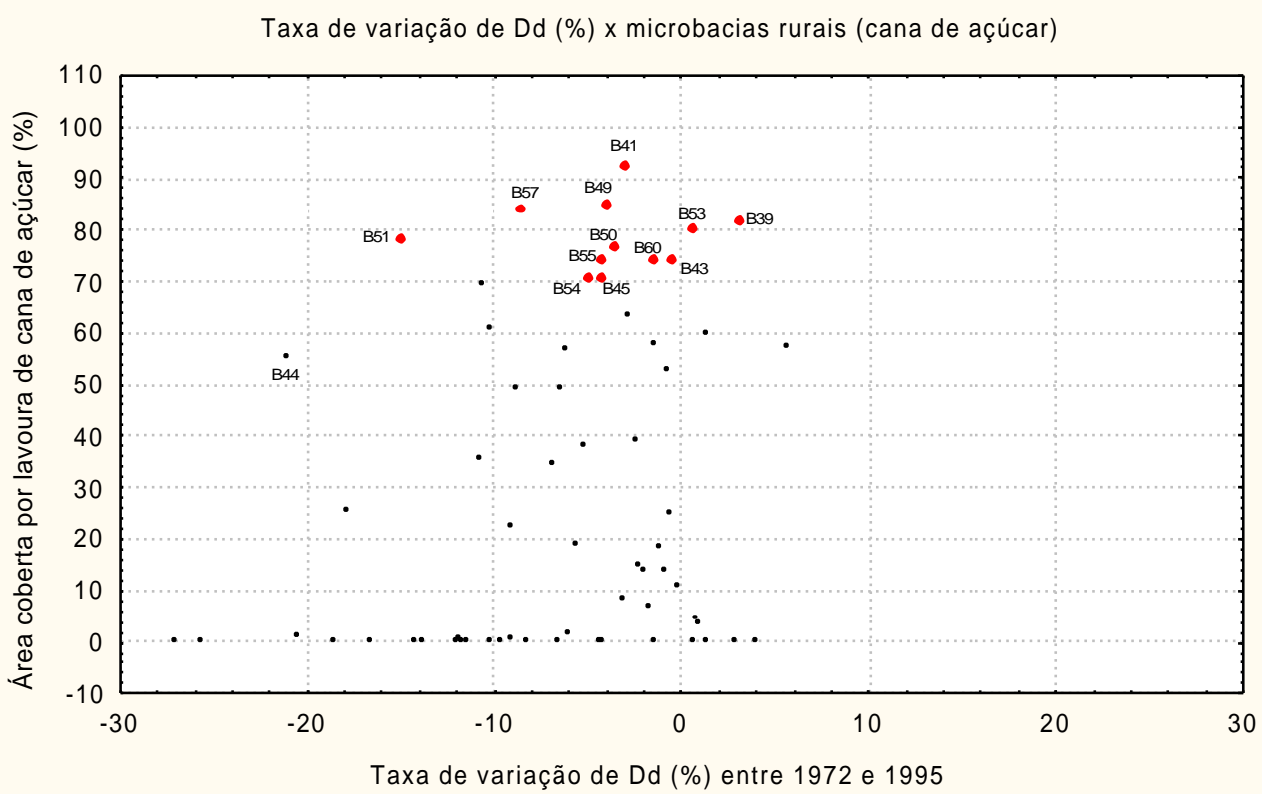

Figura 80: Relação entre microbacias rurais (com predomínio de cana de açúcar) e taxa de variação de Dd (\%) no período entre 1972 e 1995.

Quanto à densidade hidrográfica, as perdas são inferiores a $20 \%$ para onze das doze microbacias com maior predomínio de cana de açúcar (Figura 81). Considerando-se as vinte e uma com mais de $50 \%$ de cana, três apresentam alterações superiores a 20\% e apenas uma alterações superiores a $30 \%$ (B12).

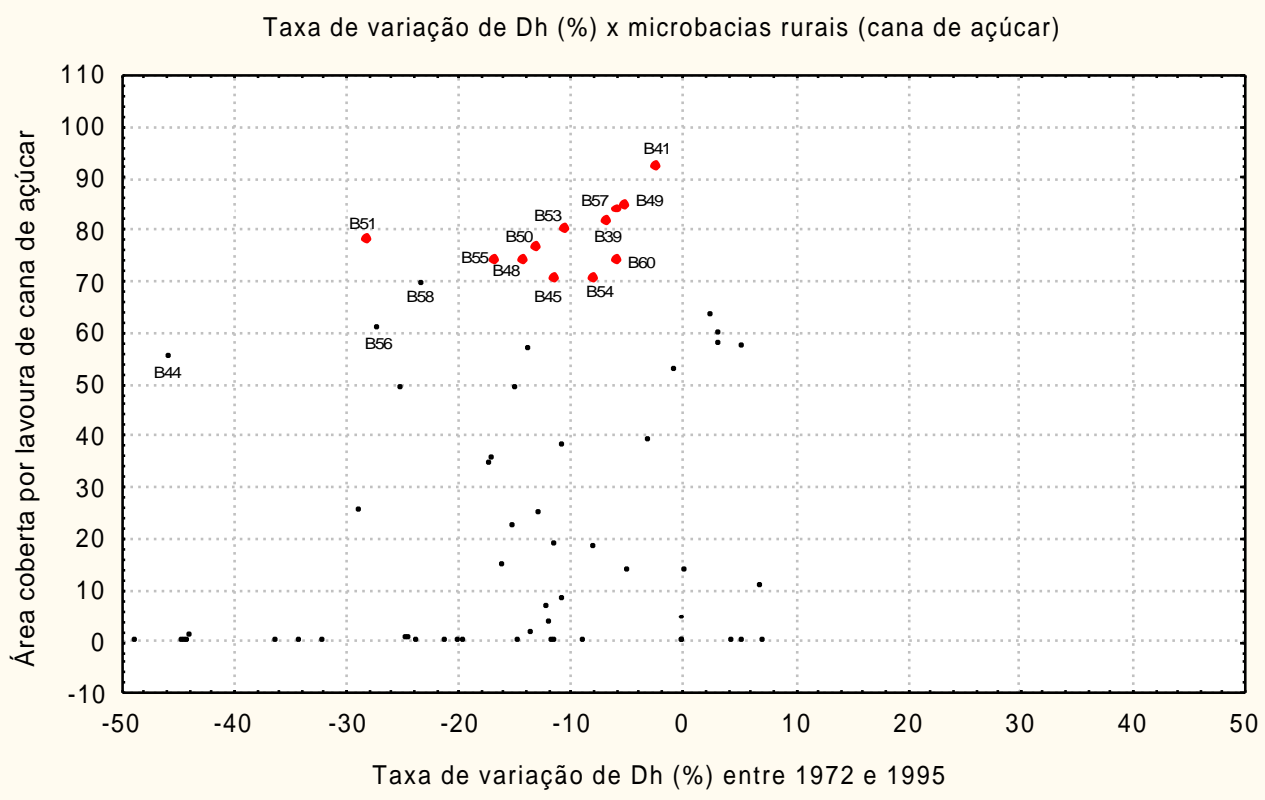

Figura 81: Relação entre microbacias rurais (com predomínio de cana de açúcar) e taxa de variação de Dh (\%) no período entre 1972 e 1995. 


\subsection{5 - Influência das variáveis da rede de drenagem na avaliação das alterações das microbacias}

$\mathrm{Na}$ avaliação das alterações ocorridas na composição da rede de drenagem das microbacias, provocadas pelas mudanças ocorridas nas variáveis da rede de drenagem, foi necessário, inicialmente, compreender as relações existentes entre estas variáveis e destas com as suas taxas de variação, no período entre 1972 e 1995. Posteriormente, foi avaliada a influência do substrato rochoso e características de uso e ocupação nas alterações.

A relação de dependência existente entre algumas das variáveis, apesar de cada uma descrever uma propriedade específica da bacia hidrográfica, faz com que suas taxas de variação apresentem resultados similares. Neste contexto, efetuouse uma análise mais aprofundada em apenas duas destas variáveis, a densidade de drenagem (Dd) e a densidade hidrográfica (Dh). Alterações nas variáveis razão de bifurcação e razão de comprimento médio foram utilizadas em complementação a esta análise.

Apesar de serem derivadas, respectivamente, de um parâmetro dimensional e outro adimensional, a densidade de drenagem e a densidade hidrográfica apresentaram um alto grau de correlação, indicando que o desaparecimento de canais de primeira ordem tende a interferir na dinâmica das águas, pela diminuição, na mesma proporção, da sua capacidade de escoamento linear.

Com relação à influência das dimensões das microbacias no valor da densidade de drenagem, não foi observada a tendência típica de comportamento, conforme descrita por Horton (1945) e Christofolleti (1979), de que bacias de menor porte e de grau hierárquico mais elevado tendem a apresentar valores mais elevados. Foram encontrados valores no intervalo de 1,2 a $6,5 \mathrm{~km} / \mathrm{km}^{2}$ para microbacias de tamanhos e hierarquias diferentes. As seis maiores microbacias apresentaram valores considerados médios, variando de 3,0 a 4,0 km/km².

Não foi observada, também, uma interferência direta das variáveis morfológicas nos valores de densidade de drenagem e densidade hidrográfica. A incipiente tendência de crescimento linear da densidade de drenagem com a 
relação de relevo, mostrada no gráfico da Figura 59, parece estar mais ligada à dependência recíproca destas variáveis com fatores geológicos e geomorfológicos.

A composição do substrato rochoso mostrou-se influente tanto na densidade de drenagem quanto na densidade hidrográfica. A densidade de drenagem das microbacias areníticas não ultrapassou $3,4 \mathrm{~km} / \mathrm{km}^{2}$, enquanto nas microbacias com substrato granito-gnáissico do Embasamento Cristalino predominaram valores bem mais elevados, chegando a $6,4 \mathrm{~km} / \mathrm{km}^{2}$. Comportamento semelhante ocorreu com a densidade hidrográfica, que nas microbacias areníticas apresentou valores inferiores a $8,0 \mathrm{~N} / \mathrm{km}^{2}$, enquanto nas microbacias do Embasamento os valores chegaram a ultrapassar $20 \mathrm{~N} / \mathrm{km}^{2}$.

$\mathrm{Na}$ análise das alterações temporais, as taxas de variação mostraram-se influenciadas pelos valores ocorrentes antes das alterações. As maiores alterações (mais de $20 \%$ para Dd e mais de $40 \%$ para $\mathrm{Dh}$ ) tenderam a ocorrer em microbacias que apresentavam valores mais baixos de densidade de drenagem e hidrográfica, em 1972. Entretanto, algumas microbacias apresentaram perdas significativas (entre 10 e 20\% para Dd e entre 20 e 40\% para Dh) mesmo com Dd e Dh originalmente altos.

A influência de características de uso e ocupação nas alterações ocorridas na composição da rede de drenagem pôde ser constatada analisando-se microbacias com predomínio de uma determinada classe de uso e ocupação. Todas as microbacias tipicamente urbanas apresentaram perdas superiores a $10 \%$ em Dd e superior a $20 \%$ em Dh. A remobilização do solo, a impermeabilização de terrenos e a canalização de drenagens reduziram consideravelmente o número de canais primários, fato este que se refletiu na dinâmica de escoamento das águas nestas microbacias, favorecendo tanto o escoamento superficial como a diminuição da capacidade de infiltração das águas.

Nas microbacias rurais, com predomínio de pastagens e/ou cana de açúcar, as alterações foram menos pronunciadas. Das dezessete microbacias com mais de $70 \%$ de pastagem ou cana, dezesseis não apresentaram alterações significativas em Dd e Dh. A exceção foi detectada na microbacia B51 que apresentou alterações em torno de $15 \%$ em Dd e $30 \%$ em Dh. 
Alterações significativas foram detectadas em microbacias mistas. Das onze microbacias onde ocorreram as alterações mais significativas, seis são microbacias que não mostram predomínio de uma única classe de uso e ocupação. Todas estas microbacias, entretanto, estão em processo de expansão urbana, onde parte da área já está ocupada pelas classes urbanas mediamente adensada e/ou pouco adensada.

As taxas de variação das razões de bifurcação e de comprimento médio, são variáveis que podem indicar alterações nas interações entre canais de diferentes ordens hierárquicas sem que, necessariamente, tenha havido mudanças significativas na quantidade de rios ou no comprimento total de canais. Algumas microbacias, apesar de não apresentarem alterações em Dd e Dh, como por exemplo, B48, B55 e B21, apresentam alterações significativas nas razões de bifurcação e de comprimento médio.

As taxas de variação das variáveis Rb1-2 e Rlm2-1, contudo, devem ser incorporadas com cautela nas avaliações das alterações, uma vez que estão altamente relacionadas com as características dimensionais das microbacias. Pequenas modificações em microbacias com menores dimensões e com baixo número e comprimento de canais poderiam indicar altas taxas de variação para estas microbacias.

\section{5 - Avaliação das microbacias com base na configuração das redes de drenagem e características de uso e ocupação}

A classificação das microbacias quanto ao grau de alteração na rede de drenagem foi efetuada com base nos grupos obtidos por meio da análise de agrupamentos e discriminante (descrita no Capítulo 5), em complemento à análise gráfica relativa às taxas de variação de Dd e Dh (Figura 70). Assim, o grupo anteriormente definido como de alterações significativas (na análise de agrupamento) foi subdividido, dando origem às classes de alterações altamente significativas e alterações significativas. O mapa com a classificação das microbacias da bacia do rio Capivari é apresentado na Figura 82. 


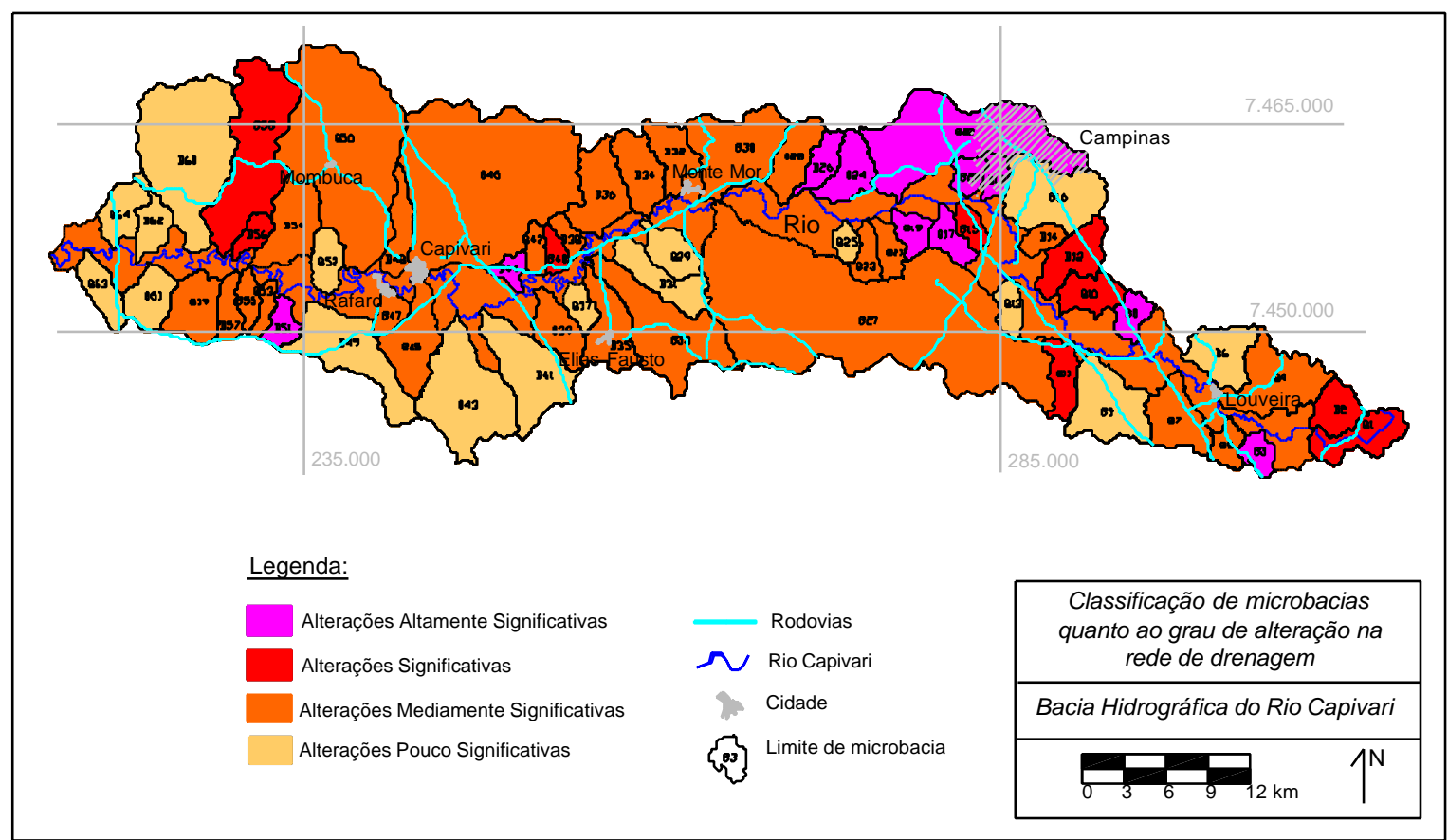

Figura 82: Mapa com a classificação das microbacias da bacia do rio Capivari quanto às alterações na rede de drenagem. 
As microbacias onde as alterações foram mais pronunciadas correspondem àquelas que combinam altas taxas de variação de densidade de drenagem e densidade hidrográfica, sendo descritas como sendo de alterações altamente significativas. O Figura 70 mostra como estas microbacias se destacam das demais, constituindo um grupo nitidamente individualizado no gráfico. Fazem parte deste grupo as microbacias: B22, B17, B44, B24, B3, B26, B20, B18, B51, B8 e B19. Destas, as microbacias B22, B17, B20, B18, B24, B26 e B19 estão situadas na região urbana e/ou periférica da cidade de Campinas.

A microbacia B22 apresentou perda de $44 \%$ na densidade hidrográfica e de $27 \%$ na densidade de drenagem. Trata-se de uma microbacia fundamentalmente urbana, que envolve parte do centro urbano de Campinas e parte da zona de expansão urbana. A remobilização de terras e a impermeabilização dos terrenos provocadas pela implantação de obras de grande porte e de loteamentos, associadas à instalação de obras de infra-estrutura, contribuiu para a desativação de canais primários naturais. A implantação do aterro sanitário Delta, da Rodovia dos Bandeirantes e a duplicação da avenida Jonh Dunlop, que dá acesso ao setor sudoeste da microbacia, também foram fatores que contribuíram neste processo.

A microbacia B17 apresentou perda de $45 \%$ na densidade hidrográfica e de $26 \%$ na densidade de drenagem. A ocupação urbana mediamente adensada que cobre cerca de $90 \%$ da microbacia foi incorporada no período entre 1972 e 1995, em decorrência da implantação de loteamentos, de um distrito industrial e de processos de ocupação desordenada (favelas). Foram estes os fatores que mais contribuíram para as significativas alterações no sistema de drenagem natural.

As microbacias $\mathrm{B} 20$ e $\mathrm{B} 18$ são microbacias urbanas contíguas e apresentaram perdas semelhantes: respectivamente, $49 \%$ na densidade hidrográfica e $17 \%$ na densidade de drenagem e $44 \%$ na densidade hidrográfica e 14\% na densidade de drenagem. Em 1972 estavam em fase de início de ocupação urbana, com alguns loteamentos já ocupados e outros em fase de implantação. Até 1995 praticamente todas as áreas foram tomadas por ocupação urbana altamente adensada, provocando a impermeabilização dos terrenos e o encobrimento dos canais primários naturais. A implantação da Rodovia dos Bandeirantes também contribuiu para as alterações na microbacia B20. 
As microbacias B24 e B26 são também microbacias contíguas e estão situadas a sudoeste da cidade de Campinas. As perdas foram, respectivamente, $44 \%$ na densidade hidrográfica e $21 \%$ na densidade de drenagem e $29 \%$ da densidade hidrográfica e 18\% na densidade de drenagem. Em 1972 eram desprovidas de qualquer tipo de ocupação urbana. Com o acesso permitido pela construção e, posteriormente, pela duplicação da avenida Jonh Dunlop foram instaladas algumas indústrias na região, fato que provocou um avanço de ocupações urbanas para estas microbacias. Além de alguns loteamentos e áreas com ocupação desordenada, destacam-se nestas microbacias atividades agrícolas intensivas de hortifruti em pequenas propriedades, áreas de empréstimo de solos e minerações de areia e argila. Estas atividades provocaram a remobilização de solos e a desconfiguração do sistema de drenagem natural, principalmente dos canais primários.

A microbacia B19 perdeu um grande número de canais de primeira ordem de pequena dimensão, daí a ocorrência de uma perda significativa na densidade hidrográfica (34\%) e uma menos significativa (10\%) na densidade de drenagem. Toda a ocupação urbana, que hoje cobre mais de $30 \%$ da área total da microbacia, foi incorporada após o ano de 1972. Foram implantados loteamentos providos de infra-estrutura urbana e também ocupações desordenadas, que promoveram a canalização ou a desconfiguração dos canais primários.

A microbacia B44, situada próxima à cidade de Capivari, apresentou perda de $46 \%$ na densidade hidrográfica e de $21 \%$ na densidade de drenagem. É cortada pela rodovia que liga Monte-Mor a Capivari e nos últimos anos se submeteu à implantação de uma indústria de grande porte e outras de pequeno porte, em uma área que foi destinada à implantação de um distrito industrial. Apesar da implantação das atividades industriais, que contribuíram para modificações no sistema de drenagem, vale a pena ressaltar que a pequena dimensão da microbacia e o pequeno número de canais tendem a superestimar as perdas ocorridas.

A microbacia B3 apresentou perda de $32 \%$ na densidade hidrográfica e de $18 \%$ na densidade de drenagem. Está situada próxima à cabeceira do rio Capivari e 
envolve uma pequena porção da área peri-urbana da cidade de Jundiaí. Em 1972 a ocupação urbana era incipiente e em 1995 atinge cerca de 12\% da área total, envolvendo bairros periféricos de Jundiaí e algumas aglomerações em áreas rurais. As áreas rurais são caracterizadas por atividades agrícolas intensivas, com o cultivo de hortifruti e a disseminação de pequenas chácaras e represas.

A microbacia B8 apresentou perda de $36 \%$ na densidade hidrográfica e $15 \%$ na densidade de drenagem. É cortada pela Rodovia Anhanguera e foi submetida, nos últimos anos, ao crescimento de áreas urbanas no entorno deste eixo e a expansão urbana da cidade de Vinhedo. Este fatores, associados ao cultivo agrícola intensivo, são potencialmente responsáveis pelas alterações no sistema de drenagem.

Das microbacias onde ocorreram as mais significativas alterações, a única que não esteve submetida a incrementos de ocupação urbana foi a microbacia B51, onde ocorreram perdas de $28 \%$ na densidade hidrográfica e $15 \%$ na densidade de drenagem. Trata-se de uma microbacia agrícola, de cultivo de cana de açúcar e que apresenta, como peculiaridade um alto índice de relação de relevo. A remobilização de terra condicionada pelo manuseio agrícola, associada à alta relação de relevo pode ter contribuído para a desconfiguração dos canais de drenagem.

O grupo de microbacias com alterações significativas apresentou alterações um pouco menos pronunciadas que estas que acabaram de ser descritas. As microbacias deste grupo apresentam perdas na densidade hidrográfica variando de 20 a $25 \%$ e na densidade de drenagem de 9 a 12\%. Das nove microbacias classificadas neste grupo, cinco são urbanizadas ou estão em processo de urbanização (B15, B12, B10, B2 e B1) e quatro são microbacias rurais (B11, B40, B56 e B58), onde há cultivo de cana de açúcar e/ou hortifruti.

As microbacias em urbanização, B15, B12 e B10 estão situadas no entorno da cidade de Campinas e sofreram intenso um processo de urbanização nas últimas décadas, motivado pela duplicação dos eixos rodoviários Rodovias dos Bandeirantes, Anhanguera e Santos Dumont, que cortam estas microbacias. Além de loteamentos dotados de infra-estrutura, ocorrem ocupações desordenadas e 
áreas industriais que estão localizadas, principalmente, nas adjacências dos eixos rodoviários.

As microbacias B2 e B1 situam-se na região de cabeceira do rio Capivari e foram submetidas a um processo de urbanização incipiente, representado por construções dispersas ao longo da rodovia Jundiaí-ltatiba e pequenas aglomerações de chácaras. Um aspecto limitante para a instalação de áreas urbanizadas nestas microbacias são os terrenos acidentados, confirmados pelos altos índices de relação de relevo.

As quatro microbacias rurais que apresentaram alterações significativas foram B11, B40, B56 e B58. Em B11 há predomínio de pastagens, porém são consideráveis as áreas com cultivo de hortifruti e de café. O que caracteriza, principalmente, esta microbacia é o alto índice de relação de relevo, que pode estar contribuindo para a desconfiguração dos canais, motivados pelo manejo agrícola.

Nas microbacias B40, B56 e B58 predominam o cultivo intensivo de cana de açúcar. O manejo agrícola e a remobilização de solos, principalmente em áreas próximas às cabeceiras, podem estar provocando o recobrimento de pequenos canais de primeira ordem e, com isto, motivando as alterações nas variáveis da rede de drenagem. As perdas ocorridas na microbacia B40 devem ser analisadas com cautela, uma vez que elas podem estar superestimadas, por ser uma microbacia de pequena dimensão e apresentar, originalmente, um número muito pequeno de canais.

As outras 44 microbacias apresentaram alterações menos significativas, sempre inferiores a $20 \%$ na densidade hidrográfica e a $10 \%$ para a densidade de drenagem. Todas elas foram analisadas e estão descritas no Apêndice 1.

Algumas microbacias, apesar uma baixa taxa de variação na densidade hidrográfica e na densidade de drenagem, apresentaram alterações internas na hierarquia dos canais que podem interferir na dinâmica das águas. Estas alterações podem ser constatadas pelas variações ocorridas nas razões de bifurcação e de comprimento médio. Este é o caso de microbacias como B21, B55 e B48 que, 
apesar de apresentarem alterações pouco significativas em Dd e Dh, registram variações superiores a 20\% nas taxas de variação de Rb1-2 e RIm2-1. 


\section{7 - CONCLUSÕES}

\section{1 - Quanto ao uso das técnicas e aplicativos de geoprocessamento}

As imagens de satélite Landsat-TM constituíram-se em um instrumento satisfatório para a obtenção do mapa de uso e ocupação, em escala regional. Cumpre ressaltar, entretanto, que para obtenção de mapas temáticos em escalas maiores, ou para a demarcação de características superficiais do terreno, como o traçado da rede de drenagem de bacias hidrográficas e delimitações de microbacias, recomenda-se recursos de sensoriamento remoto com uma melhor resolução espacial.

A obtenção da rede de drenagem por meio da interpretação de fotografias aéreas, apesar de constituir um método trabalhoso, ainda é o método mais preciso e adequado. $O$ processo informatizado, por meio do processamento das imagens de satélite comumente disponíveis no Brasil (Spot e Landsat), não permite a identificação de grande parte dos canais de primeira ordem, devido à baixa resolução espacial destas imagens.

O programa ENVI $3.0^{\circledast}$ mostrou ser um aplicativo adequado e com recursos diferenciados para o processamento de imagens rasterizadas e obtenção de mapa de uso e ocupação a partir de imagens de satélite, porém é bastante limitado para o tratamento de dados vetoriais e portanto de pouca utilidade no processamento $\mathrm{e}$ análise de redes de drenagem.

O programa Autocad Map $3.0^{\circledast}$ apresentou como principais atributos a interação e a versatilidade. $O$ programa permitiu manipular vários arquivos compostos por imagens rasterizadas e vetoriais numa mesma plataforma de trabalho, o que facilitou e tornou mais precisa a digitalização das redes de drenagem obtidas nas fotointerpretações. A versatilidade do programa permitiu 
construir mosaicos de fotografias aéreas de maneira rápida e eficiente, apesar do inconveniente de não apresentar valores numéricos que representem a eficiência do processo.

\section{2 - Quanto à análise temporal de alterações em componentes da paisagem}

A interpretação de fotografias aéreas em duas datas, com um intervalo de 23 anos, permitiu a análise comparativa de alterações ocorridas em características superficiais do terreno. Foram detectadas alterações em características de uso e ocupação do terreno e nas redes de drenagem de microbacias hidrográficas.

Utilizando-se de variáveis morfométricas das redes de drenagem de microbacias e de análise estatística discriminante, pode-se afirmar que ocorreram alterações significativas na composição da rede de drenagem da bacia hidrográfica do rio Capivari, no período entre 1972 e 1995. As variáveis que mais contribuíram para estas alterações foram a densidade de drenagem e a densidade hidrográfica.

Com base nestas variáveis, as 64 microbacias e a área adjacente ao rio Capivari puderam ser classificadas quanto ao grau de alteração, utilizando-se de análise de agrupamento, e, novamente, análise discriminante para a qualificação dos grupos.

\section{3 - Quanto ao uso de variáveis morfométricas como indicadores de alterações em bacias hidrográficas}

Dentre as variáveis retratadas no levantamento da morfometria das microbacias, dois grupos foram analisados de forma distinta: as variáveis que não sofreram alterações, denominadas variáveis morfológicas, e as variáveis passíveis de alterações, denominadas variáveis da rede de drenagem.

As variáveis morfológicas relação de relevo e índice de sinuosidade mostraram-se dependentes de características dimensionais das microbacias. Os maiores índices de relação de relevo tendem a ocorrer em microbacias de menor 
área e o índice de sinuosidade tende a ser maior para rios de maior extensão e de maior grau hierárquico.

$\mathrm{Na}$ análise de correlação entre as variáveis da rede de drenagem ocorreu uma correlação máxima na taxa de variação temporal para dois conjuntos de variáveis: Dd, Lt, Cm, Eps e Tt e para Dh, Nt e N1; o que já era esperado, considerando-se a interdependência existente entre elas. Neste contexto, escolheuse como referência uma variável de cada conjunto: a densidade de drenagem e a densidade hidrográfica. A escolha se deu pelo fato destas variáveis se constituírem em parâmetros amplamente difundidos e aceitos como significativos em análises geoambientais de bacias hidrográficas.

Alterações nas variáveis razão de bifurcação e razão de comprimento médio também foram importantes uma vez que podem indicar alterações nas interações entre canais de diferentes ordens hierárquicas sem que, necessariamente, tenha havido mudanças na quantidade de rios ou no comprimento total de canais.

Apesar de serem derivadas, respectivamente, de um parâmetro dimensional e outro adimensional, a densidade de drenagem e a densidade hidrográfica apresentaram um alto grau de correlação indicando que o desaparecimento de canais de primeira ordem tende a interferir na dinâmica das águas, diminuindo na mesma proporção sua capacidade de escoamento linear.

Com relação à influência das dimensões das microbacias no valor da densidade de drenagem, não foi observada nestas análises uma tendência típica de comportamento, como descrevem Horton (1945) e Christofolleti (1979), inferindo que bacias de menor porte e de grau hierárquico mais elevado tendem a apresentar valores mais elevados.

A composição do substrato rochoso mostrou-se influente tanto na densidade de drenagem quanto na densidade hidrográfica. As microbacias em substrato de arenito apresentaram valores de densidade de drenagem baixos enquanto as microbacias com substrato granito-gnáissico os valores foram mais elevados. $O$ mesmo comportamento ocorreu com a densidade hidrográfica. 
$\mathrm{Na}$ análise das alterações temporais, as taxas de variações mostraram-se influenciadas pelos valores ocorrentes antes das alterações. As maiores alterações tenderam a ocorrer em microbacias que apresentavam valores mais baixos de densidade de drenagem e hidrográfica, em 1972. Entretanto, algumas microbacias apresentaram perdas significativas mesmo com densidade de drenagem e densidade hidrográfica altos, originalmente.

Em todas as microbacias onde há predomínio de áreas urbanizadas ocorreram alterações significativas na rede de drenagem e o mesmo aconteceu com algumas microbacias mistas que estão em processo de expansão urbana. Nas microbacias rurais, com predomínio de pastagens e/ou cana de açúcar as alterações foram menos pronunciadas.

\section{4 - Quanto às alterações verificadas na bacia hidrográfica do rio Capivari e classificação de suas microbacias}

Alterações ocasionadas pelas atividades antrópicas, refletiram em um aumento em torno a $380 \%$ nas áreas urbanizadas, motivado, principalmente, pela expansão da área urbana na cidade de Campinas e ao longo dos eixos rodoviários que cortam a porção leste da bacia. As áreas identificadas como mineradas ou de disposição de resíduos também sofreram alterações significativas, com um aumento em torno de $270 \%$ nas áreas ocupadas por estas atividades, estando as maiores concentrações situadas às margens do rio Capivari. O aumento em áreas ocupadas por represas foi em torno de $100 \%$.

Das onze microbacias classificadas como de alterações altamente significativas, sete (B22, B17, B20, B18, B24, B26 E B19) compreendem a área central ou periférica de Campinas e sofreram alterações motivadas por processos urbanos ou de expansão urbana. A remobilização de terras e impermeabilização dos terrenos provocadas pela implantação de obras de grande porte e de loteamentos contribuiu para a desativação de canais primários naturais. A implantação de obras como o aterro sanitário Delta, a Rodovia dos Bandeirantes e a duplicação da avenida Jonh Dunlop também contribuíram para alterar a dinâmica de escoamento linear das águas. 
As microbacias B8 e B3 sofreram com o processo de urbanização no entorno da Rodovia Anhanguera e da área periférica de Jundiaí, respectivamente. Também são comuns a estas microbacias atividades agrícolas intensivas, com o cultivo de hortifruti e a disseminação de pequenas chácaras. A microbacia B44, situada próxima à cidade de Capivari, é cortada por rodovias asfaltadas e após 1972 se submeteu à implantação de uma indústria de grande porte e outras de pequeno porte em uma área preparada para a implantação de um distrito industrial.

Das microbacias classificadas como de alterações altamente significativas, a única que não esteve submetida a incrementos de ocupação urbana foi a microbacia B51. Trata-se de uma microbacia agrícola, de cultivo de cana de açúcar. A remobilização de terra condicionada pelo manuseio agrícola, associada à alta relação de relevo deve ter contribuído para o desconfiguração dos canais de drenagem.

Considerando-se as nove microbacias classificadas como de alterações significativas, cinco são microbacias urbanizadas ou em processo de urbanização (B1, B15, B10, B2 e B12) e quatro são microbacias rurais (B11, B56, B58, e B40). No primeiro caso compreendem parte da periferia de Campinas, de Jundiaí ou áreas em processo de urbanização ao longo das rodovias que cortam a bacia.

Nas quatro microbacias rurais há ocorrência de extensas áreas agrícolas, principalmente com cultivo intensivo de cana de açúcar. O manejo agrícola e a remobilização de solos, principalmente em áreas próximas às cabeceiras, podem estar provocando o recobrimento de pequenos canais primários e, com isto, motivando as alterações nos parâmetros morfométricos.

Dentre as microbacias classificadas como de alterações mediamente significativas e alterações pouco significativas, algumas apresentaram alterações internas na hierarquia dos canais, comprovadas pelas altas taxas de variação da razão de bifurcação e razão de comprimento médio. Estas alterações podem interferir na dinâmica das águas. 


\section{8 - RECOMENDAÇÕES}

O desenvolvimento das atividades desta pesquisa permitiu vislumbrar algumas possibilidades de continuidade e aprimoramento de determinados tópicos sobre o tema que serão expostos a seguir:

a) Desenvolver algorítmos para o traçado digital da rede de drenagem, na mesma linha dos produzidos por autores como Band (1989) e Meisels et al (1995), porém de forma que permita o delineamento de canais pluviais de primeira ordem.

\section{Comentários:}

Certamente a etapa mais trabalhosa da metodologia aplicada neste trabalho foi a efetivação do traçado e a digitalização das redes de drenagem, devido ao grande número de fotografias áereas. O recente lançamento de satélites comerciais já permite a obtenção de imagens com resolução espacial e espectral bem superior às disponíveis e deverão estar no mercado, com preços acessíveis, em um futuro próximo. Imagens com tal resolução deverão possibilitar a discriminação de canais pluviais de primeira ordem de ramificação que não são passíveis de obtenção nas imagens Spot e Landsat.

b) Aumentar o número de observações e diminuir o período entre observações na análise temporal das alterações com o uso de imagens.

\section{Comentários:}

A otimização no processo de obtenção da rede de drenagem tornará viável análises com um maior número de exposições do terreno em datas distintas e períodos mais curtos. Este procedimento deverá permitir a elaboração de um histórico das alterações e assim identificar o período onde as alterações foram mais pronunciadas. Estas análises, aliadas a um histórico de uso e ocupação, poderão indicar as formas de atuação antrópica mais influentes no processo. 
c) Efetuar experimentações utilizando microbacias com características dimensionais semelhantes ou de mesma ordem de ramificação.

\section{Comentários:}

Apesar desta ser uma recomendação de alguns autores que trabalham com análise morfométrica em outros campos de atuação, em algumas situações pode não ser viável em estudos com o enfoque deste trabalho. Alguns motivos podem ser citados:

- O número de casos pode não ser suficiente para análises estatísticas ou pode não cobrir toda a área da bacia;

- Por se tratar de análise temporal, caso sejam escolhidas microbacias de pequenas dimensões ou de menor ordem hierárquica, em datas distintas a microbacia pode já não ter mesma ordem ou pode até mesmo ter sido eliminada, dificultando, assim, as comparações;

- As dimensões ou ordem escolhidas como padrão para as microbacias podem não ser as mesmas adotadas pelos órgãos de gestão, dificultando, assim, a utilização dos produtos gerados com o trabalho.

d) Sugestões para a adaptação do uso desta metodologia em microbacias (escala local).

\section{Comentários:}

À medida que a metodologia foi sendo desenvolvida e aplicada na bacia do rio Capirari, alguns trabalhos de mestrado (Silva, 2000; Siqueira, em execução; Ribeiro, em execução) estavam, também, aplicando-a em microbacias desta bacia hidrográfica. Aproveitando as experiências adquiridas neste trabalho como também as obtidas nestas dissertações serão apresentadas algumas adaptações que poderão viabilizar o uso desta sistemática também em escalas maiores.

d1) Levantamento de características de uso e ocupação em microbacias.

Para aplicação em microbacias os mapas de uso e ocupação poderão ser obtidos a partir de fotografias aéreas. Este procedimento só é viável, entretanto, para áreas não muito grandes, uma vez que necessita de um efetivo controle de campo. Uma outra alternativa é o uso de imagens de satélite com uma melhor 
resolução espacial que as Landsat-TM como, por exemplo, as imagens SPOT, que também são muito comuns no Brasil.

O uso de imagens SPOT, ou alguma outra com melhor resolução espacial, deverá permitir uma maior discriminação de classes. Por exemplo, poderão permitir a distinção dentro da classe de áreas urbanas de áreas com ocupações desordenadas (favelas), como também discriminar diferentes tipos de culturas agrícolas.

d2) Monitoramento das alterações

No caso de escalas locais, além das variáveis da rede de drenagem, as variáveis morfológicas podem, também, estar sofrendo alterações passíveis de monitoramento, principalmente algumas variáveis relativas a dimensões e forma das encostas. A obtenção de modelos digitais do terreno (MDT), por meio de mapas topográficos de diferentes datas, pode ser útil para a avaliação destas alterações. Em todos os casos de alterações, deve-se avaliar a influência de outros componentes do meio físico no processo, tais como declividades, materiais inconsolidados e substrato rochoso.

Conforme a situação encontrada, após o levantamento das características de uso e ocupação e intervenções antrópicas na microbacia, pode ser necessário o monitoramento da qualidade das águas, além da análise das alterações em componentes da paisagem com o uso de imagens remotas, como o efetuado na ánalise regional. 


\section{9 - REFERÊNCIAS BIBLIOGRÁFICAS}

ABU-JABER, N.S.; ALOOSY, A .S.; ALI, A .J. (1997). Determination of aquifer susceptibility to pollution using statistical analysis. Environmental Geology. v.31. No1/2. p. 94-106.

ANGULO FILHO, R. (1981). Variações de características de redes de drenagem em função das fotografias aéreas verticais obtidas em épocas diferentes. Piracicaba. 128p. Dissertação (Mestrado). Escola Superior de Agronomia "Luiz de Queiróz" - Universidade de São Paulo.

ANGULO FILHO, R. (1986). Caracterização da drenagem e do relevo de três solos do estado de São Paulo através de fotografias aéreas e cartas planialtimétricas. Piracicaba. 132p. Tese (Doutorado). Escola Superior de Agronomia Luiz de Queiroz - Universidade de São Paulo.

ARONOFF, S. (1989). Geographical Information Systems: a management perspective. Ottawa, WDI Publications. 294p.

ASSIS, R. B. (1996). Estágio da política estadual de recursos hídricos e do comitê das bacias hidrográficas dos rios Piracicaba, Capivari e Jundiaí. In: WORKSHOP DO PROJETO PIRACENA, 2. Nazaré Paulista - SP, 1996. Anais. Piracicaba, CENA, p.18-25.

AUTODESK, Ins. (1998). Programa Autocad Map ${ }^{\circledR}$, versão 3.0. San Rafael Canadá.

BAND, L.E. (1986). Topographif partition of watersheds with digital elevation models. Water Resources Research. v.22, p.15-24. 
BAND, L.E. (1989). A terrain-based watershed information system. Hydrological Processes. v.3, p.151-162.

BARROS, Z. X.; CAMPOS, S.; CARDOSO, L. G. (1996). Distribuição espacial dos solos do município de Itobi - SP de acordo com agrupamento de variáveis dimensionais. Engenharia Agrícola, v.16, n.1, p.35-44.

BARROS, Z. X.; PIEDADE, G. C. R.; CURI, P. R.; CARDOSO, L. G. (1991). Variáveis dimensionais e análise multivariada. Científica, v.19, n.1, p.83-92.

BERGER, A. R. (1996). Introduction to geoindicator checklist. In: Berger, A. R. \& lams, W. J. ed. Geoindicators: Assessing rapid environmental changes in earth systems. Rotterdan. AA Balkema. p.383-454.

BISORDI, M. S. (1999). Encerramento e projetos de recuperação ambiental de aterros sanitários. In: SEMINÁRIO SOBRE RESÍDUOS SÓLIDOS, RESID’99. São Paulo, 1999. Anais. São Paulo, ABGE, p. 69-82

BITAR, O.Y. coord. (1995). Curso de geologia aplicada ao meio ambiente. São Paulo, IBGE/IPT Divisão de Geologia (Série Meio Ambiente). 247p.

BOURLON, N.; BERTHON, D. (1993). Desenvolvimento sustentável e gerenciamento das bacias hidrográficas na América Latina. Ciência e Cultura. p.16-22.

BURROUGH, P. A. (1986). Principles of geographic information systems for land resources assessment. Oxford, Oxford University Press. 193p.

CÁMARA, G. (1994). Anatomia de um SIG. Fator GIS: a Revista do Geoprocessamento, n.4, p. 11-15.

CAMPBELL, D.J.V. (1993). Environmental management of landfill sites. Journal of the Institution of Water and Environmental Management, v.7, p. 170-174. 
CARVALHO, W. A. (1977). Fotointerpretação de bacias hidrográficas e amostras circulares de redes de drenagem de solos com horizonte $B$ textural. Piracicaba. $126 p+$ anexos. Tese (Doutorado). Escola Superior de Agronomia Luiz de Queiroz - Universidade de São Paulo.

$\mathrm{CBH}-\mathrm{PCJ}$ - Comitê das Bacias Hidrográficas dos rios Piracicaba, Capivari e Jundiai - (1996). Plano integrado de aproveitamento dos recursos hídricos das bacias Alto Tietê, Piracicaba e baixada Santista. CERH/DAEE/HIDROPLAN. São Paulo, DAEE. (Relatório resumo).

CBH-PCJ - Comitê das Bacias Hidrográficas dos rios Piracicaba, Capivari e Jundiai - (1997). Plano integrado de aproveitamento e controle dos recursos hídricos das bacias Alto Tietê, Piracicaba e baixada Santista. CERH/DAEE/HIDROPLAN. São Paulo, DAEE. (Relatório resumo).

CETESB - Companhia de Tecnologia e Saneamento Ambiental - (1991a). Controle da poluição ambiental na bacia do rio Capivari. São Paulo, CETESB. (Série relatórios).

CETESB - Companhia de Tecnologia e Saneamento Ambiental - (1991b). Relatório de qualidade das águas interiores do Estado de São Paulo 1995. São Paulo, CETESB. (Série relatórios).

CETESB - Companhia de Tecnologia e Saneamento Ambiental - (1992). Relatório de qualidade das águas interiores do Estado de São Paulo 1995. São Paulo, CETESB. (Série relatórios).

CETESB - Companhia de Tecnologia e Saneamento Ambiental - (1993a). Diagnóstico da poluição ambiental no interior do Estado de São Paulo - bacia do rio Capivari. São Paulo, CETESB. (Série relatórios).

CETESB - Companhia de Tecnologia e Saneamento Ambiental - (1993b). Relatório de qualidade das águas interiores do Estado de São Paulo 1995. São Paulo, CETESB. (Série relatórios). 
CETESB - Companhia de Tecnologia e Saneamento Ambiental - (1994). Relatório de qualidade das águas interiores do Estado de São Paulo 1995. São Paulo, CETESB. (Série relatórios).

CETESB - Companhia de Tecnologia e Saneamento Ambiental - (1995a). Relatório de qualidade das águas interiores do Estado de São Paulo 1995. São Paulo, CETESB. 286p. (Série relatórios).

CETESB - Companhia de Tecnologia e Saneamento Ambiental - (1995b). Legislação Estadual: controle de poluição ambiental - Estado de São Paulo. São Paulo, CETESB. (Série Documentos).

CETESB - Companhia de Tecnologia e Saneamento Ambiental - (1996). Consolidação do inventário das fontes fixas - poluição das águas - UGRHI Piracicaba/Capivari/Jundiai. São Paulo, CETESB. (Série relatórios).

CETESB - Companhia de Tecnologia e Saneamento Ambiental - (1997). Empresas extrativas na bacia do Capivari. São Paulo, CETESB. (Relatório interno).

CHRISTOFOLETTI, A . (1969). Análise morfométrica das bacias hidrográficas. Campinas. Notícias Geomorfológicas. v.9, n.18, p.19-34.

CHRISTOFOLETTI, A. (1974) Geomorfologia. 2ed. São Paulo. Ed. Edgard Blucher Ltda.

CHRISTOFOLETTI, A. (1979). A análise da densidade de drenagem e suas implicações geomorfológicas. Geografia. V. 4, n. 8, p. 23-42.

CHRISTOFOLETTI, A. (1996). Proposta de gestão para o desenvolvimento sustentável em microbacias hidrográficas. In: WORKSHOP DO PROJETO PIRACENA, 2. Nazaré Paulista - SP, 1996. Anais. Piracicaba, CENA, p.4144. 
CIVCO, D. L.; GARCIA, A. R.; WARNER, G.S. (1995). Key steps to effective watershed characterization. GIS World. Nov.95, p. 62-67.

COLWELL, R. N. (1983). Manual of remote sensing: Interptretation and applications. Washington. American Society of photogrammetry.

CORSON, W.H. ed. (1993). Manual global de ecologia: o que voce precisa saber a respeito da crise no meio ambiente; trad. de A.G. Camaru. São Paulo, Augustus. 413p.

CRÓSTA, A. P. (1993). Processamento digital de imagens de sensoriamento remoto. Campinas. UNICAMP.

CUNHA, M.A. \& CONSONI, A.J. (1995). Os estudos do meio físico na disposição de resíduos. In: BITAR, O.Y., coord. Curso de geologia aplicada ao meio ambiente. São Paulo, ABGE/IPT. p. 217-227.

DAEE - Departamento de Água e Energia Elétrica - (1998). Banco de dados pluviométricos do Estado de São Paulo. (CD ROM). Centro Tecnológico de Hidráulica e recursos Hídricos - Covênio DAEE - USP, versão 1.

DAEE/UNESP - Departamento de Águas e Energia Elétrica/Universidade Estadual Paulista - (1982). Mapa geológico do Estado de São Paulo: Folhas Campinas e São Paulo, escala 1:250.000. Rio Claro.

DAVIS, J. C. (1986). Statistics and data analysis in geology. 2 ed. USA. John Wiley \& Sons.

DEMÉTRIO, V.A. (1977). Variação de características de redes de drenagem em função da escala de fotografias aéreas verticais. Piracicaba. 107p. Dissertação (Mestrado). Escola Superior de Agronomia Luiz de Queiroz Universidade de São Paulo. 
DNPM - Departamento Nacional de Produção Mineral - (1979). Mapas geológicos 1:100.000. Projeto Sapucaí. Convênio DNPM/CPRM. Estados de São Paulo, Rio de Janeiro e Minas Gerais. Brasília: SUREG/SP.

DNPM/CPRM - Departamento Nacional de Pesquisa Mineral / Companhia de Pesquisa de Recursos Minerais - (1984a). Projeto Borda Leste da Bacia do Paraná. Mapa Geológico: Campinas, Folha SF-23-Y-A-V. Rio de Janeiro, DNPM/CPRM. Escala 1:100.000. 1 mapa.

DNPM/CPRM - Departamento Nacional de Pesquisa Mineral / Companhia de Pesquisa de Recursos Minerais - (1984b). Projeto Borda Leste da Bacia do Paraná. Mapa Geológico: Itu, Folha SF-23-Y-C-II. Rio de Janeiro, DNPM/CPRM. Escala 1:100.000. 1 mapa.

DNPM/CPRM - Departamento Nacional de Pesquisa Mineral / Companhia de Pesquisa de Recursos Minerais - (1984c). Projeto Borda Leste da Bacia do Paraná. Mapa Geológico: Piracicaba, Folha SF-23-Y-A-IV. Rio de Janeiro, DNPM/CPRM. Escala 1:100.000. 1 mapa.

DNPM/CPRM - Departamento Nacional de Pesquisa Mineral / Companhia de Pesquisa de Recursos Minerais - (1984d). Projeto Borda Leste da Bacia do Paraná. Mapa Geológico: Tatuí, Folha SF-23-Y-C-I. Rio de Janeiro, DNPM/CPRM. Escala 1:100.000. 1 mapa.

DOYLE, D. (1991). Sustainable development: growth without losing ground. Journal of Soil and Water Conservation, v.46, n.1, p. 8-12.

DUINKER, P. N.; BEANLANDS, G. E. (1986). The significance of environmental impacts: na exploration of the concept. Environmental Management. New York, v.10, n.2, p. 166-170.

EMPLASA (1997). Dados: Região de Campinas. São Paulo: http://www.emplasa.sp.gov.br (28/7/00). 
FAO (1995). Land and water integration and river basin management. Rome. FAO Land and Water Bulletin n.1. 81p.

FERREIRA, M.C.(1996). Modelagem cartográfica aplicada a mapeamentos de susceptibilidade a danos ambientais : um ensaio no SIG IDRISI. São Paulo. Geociências. v.15, n.2, p. 485-502.

FERREIRA, M.C.(1997). Utilização de modelos digitais de terreno na estimativa de enchentes em bacias hidrográficas: uma avaliação preliminar em escala regional. São Paulo. Geociências. v.16, n.1, p.243-255.

FERREIRA, M.C.(1999). Análise espacial da densidade de drenagem em sistema de informação geográfica através de um modelo digital de distâncias enterfluviais. São Paulo. Geociências. v.18, n.1, p.7-22.

FJP - Fundação Jõao Pinheiro - (1998). A questão ambiental em Minas Gerais: discurso e política. Belo Horizonte, FJP/FEAM/FAPEMIG.

FONTES, A. L. (1997). Caracterização geoambiental da bacia do rio Japaratuba SE. Rio Claro. 283p. Tese (Doutorado) - Instituto de Geociências e Ciências Exatas, Universidade Estadual Paulista.

FORNASARI FILHO, N. coord. (1992). Alterações no meio físico decorrentes de obras de engenharia. São Paulo, IPT (Boletim 61). 165p.

FRANÇA, G. V. (1968). Interpretação fotográfica de bacias e de redes de drenagem aplicada a solos da região de Piracicaba. Piracicaba. 151p. Tese (Doutorado). Escola Superior de Agronomia Luiz de Queiroz - Universidade de São Paulo.

GANDOLFI, N. (1968). Bacia do Moji-Guaçu: morfometria da drenagem, sedimentologia e investigações físico-químicas. São Carlos. 124p. + anexos. Tese (Doutorado). Escola de Engenharia de São Carlos, Universidade de São Paulo. 
GANDOLFI, N. (1971). Investigações sedimentológicas, morfométricas e físicoquímicas nas bacias do Moji-Guaçu, do Ribeira e do Peixe. São Carlos. 108p. Tese (Livre-docência). Escola de Engenharia de São Carlos, Universidade de São Paulo.

GARBRECHT, J. \& MARTZ, L.W. (1997). Automated channel ordering and node indexing for raster channel networks. Computers \& Geosciences. v.23, n.9, p.961-966.

HORTON, R. E. (1945). Erosional development of streams and their drainage basins: hydrophysical approach to quantitative morphology. Bulletin of the geological Society of America. v. 56, p. 275-370.

HRKAL, Z. \& TROVILLARD, J.M. (1994). Use of GIS for optimization of human activity in a catchment area: an exemple of the Beauce Region (France). Environmental Geology, v.24, p. 22-27.

IBGE - Instituto Brasileiro de Geografia e Estatística - (1970a). Mapa topográfico: Americana, Folha SF-23-M-IV-3. Rio de Janeiro, IBGE. (Levantamento aerofotogramétrico topográfico regular aerofotografias de 1965). Escala 1:50.000. 1 mapa color. $60 \times 70 \mathrm{~cm}$.

IBGE - Instituto Brasileiro de Geografia e Estatística - (1970b). Mapa topográfico: Capivari, Folha SF-23-M-III-4. Rio de Janeiro, IBGE. (Levantamento aerofotogramétrico topográfico regular aerofotografias de 1965). Escala 1:50.000. 1 mapa color. $60 \times 70 \mathrm{~cm}$.

IBGE - Instituto Brasileiro de Geografia e Estatística - (1970c). Mapa topográfico: Ibitiruna, Folha SF-23-M-III-3. Rio de Janeiro, IBGE. (Levantamento aerofotogramétrico topográfico regular aerofotografias de 1965). Escala 1:50.000. 1 mapa color. $60 \times 70 \mathrm{~cm}$.

IBGE - Instituto Brasileiro de Geografia e Estatística - (1970d). Mapa topográfico: Porto Feliz, Folha SF-23-Y-C-I-2. Rio de Janeiro, IBGE. (Levantamento 
aerofotogramétrico topográfico regular aerofotografias de 1965). Escala 1:50.000. 1 mapa color. $60 \times 70 \mathrm{~cm}$.

IBGE - Instituto Brasileiro de Geografia e Estatística - (1971). Mapa topográfico: Jundiaí, Folha SF-23-Y-C-III-1. Rio de Janeiro, IBGE. (Levantamento aerofotogramétrico topográfico regular aerofotografias de 1962). Escala 1:50.000. 1 mapa color. $60 \times 70 \mathrm{~cm}$.

IBGE - Instituto Brasileiro de Geografia e Estatística - (1973a). Mapa topográfico: Indaiatuba, Folha SF-23-Y-C-II-2. Rio de Janeiro, IBGE. (Levantamento aerofotogramétrico topográfico regular aerofotografias de 1965). Escala 1:50.000. 1 mapa color. $60 \times 70 \mathrm{~cm}$.

IBGE - Instituto Brasileiro de Geografia e Estatística - (1973b). Mapa topográfico: Salto, Folha SF-23-Y-C-II-1. Rio de Janeiro, IBGE. (Levantamento aerofotogramétrico topográfico regular aerofotografias de 1965). Escala 1:50.000. 1 mapa color. $60 \times 70 \mathrm{~cm}$.

IBGE - Instituto Brasileiro de Geografia e Estatística - (1974). Mapa topográfico: Campinas, Folha SF-23-Y-A-V-4. Rio de Janeiro, IBGE. (Levantamento aerofotogramétrico topográfico regular aerofotografias de 1965). Escala 1:50.000. 1 mapa color. $60 \times 70 \mathrm{~cm}$.

IBGE - Instituto Brasileiro de Geografia e Estatística (1994). São Paulo em dados. São Paulo: http://www.sidra.ibge.gov.br/cgi-bin/prtabl (7/5/97).

IG - Instituto Geológico - (1993). Subsídios do meio físico geológico ao planejamento do município de Campinas - SP. Programa: cartas geológicas e geotécnicas para planejamento ambiental na região entre Sorocaba e Campinas. Secretaria do Meio Ambiente do Estado de São Paulo - CINP. (relatórios técnicos), $2 \mathrm{v}$.

IPT - Instituto de Pesquisas Tecnológicas do Estado de São Paulo - (1981). Mapa geomorfológico do Estado de São Paulo: escala 1:1.000.000. São Paulo. 2v. (IPT monografias 6). 
JAKUBAUSKAS, M.E; WHISTLER, J.L; DILLWORTH, M.E; MARTINKO, E.A. (1992). Classifying remotely sensed data for use in an agricultural nonpoint source pollution model. Journal of Soil and Water Conservation, v.47, n.2, p. 179-183.

JENSEN, J. R. (1986). Introductory digital image processing. New Jersey: PrenticeHall. 379p.

JUCESP - Junta Comercial do Estado de São Paulo - (1998). São Paulo: geografia de negócios. (CD ROM) Revista Cd Expert. Ano 1. n. 8. $2^{\mathrm{a}}$ ed.

KERTZMAN, F.F; GOUVEIA, M.I.F; MANO, V.G.T (1991). Orientações para o combate à erosão no Estado de São Paulo. IPT/DAEE, v1. São Paulo, IPT.

LANDIM, P. M. B. (1997). Análise estatística de dados geológicos multivariados. Publicação didática n.5 - Instituto de Geociências e Ciências Exatas, Universidade Estadual Paulista - Campus Rio Claro.

LANNA, A. E. L. (1995) Gerenciamento de bacia hidrográfica: aspectos conceituais e metodológicos. Brasília, IBAMA.

LENT, R.M.; WALDRON, M.C.; RADER, J.C. (1998). Multivariate classification of small order watersheds in the Quabbin Reservoir Basin, Massachusetts. Journal of the American Water Resources Association. v.34, n.2, p. 439-450.

LEOPOLD, L.B; CLARKE, F.S; HANSHAW,B.B; BASLEY, J.R. (1971). A procedure for evaluating environmental impact. United States Geological Survey; circ. 645. Washington, D.C. 13p.

LIMA, S. L. de. (1987). Características da rede de drenagem e do relevo de três solos do estado de São Paulo, determinadas em fotografias aéreas e cartas planialtimétricas. Piracicaba. 100p. Tese (Doutorado). Escola Superior de Agronomia Luiz de Queiroz - Universidade de São Paulo. 
MÁGLIO, I.C. (1991). A política ambiental e o desenvolvimento. Ambiente - Revista CETESB de tecnologia, v.5, n.1, p. 41-46.

MANIAKAS, S. (1986). Estudos Geofísicos integrados a geologia da bacia hidrográfica do baixo rio Capivari - SP - Subgrupo Itararé e Intrusivas Básicas associadas. São Paulo. 180p. Tese (Doutorado) - Instituto de Geociências, Universidade de São Paulo.

MANLY, B. F. J. (1986). Multivariate statistical methods: a primer. New York. Chapman and Hall Ltd.

MASCARENHAS, G.R. (1989). Aspectos ambientais na elaboração do plano de aproveitamento econômico - (P.A.E.). In: SIMPÓSIO EPUSP SOBRE CONTROLE AMBIENTAL E SEGURANÇA EM MINERAÇÃO, São Paulo, 1989. editado pela EPUSP, 1989. p. 177-187.

MATHER, P. M. (1987). Computer processing of remotely-sensed images. Chichester - New York -Brisbane - Toronto - Singapore: John Wiley \& Sons. $352 p$.

McDONALD, G.T. \& BROWN, L. (1995). Going beyond environmental impact assessment: environmental input to planning and design. Environmental Impact Assessment, 15, p. 483-495.

MEISELS, A.; RAIZMAN, S.; KARNIELI, A. (1995). Skeletonizing a DEM into a drainage network. Computers \& Geosciences. v.21, n.1, p. 187-196.

MICROSOFT Inc. (1997). Programa Access ${ }^{\circledR}$, versão 1997. São Paulo - SP.

MOIK, J. G. (1980). Digital Processing of remotely sensed images. Washington, DC: NASA. 330p.

MORISAWA, M.E. (1962). Quantitative geomorphology of some watersheds in the Appalachian Plateau. Geological Society of America Bulletin. v.73, n.9, p.1025-1046. 
NOVO, E. M. L. M. (1989). Sensoriamento remoto: princípios e aplicações. São Paulo. Ed. Edgard Blucher Ltda. 308p.

PATTON, P.C.; BAKER, V.R. (1976). Morphometry and floods in small drainage basins subject to diverse hydrogeomorphic controls. Water Resources Research. v.12, n.5, p.941-952.

PEJON, O. L. (1992). Mapeamento geotécnico de Piracicaba 1:100.000: estudo de aspectos metodológicos, de caracterização e de apresentação de atributos. São Carlos. 2v. Tese (Doutorado). Escola de Engenharia de São Carlos Universidade de São Paulo.

PHILIPPI Jr., A. (1999). Agenda 21 e resíduos sólidos. In: SEMINÁRIO SOBRE RESÍDUOS SÓLIDOS, RESID’99. São Paulo, 1999. Anais. São Paulo, ABGE, p. 15-26.

PIEDADE, G. C. R.; CARVALHO, W. A.; PFEIFER, R. M. (1984). Relações entre parâmetros dimensionais de bacias hidrográficas. Científica, v. 12, p.9-14.

PIRES NETO A. G. (1996). Estudo morfotectônico das bacias hidrográficas dos rios Piracicaba, Capivari, Jundiaí e áreas adjacentes no Planalto Atlântico e Depressão Periférica. Proj. CNPq 150011/94-6, realizado em IGCE-UNESP. Rio Claro. 71p.

PIRES, J.S.R. \& SANTOS, J.E. dos (1995). Bacias hidrográficas: integração entre meio ambiente e desenvolvimento. Ciência Hoje, v.19, n.110, p.40-45.

PMC - Prefeitura Municipal de Campinas - (1995). Campinas: Plano diretor. Campinas. Prefeitura Municipal.

POLITANO, W. (1980). Estudo fotointerpretativo sobre a morfometria das áreas de dois solos podzólicos vermelho-amarelos. Piracicaba. 169p. Tese (Doutorado). Escola Superior de Agronomia Luiz de Queiroz - Universidade de São Paulo. 
POLITANO, W.; AMARAL, C.; LOPES, L.R. (1995). Relacionamento entre bacias hidrográficas de diferentes ordens de magnitude. São Paulo, Científica, v.23, n.1, p.73-83.

POLITANO, W.; FRANÇA, G. V.; CORSINI, P. C.; LOPES, L. R.; BANZOTTO, D. A. (1991). Avaliação dos critérios de amostragem da bacia hidrográfica e amostra circular na determinação de características quantitativas do relevo e rede de drenagem, em áreas de solos podzólicos vermelho-amarelos. Científica, v.19, n.1, p.71-81.

POLITANO, W.; LOPES, L.R.; CORSINI, P.C.; AMARAL, C. (1994). Influência do relevo sobre o desenvolvimento de bacias hidrográficas de áreas com solos podzólicos vermelho-amarelos e latossolos das sub-regiões de Jaboticabal, Ribeirão Preto e Araraquara (SP). São Paulo. Científica. v.22, n.2, p.263-276.

PRANDINI, F.L.; NAKAZAWA, V.A.; FREITAS, C.G.L; DINIS, N.C. (1995). Cartografia geotécnica nos planos diretores regionais e municipais. In: BITAR, O.Y., coord. Curso de geologia aplicada ao meio ambiente. São Paulo, ABGE/IPT. p. 189-202.

PROCHNOW, M. C. R. (1990). Análise ambiental da sub-bacia do rio Piracicaba: Subsídios ao seu planejamento e manejo. 330p. Rio Claro. Tese (Doutorado). Instituto de Geociências e Ciências Exatas, Universidade Estadual Paulista.

RABBEN, E. L. (1960). Fundamentals of photo interpretation. In: Manual of photogrammetry. Washington. American Society of photogrammetry. P.99168.

RAMESH, V; KUMAR, K.S; ESWARAMOORTHI, S; PURVAJA, G.R. (1995). Migration and contamination of major and trace elements in groundwater of Madras City, India. Environmental Geology, v.25, p. 126-136.

RESEARCH SYSTEMS, Inc. (1998). Programa ENVI - Environment for Visualizing Images ${ }^{\circledR}$, versão 3.0. Boulder, CO - USA. 
RIBEIRO, R. P. (no prelo). Zoneamento geoambiental das microbacias do Ribeirão do aterrado, Ribeirão do Pombal e Córrego Água Suja (título provisório). (Mestrado em andamento). Escola de Engenharia de São Carlos Universidade de São Paulo.

ROSS, J.L.S.; DEL PRETTE, M.E. (1998). Recursos hídricos e as bacias hidrográficas: âncoras do planejamento e gestão ambiental. Revista do Departamento de Geografia. n.12, p.89-121.

SAITO, L; GRIGG, N.S; WARD, R.C. (1994). Water-quality data management: survey of corrente trend. Journal of Water Resources Planning and Management, v. 120, n.5, p. 587-612.

SALOMÃO, F.X.T. \& IWASA, O.Y. (1995). Erosão e a ocupação rural e urbana. In: BITAR, O.Y., coord. Curso de geologia aplicada ao meio ambiente. São Paulo, ABGE/IPT. p. 31-57.

SCHOWENGERDT, R. A. (1983). Techniques for image processing and classification in remote sensing. New York: Academic Press. 249p.

SCHUMM, S. A. (1956). Evolution of drainage systems and slopes in badlands at Perth Amboy, New Jersey. Bulletin of the geological Society of America. v. 67, p. 597-646.

SEAGER, J; JONES, F; RUTT, G. (1992). Assessment and control of farm pollution. Journal of the Institution of Water and Environmental Management, v.6, p. 4854.

SETTI, A. A. (1996). A necessidade do uso sustentável dos recursos hídricos. Brasília, IBAMA.

SETZER, J. (1966). Atlas climático do Estado de São Paulo. São Paulo, Secretaria de Agricultura. 
SHENG, T.C.; BARRETT, R.E.; MITCHELL, T.R. (1997). Using geographic information systems for watershed classification and rating in developing countries. Journal of Soil and Water Conservation. v.52, n.2, p.84-89.

SILVA, L. C. F. da (1993). Fotointerpretação de redes de drenagem e caracterização do relevo de dois solos do município de São Pedro - SP. Piracicaba. 125p. Tese (Doutorado). Escola Superior de Agronomia Luiz de Queiroz - Universidade de São Paulo.

SILVA, S. F. (2000). Avaliação das alterações ambientais na sub-bacia hidrográfica do Ribeirão do Piçarrão - Campinas - SP. São Carlos. 200p. Dissertação (Mestrado). Escola de Engenharia de São Carlos - Universidade de São Paulo.

SIQUEIRA, A. G. (no prelo). Zoneamento geoambiental da sub-bacia do rio Capivari-Mirim (título provisório). (Mestrado em andamento). Escola de Engenharia de São Carlos - Universidade de São Paulo.

SOUSA, A. A. (2000). Tratamento digital de fotografias aéreas verticais como uma alternativa à análise estereoscópia de bacias hidrográficas. Piracicaba. 167p. Tese (Doutorado). Escola Superior de Agronomia Luiz de Queiroz Universidade de São Paulo.

STATSOFT Ins. (2000). Programa Statistica ${ }^{\circledR}$, versão 5.5. Tulsa, OK - USA.

STRAHLER, A. N. (1957). Quantitative analysis of watershed geomorphology. Transaction of the American Goeophysical Union. v. 38, n.6, p. 913-920.

TAVARES, A.C.; QUEIROZ, A.N. (1981). Análise geomorfológica da bacia do Ribeirão Claro. Rio Claro. Boletim de Geografia Teorética. v. 11, n.21-22, p.47-64.

TOMMASI, L.R. (1994). Estudo de impacto ambiental. São Paulo, CETESB: terragraph artes e informática. $354 \mathrm{p}$. 
UNESP - Universidade Estadual Paulista - (1986). Mapa Geológico: Jundiaí, Folha SF-23-Y-C-III-1. Rio Claro, UNESP. Escala 1:50.000.

VILLALBA, M; ROSA, F.J.B; RODRIGUEZ, M.T.; SÁNCHEZ, J.C.J. (1995). Hydrochemical study of an aquifer system in an agricultural area in South West Spain. Water Research, v29, n.5, p.1361-1372.

VILLELA, S. M.; MATTOS, A. (1980). Hidrologia aplicada. São Paulo. McGraw-Hill do Brasil.

WEISS, N. A.; HASSETT, J. (1991). Introductory Statistics. 3 ed. Addison - Wesley Publishing Company.

WERNICK, E (1978). Contribuição à estratigrafia do Pré-cambriano do leste do Estado de São paulo e áreas vizinhas. Revista Brasileira de Geociências, São Paulo, v.3,n.8,p.206-216.

WOOD-SMITH, R. D.; BUFFINGTON, J. M. (1996). Multivariate geomorphic analysis of forest streams: implications for assessment of land use impacts on channel condition. Earth surface processes and landforms, v.21, p.377-393

WRANIC, A.D.; HROMADKA, T.V; SAINT, P.K. (1994). Pollutant loadings generated by nonpoint sources in the Santa Monica Bay drainage basin: a case study. Water Resources Management, v.8, p.327-343.

YANG, M.; MERRY, C.J.; SYKES, R.M. (1999). Integration of water quality modeling, remote sensing, and GIS. Journal of the American Water Resources Association. v.35, n.2, p. 253-263.

ZUQUETTE, L.V. (1991). Importância dos estudos geológicos geotécnicos para a disposição de rejeitos urbanos. In: SIMPÓSIO SOBRE BARRAGENS DE REJEITO E DISPOSIÇÃO DE RESÍDUOS, 2, Rio de Janeiro, 1991. Anais. Rio de Janeiro - RJ. v.1. p. 367 - 377. 
